\title{
Argonne
}

ANL/EVS-15/1

\section{Reassessment of Floodplain Wetland Connections in the Middle Green River, Utah}

\author{
Environmental Science Division
}

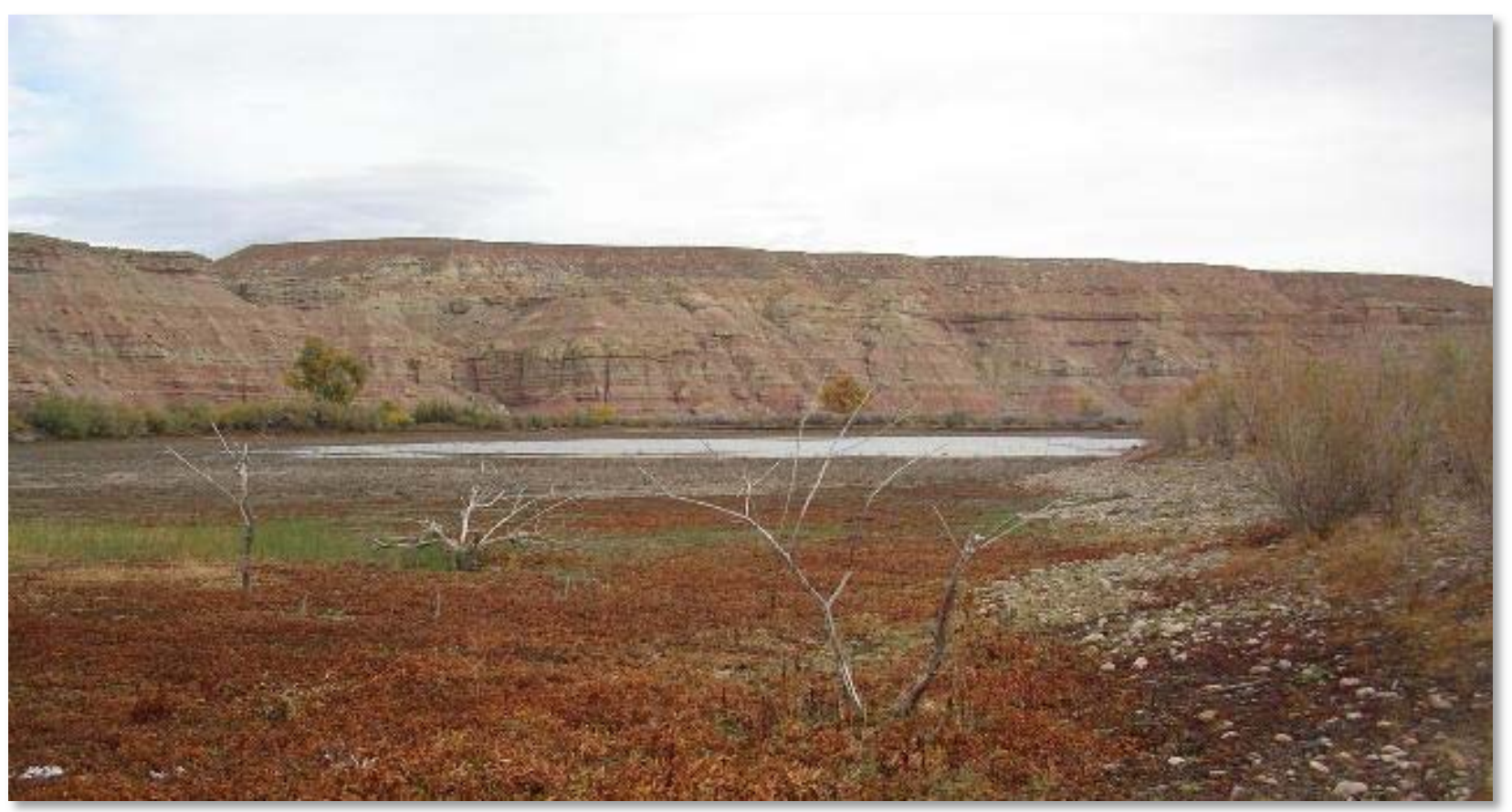




\begin{abstract}
About Argonne National Laboratory
Argonne is a U.S. Department of Energy laboratory managed by UChicago Argonne, LLC under contract DE-AC02-06CH11357. The Laboratory's main facility is outside Chicago, at 9700 South Cass Avenue, Argonne, Illinois 60439. For information about Argonne and its pioneering science and technology programs, see www.anl.gov.
\end{abstract}

\title{
DOCUMENT AVAILABILITY
}

Online Access: U.S. Department of Energy (DOE) reports produced after 1991 and a growing number of pre-1991 documents are available free via DOE's SciTech Connect (http://www.osti.gov/scitech/)

Reports not in digital format may be purchased by the public from the National Technical Information Service (NTIS):

\section{U.S. Department of Commerce}

National Technical Information Service

5301 Shawnee Rd

Alexandra, VA 22312

www.ntis.gov

Phone: (800) 553-NTIS (6847) or (703) 605-6000

Fax: (703) 605-6900

Email: orders@ntis.gov

Reports not in digital format are available to DOE and DOE contractors from the Office of Scientific and Technical Information (OSTI):

U.S. Department of Energy

Office of Scientific and Technical Information

P.O. Box 62

Oak Ridge, TN 37831-0062

www.osti.gov

Phone: (865) 576-8401

Fax: (865) 576-5728

Email: reports@osti.gov

\section{Disclaimer}

This report was prepared as an account of work sponsored by an agency of the United States Government. Neither the United States Government nor any agency thereof, nor UChicago Argonne, LLC, nor any of their employees or officers, makes any warranty, express or implied, or assumes any legal liability or responsibility for the accuracy, completeness, or usefulness of any information, apparatus, product, or process disclosed, or represents that its use would not infringe privately owned rights. Reference herein to any specific commercial product, process, or service by trade name, trademark, manufacturer, or otherwise, does not necessarily constitute or imply its endorsement, recommendation, or favoring by the United States Government or any agency thereof. The views and opinions of document authors expressed herein do not necessarily state or reflect those of the United States Government or any agency thereof, Argonne National Laboratory, or UChicago Argonne, LLC. 
ANL/EVS-15/1

\section{Reassessment of Floodplain Wetland Connections in the Middle Green River, Utah}

prepared by

Kirk E. LaGory, Leroy J. Walston, Jr., and Cory C. Weber

Environmental Science Division, Argonne National Laboratory

prepared for

Upper Colorado River Endangered Fish Recovery Program

December 2016 
This page intentionally left blank. 


\section{CONTENTS}

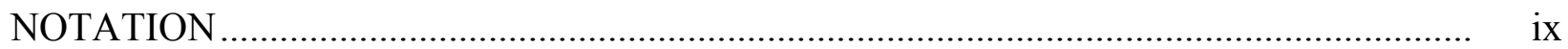

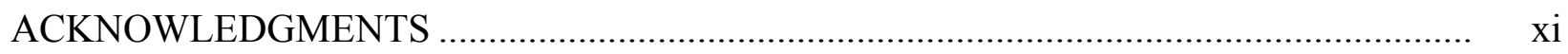

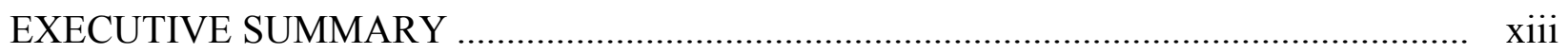

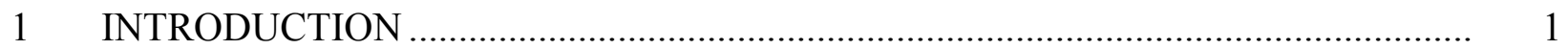

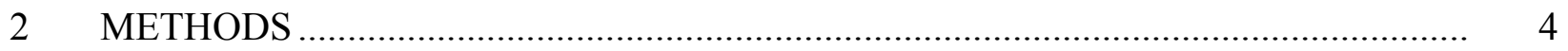

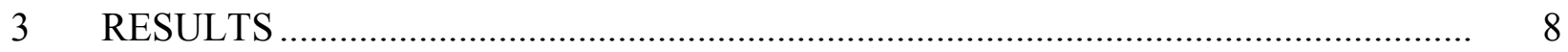

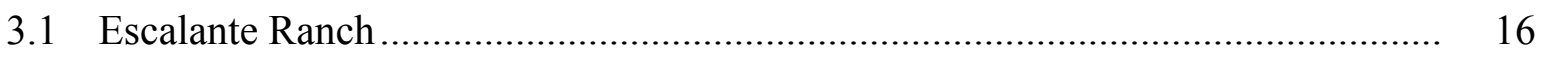

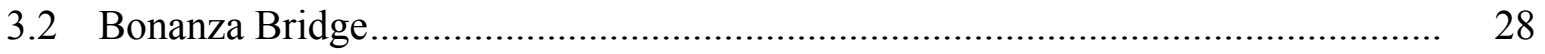

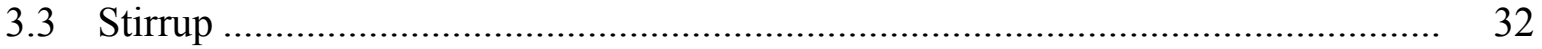

3.4 Above Brennan ....................................................................................... 35

3.5 Johnson Bottom ………………….............................................................. 40

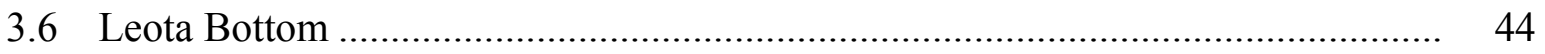

3.7 Sheppard Bottom ………………............................................................. 48

3.8 Old Charlie Wash..................................................................................... 52

3.9 Results Summary ………………............................................................ 56

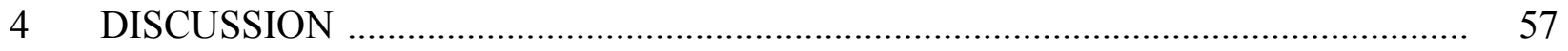

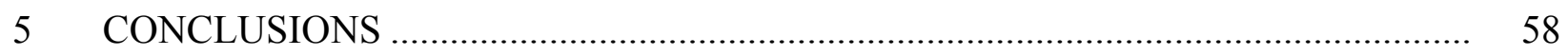

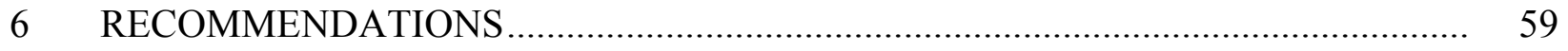

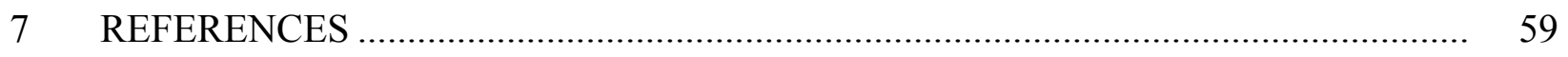

APPENDIX A: USGS Stage-Flow Tables for the Jensen and Ouray Gages ......................... 61

APPENDIX B: Middle Green River Floodplain Wetland Connection Maps for 2012 .......... 81

\section{TABLES}

1 Annual Spring Peak Flow Recommendations for the Green River between the Confluences of the Yampa and White Rivers................................................................ 2

2 Green River Annual Peak Flow at Jensen, Utah, from 2005-2012 ............................. 4 


\section{TABLES (Cont.)}

3 Summary of Survey Dates and Modeled Local Flow Conditions for Eight Floodplain Wetland Sites on the Middle Green River, Utah, in 2012 ...................... 6

$4 \quad$ Breach and Connection Flows at Surveyed Breaches in October 2012 and Comparison to Previously Reported Connection Flows

$5 \quad$ Minimum Connection Flows at Floodplain Wetlands in 2005 and 2012 for Any Breach, Upstream Breaches Only, and Downstream Breaches Only ....

6 Fish Passage Flows at Surveyed Breaches in October 2012 and Comparison to Estimated 2005 Fish Passage Flows

A-1 USGS Stage-Flow Table for the Jensen Gage (USGS 09261000) in 2005 and 2012 ..

A-2 USGS Stage-Flow Table for the Ouray Gage (USGS 9272400) in 2012

\section{FIGURES}

12012 Green River Floodplain Wetland Survey Locations, October $2012 \ldots \ldots \ldots \ldots \ldots \ldots \ldots$

2012 Floodplain Wetland Survey Photographs ............................................... 7

$3 \quad$ Escalante Ranch Survey Locations................................................................ 17

$4 \quad$ ER-IN-1 Survey Locations. ........................................................................ 18

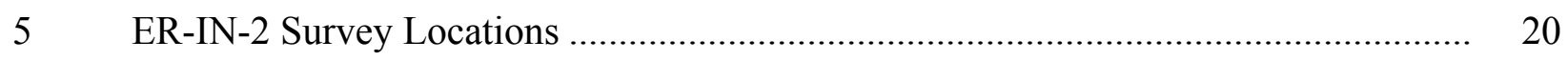

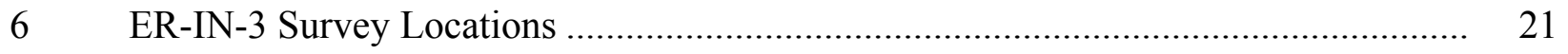

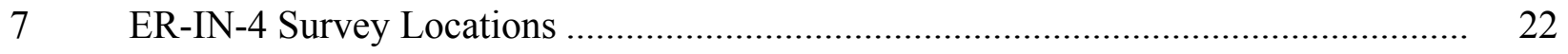

$8 \quad$ ER-IN-5 Survey Locations ..................................................................... 23

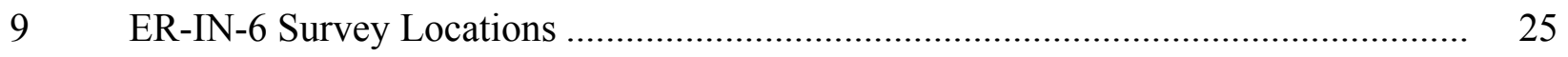

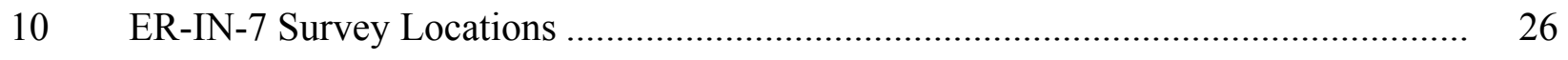

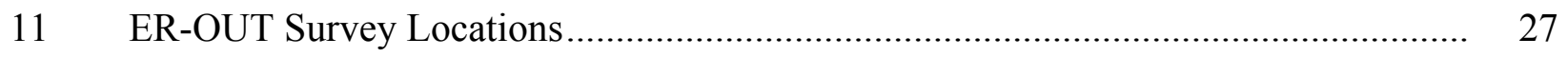

12 Bonanza Bridge Survey Locations................................................................. 29 


\section{FIGURES (Cont.)}

13 BB-IN-1 Survey Locations ............................................................................ $\quad 30$

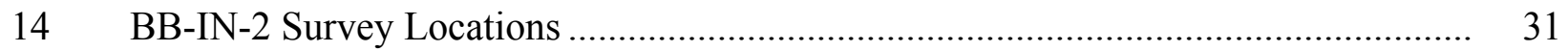

15 BB-IN-3 Breach Survey Locations ....................................................................... 33

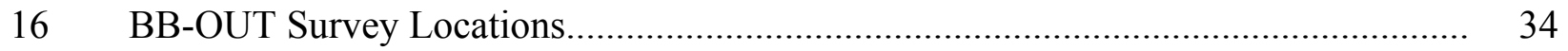

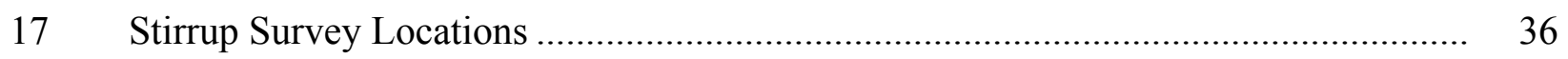

18 Above Brennan Survey Locations ....................................................................... 37

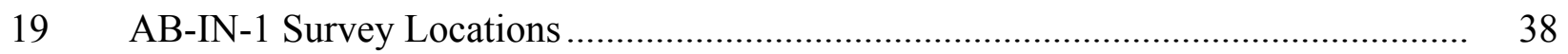

20 AB-IN-2 Survey Locations ………………..................................................... 39

21 AB-IN-3 Survey Locations ............................................................................ 41

22 AB-OUT Survey Locations ............................................................................. 42

23 Johnson Bottom Survey Locations …………….................................................. 43

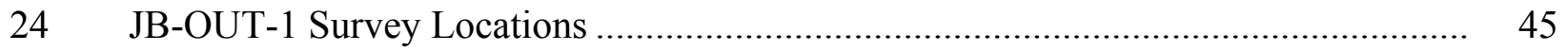

25 JB-OUT-2 Survey Locations ………………................................................. 46

26 Leota Bottom Survey Locations ………………................................................... 47

27 LB7-IN Survey Locations ............................................................................... 49

$28 \quad$ LB7A-IN Survey Locations .............................................................................. 50

29 Sheppard Bottom Survey Locations ………........................................................ 51

$30 \quad$ Old Charlie Wash Survey Locations....................................................................... 53

31 OC-OUT-1 Survey Locations ………………................................................. 54

32 OC-OUT-2 Survey Locations ……………….................................................... 55

B-1 Floodplain Wetland Connection Channel and Minimum Connection Cross Section

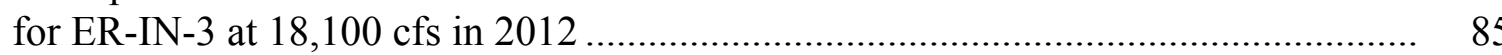




\section{FIGURES (Cont.)}

B-2 Floodplain Wetland Connection Channel and Minimum Connection Cross Section for ER-IN-4 at 20,300 cfs in 2012

B-3 Floodplain Wetland Connection Channel and Minimum Connection Cross Section for ER-IN-5 at $16,800 \mathrm{cfs}$ in 2012

B-4 Floodplain Wetland Connection Channel and Minimum Connection Cross Section for ER-IN-6 at 19,200 cfs in 2012 .

B-5 Floodplain Wetland Connection Channel and Minimum Connection Cross Section for ER-IN-7 at 15,300 cfs in 2012

B-6 Floodplain Wetland Connection Channel and Minimum Connection Cross Section for ER-OUT at $11,300 \mathrm{cfs}$ in 2012

B-7 Floodplain Wetland Connection Channel and Minimum Connection Cross Section for BB-IN-1 at 20,100 cfs in 2012

B-8 Floodplain Wetland Connection Channel and Minimum Connection Cross Section for BB-IN-2 at 21,100 cfs in 2012 .

B-9 Floodplain Wetland Connection Channel and Minimum Connection Cross Section for BB-IN-3 at 24,100 cfs in 2012

B-10 Floodplain Wetland Connection Channel and Minimum Connection Cross Section for BB-OUT at $17,400 \mathrm{cfs}$ in 2012

B-11 Floodplain Wetland Connection Channel and Minimum Connection Cross Section for ST-OUT at $16,900 \mathrm{cfs}$ in 2012

B-12 Floodplain Wetland Connection Channel and Minimum Connection Cross Section for AB-IN-1 at 16,400 cfs in 2012

B-13 Floodplain Wetland Connection Channel and Minimum Connection Cross Section for AB-IN-2 at 19,500 cfs in 2012

B-14 Floodplain Wetland Connection Channel and Minimum Connection Cross Section for AB-IN-3 at 18,500 cfs in 2012 .

B-15 Floodplain Wetland Connection Channel and Minimum Connection Cross Section for AB-OUT at 9,990 cfs in 2012 


\section{FIGURES (Cont.)}

B-16 Floodplain Wetland Connection Channel and Minimum Connection Cross Section

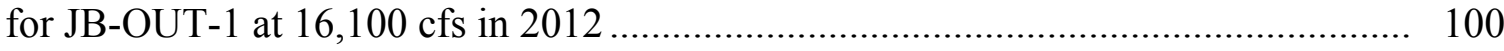

B-17 Floodplain Wetland Connection Channel and Minimum Connection Cross Section

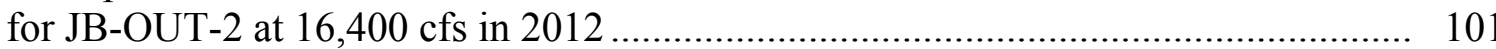

B-18 Floodplain Wetland Connection Channel and Minimum Connection Cross Section for LB7-IN at 17,600 cfs in 2012 .................................................................. 102

B-19 Floodplain Wetland Connection Channel and Minimum Connection Cross Section

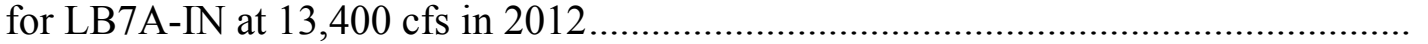

B-20 Floodplain Wetland Connection Channel and Minimum Connection Cross Section for OC-OUT-1 at $14,300 \mathrm{cfs}$ in 2012 .

B-21 Floodplain Wetland Connection Channel and Minimum Connection Cross Section for OC-OUT-2 at 9,430 cfs in 2012 
This page intentionally left blank. 


\section{NOTATION}

\section{ACRONYMS, INITIALISMS, AND ABBREVIATIONS}

$\begin{array}{ll}\text { Argonne } & \text { Argonne National Laboratory } \\ \text { Reclamation } & \text { Bureau of Reclamation } \\ \text { Recovery Program } & \text { Upper Colorado River Endangered Fish Recovery Program } \\ \text { USGS } & \text { U.S. Geological Survey } \\ \text { WAPA } & \text { Western Area Power Administration }\end{array}$

\section{UNITS OF MEASURE}

cfs cubic foot (feet) per second

$\mathrm{cm}$ centimeter(s)

$\mathrm{ft} \quad$ foot/feet

h hour(s)

km kilometers(s)

mi mile(s)

$\mathrm{m}^{3} \quad$ cubic meter(s)

s second(s)

\section{METRIC UNIT CONVERSIONS}

$\begin{array}{ll}1 \mathrm{cfs} & 0.0283 \mathrm{~m}^{3} / \mathrm{s} \\ 1 \mathrm{ft} & 30 \mathrm{~cm} \\ 1 \mathrm{mi} & 1.61 \mathrm{~km} \\ 1 \text { river mi } & 1.61 \text { river } \mathrm{km}\end{array}$


This page intentionally left blank. 


\section{ACKNOWLEDGMENTS}

This project was funded by the Western Area Power Administration (WAPA) Colorado River Storage Project Management Center under contract DE-AC02-06CH11357. We thank Scott Schlueter (Argonne National Laboratory [Argonne]), Judd Hopkins (WAPA), Jerry Wilhite (WAPA), and Tildon Jones (U.S. Fish and Wildlife Service) for assistance in collecting field data. Dan Shaad (Refuge Manager for the Ouray National Wildlife Refuge) provided logistics information for our survey work. John Hayse, David Waterman, and Andy Orr of Argonne provided helpful suggestions for our analysis. 
This page intentionally left blank. 


\section{EXECUTIVE SUMMARY}

The frequency, magnitude, and duration of seasonal overbank flooding in the Green River have been substantially reduced since closure of Flaming Gorge Dam. Flow recommendations (Muth et al. 2000) were developed to assist with conservation and recovery of endangered fish species in the Green River downstream from Flaming Gorge Dam. Among the objectives of these recommendations was to provide for floodplain wetland connection to the river at sufficient frequency and duration to support sustained recruitment of the endangered razorback sucker (Xyrauchen texanus). Although floodplain habitats are important for all four of the endangered Colorado River fishes, the inundation of floodplain wetlands along the middle Green River is particularly important for providing important nursery habitat for young-of-theyear razorback suckers. Restoring or enhancing floodplain wetland connections to the river would provide access to these productive habitats and is expected to support the recovery of the four endangered fish species in the basin.

An uncertainty identified in the Larval Trigger Study Plan (Larval Trigger Study Plan Ad Hoc Committee 2012), a report that identified priorities for geomorphology research in the Upper Colorado River Basin (LaGory et al. 2003), and in the Green River Study Plan (Green River Study Plan Ad Hoc Committee 2007) was interannual variability in the flow needed to connect floodplain wetlands, and the effect of peak flows on these connecting flows. The present study was developed to address this uncertainty.

This report presents the results of floodplain wetland connection surveys conducted in 2012 at eight priority floodplain wetlands along the middle Green River between Jensen and Ouray, Utah. Surveys were conducted at levee breaches and within channels leading from the breaches to the wetlands (referred to here as connection channels) to characterize the flows needed to connect the river's main channel with the floodplain wetlands. Specific objectives of this work were to:

- Determine the minimum flow that would connect floodplain wetlands to the main channel river and allow for the entrainment of larval razorback suckers;

- Determine the minimum flow that would allow the passage of subadult and adult razorback suckers (minimum depth of $1 \mathrm{ft}[30 \mathrm{~cm}]$ based on Burdick 1997) between the wetlands and the river; and

- Compare our 2012 survey results with previously reported results from Tetra Tech (2005) and Bestgen et al. (2011) to determine if and how conditions have changed since 2005 . 
Our survey results will be used in conjunction with the results of other studies conducted under the Larval Trigger Study Plan and Green River Study Plan plans to resolve uncertainties associated with razorback sucker floodplain nursery habitats and factors contributing to recruitment of this species. The evaluation summarized here also will provide important input to the Upper Colorado River Endangered Fish Recovery Program's ongoing evaluation of the Muth et al. (2000) flow recommendations.

Topographic surveys to determine the flows that would connect the main channel of the Green River to eight priority floodplain wetlands were conducted along the middle Green River from October 22 through 25, 2012, between the U.S. Geological Survey (USGS) Jensen gage (USGS 09261000) and the USGS Ouray gage (USGS 9272400). At each wetland location, topographic surveys were conducted of the river surface elevation and at cross sections at the breaches and along the connection channels. This topographic information was used with current USGS stage-discharge relationships to determine minimum flows needed to overtop breaches and connect the floodplain wetlands to the river main channel.

Our 2012 survey identified substantial changes since 2005 at most of the levee breaches and connection channels evaluated. The most recent reported values represented conditions in 2005 (Tetra Tech 2005 and Bestgen et al. 2011), and these values were mostly based on the design specifications of levee breaches made to intentionally entrain water at specific high flows.

The average minimum floodplain connection flow (i.e., the lowest connecting breach) among the seven floodplains surveyed in 2012 was $13,503 \mathrm{cfs}$. This is a relatively small mean increase ( $826 \mathrm{cfs}$ ) compared to estimated connection flows in 2005 . However, there was considerable variation among the wetlands in estimated minimum connection flow, ranging from 9,430 cfs at Old Charlie Wash to 17,400 cfs at Bonanza Bridge. There was much less variation in estimated minimum connection flow in 2005 (11,166 to 13,000 cfs).

Changes in connection flows differed between upstream and downstream breaches with upstream breaches showing a much larger increase since 2005 compared to downstream breaches. The mean connection flow of upstream breaches in 2012 was $17,267 \mathrm{cfs}(15,300$ to $20,100 \mathrm{cfs})$ compared to $12,389 \mathrm{cfs}(11,166$ to $13,000 \mathrm{cfs})$ in 2005, and represents an increase of $4,878 \mathrm{cfs}(3,400$ to $7,100 \mathrm{cfs})$ for upstream breaches. The mean connection flow of downstream breaches in 2012 was $13,503 \mathrm{cfs}(9,430$ to $17,400 \mathrm{cfs})$ compared to the 2005 mean of 13,056 cfs $(12,433$ to $13,900 \mathrm{cfs})$, and represents an increase of $465 \mathrm{cfs}(-3,570$ to $+3,900 \mathrm{cfs})$ for downstream breaches.

Estimated fish passage flows in 2012 were approximately 2,300 to 2,600 cfs higher than connection flows in the Ouray National Wildlife Refuge wetlands (Johnson Bottom, Leota Bottom, and Old Charlie Wash) and 3,300 to 3,600 cfs higher than connection flows in the wetlands further upstream. In 2012, the mean minimum fish passage flow for the floodplain wetlands surveyed was $19,900 \mathrm{cfs}(11,600$ to $27,900 \mathrm{cfs})$. In 2012 , the mean minimum fish passage flow for the floodplain wetlands surveyed (i.e., the lowest of all levee breaches in each wetland) was approximately $16,343 \mathrm{cfs}(11,600$ to $20,800 \mathrm{cfs})$. 
Our results indicate that there is a need for periodic reassessments of levee breaches and connection channels especially following very high peak flows. Changes in estimated floodplain connection flows since 2005 were related to the amount of scour and sediment deposition in levee breaches and the intervening connection channels that connect the wetlands to the river's main channel at high flows. In general, connection flows for upstream breaches increased, and connection flows for downstream breaches decreased since 2005. In the wetlands studied, upstream breaches were topographically higher than the wetland, while downstream breaches were lower than the wetland. This topographic variation results in the deposition and scour patterns we observed.

Downstream breaches also serve as inlets for flood water at lower flows. Water depth in downstream connection channels increase as flows rise until connection with the wetland margin occurs, at which time the wetland begins to fill. Downstream breaches can be depositional areas during this filling process, but when peak flows recede, scour of new deposits would occur as water flows out of the wetland and the wetland water surface stabilizes to a lower elevation.

Our observations support those of Heitmeyer and Fredrickson (2005), who stated that high flows may increase sedimentation and debris build up in upstream breaches, resulting in higher subsequent connection flows in these breaches, but would tend to scour downstream breaches, resulting in maintenance or reduction of connection flows. Our results suggest that for upstream breaches to remain as viable connections to floodplain wetlands over the long term, regular breach and connection channel inspection and maintenance may be required.

We recommend the following:

- Resurvey floodplain wetland breaches and their connection channels following peak flows that exceed previously determined connection flows to determine if those peak flows have altered connection flows.

- Determine connection of floodplain wetlands annually by direct observation. Ideally, determinations would be made of initial connection flows at upstream and downstream breaches and the degree of filling and draining through the peak flow cycle.

- Measure the surface area of floodplain wetlands after peak flows recede and through the summer and winter to determine if floodplain wetlands provide suitable habitat for razorback suckers between flooding events that reconnect the wetlands to the main channel.

- Consider modification of floodplain wetland breaches and connection channels to provide connection to the main channel river at a return frequency of 1.5 years (probability of about $67 \%$ ) to mimic pre-dam flooding frequency. 
- Consider modifications of wetlands to prevent sediment deposition from blocking inflow. These modifications could include (1) actively reconfiguring levee breaches, connection channels, and wetland topography to minimize the blockage of connection channels; (2) filling or allowing the filling of upstream breaches; (3) creating control structures such as those that have been successfully deployed at Stewart Lake, Johnson Bottom, and Old Charlie Wash; and (4) managing vegetation encroachment that exacerbates sediment deposition in breaches and channels. 


\section{INTRODUCTION}

The frequency, magnitude, and duration of seasonal overbank flooding in the Green River have been substantially reduced since closure of Flaming Gorge Dam. Flow recommendations (Muth et al. 2000) were developed to assist with conservation and recovery of endangered fish species in the Green River downstream from Flaming Gorge Dam. These recommendations identified target instantaneous annual spring peak flows in the middle Green River between the confluences of the Yampa River and White River of at least 18,600 cubic feet per second (cfs) (as measured at the Jensen gage) in 1 of 2 years, and flows of at least 18,600 cfs for at least 2 weeks in 4 of 10 years (Table 1). No upper limits were placed on recommended annual spring peak flows in any hydrologic condition. The intent of these recommendations was to provide floodplain wetland connection to the river at sufficient frequency and duration to support sustained recruitment of the endangered razorback sucker (Xyrauchen texanus).

Although floodplain habitats are important for all four of the endangered Colorado River fishes, the inundation of floodplain wetlands along the middle Green River is particularly important for providing important nursery habitat for young-of-the-year razorback suckers. Restoring or enhancing floodplain wetland connections to the river would provide access to these productive habitats and is expected to improve the recovery of the four endangered fish species in the Green River Basin.

In implementing the flow recommendations to achieve recommended peak flow magnitudes and durations prior to 2011, the Bureau of Reclamation (Reclamation) timed the releases of water from Flaming Gorge Reservoir to match the peak flows in the Yampa River in accordance with the Flaming Gorge Dam Environmental Impact Statement Record of Decision (Reclamation 2006). The primary purpose of those spring operations at Flaming Gorge Dam was to provide access to floodplain wetland nursery habitat for young-of-the-year razorback sucker in the middle Green River. Despite Reclamation's success in meeting or exceeding peak-flow magnitudes and durations in the middle Green River since the flow recommendations were published, consistent and substantial razorback sucker recruitment had not been observed.

In a recently completed synthesis report (Bestgen et al. 2011), researchers concluded that in most years since 1993, releases from Flaming Gorge Dam occurred too early relative to the presence of drifting razorback sucker larvae in the Green River. The researchers recommended that the Colorado River Endangered Fish Recovery Program (Recovery Program) and Reclamation implement an altered schedule to match the timing of flow releases from Flaming Gorge Dam with the presence of razorback sucker larvae in the middle Green River. The Recovery Program proposed that Reclamation use the occurrence of razorback sucker larvae in channel margin habitats (as determined by real-time monitoring) as the trigger to determine when peak releases from Flaming Gorge Dam should occur. 
TABLE 1 Annual Spring Peak Flow Recommendations for the Green River between the Confluences of the Yampa and White Rivers (Muth et al. 2000) ${ }^{\mathrm{a}}$

\begin{tabular}{|c|c|c|c|c|c|}
\hline & \multicolumn{5}{|c|}{ Hydrologic Condition } \\
\hline & $\begin{array}{c}\text { Wet } \\
(0 \text { to } 10 \% \\
\text { Exceedance) }\end{array}$ & $\begin{array}{c}\text { Moderately Wet } \\
\text { (10 to } 30 \% \\
\text { Exceedance) }\end{array}$ & $\begin{array}{c}\text { Average } \\
\text { (30 to } 70 \% \\
\text { Exceedance) }\end{array}$ & $\begin{array}{c}\text { Moderately } \\
\text { Dry } \\
\text { (70 to } 90 \% \\
\text { Exceedance) } \\
\end{array}$ & $\begin{array}{c}\text { Dry } \\
\text { (90 to } 100 \% \\
\text { Exceedance) }\end{array}$ \\
\hline $\begin{array}{l}\text { Peak-flow } \\
\text { magnitude }\end{array}$ & $\geq 26,400 \mathrm{cfs}$ & $\geq 20,300 \mathrm{cfs}$ & $\begin{array}{l}\geq 18,600 \text { cfs in } 1 \text { of } \\
2 \text { average years; } \\
\geq 8,300 \text { cfs in other } \\
\text { average years }\end{array}$ & $\geq 8$, & $0 \mathrm{cfs}$ \\
\hline $\begin{array}{l}\text { Peak-flow } \\
\text { duration }\end{array}$ & $\begin{array}{l}\text { Flows }>22,700 \\
\text { cfs should be } \\
\text { maintained for } \\
2 \text { weeks or more, } \\
\text { and flows } \\
>18,600 \text { cfs for } \\
4 \text { weeks or more }\end{array}$ & $\begin{array}{l}\text { Flows }>18,600 \\
\text { cfs should be } \\
\text { maintained for } \\
2 \text { weeks or more }\end{array}$ & $\begin{array}{l}\text { Flows }>18,600 \text { cfs } \\
\text { should be } \\
\text { maintained for at } \\
\text { least } 2 \text { weeks in at } \\
\text { least } 1 \text { of } 4 \\
\text { average years }\end{array}$ & $\begin{array}{l}\text { Flows }>8,300 \\
\text { cfs should be } \\
\text { maintained for } \\
\text { at least } 1 \text { week }\end{array}$ & $\begin{array}{l}\text { Flows }>8,300 \\
\text { cfs should be } \\
\text { maintained for } \\
2 \text { days or more, } \\
\text { except in } \\
\text { extremely dry } \\
\text { years ( } \geq 98 \% \\
\text { exceedance) }\end{array}$ \\
\hline
\end{tabular}

a All flow targets are as measured at the Jensen, Utah, gage (USGS 09261000).

Determining the effectiveness of this larval trigger in promoting the recruitment of razorback suckers is the primary focus of a study plan developed by the Larval Trigger Study Plan Ad Hoc Committee (2012) (referred to here as the "Larval Trigger Study Plan"). One uncertainty identified in the Larval Trigger Study Plan, a report that identified priorities for geomorphology research in the Upper Colorado River Basin (LaGory et al. 2003), and the Green River Study Plan (Green River Study Plan Ad Hoc Committee 2007) was inter-annual variability in the flow needed to connect floodplain wetlands and the effect of peak flows on these connecting flows. As noted in the Larval Trigger Study Plan:

A new field study would be needed to collect these data, but could tier from ongoing project C6-hydro to assess actual connection flow (i.e., when river flow begins to enter wetlands) at each study wetland at the beginning of the study, and perhaps every year thereafter until study completion. It may be necessary to develop new river flow and entrainment relationships at the beginning of the study, and periodically during the study, if breach elevations are altered by annual high flows. Green River researchers have noted the poor concordance between published (i.e., Valdez and Nelson 2004; Bestgen et al. 2011) connecting flows and actual connecting flows following high-flow years. These differences 
between actual and published connecting flows may be especially noticeable following the very high flows in $2011 .^{1}$

The present study was developed to address this uncertainty. Surveys were conducted at eight priority floodplain wetland sites along the middle Green River between Jensen and Ouray, Utah, at levee breaches and within channels leading from the breaches to the wetlands (referred to here as connection channels) to characterize the flows needed to connect the river's main channel with the floodplain wetlands. Specific objectives of this work were to:

- Determine the minimum flow that would connect floodplain wetlands to the main channel river and allow for the entrainment of larval razorback suckers;

- Determine the minimum flow that would allow the passage of subadult and adult razorback suckers (minimum depth of $1 \mathrm{ft}[30 \mathrm{~cm}]$ based on Burdick 1997) between the wetlands and the river; and

- Compare our 2012 survey results with previously reported results from Tetra Tech (2005) and Bestgen et al. (2011) ${ }^{2}$ to determine if and how conditions have changed since 2005 .

The annual peak flows at the Green River Jensen gage since 2005 are shown in Table 2. In three years $(2008,2010$, and 2011), annual peak flows were higher than the flows that occurred in 2005, and, thus, had the potential to either scour sediment deposited in levee breaches and connection channels in 2005 or deposit more sediment in those areas.

Our survey results will be used in conjunction with the results of other studies conducted under the Larval Trigger Study Plan and Green River Study Plan to resolve uncertainties associated with razorback sucker floodplain nursery habitats and factors contributing to recruitment of this species. The evaluation summarized here also will provide important input to the Upper Colorado River Endangered Fish Recovery Program's ongoing evaluation of the Muth et al. (2000) flow recommendations.

1 In 2011, flows were $>18,000$ cfs from May 16 to July 12 (58 days). The maximum mean daily flow of 32,200 cfs was reached on June 11. These high flows resulted in widespread inundation of floodplain wetlands in the middle Green River.

${ }^{2}$ Bestgen (2011) reported connection flows based on several information sources including TetraTech (2005). 


\section{TABLE 2 Green River Annual Peak Flow at Jensen, Utah, from 2005-2012}

\begin{tabular}{cc}
\hline Year & Peak Flow (cfs) \\
\hline 2005 & 19,900 \\
2006 & 19,200 \\
2007 & 12,700 \\
2008 & 24,000 \\
2009 & 19,600 \\
2010 & 20,500 \\
2011 & 32,200 \\
2012 & 10,600 \\
\hline
\end{tabular}

\section{METHODS}

Topographic surveys to determine the flows that would connect the main channel of the Green River to eight priority floodplain wetlands were conducted along the middle Green River from October 22 through 25, 2012, between the U.S. Geological Survey (USGS) Jensen gage (9261000) and the USGS Ouray gage (9272400) (Figure 1). We surveyed a total of 24 levee breach locations at the eight floodplain wetland sites using standard surveying techniques to characterize the topography of the area between the river edge and the floodplain wetland including the full width of the levee breach, adjacent portions of the levee, and the connecting channel from the breach to the wetland. A survey base station was setup at a permanent USGS or Bureau of Land Management (BLM) benchmark with known longitude, latitude, and elevation values. Global Positioning System (GPS) rover units were used (various TopCon digital UHF units including Models $\mathrm{Ga} / \mathrm{Gb}$, Hyper II, and Hyper Vs) communicated with the base station to determine the coordinates of survey points with $\pm 1 \mathrm{~cm}$ horizontal and vertical accuracy. Example photographs of the surveying locations and effort are shown in Figure 2.

The river water surface elevation near each levee breach was surveyed and used to determine the elevation associated with the specific flow at the time of the survey. A summary of survey times and flow conditions at each of the floodplain areas is provided in Table 3 . Local flow conditions were estimated from USGS gage data using calculated flow travel times (lagadjusted flows) and distance from the nearest Green River USGS gage sites (Jensen or Ouray; Table 3). For sites closer to the Jensen gage and downstream from the Ashley Creek confluence, Ashley Creek flows (USGS gage 9266500) were added to Jensen flows to determine flow at the site. Flows were relatively steady during the survey period. Jensen flow ranged from 1,160 to 1,220 cfs; Ashley Creek flow ranged from 20 to $25 \mathrm{cfs}$; and Ouray flow ranged from 1,120 to $1,300 \mathrm{cfs}$. 


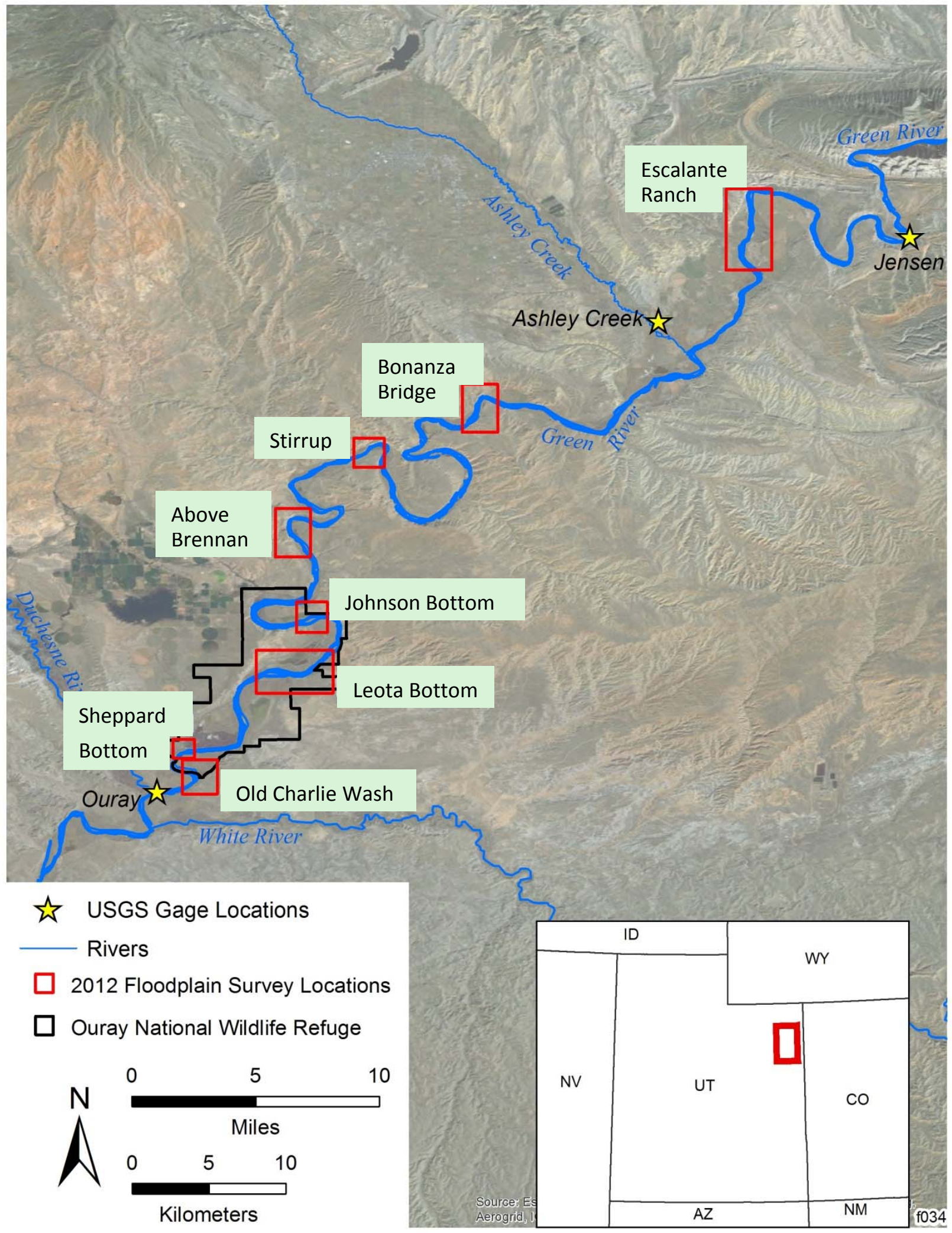

FIGURE 1 Green River Floodplain Wetland Survey Locations, October 2012. Note that Escalante Ranch was referred to as Thunder Ranch in many previous reports. 
TABLE 3 Summary of Survey Dates and Modeled Local Flow Conditions for Eight Floodplain Wetland Sites on the Middle Green River, Utah, in 2012

\begin{tabular}{|c|c|c|c|c|c|c|c|}
\hline $\begin{array}{c}\text { Floodplain } \\
\text { Wetland }\end{array}$ & Date & $\begin{array}{l}\text { Time } \\
\text { (h) }\end{array}$ & $\begin{array}{l}\text { USGS Gage } \\
\text { (distance, } \\
\text { mi }^{\mathrm{a}}\end{array}$ & $\begin{array}{c}\text { Lag- } \\
\text { Adjusted } \\
\text { Gage } \\
\text { Flow } \\
\text { (cfs) }^{\mathrm{b}} \\
\end{array}$ & $\begin{array}{l}\text { Ashley } \\
\text { Creek } \\
\text { Flow } \\
(\mathrm{cfs}) \\
\end{array}$ & $\begin{array}{l}\text { Estimated } \\
\text { Local } \\
\text { Flow } \\
(\mathrm{cfs})^{\mathrm{c}}\end{array}$ & $\begin{array}{c}\text { Estimated } \\
\text { Local } \\
\text { Stage } \\
(\mathrm{ft})^{\mathrm{d}}\end{array}$ \\
\hline Escalante Ranch & $\begin{array}{r}\text { October } \\
23,2012\end{array}$ & $16: 00$ & Jensen (10) & 1,190 & $\mathrm{NA}^{\mathrm{e}}$ & 1,190 & 1.98 \\
\hline Bonanza Bridge & $\begin{array}{c}\text { October } \\
25,2012\end{array}$ & $10: 45$ & Jensen (24) & 1,210 & 25 & 1,235 & 2.03 \\
\hline Stirrup & $\begin{array}{c}\text { October } \\
22,2012\end{array}$ & $12: 00$ & Jensen (38) & 1,170 & 23 & 1,193 & 1.98 \\
\hline Above Brennan & $\begin{array}{c}\text { October } \\
22,2012\end{array}$ & $14: 30$ & Jensen (44) & 1,160 & 20 & 1,180 & 1.97 \\
\hline Johnson Bottom & $\begin{array}{c}\text { October } \\
25,2012\end{array}$ & $13: 45$ & Ouray (-12) & 1,250 & $\mathrm{NA}^{\mathrm{f}}$ & 1,250 & 15.24 \\
\hline Leota Bottom & $\begin{array}{c}\text { October } \\
23,2012\end{array}$ & 11:00 & Ouray (-9) & 1,190 & $\mathrm{NA}^{\mathrm{f}}$ & 1,190 & 15.18 \\
\hline Sheppard Bottom & $\begin{array}{c}\text { October } \\
24,2012\end{array}$ & $13: 50$ & Ouray $(-3)$ & 1,190 & $N^{f}$ & 1,190 & 15.18 \\
\hline Old Charlie Wash & $\begin{array}{l}\text { October } \\
24,2012\end{array}$ & $11: 00$ & Ouray (-1) & 1,190 & $\mathrm{NA}^{\mathrm{f}}$ & 1,190 & 15.18 \\
\hline
\end{tabular}

a Values in parentheses indicate distance (mi) away from the nearest USGS stream gage. Positive values are locations downstream from the gage; negative values are locations upstream from the nearest gage.

b The lag-adjusted flow was determined by offsetting the gage flow by the lag time from the gage to the site. The lag time (hours $[h]$ ) was calculated as $h=8.9441 \times D_{w} \times Q_{\max }{ }^{-0.3231}$, where $D_{\mathrm{w}}$ is the distance (mi) of the wetland from the nearest gage and $\mathrm{Q}_{\max }$ is the maximum hourly flow (cfs) at the gage on the day of the survey.

c For sites associated with the Jensen gage, the local lag-adjusted flow was determined by adding the lagadjusted Jensen flow (column 5) with the Ashley Creek flow (column 6).

d The local lag-adjusted stage was determined using the stage-flow tables provided by the USGS for the Jensen and Ouray gages. Stage-flow tables are provided in Appendix A. Since the stage-flow tables provide discrete values, the closest associated stage value was identified for each flow.

e $\quad \mathrm{NA}=$ not applicable; Ashley Creek is downstream of the Escalante Ranch site and its flow is already included in the Ouray gage flow.

f $\mathrm{NA}=$ not applicable; Ashley Creek flow is included in the Ouray gage flow. 


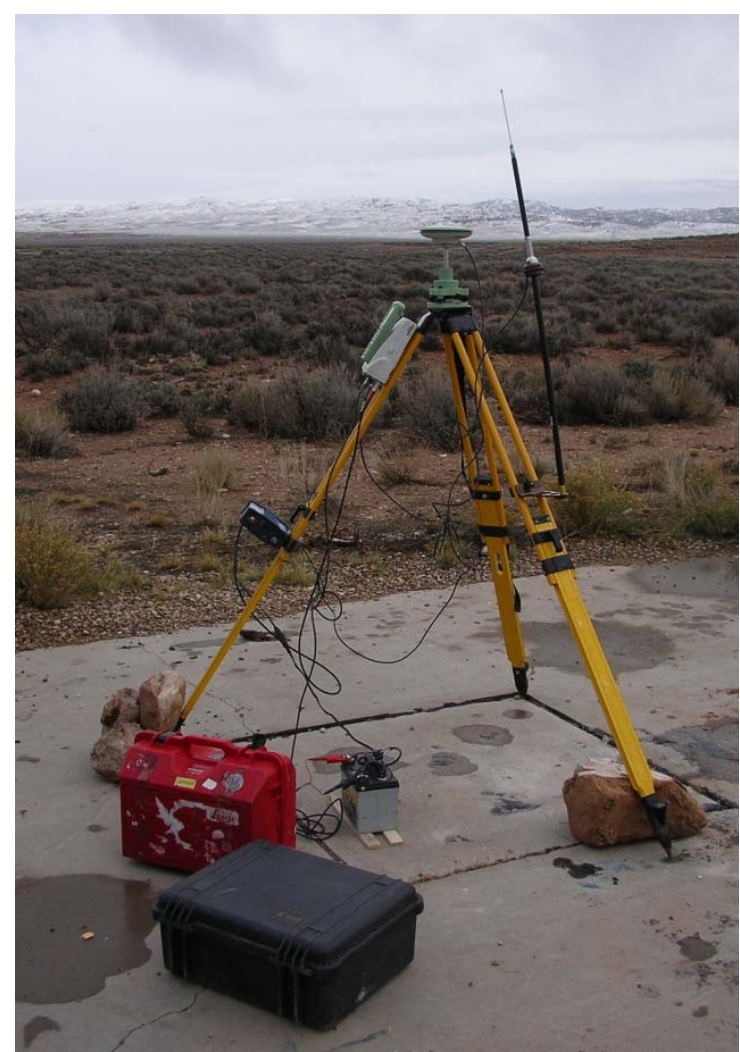

Survey base station equipment

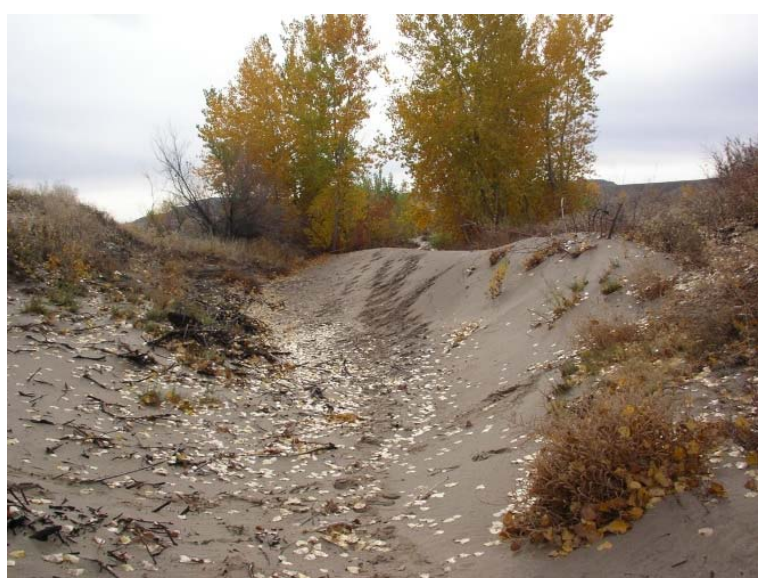

Levee breach at Bonanza Bridge (BB-IN-2) with large deposit of sand obstructing connection channel

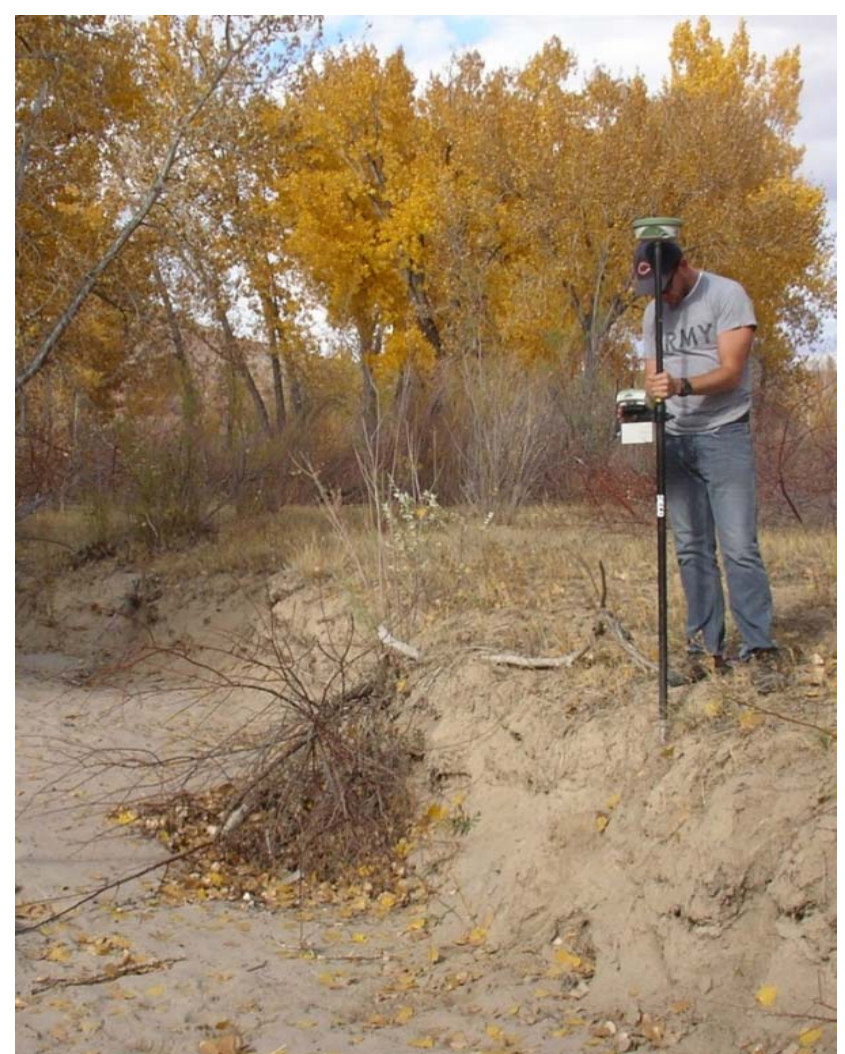

Surveying connection channel with GPS rover at Above Brennan (AB-IN-1)

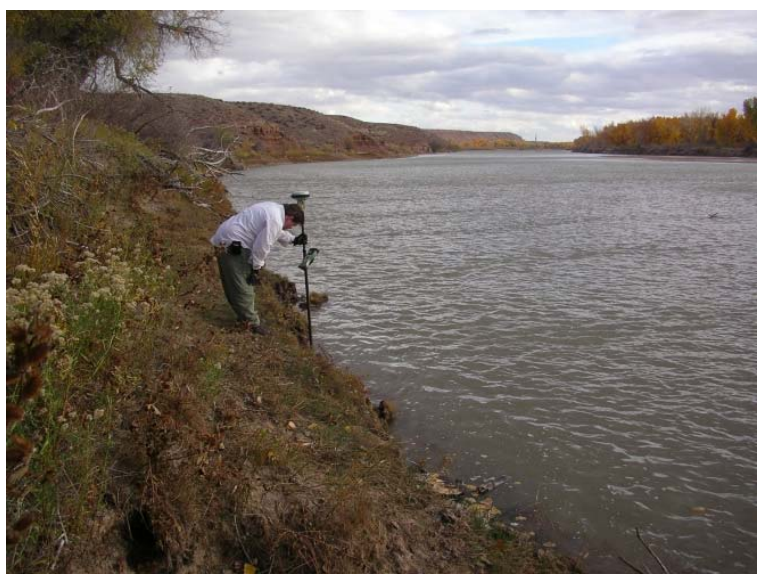

Surveying water's edge and river surface elevation at Above Brennan (AB-OUT)

FIGURE 22012 Floodplain Wetland Survey Photographs 
Flow values corresponding to the elevation of all survey points were determined based on their elevation relative to the river elevation and flow at the time of survey and stage-flow tables provided by USGS for the nearest USGS gage (Jensen or Ouray gage). Stage-flow tables for each of the gages are provided in Appendix A. For wetlands closer to the Jensen gage and downstream of the Ashley Creek confluence, Ashley Creek flows (USGS 9266500) were added to Jensen flows to determine flow at the site. Flows were relatively steady during the survey period. Jensen flow ranged from 1,160 and 1,210 cfs; Ashley Creek flows were approximately $23 \mathrm{cfs}$; and Ouray flows ranged from 1,190 and 2,250 cfs.

Cross sectional transects of levee breaches and connection channels were used to capture all features that could affect the conveyance of water between the river and the wetland, focusing on areas of noticeable elevation change, such as shorelines, sandbars, levee breaches, sand deposits within levee breaches and connecting channels, roads that crossed connecting channels, and scoured areas within breaches and connecting channels. Using the survey data, a topographical surface was spatially interpolated for each location and a spatial model was developed to determine the minimum flow that would provide connection between the river and floodplain wetland. Fish passage flows (i.e., the minimum depth needed for passage of subadult and adult razorback suckers estimated by Burdick [1997] as $1 \mathrm{ft}$ [30 cm]) have not been previously reported for Green River floodplain wetland breaches. These values were estimated starting with the elevations associated with the estimated connection flow, adding $1 \mathrm{ft}$ to those elevations, and determining the associated flow in the stage-flow tables provided by the USGS.

Connection channel surveys were conducted at all but three levee breach locations: Escalante Ranch Inlet 1 (ER-IN-1), Escalante Ranch Inlet 2 (ER-IN-2), and Sheppard Bottom Inlet (SB-IN). After 2005, the two Escalante Ranch breaches had been purposely filled with riprap to prevent connection. The breach location at the Sheppard Bottom site was adjacent to the wetland edge and did not possess a connecting channel. However, the breach was not adjacent to the river and the flow path between the river and breach was not determined. This prevented us from being able to determine the flows that would inundate the Sheppard Bottom wetland.

At each floodplain wetland, the minimum flow needed for connection and fish passage were determined for all breach locations and associated connection channels and compared to floodplain connections reported by Tetra Tech in 2005 (Tetra Tech 2005), if applicable.

\section{RESULTS}

Characteristics of floodplain wetland connections in 2012 and changes since 2005 are provided in this section. Sites are discussed in order of location along the Green River (upstream to downstream) (Figure 1). A summary of survey results, with comparisons to previous reported values (Tetra Tech 2005; Bestgen et al. 2011) is provided in Table 4. Table 5 summarizes minimum connection flows at each floodplain area and at upstream and downstream breaches. Table 6 presents the fish passage flows for each breach in 2005 and 2012. For each levee breach, maps of the connection channel between the river and the floodplain wetland at the minimum connection flow are provided in Appendix B. 
TABLE 4 Breach and Connection Flows at Surveyed Breaches in October 2012 and Comparison to Previously Reported Connection Flows

\begin{tabular}{|c|c|c|c|c|c|c|}
\hline $\begin{array}{l}\text { Floodplain } \\
\text { Wetland }\end{array}$ & $\begin{array}{l}\text { Breach } \\
\text { Name }\end{array}$ & $\begin{array}{l}2012 \text { Breach } \\
\text { Flow (cfs) }\end{array}$ & $\begin{array}{l}2012 \\
\text { Connection } \\
\text { Flow (cfs) }\end{array}$ & $\begin{array}{l}2005 \\
\text { Connection } \\
\text { Flow }(\mathrm{cfs})^{\mathrm{a}}\end{array}$ & $\begin{array}{l}\text { Difference } \\
\text { between } \\
2012 \text { and } \\
2005(\mathrm{cfs})^{\mathrm{b}}\end{array}$ & Notes \\
\hline \multirow[t]{6}{*}{$\begin{array}{l}\text { Escalante } \\
\text { Ranch }\end{array}$} & ER-IN-1 & 22,000 & 22,000 & 11,500 & $+10,500$ & $\begin{array}{l}\text { Prior to the October } 2012 \text { survey, the levee breach was } \\
\text { filled with rip rap to prevent connection to the river. }\end{array}$ \\
\hline & ER-IN-2 & 23,000 & 23,000 & 16,800 & $+6,200$ & $\begin{array}{l}\text { Prior to the October } 2012 \text { survey, the levee breach was } \\
\text { filled with rip rap to prevent connection to the river. }\end{array}$ \\
\hline & ER-IN-3 & 14,500 & 18,100 & 11,900 & $+6,200$ & $\begin{array}{l}\text { Breach was well-defined, but connection flow was higher } \\
\text { than previous values due to deposition of sand and debris in } \\
\text { previous floods. Tetra Tech (2005) noted significant bank } \\
\text { erosion and deposition in the center of the breach, and } \\
\text { inflow at } 14,000 \text { cfs. }\end{array}$ \\
\hline & ER-IN-4 & 17,600 & 20,300 & 12,933 & $+7,367$ & $\begin{array}{l}\text { Connection flow was higher than previous values due to } \\
\text { deposition of sand and debris in previous floods. Tetra Tech } \\
\text { (2005) noted a general trend of deposition, and inflow at } \\
14,000 \text { cfs. }\end{array}$ \\
\hline & ER-IN-5 & 15,200 & 16,800 & 12,000 & $+4,800$ & $\begin{array}{l}\text { Connection flow was higher than previous values due to } \\
\text { deposition of sand and debris in previous floods. Tetra Tech } \\
\text { (2005) noted minor bank erosion and deposition in the } \\
\text { center of the breach, and inflow at } 14,000 \text { cfs. }\end{array}$ \\
\hline & ER-IN-6 & 15,100 & 19,200 & 11,166 & $+8,034$ & $\begin{array}{l}\text { Connection flow was higher than previous values due to } \\
\text { deposition of sand and debris in previous floods. Tetra Tech } \\
\text { (2005) noted a general trend of deposition, and inflow at } \\
14,000 \text { cfs. }\end{array}$ \\
\hline
\end{tabular}


Table 4 (Cont.)

\begin{tabular}{|c|c|c|c|c|c|c|}
\hline $\begin{array}{l}\text { Floodplain } \\
\text { Wetland }\end{array}$ & $\begin{array}{l}\text { Breach } \\
\text { Name }\end{array}$ & $\begin{array}{l}2012 \text { Breach } \\
\text { Flow (cfs) }\end{array}$ & $\begin{array}{l}2012 \\
\text { Connection } \\
\text { Flow (cfs) }\end{array}$ & $\begin{array}{l}2005 \\
\text { Connection } \\
\text { Flow }(\mathrm{cfs})^{\mathrm{a}}\end{array}$ & $\begin{array}{l}\text { Difference } \\
\text { between } \\
2012 \text { and } \\
2005(\mathrm{cfs})^{\mathrm{b}}\end{array}$ & Notes \\
\hline \multirow[t]{2}{*}{$\begin{array}{l}\text { Escalante } \\
\text { Ranch } \\
\text { (cont.) }\end{array}$} & ER-IN-7 & 13,800 & 15,300 & 12,000 & $+3,300$ & $\begin{array}{l}\text { Connection flow was higher than previous values due to } \\
\text { deposition of sand and debris in previous floods. Tetra Tech } \\
(2005) \text { noted a general trend of deposition, and inflow at } \\
14,000 \text { cfs. }\end{array}$ \\
\hline & ER-OUT & 10,800 & 11,300 & 12,433 & $-1,133$ & $\begin{array}{l}\text { Connection flow at this downstream breach was lower than } \\
\text { previous reported values apparently resulting from scour } \\
\text { during previous floods. Tetra Tech ( } 2005) \text { observed some } \\
\text { scouring upstream of the upper control structure, and inflow } \\
\text { at } 14,000 \mathrm{cfs} \text {. }\end{array}$ \\
\hline \multirow[t]{4}{*}{$\begin{array}{l}\text { Bonanza } \\
\text { Bridge }\end{array}$} & BB-IN-1 & 17,400 & 20,100 & $\begin{array}{l}13,000 \\
\text { (actual } \\
>18,500)\end{array}$ & $\begin{array}{l}+7,100 \\
(<+1,600 \\
\text { compared to } \\
\text { actual })\end{array}$ & $\begin{array}{l}\text { Connection flow was similar to previous observed values. } \\
\text { Large deposit of sand where inlet feeds into wetland. Tetra } \\
\text { Tech (2005) stated that the breach elevation is too high for } \\
\text { proper connection at design flows of } 13,000 \mathrm{cfs} \text {, and noted } \\
\text { that the inlet was dry at } 18,500 \mathrm{cfs} \text {, but connected at } \\
19,700 \mathrm{cfs} \text {. }\end{array}$ \\
\hline & BB-IN-2 & 16,300 & 21,100 & $\begin{array}{c}13,000 \\
\text { (actual } \\
>13,900)\end{array}$ & $\begin{array}{l}+8,100 \\
(<+7,200 \\
\text { compared to } \\
\text { actual })\end{array}$ & $\begin{array}{l}\text { Connection flow was higher than previous values. Large } \\
\text { deposit of sand where inlet feeds into wetland. Tetra Tech } \\
\text { (2005) observed some scouring, and noted that connection } \\
\text { was just beginning at } 13,900 \mathrm{cfs} \text {. }\end{array}$ \\
\hline & BB-IN-3 & 24,100 & 24,100 & 13,000 & $+11,100$ & $\begin{array}{l}\text { Connection flow was higher than previous values due to } \\
\text { vegetation growth and deposition of sand and debris in } \\
\text { previous floods. Tetra Tech (2005) observed a thick stand } \\
\text { of Russian olive in breach, and noted measurable inflow at } \\
13,900 \text { cfs. }\end{array}$ \\
\hline & BB-OUT & 13,100 & 17,400 & $\begin{array}{l}13,000 \\
\text { (actual } \\
>13,900)\end{array}$ & $\begin{array}{c}+4,400 \\
(<+3,500 \\
\text { compared to } \\
\text { actual })\end{array}$ & $\begin{array}{l}\text { Connection flow was higher than previous values. Tetra } \\
\text { Tech (2005) noted that BB-OUT was dry at } 13,900 \mathrm{cfs} \text {, but } \\
\text { draining the wetland at } 18,500 \mathrm{cfs} \text {. }\end{array}$ \\
\hline
\end{tabular}


Table 4 (Cont.)

\begin{tabular}{|c|c|c|c|c|c|c|}
\hline $\begin{array}{l}\text { Floodplain } \\
\text { Wetland }\end{array}$ & $\begin{array}{l}\text { Breach } \\
\text { Name }\end{array}$ & $\begin{array}{l}2012 \text { Breach } \\
\text { Flow (cfs) }\end{array}$ & $\begin{array}{l}2012 \\
\text { Connection } \\
\text { Flow (cfs) }\end{array}$ & $\begin{array}{l}2005 \\
\text { Connection } \\
\text { Flow }(\mathrm{cfs})^{\mathrm{a}}\end{array}$ & $\begin{array}{l}\text { Difference } \\
\text { between } \\
2012 \text { and } \\
2005(\mathrm{cfs})^{\mathrm{b}}\end{array}$ & Notes \\
\hline Stirrup & ST-OUT & 11,000 & 16,900 & 13,000 & $+3,900$ & $\begin{array}{l}\text { Connection flow was higher than previous values, although } \\
\text { levee breach elevation was lower than previous reported } \\
\text { values. No deposits of loose sand or debris were noted at } \\
\text { the time of survey. Tetra Tech }(2005) \text { noted filling of the } \\
\text { wetland at } 13,900 \mathrm{cfs} \text {, and a decrease in elevation from } \\
\text { previous surveys of about } 1.5 \mathrm{ft} \text {. }\end{array}$ \\
\hline \multirow[t]{4}{*}{$\begin{array}{l}\text { Above } \\
\text { Brennan }\end{array}$} & AB-IN-1 & 10,300 & 16,400 & 13,000 & $+3,400$ & $\begin{array}{l}\text { Connection flow was higher than previous values, although } \\
\text { levee breach elevation was lower than previous reported } \\
\text { values. Tetra Tech }(2005) \text { noted a general trend in erosion, } \\
\text { and inflow at } 15,000 \mathrm{cfs} \text {. }\end{array}$ \\
\hline & AB-IN-2 & 15,500 & 19,500 & 13,000 & $+6,500$ & $\begin{array}{l}\text { Breach was very narrow, and connection flow was higher } \\
\text { than previous values. Tetra Tech (2005) did not report any } \\
\text { changes at this breach, and noted inflow at } 15,000 \mathrm{cfs} \text {. }\end{array}$ \\
\hline & AB-IN-3 & 16,400 & 18,500 & 13,000 & $+5,500$ & $\begin{array}{l}\text { Connection flow was higher than previous values. Tetra } \\
\text { Tech (2005) noted a general trend of deposition, and inflow } \\
\text { at } 15,000 \mathrm{cfs} \text {. }\end{array}$ \\
\hline & AB-OUT & 9,990 & 9,990 & 13,000 & $-3,010$ & $\begin{array}{l}\text { Connection flow was lower than previously reported values. } \\
\text { Tetra Tech (2005) noted erosion and a decrease in elevation } \\
\text { from previous surveys of about } 1.5 \mathrm{ft} \text {, and inflow at } 15,000 \\
\text { cfs. }\end{array}$ \\
\hline $\begin{array}{l}\text { Johnson } \\
\text { Bottom }\end{array}$ & JB-OUT-1 & 16,100 & 16,100 & $13,000^{\mathrm{c}}$ & $+3,100$ & $\begin{array}{l}\text { Breach and connection channel were not surveyed by Tetra } \\
\text { Tech (2005). Measured connection flow was higher than } \\
\text { value reported by Bestgen et al. (2011). Flow entry is } \\
\text { controlled by gate that is located at the end of a connection } \\
\text { channel. Channel was overgrown with vegetation. }\end{array}$ \\
\hline
\end{tabular}


Table 4 (Cont.)

\begin{tabular}{|c|c|c|c|c|c|c|}
\hline $\begin{array}{l}\text { Floodplain } \\
\text { Wetland }\end{array}$ & $\begin{array}{l}\text { Breach } \\
\text { Name }\end{array}$ & $\begin{array}{l}2012 \text { Breach } \\
\text { Flow (cfs) }\end{array}$ & $\begin{array}{l}2012 \\
\text { Connection } \\
\text { Flow (cfs) }\end{array}$ & $\begin{array}{l}2005 \\
\text { Connection } \\
\text { Flow }(\mathrm{cfs})^{\mathrm{a}}\end{array}$ & $\begin{array}{l}\text { Difference } \\
\text { between } \\
2012 \text { and } \\
2005 \text { (cfs) }^{b}\end{array}$ & Notes \\
\hline $\begin{array}{l}\text { Johnson } \\
\text { Bottom } \\
\text { (cont.) }\end{array}$ & JB-OUT-2 & 11,100 & 16,400 & $13,000^{\mathrm{c}}$ & $+3,400$ & $\begin{array}{l}\text { Connection flow at this wide downstream breach was } \\
\text { higher than the reported value in Bestgen et al. (2011) as a } \\
\text { result of deposition of sand during previous floods. }\end{array}$ \\
\hline $\begin{array}{l}\text { Leota } \\
\text { Bottom }\end{array}$ & LB7-IN & 17,200 & 17,600 & $\mathrm{NA}^{\mathrm{d}}$ & NA & $\begin{array}{l}\text { Large deposits of sand in wide breach. Not reported in } \\
\text { previous surveys. }\end{array}$ \\
\hline & LB7A-IN & 13,300 & 13,400 & NA & NA & Connection flow not reported in previous surveys. \\
\hline $\begin{array}{l}\text { Sheppard } \\
\text { Bottom }^{\mathrm{e}}\end{array}$ & SB-IN & 11,800 & NA & NA & NA & $\begin{array}{l}\text { Broad breach away from river edge. Potential obstructions } \\
\text { to connection between breach and river not determined. } \\
\text { Refuge staff noted that Sheppard Bottom did not connect in } \\
2014 \text { when flows reached } 17,800 \text { cfs at the Ouray gage on } \\
\text { June } 9 \text {. }\end{array}$ \\
\hline \multirow[t]{2}{*}{$\begin{array}{l}\text { Old Charlie } \\
\text { Wash }\end{array}$} & $\begin{array}{l}\text { OC- } \\
\text { OUT-1 }\end{array}$ & 12,400 & 14,300 & $13,000^{\mathrm{c}}$ & $+1,300$ & $\begin{array}{l}\text { Breach and connection channel were not surveyed by Tetra } \\
\text { Tech (2005). No apparent deposition in breach, but } \\
\text { measured connection flow was higher than previous value } \\
\text { reported by Bestgen et al. (2011). }\end{array}$ \\
\hline & $\begin{array}{l}\text { OC- } \\
\text { OUT-2 }\end{array}$ & 3,850 & 9,430 & $13,000^{\mathrm{c}}$ & $-3,570$ & $\begin{array}{l}\text { Breach and connection channel were not surveyed by Tetra } \\
\text { Tech (2005). Measured connection flow was lower than } \\
\text { value reported by Bestgen et al. (2011). Entry to wetland is } \\
\text { controlled by gate. }\end{array}$ \\
\hline $\begin{array}{l}\text { Mean for all } \\
\text { breaches }\end{array}$ & & 14,050 & 16,772 & 13,091 & $+3,815$ & \\
\hline
\end{tabular}


a Values reported in Tetra Tech (2005) except where noted. 2005 connection flows are the flows that were targeted for connection when levee breaches were constructed. Tetra Tech (2005) made observations during the peak runoff period of 2005 to determine if connection was actually occurring at these flows by visiting sites at the following flows: Escalante Ranch: $<10,000 \mathrm{cfs}, 14,000 \mathrm{cfs}, 16,700 \mathrm{cfs}$, and 19,600 cfs; Bonanza Bridge: $<10,000 \mathrm{cfs}$, $13,900 \mathrm{cfs}$, $18,500 \mathrm{cfs}$, and 19,700 cfs; Stirrup: $<10,000 \mathrm{cfs}, 13,900 \mathrm{cfs}, 18,500 \mathrm{cfs}$, and 21,600 cfs; and Above Brennan: $<10,000 \mathrm{cfs}, 15,000 \mathrm{cfs}, 18,300 \mathrm{cfs}$, and $21,800 \mathrm{cfs}$. These visits allowed verification of target flows. In some cases (as noted), actual connection flows were higher than the target.

b Comparisons of 2014 connection flows were made to actual estimates of connection in 2005 as reported in Tetra Tech (2005) where available.

c 2005 connection flow from Bestgen (2011) is presented because connection flow was not presented in Tetra Tech (2005).

d $\quad \mathrm{NA}=$ not available.

e Surveyed breach had been created shortly before survey, and had not been previously surveyed. Connection channel was not identified or surveyed. 
TABLE 5 Minimum Connection Flows at Floodplain Wetlands in 2005 and 2012 for Any Breach, Upstream Breaches Only, and Downstream Breaches Only

\begin{tabular}{|c|c|c|c|}
\hline Floodplain Wetland ${ }^{\mathrm{a}}$ & $\begin{array}{l}2012 \text { Connection } \\
\text { Flow }(\mathrm{cfs})^{\mathrm{b}}\end{array}$ & $\begin{array}{l}2005 \text { Connection Flow } \\
(\mathrm{cfs})^{\mathrm{bc}}\end{array}$ & $\begin{array}{c}\text { Change from } \\
2005 \text { to } 2012 \text { (cfs) }\end{array}$ \\
\hline \multicolumn{4}{|c|}{ Minimum Connection Flows of any Breach } \\
\hline Escalante Ranch & 11,300 (ER-OUT) & 11,166 (ER-IN-6) & +134 \\
\hline Bonanza Bridge & $17,400(\mathrm{BB}-\mathrm{OUT})$ & $13,000(\mathrm{BB}-\mathrm{IN}-3)$ & $+4,400$ \\
\hline Stirrup & $16,900(\mathrm{ST}-\mathrm{OUT})$ & $13,000($ ST-OUT) & $+3,900$ \\
\hline Above Brennan & $9,990(\mathrm{AB}-\mathrm{OUT})$ & 13,000 (all breaches) & $-3,010$ \\
\hline Johnson Bottom & $16,100(\mathrm{JB}-\mathrm{OUT}-1)$ & 13,000 (all breaches) & $+3,100$ \\
\hline Leota Bottom & 13,400 (LB7A-IN) & $\mathrm{NA}^{\mathrm{d}}$ & NA \\
\hline Old Charlie Wash & $9,430($ OC-OUT-2) & 13,000 (all breaches) & $-3,570$ \\
\hline Mean & $13,503(13,520)^{\mathrm{d}}$ & 12,694 & +826 \\
\hline \multicolumn{4}{|c|}{ Minimum Connection Flows of Upstream Breaches } \\
\hline Escalante Ranch & $15,300($ ER-IN-7) & 11,166 (ER-IN-6) & $+4,134$ \\
\hline Bonanza Bridge & 20,100 (BB-IN-1) & $13,000(\mathrm{BB}-\mathrm{IN}-3)$ & $+7,100$ \\
\hline Above Brennan & $16,400(\mathrm{AB}-\mathrm{IN}-1)$ & 13,000 (all breaches) & $+3,400$ \\
\hline Mean & 17,267 & 12,389 & $+4,878$ \\
\hline \multicolumn{4}{|c|}{ Minimum Connection Flows of Downstream Breaches } \\
\hline Escalante Ranch & 11,300 (ER-OUT) & $12,433($ ER-OUT) & $-1,133$ \\
\hline Bonanza Bridge & $17,400(\mathrm{BB}-\mathrm{OUT})$ & $13,900(\mathrm{BB}-\mathrm{OUT})$ & $+3,500$ \\
\hline Stirrup & 16,900 (ST-OUT) & 13,000 (ST-OUT) & $+3,900$ \\
\hline Above Brennan & 9,990 (AB-OUT) & $13,000(\mathrm{AB}-\mathrm{OUT})$ & $-3,010$ \\
\hline Johnson Bottom & $16,100($ JB-OUT-1) & $13,000{\text { (all breaches })^{\mathrm{c}}}$ & $+3,100$ \\
\hline Leota Bottom & 13,400 (LB7A-IN) & NA & NA \\
\hline Old Charlie Wash & $9,430($ OC-OUT-2) & 13,000 (all breaches) & $-3,570$ \\
\hline Mean & $13,503(13,520)^{\mathrm{e}}$ & 13,056 & +465 \\
\hline
\end{tabular}

a Sheppard Bottom was not included in this comparison because connection flow was not determined.

b Breaches associated with connection flows are presented in parentheses.

c 2005 connection flow values are from Tetra Tech (2005) for all wetlands except for Johnson Bottom and Old Charlie Wash, which are from Bestgen et al. (2011). When 2005 target connection flows were known to be incorrect (based on Tetra Tech 2005 observations noted in Table 4), comparisons are made to observed connection flows.

d $\quad$ NA $=$ not available because connection flow in 2005 was not determined.

e Value in parentheses represents the mean of flows without Leota Bottom to enable comparison with the 2005 mean. 
TABLE 6 Fish Passage Flows ${ }^{\mathrm{a}}$ at Surveyed Breaches in October 2012 and Comparison to Estimated 2005 Fish Passage Flows

\begin{tabular}{|c|c|c|c|c|}
\hline $\begin{array}{l}\text { Floodplain } \\
\text { Wetland }^{\mathrm{b}}\end{array}$ & Breach Name & $\begin{array}{c}2012 \text { Fish Passage } \\
\text { Flow (cfs) }\end{array}$ & $\begin{array}{l}2005 \text { Fish Passage } \\
\text { Flow }(\mathrm{cfs})^{\mathrm{c}}\end{array}$ & $\begin{array}{c}\text { Change from } 2005 \\
\text { to } 2012 \text { (cfs) }\end{array}$ \\
\hline \multirow[t]{8}{*}{ Escalante Ranch } & ER-IN-1 & $\mathrm{NA}^{\mathrm{d}}$ & 14,600 & NA \\
\hline & ER-IN-2 & NA & 20,500 & NA \\
\hline & ER-IN-3 & 21,500 & 15,100 & $+6,400$ \\
\hline & ER-IN-4 & 23,900 & 16,200 & $+7,700$ \\
\hline & ER-IN-5 & 20,100 & 15,200 & $+4,900$ \\
\hline & ER-IN-6 & 22,600 & 14,200 & $+8,400$ \\
\hline & ER-IN-7 & 18,500 & 15,200 & $+3,300$ \\
\hline & ER-OUT & 14,300 & 15,600 & $-1,300$ \\
\hline \multirow[t]{4}{*}{ Bonanza Bridge } & BB-IN-1 & 23,700 & 22,300 & $+1,400$ \\
\hline & BB-IN-2 & 24,700 & 17,300 & $+7,400$ \\
\hline & BB-IN-3 & 27,900 & 16,300 & $+11,600$ \\
\hline & BB-OUT & 20,800 & 17,300 & $+3,500$ \\
\hline Stirrup & ST-OUT & 20,200 & 16,300 & $+3,900$ \\
\hline \multirow[t]{4}{*}{ Above Brennan } & AB-IN-1 & 19,700 & 16,300 & $+3,400$ \\
\hline & AB-IN-2 & 23,000 & 16,300 & $+6,700$ \\
\hline & AB-IN-3 & 21,900 & 16,300 & $+5,600$ \\
\hline & AB-OUT & 13,000 & 16,300 & $-3,300$ \\
\hline \multirow[t]{2}{*}{ Johnson Bottom } & JB-OUT-1 & 18,700 & 15,400 & $+3,300$ \\
\hline & JB-OUT-2 & 19,000 & 15,400 & $+3,600$ \\
\hline \multirow[t]{2}{*}{ Leota Bottom } & LB7-IN & 20,300 & NA & NA \\
\hline & LB7A-IN & 15,800 & NA & NA \\
\hline \multirow[t]{2}{*}{ Old Charlie Wash } & OC-OUT-1 & 16,700 & 15,400 & $+1,300$ \\
\hline & OC-OUT-2. & 11,600 & 15,400 & $-3,800$ \\
\hline Mean & & 19,900 & 16,200 & $+3,895$ \\
\hline
\end{tabular}

a Based on minimum fish passage depth of $1 \mathrm{ft}$ reported in Burdick (1997).

b Sheppard Bottom was not included in this comparison because fish passage flow was not determined.

c Fish passage flows for 2005 were estimated by the authors using the elevations associated with reported 2005 connection flows in Tetra Tech (2005) and Bestgen et al. (2011), adding $1 \mathrm{ft}$ to the elevation, and determining the associated flow in the stage-flow table provided by USGS for 2005. Since the Ouray gage was not in place in 2005, we used the 2012 stage flow table for the Ouray gage to estimate fish passage flows for Johnson Bottom, Leota Bottom, and Old Charlie Wash.

d $\quad \mathrm{NA}=$ not available. 
In the descriptions below, the following critical elevations and associated estimated flows are identified for each levee breach and its connection channel:

- River water surface elevation (flow): water surface elevation and associated flow as surveyed at river's edge nearest each levee breach.

- Breach elevation (flow): minimum elevation and associated flow measured along levee breach cross section, representing the elevation and flow at which river flow would begin to enter the levee breach.

- Connection elevation (flow): minimum elevation and associated flow in the connection channel that would allow water to flow between the river and floodplain wetland as determined from a series of cross sections measured between the levee breach and the entrance to the floodplain wetland.

- Fish passage elevation (flow): minimum water surface elevation and associated flow that would provide at least $1 \mathrm{ft}(30 \mathrm{~cm})$ of depth along the entire connection channel. This is considered to be the minimum depth that would allow subadult and adult razorback suckers to swim between the wetland and river (Burdick 1997).

\subsection{ESCALANTE RANCH}

The Escalante Ranch wetland, formerly known as Thunder Ranch, was surveyed on October 23, 2012. Table 3 summarizes the dates and times of the floodplain surveys, with corresponding lag-adjusted local flow conditions at the time of the survey. The local flow at Escalante Ranch at the time of the survey was estimated to be 1,190 cfs (Table 3).

Eight locations were surveyed at Escalante Ranch: seven upstream inlets and one downstream outlet (Figure 3). The approximate distance between the upstream-most inlet (ER-IN-1) and the outlet (ER-OUT) was 1.3 river miles ( 2 river km). Characterization of levee breaches and connection channel elevations at each of these locations is provided below. As summarized in Table 5, the 2012 minimum connection flow at Escalante Ranch was estimated to be 11,300 cfs (ER-OUT), which was about a $134 \mathrm{cfs}$ increase from estimates at the lowest connecting breach in 2005 (ER-IN-6; Table 5). Estimated connection flows among upstream breaches increased by about $4,134 \mathrm{cfs}$, whereas connection flows for the downstream breach, ER-OUT, decreased by about $1,133 \mathrm{cfs}$ in 2012. Estimated minimum fish passage flows for Escalante Ranch showed the same pattern as connection flows, but were on average 3,317 cfs higher than connection flows (Table 5).

ER-IN-1. ER-IN-1 had been intentionally filled with rip-rap prior to our survey and was no longer a functioning levee breach. Nine locations were surveyed at ER-IN-1 (Figure 4). River water surface elevation was not recorded for this site; therefore, the estimated mean water surface elevation for the nearest site (ER-IN-3) was used: 4,730.55 ft. Based on our survey, the 


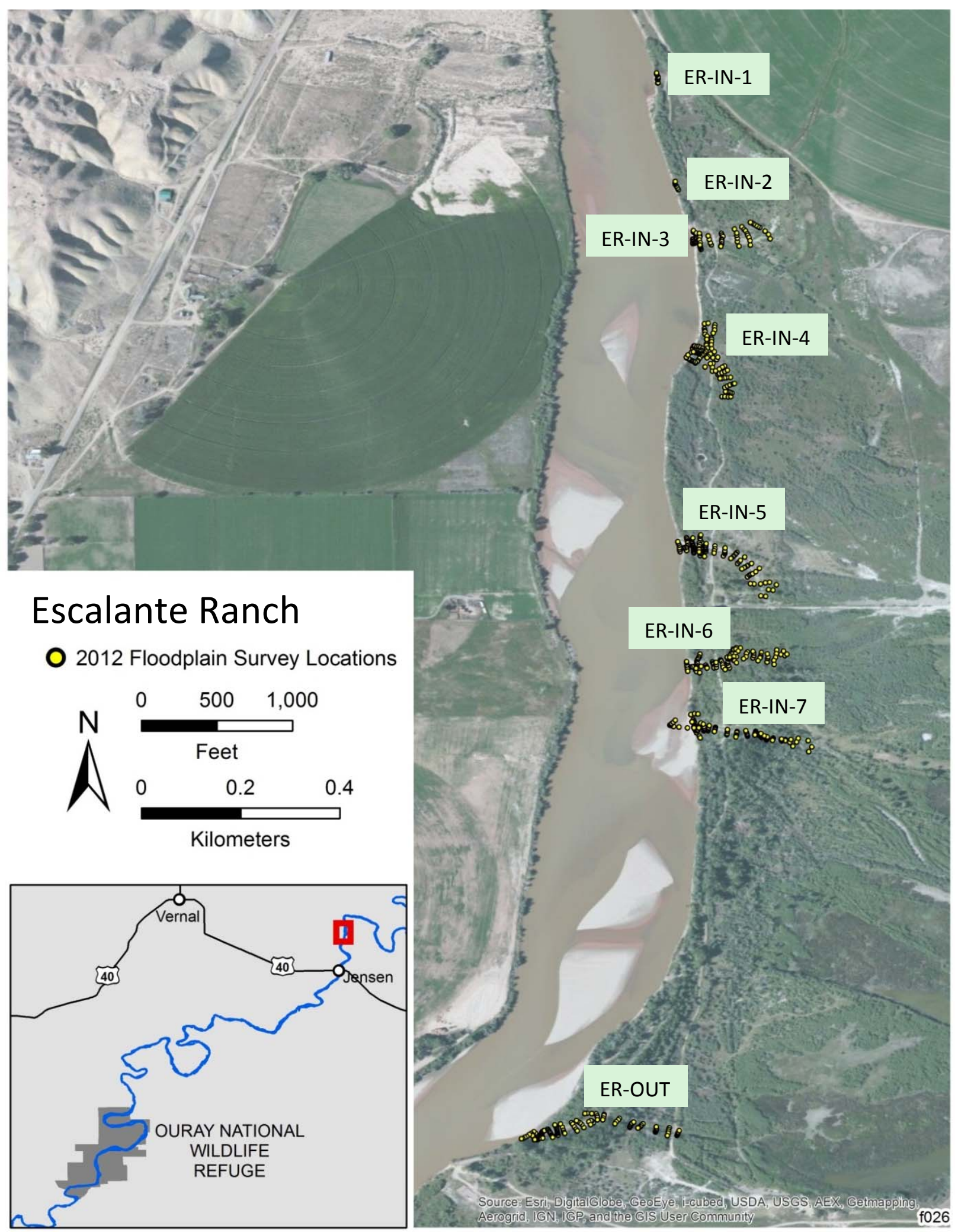

FIGURE 3 Escalante Ranch Survey Locations. The date of the aerial imagery differs from the date of the survey; aerial imagery does not depict exact conditions at the time of the survey. 


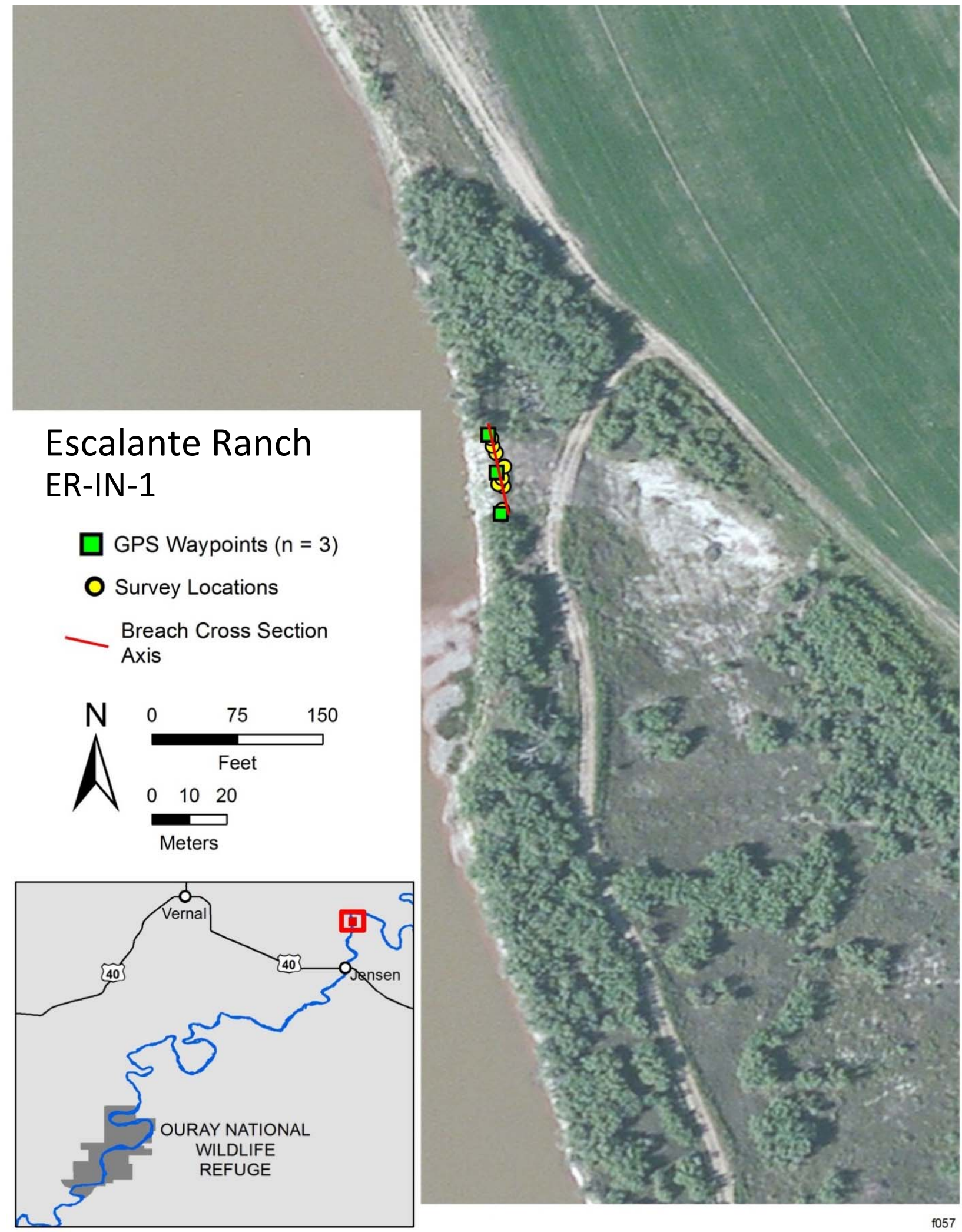

FIGURE 4 ER-IN-1 Survey Locations. The date of the aerial imagery differs from the date of the survey; aerial imagery does not depict exact conditions at the time of the survey. 
estimated breach flow at ER-IN-1 in 2012 was about 22,000 cfs (Table 4). No floodplain and channel elevation surveys were conducted at ER-IN-1, but any channel between the filled breach and the wetland is expected to be at a lower elevation than the filled breach elevation. Therefore, the breach flow for ER-IN-1 is expected to be equivalent to the connection flow. The estimated 2012 breach flow for ER-IN-1 was approximately 10,500 cfs higher than flow reported by Tetra Tech (2005).

ER-IN-2. ER-IN-2 also had been intentionally filled with rip-rap prior to our survey and was no longer a functioning levee breach. Six locations were surveyed at ER-IN-2 (Figure 5). River water surface elevation was not recorded for this site; therefore, the estimated mean water elevation for the nearest site (ER-IN-3) was used: 4,730.55 ft. Based on our survey, the estimated breach flow at ER-IN-2 in 2012 was about 23,000 cfs (Table 4). No floodplain and channel elevation surveys were conducted at ER-IN-2, but any channel between the filled breach and the wetland is expected to be a lower elevation than the filled breach elevation. Therefore, the breach flow for ER-IN-2 is expected to equal the connection flow. The estimated 2012 breach flow for ER-IN-2 was approximately 6,200 cfs higher than the flow reported by Tetra Tech (2005).

ER-IN-3. Seventy-four locations were surveyed at ER-IN-3 (Figure 6). The estimated mean river water surface elevation near ER-IN-3 was 4,730.55 ft. At the time of the survey, ER-IN-3 was a well-defined sandy breach with willows and annual plants growing in the breach area. Based on our survey, the estimated breach flow at ER-IN-3 in 2012 was 14,500 cfs (Table 4). The connection flow was estimated to be $18,100 \mathrm{cfs}$, and the highest portion of the channel that limited connection was located approximately two-thirds of the way up the channel from the breach (Figure B-1). This estimated connection flow was approximately 6,200 cfs higher than the connection flow reported by Tetra Tech (2005). Tetra Tech (2005) noted significant bank erosion and deposition within the breach at this site in 2005 (Table 4). The estimated fish passage flow for ER-IN-3 in 2012 was estimated at 21,500 cfs, which is 6,400 cfs higher than in 2005 (Table 6).

ER-IN-4. A total of 101 locations were surveyed at ER-IN-4 (Figure 7). The estimated mean river water surface elevation near ER-IN-4 was 4,730.45 ft. At the time of the survey, ERIN-4 was completely blocked by sand with no apparent cut in the levee. Based on our survey, the estimated breach flow at ER-IN-4 in 2012 was 17,600 cfs (Table 4). The connection flow for ER-IN-4 in 2012 was estimated to be $20,300 \mathrm{cfs}$, and the highest portion of the channel that limited connection was located near the wetland edge (Figure B-2). The estimated connection flow for ER-IN-4 was approximately 7,367 cfs higher than the connection flow reported by Tetra Tech (2005). Tetra Tech (2005) noted a general trend of sand deposition at this site (Table 4). The estimated fish passage flow for ER-IN-4 in 2012 was estimated at 23,900 cfs, which is 7,700 cfs higher than in 2005 (Table 6).

ER-IN-5. A total of 112 locations were surveyed at ER-IN-5 (Figure 8). The estimated mean river water surface elevation at ER-IN-5 was 4,730.04 ft. At the time of the survey, ER-IN-5 was a shallow breach (approximately $3 \mathrm{ft}$ in depth) with loose sand. Based on our survey, the breach flow at ER-IN-5 in 2012 was estimated to be 15,200 cfs (Table 4). The connection flow was estimated to be $16,800 \mathrm{cfs}$, and the highest portion of the channel that 


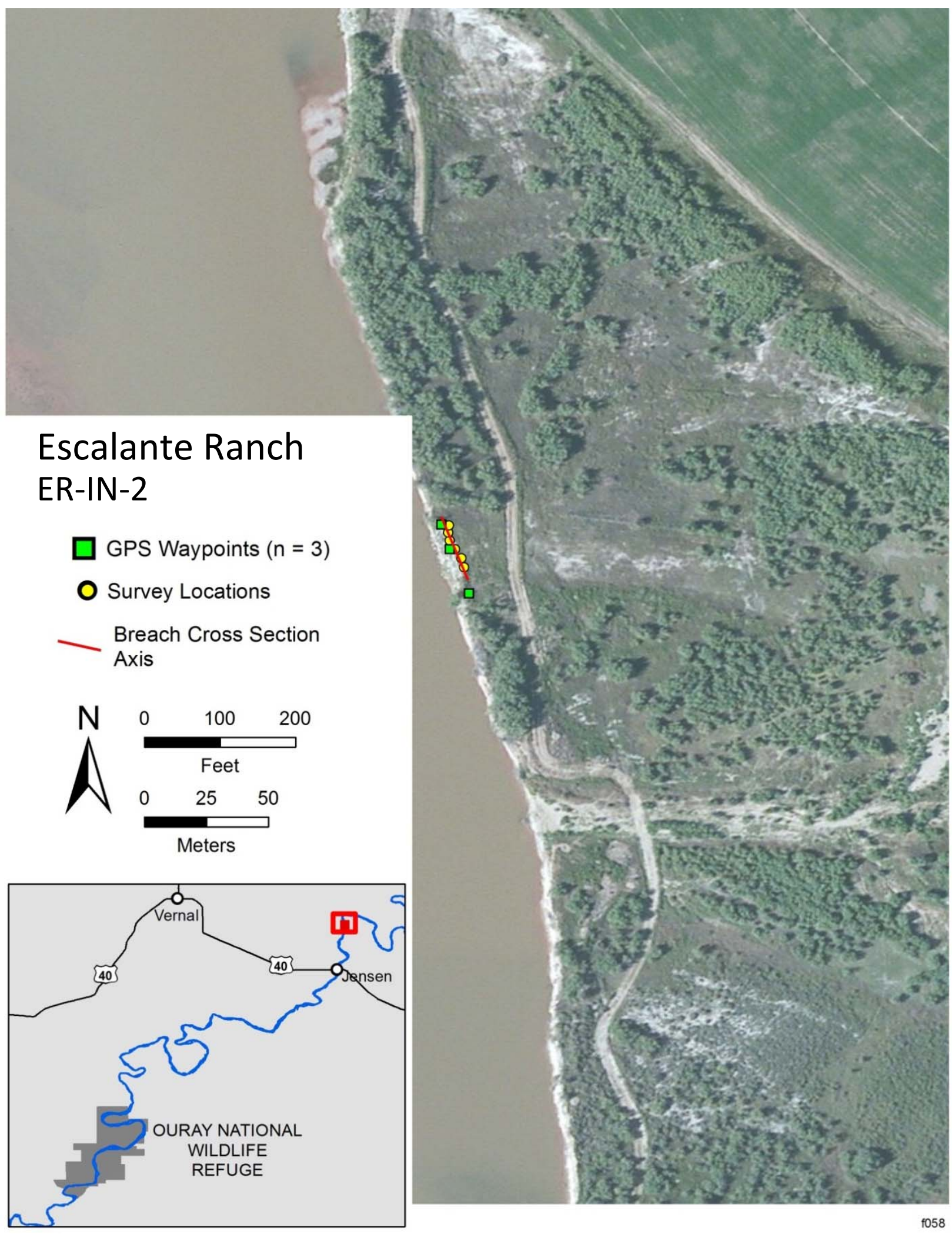

FIGURE 5 ER-IN-2 Survey Locations. The date of the aerial imagery differs from the date of the survey; aerial imagery does not depict exact conditions at the time of the survey. 

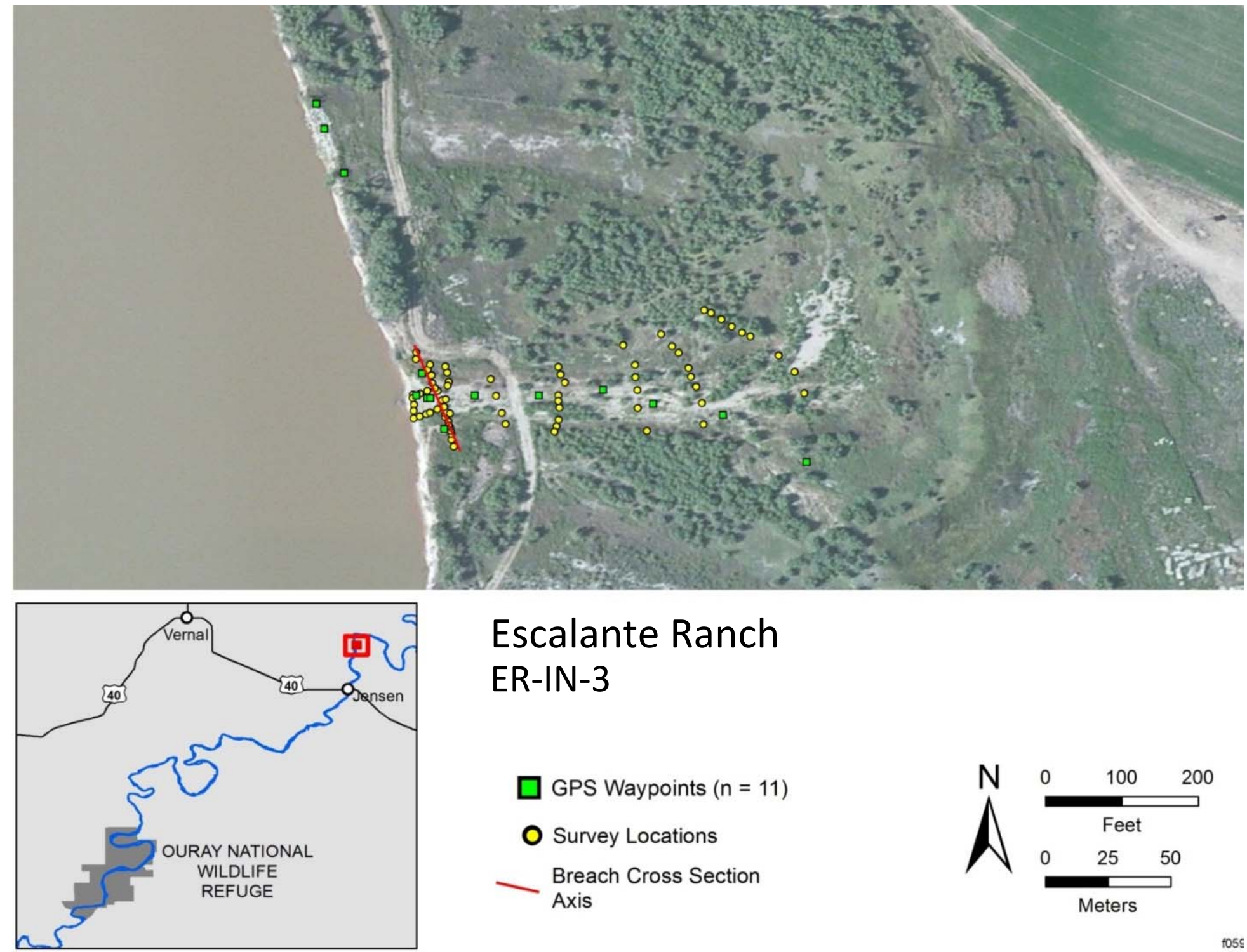

\section{Escalante Ranch ER-IN-3}

$$
\begin{aligned}
& \square \text { GPS Waypoints }(n=11) \\
& \text { Survey Locations } \\
& \text { Breach Cross Section } \\
& \text { Axis }
\end{aligned}
$$

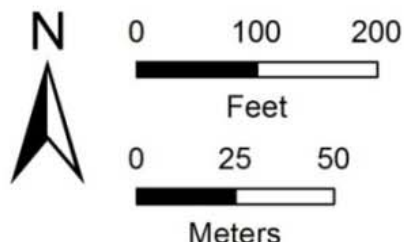

FIGURE 6 ER-IN-3 Survey Locations. The date of the aerial imagery differs from the date of the survey; aerial imagery does not depict exact conditions at the time of the survey. 


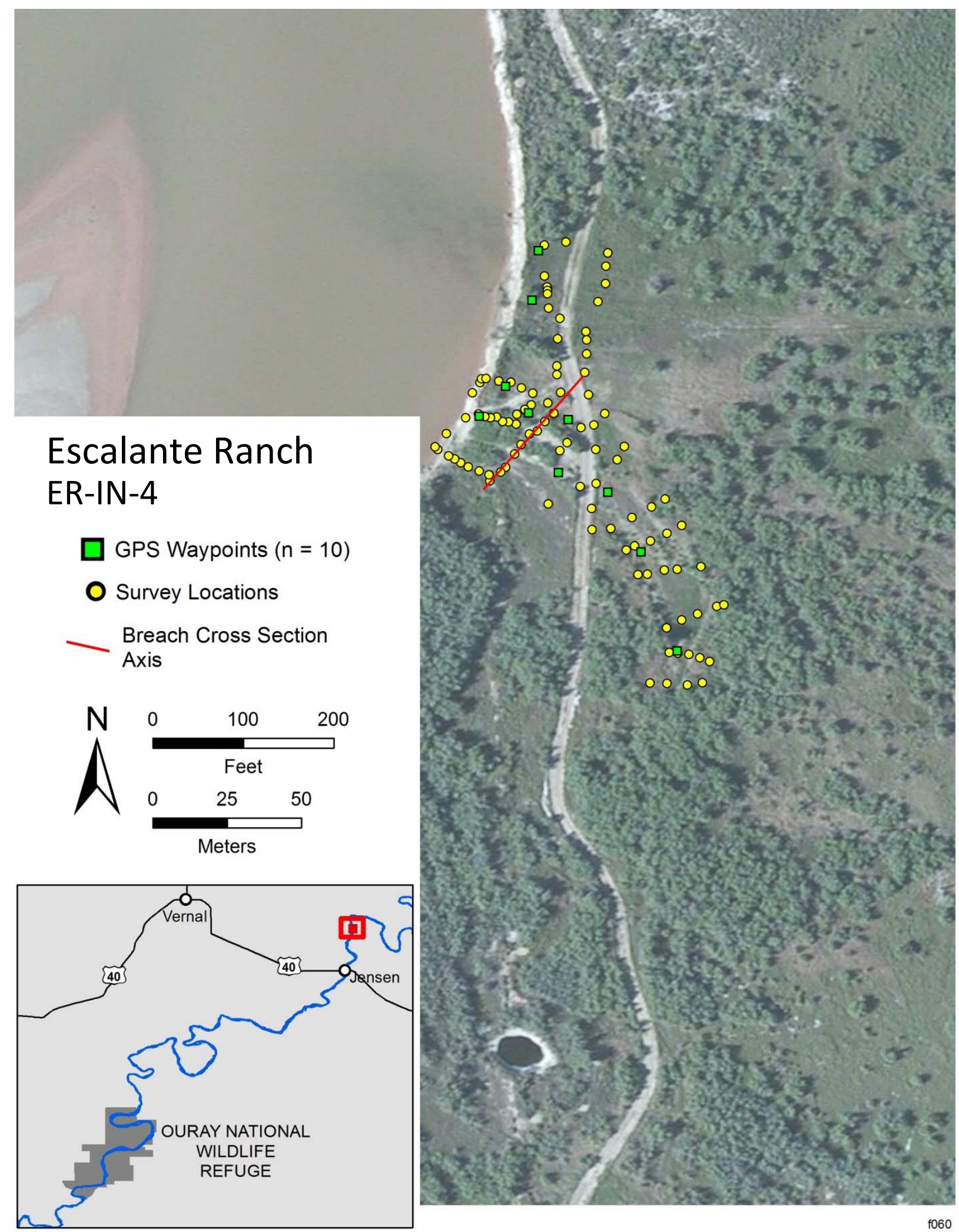

FIGURE 7 ER-IN-4 Survey Locations. The date of the aerial imagery differs from the date of the survey; aerial imagery does not depict exact conditions at the time of the survey. 

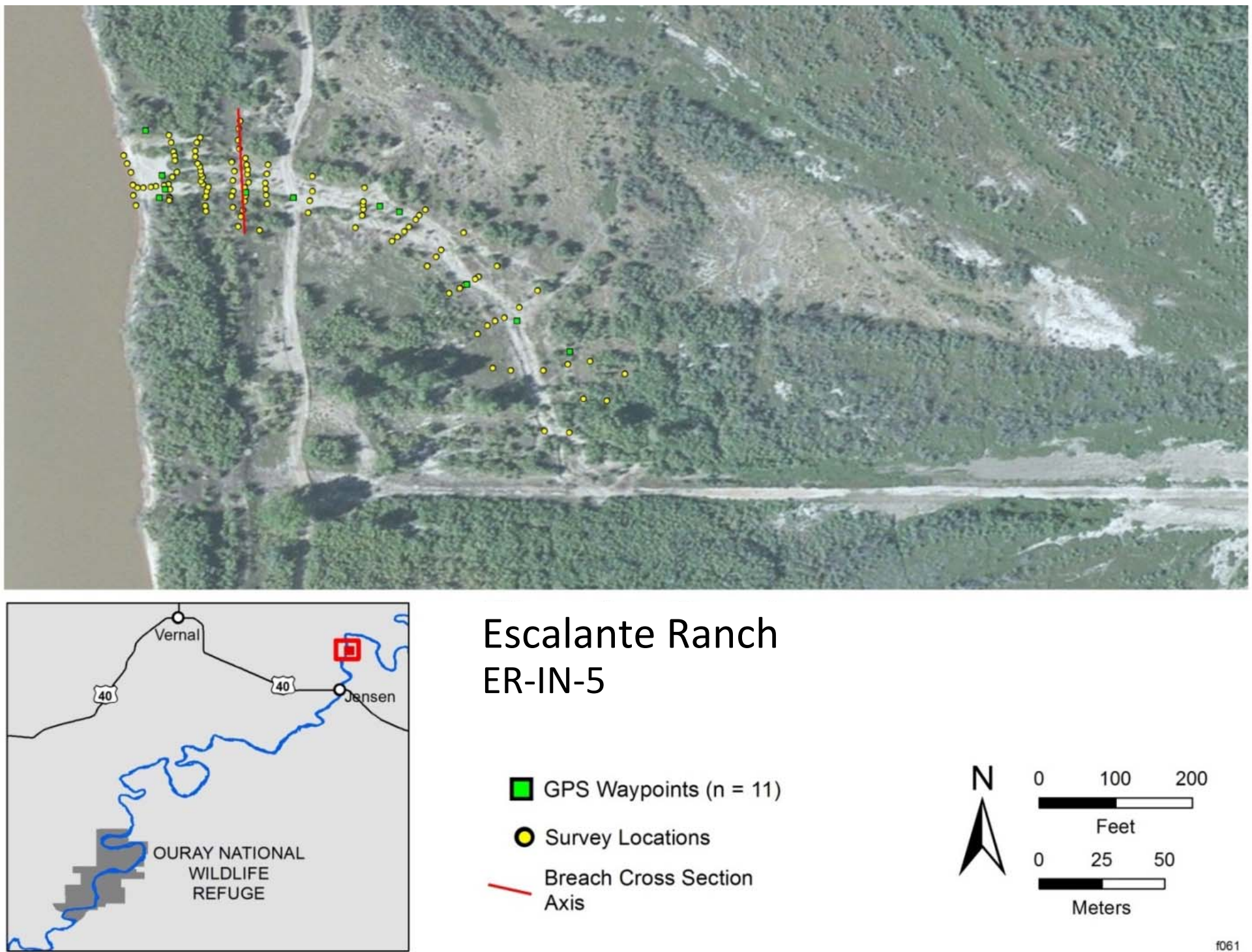

\section{Escalante Ranch} ER-IN-5

$\square$ GPS Waypoints $(n=11)$

O Survey Locations

Breach Cross Section Axis

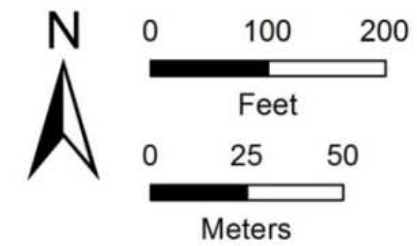

5061

FIGURE 8 ER-IN-5 Survey Locations. The date of the aerial imagery differs from the date of the survey; aerial imagery does not depict exact conditions at the time of the survey. 
limited connection was near the wetland edge (Figure B-3). This estimated connection flow was approximately 4,800 cfs higher than the connection flow reported by Tetra Tech (2005). Tetra Tech (2005) noted minor bank erosion and sand deposition at this site (Table 4). The estimated fish passage flow for ER-IN-5 in 2012 was estimated at 20,100 cfs, which is 4,900 cfs higher than in 2005 (Table 6).

ER-IN-6. A total of 104 locations were surveyed at ER-IN-6 (Figure 9). The estimated mean river water surface elevation at ER-IN-6 was 4,729.67 ft. At the time of the survey, ER-IN-6 was a shallow breach (approximately $3 \mathrm{ft}$ in depth) with loose sand. Based on our survey, the breach flow at ER-IN-6 in 2012 was estimated to be 15,100 cfs (Table 4). The connection flow was estimated to be 19,200 cfs, and the highest portion of the channel that limited connection was located approximately one-third of the way up the channel from the breach (Figure B-4). This estimated connection flow was approximately 8,034 cfs higher than the connection flow reported by Tetra Tech (2005). Tetra Tech (2005) noted a general trend of sand deposition at this site (Table 4). The estimated fish passage flow for ER-IN-6 in 2012 was $22,600 \mathrm{cfs}$, which is $8,400 \mathrm{cfs}$ higher than in 2005 (Table 6).

ER-IN-7. A total of 109 locations were surveyed at ER-IN-7 (Figure 10). The estimated mean river water surface elevation at ER-IN-7 was 4,729.80 ft. At the time of the survey, ER IN 7 was a broad, low, sandy breach. Based on our survey, the breach flow at ER IN-7 in 2012 was estimated to be 13,800 cfs (Table 4). The connection flow was estimated to be 15,300 cfs, and the highest portion of the channel that limited connection was located approximately two-thirds of the way up the channel from the breach (Figure B-5). This estimated connection flow was approximately 3,300 cfs higher than the connection flow reported by Tetra Tech (2005). Tetra Tech (2005) noted a general trend of sand deposition at this site (Table 4). The estimated fish passage flow for ER-IN-7 in 2012 was 18,500 cfs, which is 3,300 cfs higher than in 2005 (Table 6).

ER-OUT. A total of 123 locations were surveyed at ER-OUT (Figure 11). The estimated mean river water surface elevation at ER-OUT was 4,728.90 $\mathrm{ft}$. At the time of the survey, ER OUT was a long broad channel extending from the river to the wetland. Several areas of scour were noted in the channel both near the levee breach and where the channel changes direction from east-west to northeast-southwest (Figure 11). This scour presumably occurred during periods when high flows passed through the wetland from upstream breaches through the outlet during peak flow, and as the wetland drained during flood recession. Based on our survey, the breach flow at ER-OUT in 2012 was estimated to be 10,800 cfs. The connection flow was estimated to be $11,300 \mathrm{cfs}$, and the highest portion of the channel that limited connection was located approximately two-thirds of the way up the channel from the breach (Figure B-6). This estimated connection flow was approximately 1,133 cfs lower than the connection flow reported by Tetra Tech (2005). Tetra Tech (2005) noted some scouring upstream of the upper control structure that exists at this site (Table 4). The estimated fish passage flow for ER-OUT in 2012 was $14,300 \mathrm{cfs}$, which is $1,300 \mathrm{cfs}$ lower than in 2005 (Table 6). 

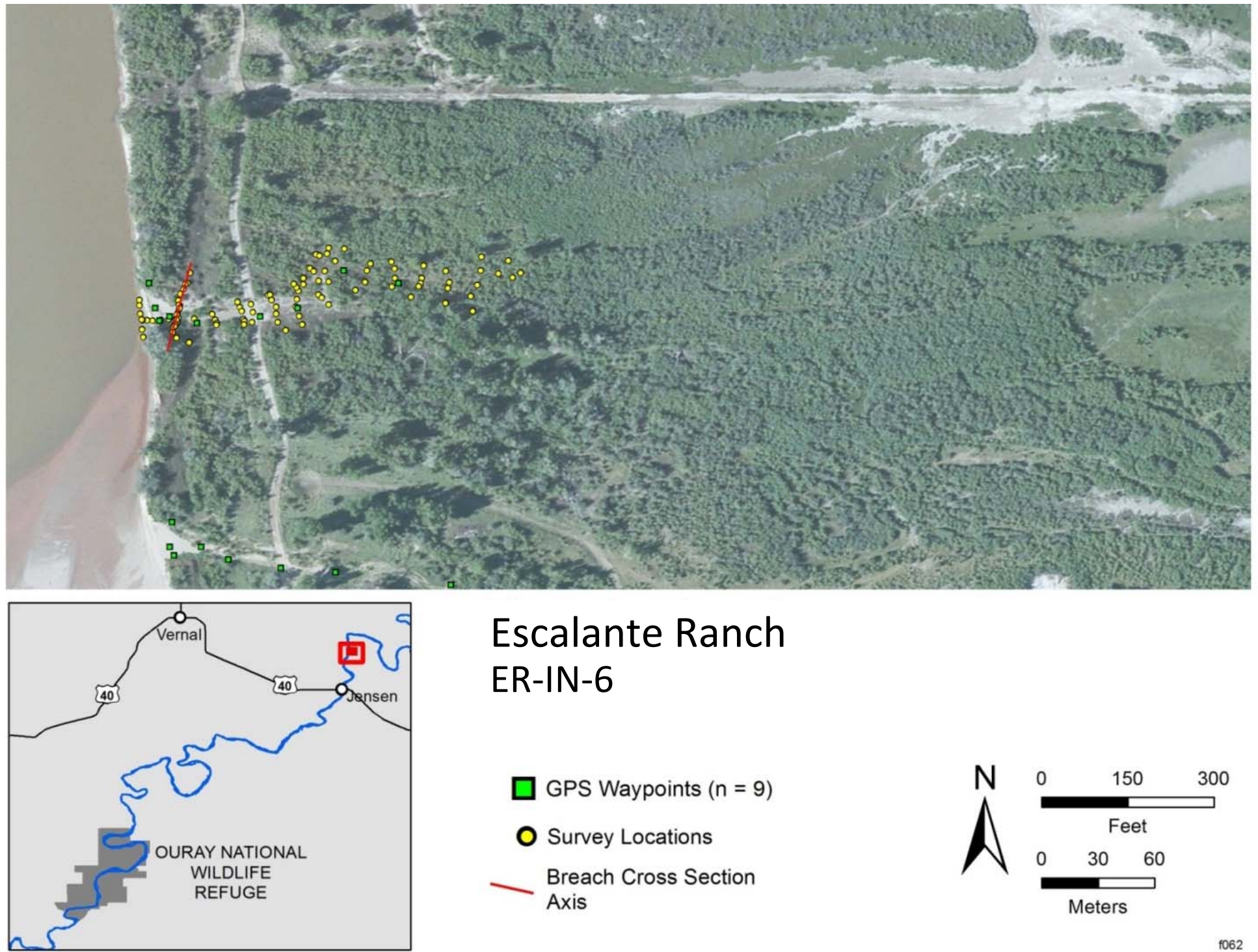

\section{Escalante Ranch ER-IN-6}

$\square$ GPS Waypoints ( $n=9)$

O Survey Locations

Breach Cross Section Axis

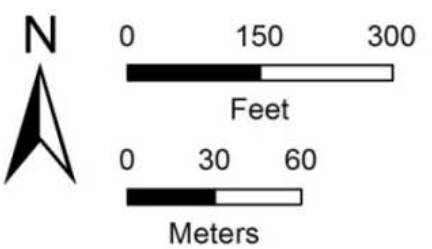

062

FIGURE 9 ER-IN-6 Survey Locations. The date of the aerial imagery differs from the date of the survey; aerial imagery does not depict exact conditions at the time of the survey. 

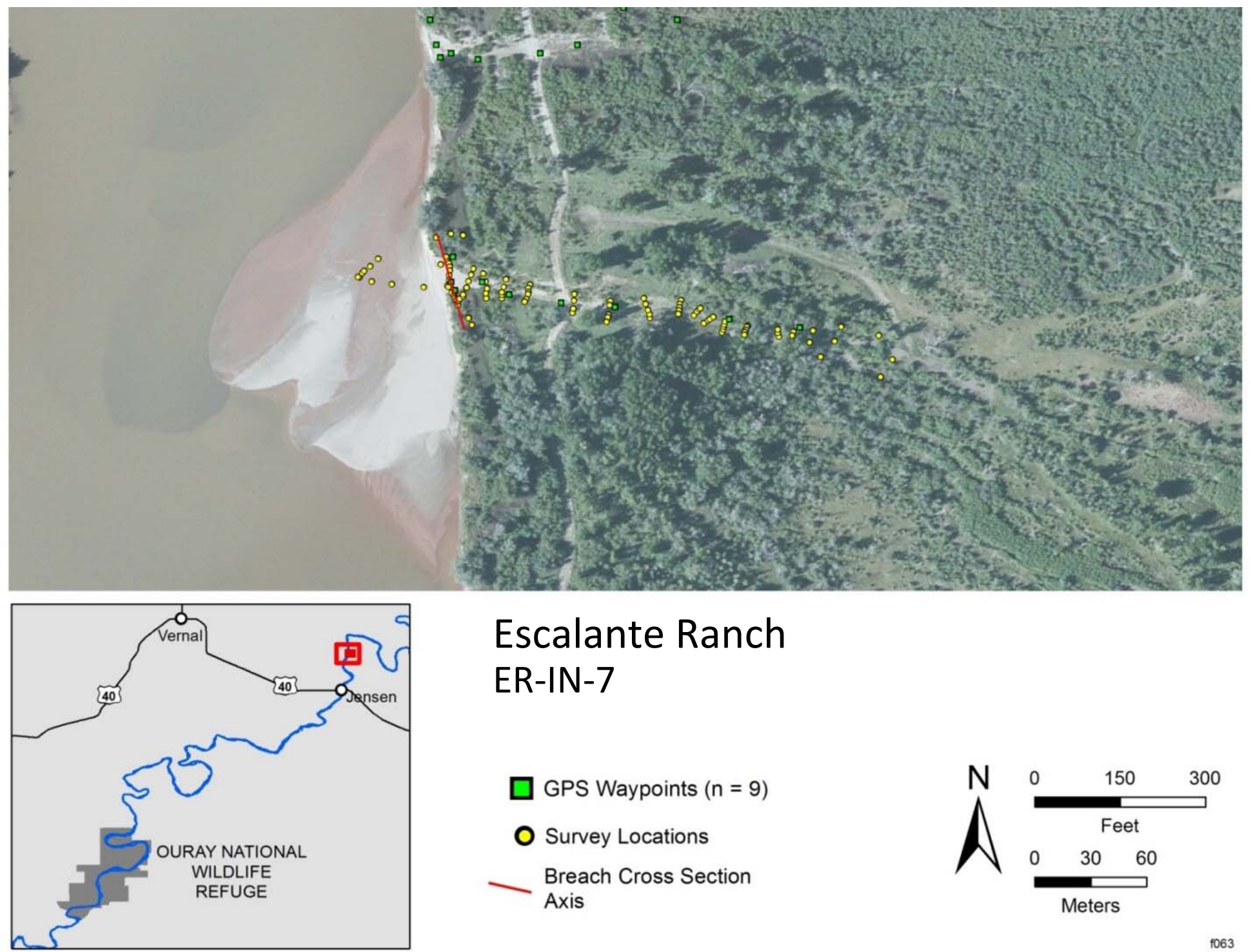

\section{Escalante Ranch}

\section{ER-IN-7}

$\square$ GPS Waypoints $(n=9)$

O Survey Locations

Breach Cross Section

Axis

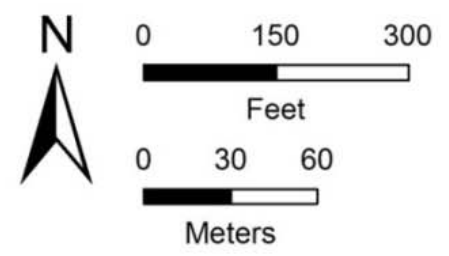

f063

FIGURE 10 ER-IN-7 Survey Locations. The date of the aerial imagery differs from the date of the survey; aerial imagery does not depict exact conditions at the time of the survey. 

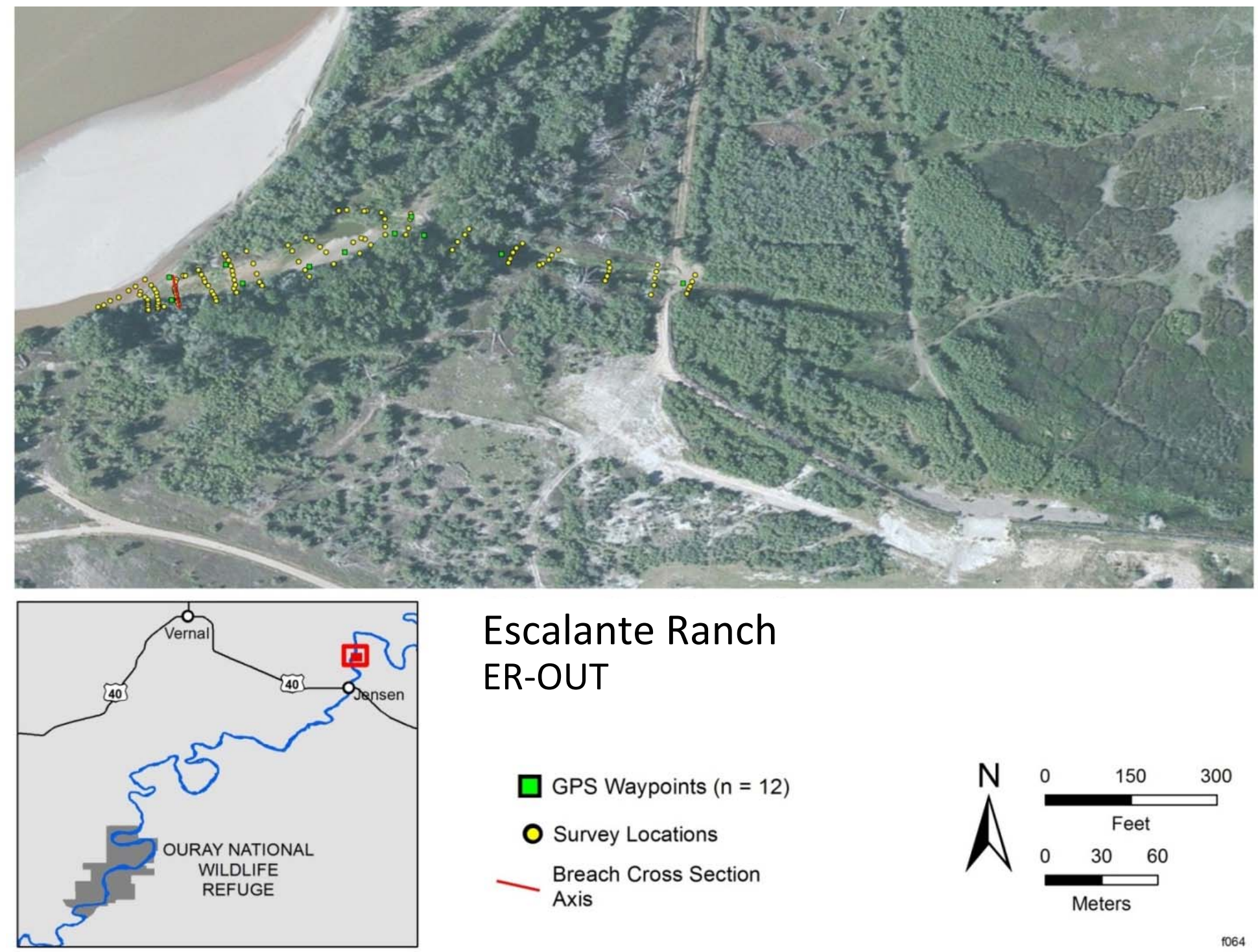

\section{Escalante Ranch ER-OUT}

$\square$ GPS Waypoints ( $n=12$ )

O Survey Locations

Breach Cross Section Axis

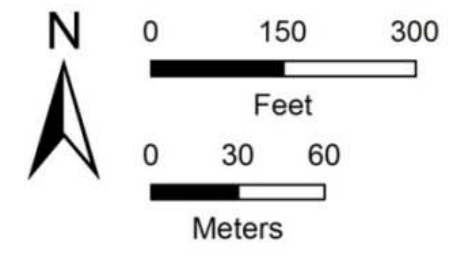

1064

FIGURE 11 ER-OUT Survey Locations. The date of the aerial imagery differs from the date of the survey; aerial imagery does not depict exact conditions at the time of the survey. 


\subsection{BONANZA BRIDGE}

The Bonanza Bridge wetland was surveyed on October 25, 2012. Table 3 summarizes the dates and times of the floodplain surveys, with corresponding lag-adjusted local flow conditions at the time of the survey. The local flow at Bonanza Bridge at the time of the survey was calculated to be $1,235 \mathrm{cfs}$ (Table 3 ).

Four breach locations were surveyed at Bonanza Bridge: three upstream inlets and a downstream outlet (Figure 12). The approximate distance between the upstream-most inlet (BB-IN-1) and the outlet (BB-OUT) was 0.7 river miles (1.1 river $\mathrm{km}$ ). Characterization of levee and floodplain elevations at each of these locations is provided below. The 2012 minimum connection flow at Bonanza Bridge was estimated to be 17,400 cfs (BB-OUT), which was about a 4,400 cfs increase from estimates at the lowest connecting breach in 2005 (BB-IN-3; Table 5). Estimated connection flows among upstream breaches increased by about 7,100 cfs, and the estimated connection flow at the outlet increased by about 3,500 cfs. Fish passage flow estimates for Bonanza Bridge showed the same pattern as connection flow, but were on average 3,475 cfs higher than connection flows (Table 6).

BB-IN-1. Fifty-six locations were surveyed at BB-IN-1 (Figure 13). The estimated mean river water surface elevation at BB-IN-1 was 4,703.1 ft. At the time of the survey, the levee breach at BB-IN-1 was partially blocked with loose sand, but led to a relatively narrow, mostly grassy channel. Based on our survey, the breach and connection flows at BB-IN-1 were estimated to be 17,400 cfs and 20,100 cfs, respectively (Table 4), and the highest portion of the channel that limited connection was located approximately one-third of the way up the channel from the breach (Figure B-7). This connection flow was approximately 1,600 cfs higher than the connection flows reported by Tetra Tech (2005). The increase in connection flow resulted from the accumulation of sand deposits and debris in the levee and along the connection channel, including a very large deposit of sand at the wetland end of the channel that appeared to originate from inflow through BB-IN-2 (see description under BB-IN-2) (Figure 13). In addition, portions of the channel were partially blocked with cut brush, although flow could pass through this material. Two sand roads crossed portions of the channel including near the breach and midway between the breach and the wetland (Figure 13). These roads did not appear to affect the magnitude of connection flow at the time of the survey. Tetra Tech (2005) suggested that the breach elevation was too high for proper connection at reported flows of 13,000 cfs and actual connection occurred at flows between 18,500 and 19,700 cfs (Table 4). The estimated fish passage flow for BB-IN-1 in 2012 was 23,700 cfs, which is 1,400 cfs higher than in 2005 (Table 6).

BB-IN-2. Sixty locations were surveyed at BB-IN-2 (Figure 14). The estimated mean river water surface elevation at BB-IN-2 was 4,702.9 ft. At the time of survey, BB-IN-2 was partially blocked with a deposit of loose sand. Based on our survey, the breach and connection flows at BB-IN-2 were estimated to be 16,300 cfs and 21,100 cfs, respectively (Table 4), and the highest portion of the channel that limited connection was located approximately half way up the channel from the breach (Figure B-8). This connection flow was approximately 7,200 cfs higher than the connection flow reported by Tetra Tech (2005). The increase in connection flow resulted from the accumulation of sand deposits and debris in the levee breach, including a very 


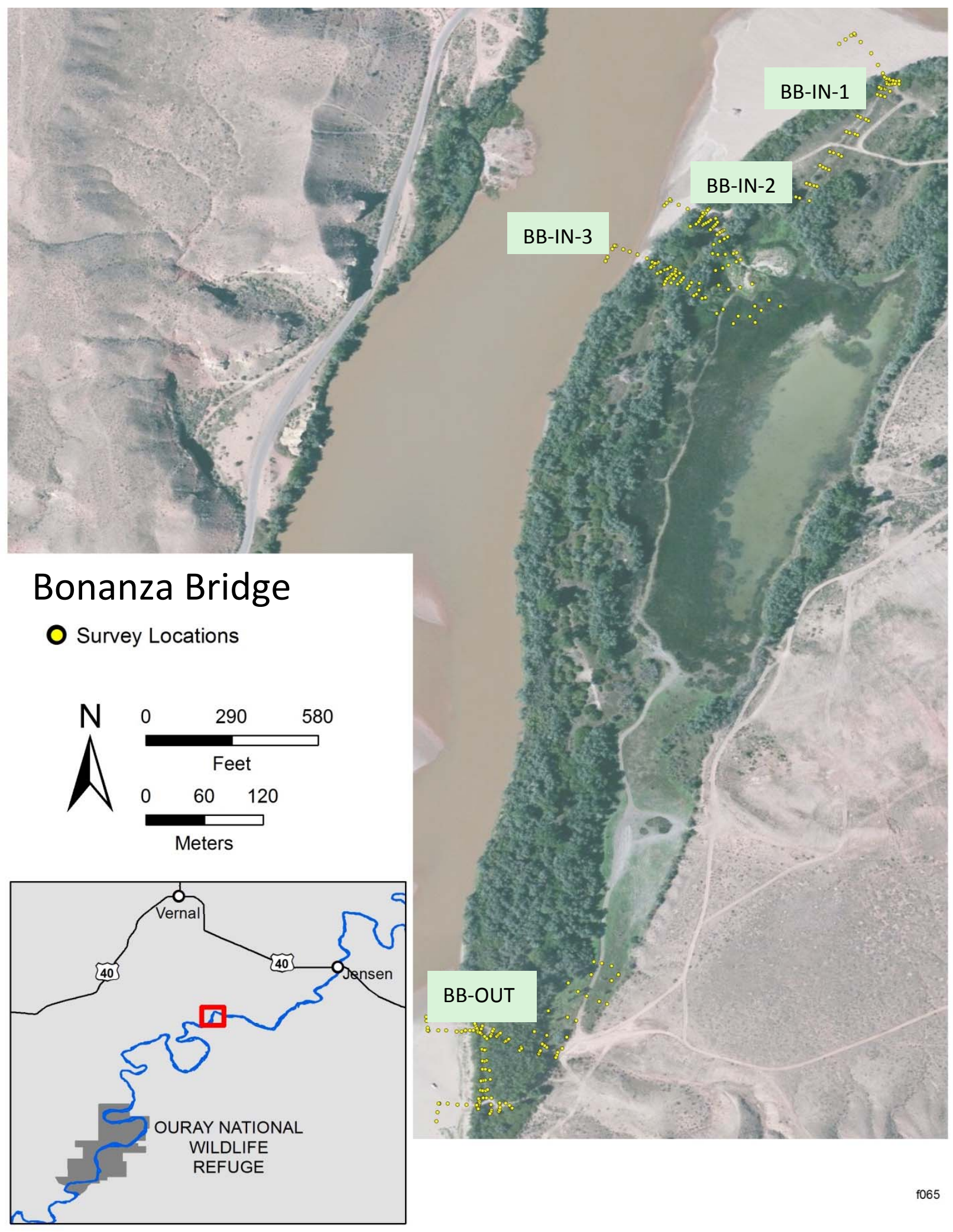

FIGURE 12 Bonanza Bridge Survey Locations. The date of the aerial imagery differs from the date of the survey; aerial imagery does not depict exact conditions at the time of the survey. 


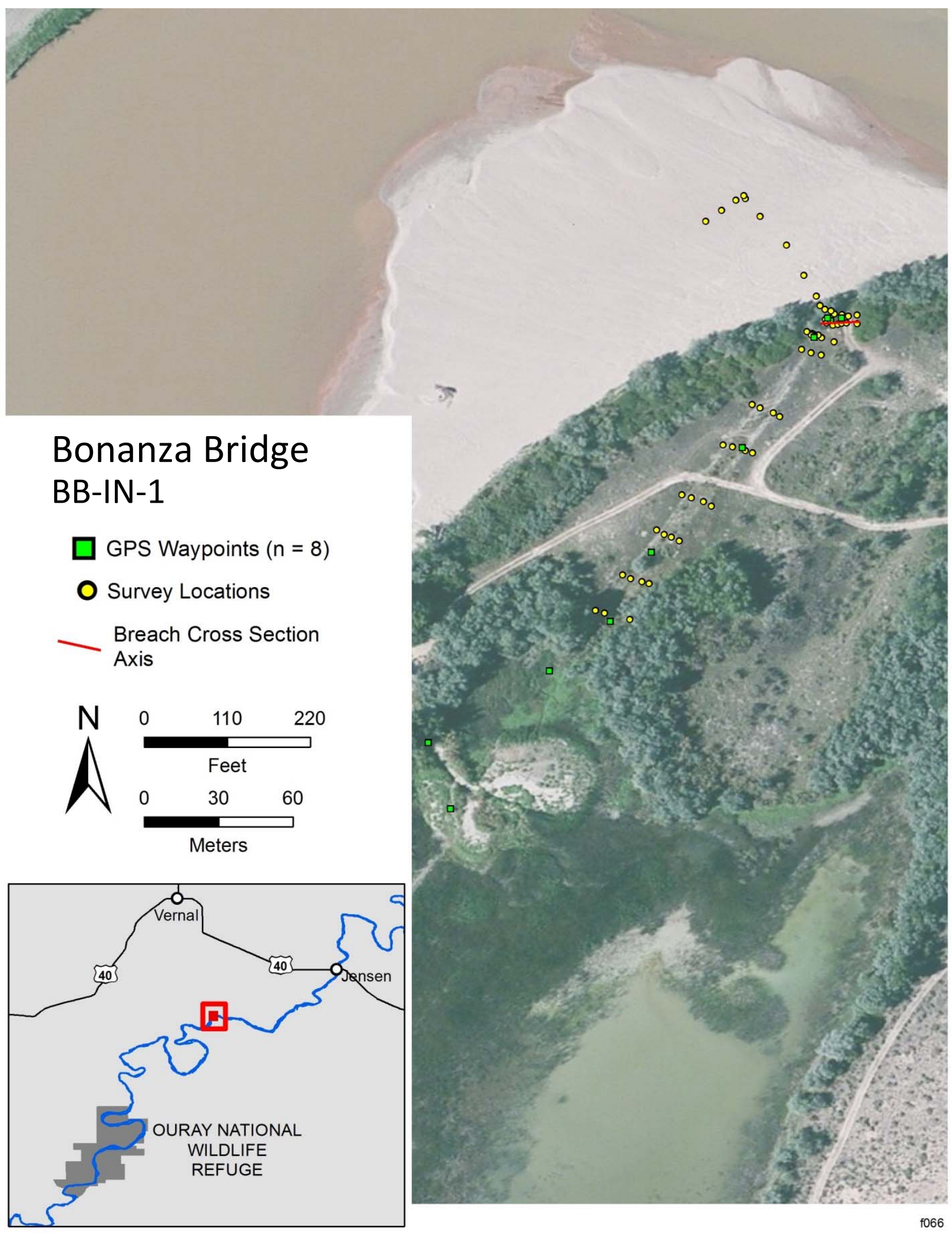

FIGURE 13 BB-IN-1 Survey Locations. The date of the aerial imagery differs from the date of the survey; aerial imagery does not depict exact conditions at the time of the survey. 


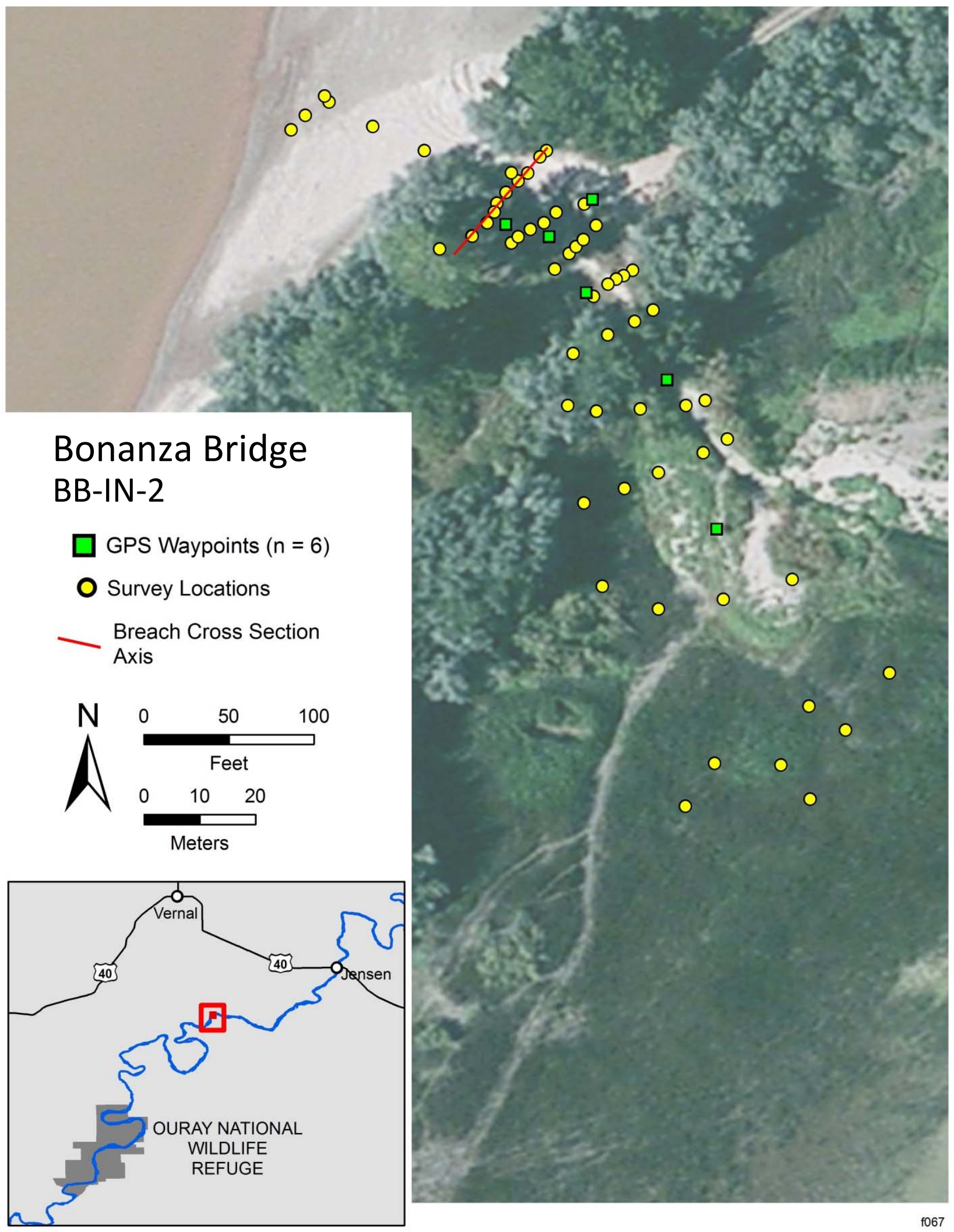

FIGURE 14 BB-IN-2 Survey Locations. The date of the aerial imagery differs from the date of the survey; aerial imagery does not depict exact conditions at the time of the survey. 
large deposit of sand at the wetland end of the channel that, based on a review of aerial imagery, was deposited during the high peak flows of 2008 and 2011 (Figure 14). This deposit was estimated to be approximately $6 \mathrm{ft}(2 \mathrm{~m})$ higher than the wetland surface at the time of the survey. The sand deposit first appears in Google Earth images in 2009 at the end of the connection channel of BB-IN-2, but then increases greatly in size after the 2011 peak flow. A sand road (continuation of the road through BB-IN-1) passed through the levee breach (Figure 14), but did not appear to affect the magnitude of connection flow at the time of the survey. Tetra Tech (2005) suggested that the breach elevation was too high for proper connection at reported flows of 13,000 cfs and that actual connection occurred at flows greater than 13,900 cfs (Table 4). The estimated fish passage flow for BB-IN-2 in 2012 was 24,700 cfs, which is 7,400 cfs higher than in 2005 (Table 6).

BB-IN-3. Forty-nine locations were surveyed at BB-IN-3 (Figure 15). The estimated mean river water surface elevation at BB-IN-3 was 4,702.8 ft. At the time of survey, BB-IN-3 contained large sand deposits and stands of Russian thistle (Salsola sp.). Based on our survey, the breach and connection flows at BB-IN-3 were both estimated to be 24,100 cfs (Table 4), and the highest portion of the channel that limited connection was located at the breach (Figure B-9). This connection flow was approximately $11,100 \mathrm{cfs}$ higher than the connection flow reported by Tetra Tech (2005). Tetra Tech (2005) also noted thick stands of vegetation in the breach and channel (Table 4). The estimated fish passage flow for BB-IN-3 in 2012 was 27,900 cfs, which is 11,600 cfs higher than in 2005 (Table 6).

BB-OUT. One hundred sixteen locations were surveyed at the two breaches of BB-OUT (Figure 16). This breach was referred to as BB-5B in the Tetra Tech (2005) report. Two breaches of hard packed sand near the river lead to a network of unimproved dirt and gravel roads that serve as connection channels to the wetland through a broad low woodland. The estimated mean river water surface elevation was 4,702.0 ft at both breach locations. Based on our survey, the estimated breach and connection flows at BB-OUT in 2012 were 13,100 cfs and 17,400 cfs, respectively (Table 4), and the highest portion of the channel that limited connection was located approximately half way up the channel from the breach (Figure B-10). This connection flow was approximately 3,500 cfs higher than the connection flows reported by Tetra Tech (2005). Tetra Tech (2005) suggested that the breach elevation was too high for proper connection at reported flows of 13,000 cfs and that actual connection occurred at flows between 13,900 and 18,500 cfs (Table 4). The estimated fish passage flow for BB-OUT in 2012 was estimated at 20,800 cfs, which is 3,500 cfs higher than in 2005 (Table 6).

\subsection{STIRRUP}

The Stirrup wetland was surveyed on October 22, 2012. Table 3 summarizes the dates and times of the floodplain surveys, with corresponding lag-adjusted local flow conditions at the time of the survey. The local flow at Stirrup at the time of the survey was calculated to be 1,193 cfs (Table 3 ). 


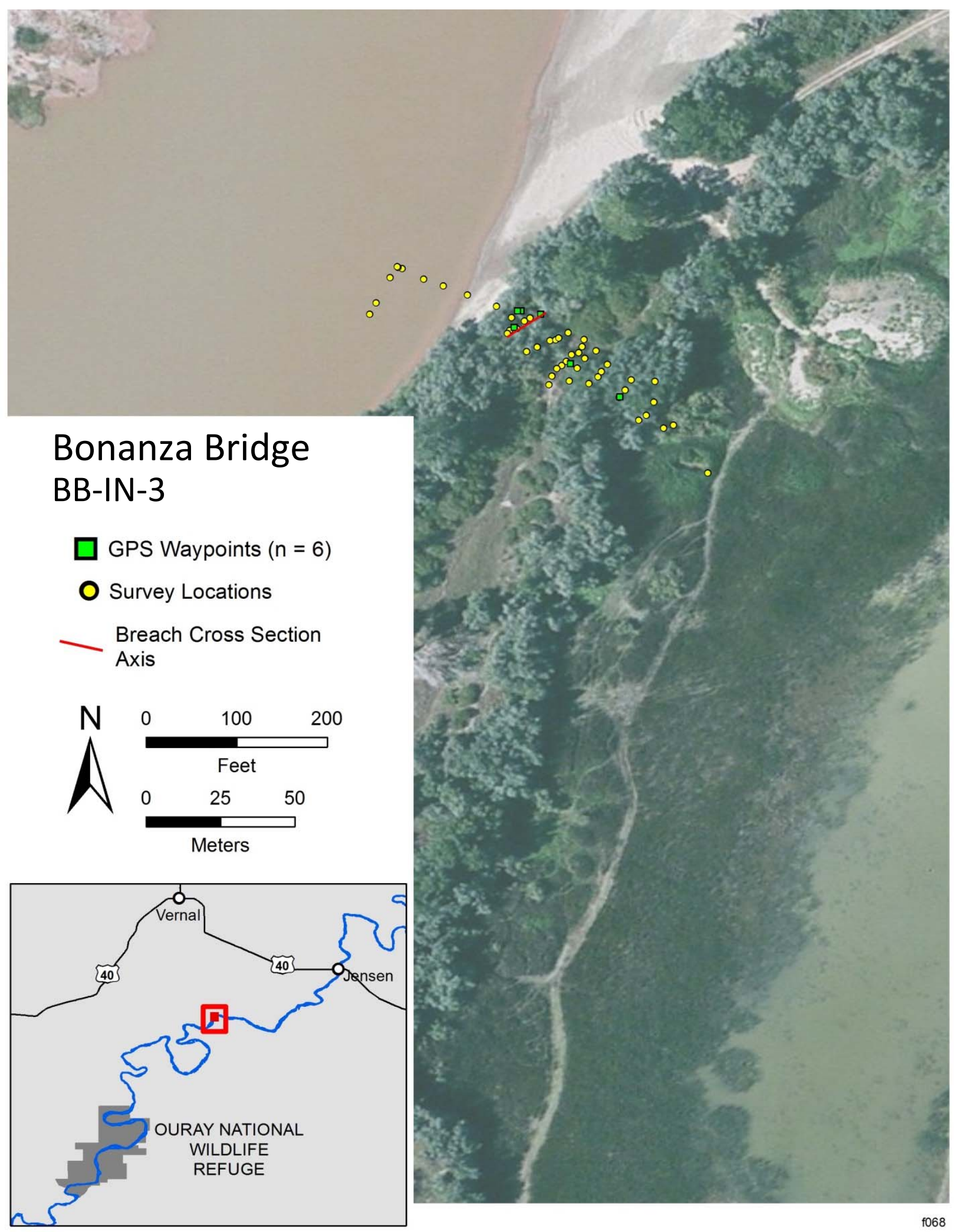

FIGURE 15 BB-IN-3 Breach Survey Locations. The date of the aerial imagery differs from the date of the survey; aerial imagery does not depict exact conditions at the time of the survey. 

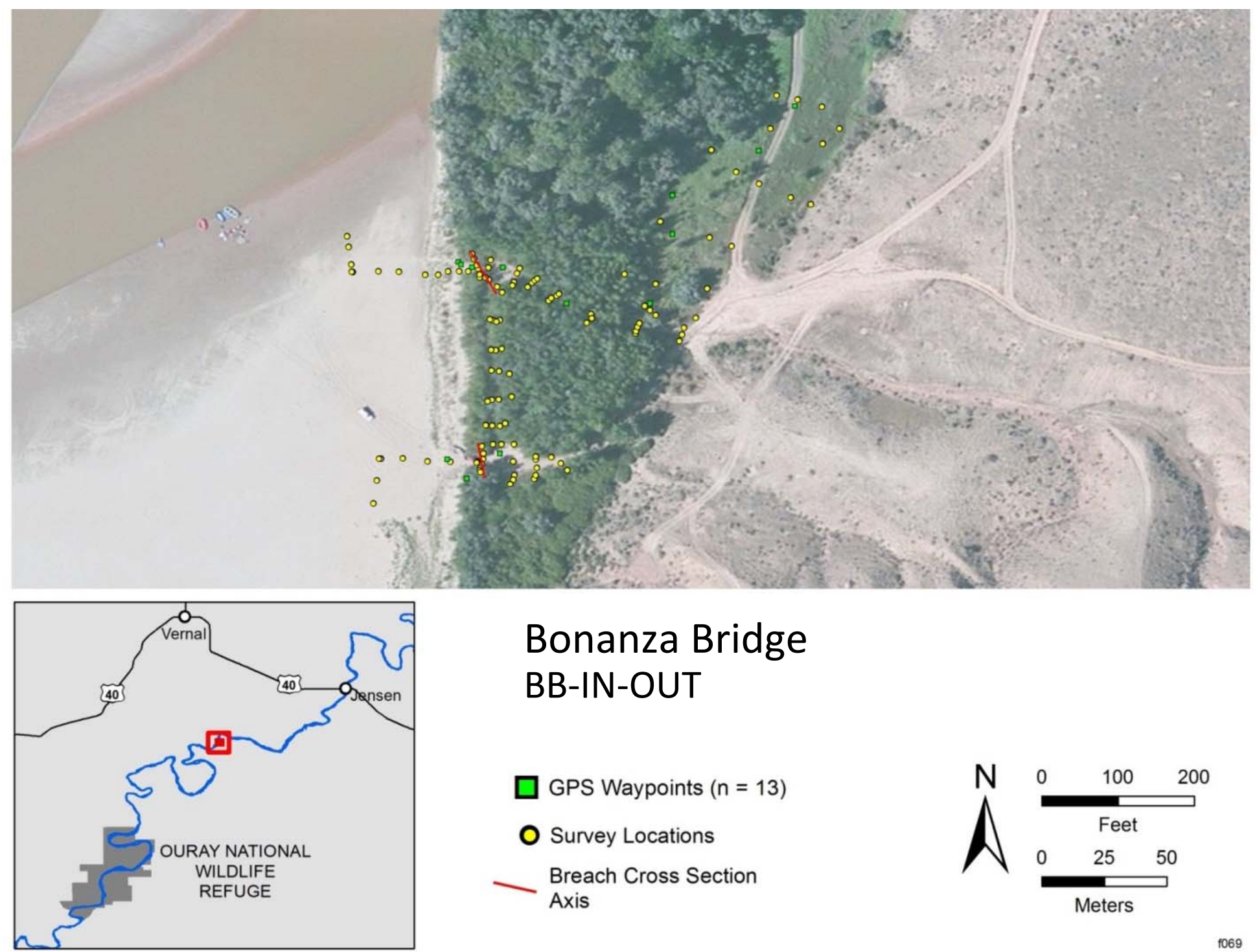

\section{Bonanza Bridge} BB-IN-OUT

$\square$ GPS Waypoints $(n=13)$

O Survey Locations

Breach Cross Section Axis

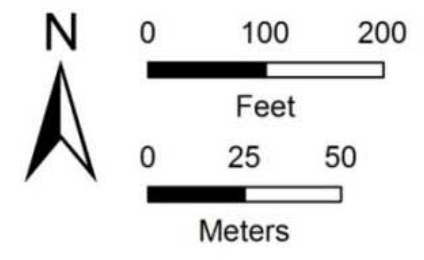

FIGURE 16 BB-OUT Survey Locations. The date of the aerial imagery differs from the date of the survey; aerial imagery does not depict exact conditions at the time of the survey. 
There is only one breach location at Stirrup (ST-OUT, Figure 17). A total of 193 locations were surveyed at ST-OUT (Figure 17). The estimated mean river water surface elevation at ST-OUT was 4,683.1 ft. Based on our survey, the breach and connection flows at ST-OUT in 2012 was estimated to be $11,000 \mathrm{cfs}$ and 16,900 cfs, respectively (Table 4), and the highest portion of the channel that limited connection was located approximately two-thirds of the way up the channel from the breach (Figure B-11). This estimated connection flow was approximately 3,900 cfs higher than the connection flow reported by Tetra Tech (2005). At the time of the survey, no deposits of loose sand or other material that might obstruct flow were seen. The estimated breach flow was lower than previous estimates, but Tetra Tech (2005) noted a decrease in elevation from previous surveys of about $1.5 \mathrm{ft}$ (Table 4). Estimated fish passage flow for ST-OUT in 2012 was 20,200 cfs, which is a 3,900 cfs increase from 2005 (Table 6).

\subsection{ABOVE BRENNAN}

The Above Brennan wetland was surveyed on October 22, 2012. Table 3 summarizes the dates and times of the surveys with corresponding lag-adjusted local flow conditions at the time of the survey. The local flow at Above Brennan at the time of the survey was calculated to be 1,180 cfs (Table 3 ).

Four breach locations were surveyed at Above Brennan: three upstream inlets and a downstream outlet (Figure 18). The approximate distance between the upstream-most inlet (AB-IN-1) and the outlet (AB-OUT) was 0.8 river mi (1.3 river $\mathrm{km})$. Characterizations of levee and floodplain connection elevations at each of these locations are provided below. As summarized in Table 5, the 2012 minimum connection flow at Above Brennan was estimated to be 9,990 cfs (AB-OUT), which was about a 3,010 cfs decrease from connection flow observations made by Tetra Tech (2005). Estimated 2012 connection flows among upstream breaches increased by about 3,400 cfs, whereas connection flows at the downstream breach (AB-OUT) decreased by about 3,010 cfs. Fish passage flow estimates for Above Brennan showed the same pattern as connection flow, but were on average 3,300 cfs higher (Table 6).

AB-IN-1. A total of 131 locations were surveyed at AB-IN-1 (Figure 19). The estimated mean river water surface elevation at $\mathrm{AB}-\mathrm{IN}-1$ was 4,673.5 ft. At the time of survey, AB-IN-1 was a fairly narrow breach and channel with little apparent obstruction to flow. Based on our survey, breach and connection flows at AB-IN-1 in 2012 were estimated to be $10,300 \mathrm{cfs}$ and $16,400 \mathrm{cfs}$, respectively (Table 4), and the highest portion of the channel that limited connection was located approximately one-third of the way up the channel from the breach (Figure B-12). This estimated connection flow was approximately 3,400 cfs higher than the connection flow reported by Tetra Tech (2005). The 2012 estimated breach flow was lower than previous estimates, but Tetra Tech (2005) noted a general trend in erosion at this site. The estimated fish passage flow for AB-IN-1 in 2012 was $19,700 \mathrm{cfs}$, which is a 3,400 cfs increase from 2005 (Table 6).

AB-IN-2. Fifty-four locations were surveyed at AB-IN-2 (Figure 20). The estimated mean river water surface elevation at AB-IN-2 was 4,673.2 ft. At the time of survey, AB-IN-2 was a very narrow channel (approximately $3 \mathrm{ft}$ wide) that widened as it approached the wetland. 


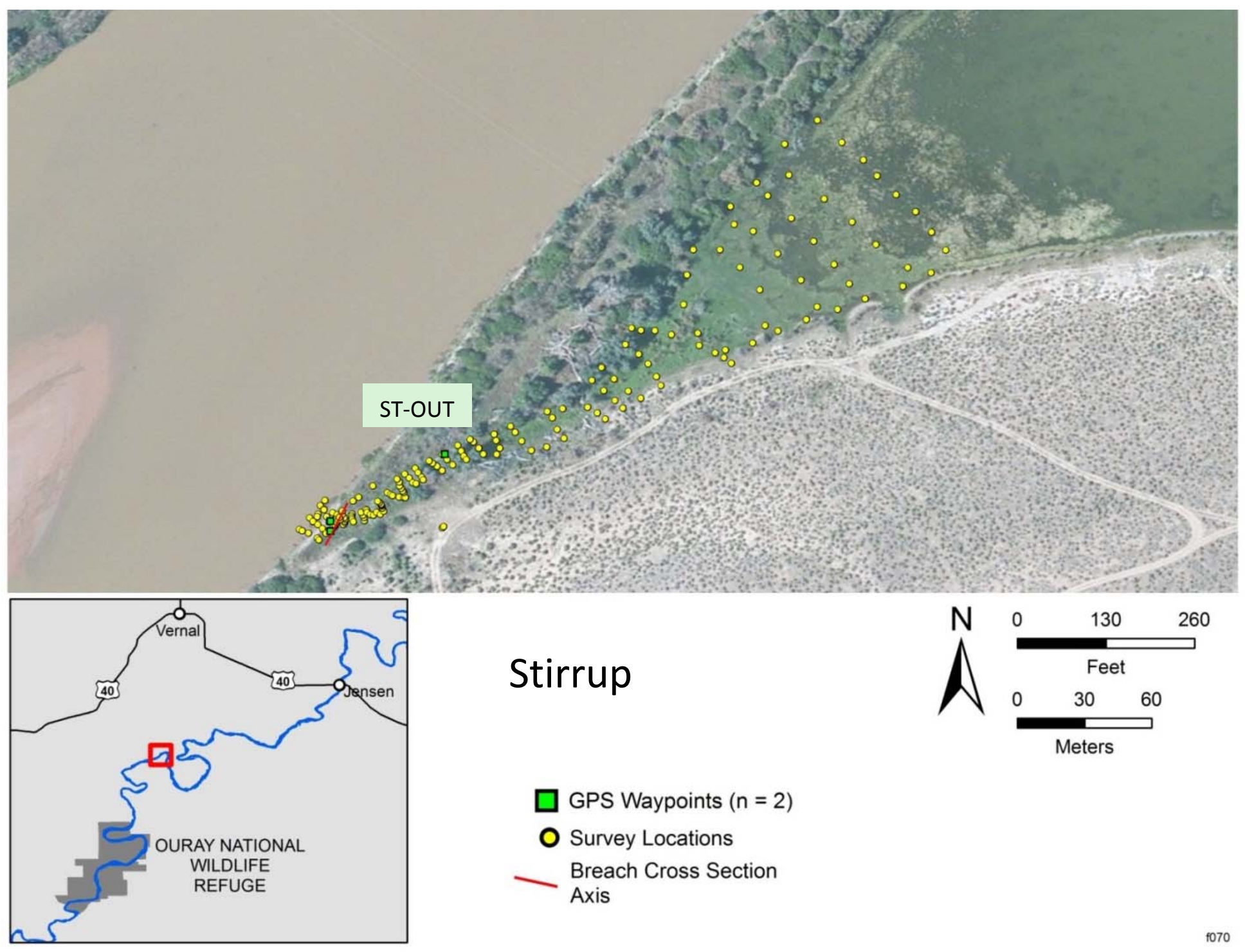

FIGURE 17 Stirrup Survey Locations. The date of the aerial imagery differs from the date of the survey; aerial imagery does not depict exact conditions at the time of the survey. 


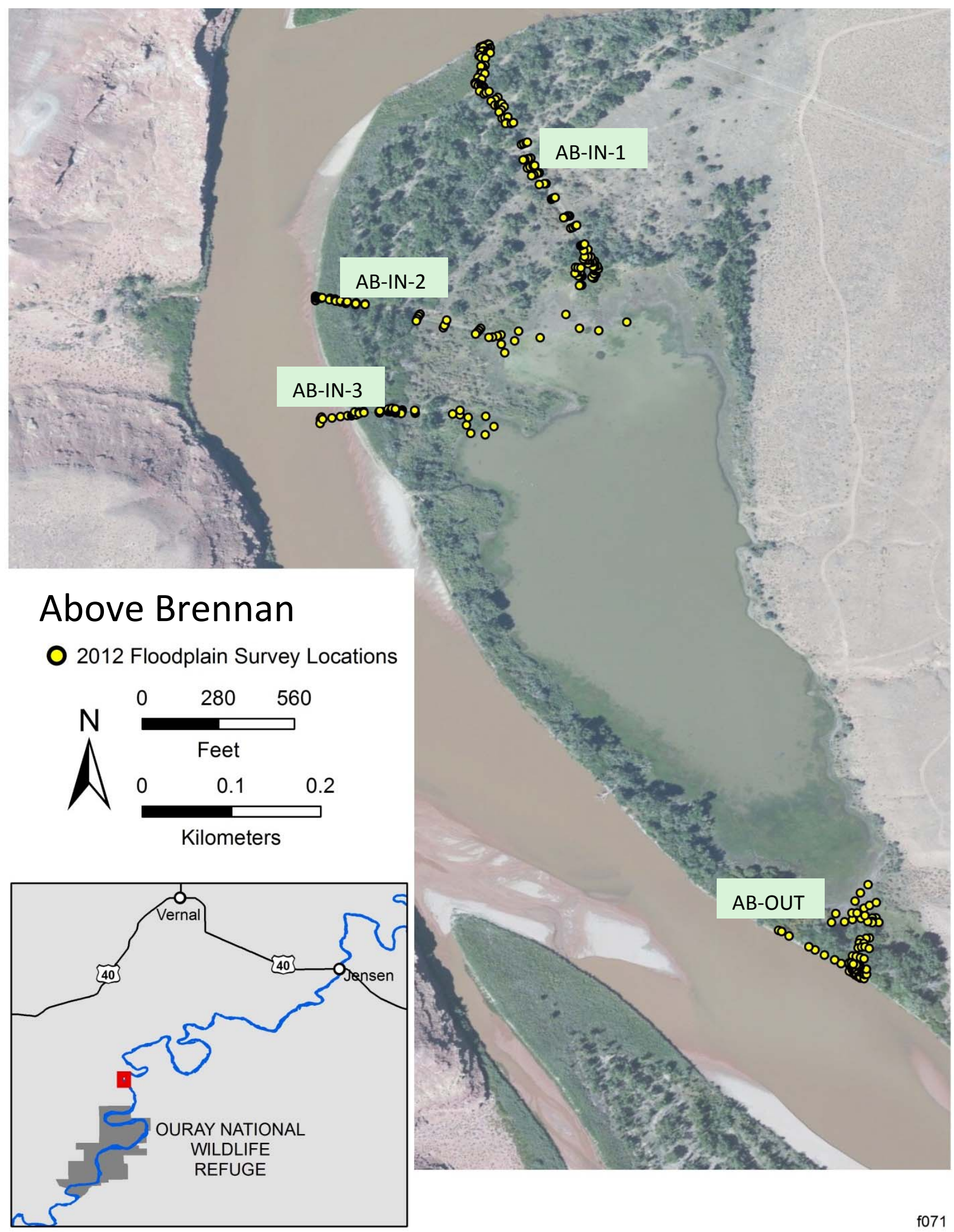

FIGURE 18 Above Brennan Survey Locations. The date of the aerial imagery differs from the date of the survey; aerial imagery does not depict exact conditions at the time of the survey. 


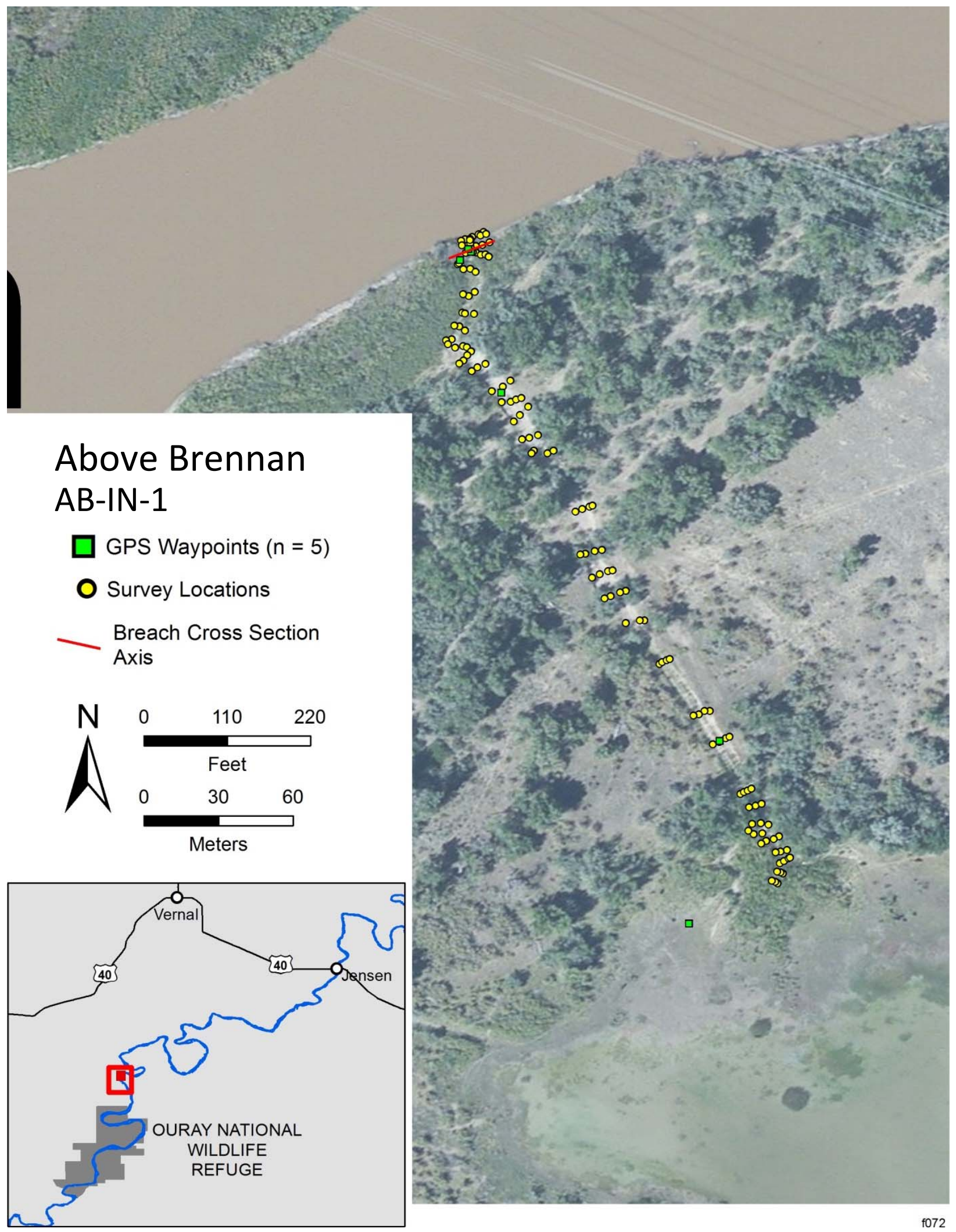

FIGURE 19 AB-IN-1 Survey Locations. The date of the aerial imagery differs from the date of the survey; aerial imagery does not depict exact conditions at the time of the survey. 

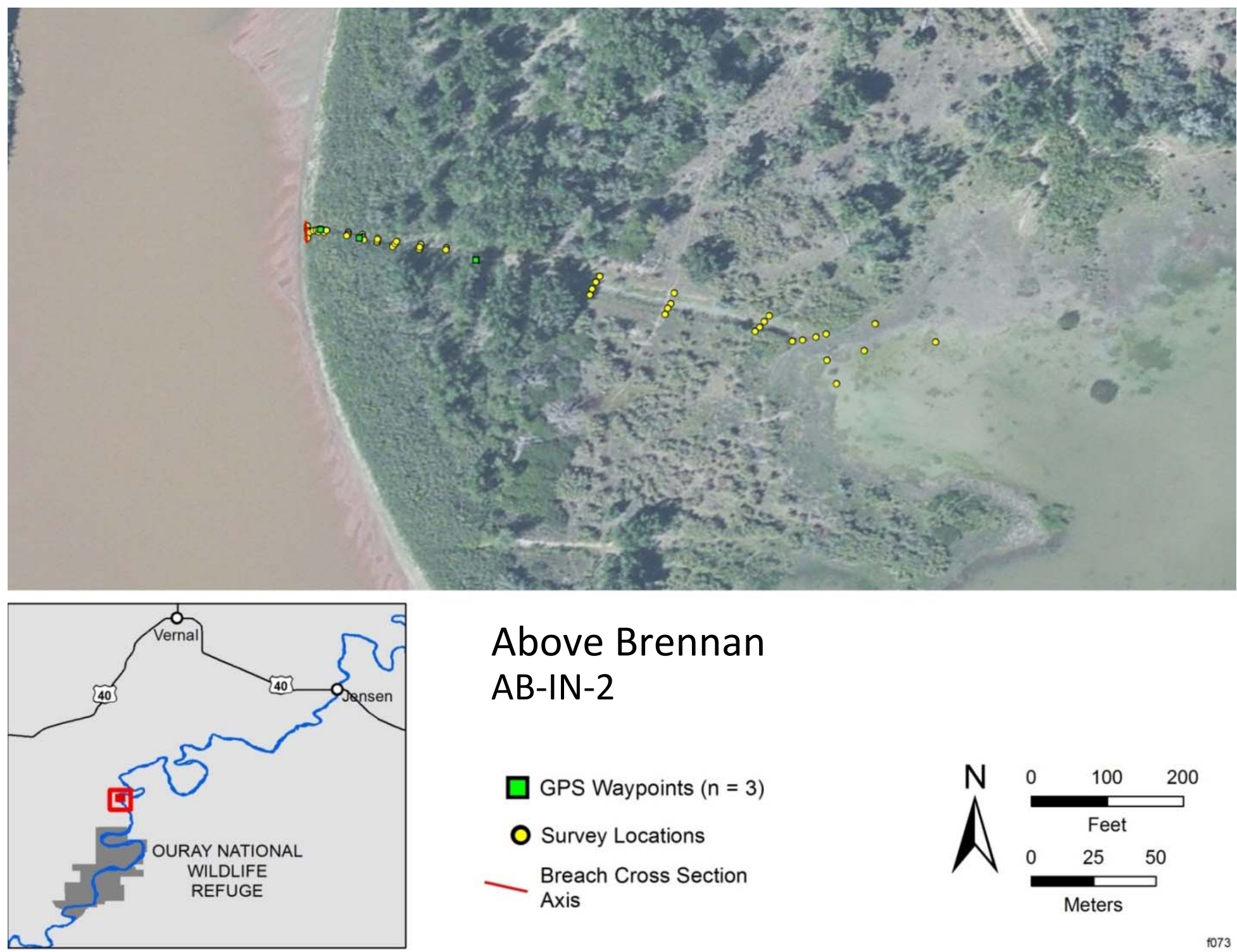

\section{Above Brennan}

AB-IN-2

$$
\begin{aligned}
& \square \text { GPS Waypoints }(n=3) \\
& \text { O Survey Locations } \\
& \text { Breach Cross Section } \\
& \text { Axis }
\end{aligned}
$$

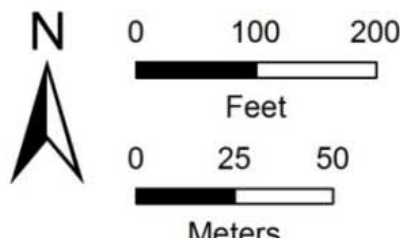

FIGURE 20 AB-IN-2 Survey Locations. The date of the aerial imagery differs from the date of the survey; aerial imagery does not depict exact conditions at the time of the survey. 
Based on our survey, the breach and connection flows at AB-IN-2 in 2012 were estimated to be $15,500 \mathrm{cfs}$ and 19,500 cfs, respectively (Table 4), and the highest portion of the channel that limited connection was located near the breach (Figure B-13). This estimated connection flow was approximately 6,500 cfs higher than the connection flows previously reported by Tetra Tech (2005). Tetra Tech (2005) did not observe any trends at this site. Estimated fish passage flow for AB-IN-2 in 2012 was 23,000 cfs, which is a 6,700 cfs increase from 2005 (Table 6).

AB-IN-3. Fifty-eight locations were surveyed at AB-IN-3 (Figure 21). The estimated mean river water surface elevation at AB-IN-3 was 4,672.9 ft. At the time of survey, AB-IN-3 was a narrow channel with packed sand. Based on our survey, the breach and connection flows at AB-IN-3 in 2012 were estimated to be $16,400 \mathrm{cfs}$ and 18,500 cfs, respectively (Table 4), and the highest portion of the channel that limited connection was located near the breach (Figure B-14). This estimated connection flow was approximately 5,500 cfs higher than the connection flows previously reported by Tetra Tech (2005). Tetra Tech (2005) noted a general trend of deposition at this site. The estimated fish passage flow for AB-IN-3 in 2012 was 21,900 cfs, which is a 5,600 cfs increase from 2005 (Table 6).

AB-OUT. Seventy-nine locations were surveyed at AB-OUT (Figure 22). The estimated mean river water surface elevation at AB-OUT was 4,672.5 ft. AB-OUT consisted of a fairly wide breach (approximately $45 \mathrm{ft}$ in width) with a narrow, more deeply incised notch. This breach led to a broad short channel with many downed trees that have collected near the outlet. This downed wood and a nearby degraded beaver dam could obstruct the inflow of water at high flows. Based on our survey, the breach and connection flows at AB-OUT in 2012 were both estimated to be $9,990 \mathrm{cfs}$ (Table 4), and the highest portion of the channel that limited connection was located near the breach (Figure B-15). This estimated connection flow was approximately 3,010 cfs lower than the connection flows reported by Tetra Tech (2005). Tetra Tech (2005) noted a general trend of erosion at this site. The fish passage flow for AB-OUT in 2012 was estimated to be $13,000 \mathrm{cfs}$, which is a 3,300 cfs decrease from 2005(Table 6).

\subsection{JOHNSON BOTTOM}

Johnson Bottom was surveyed on October 25, 2012. Table 3 summarizes the dates and times of the floodplain surveys with corresponding lag-adjusted local flow conditions at the time of the survey. The local flow at Johnson Bottom at the time of the survey was calculated to be 1,250 cfs (Table 3 ).

Two downstream breach locations were surveyed at Johnson Bottom (Figure 23). The approximate distance between the upstream-most breach (JB-OUT-1) and the downstream-most breach (JB-OUT-2) was 0.3 river mi ( 0.5 river $\mathrm{km})$. Characterizations of levee and floodplain elevations at each of these locations are provided below. As summarized in Table 5, the 2012 minimum connection flow at Johnson Bottom was estimated to be 16,100 cfs (JB-OUT-1), which was about a 3,100 cfs higher than the connection flow presented in Bestgen et al. (2011). Fish passage flow estimates for Johnson Bottom showed the same pattern as connection flow, but were on average 2,600 cfs higher (Table 6). 

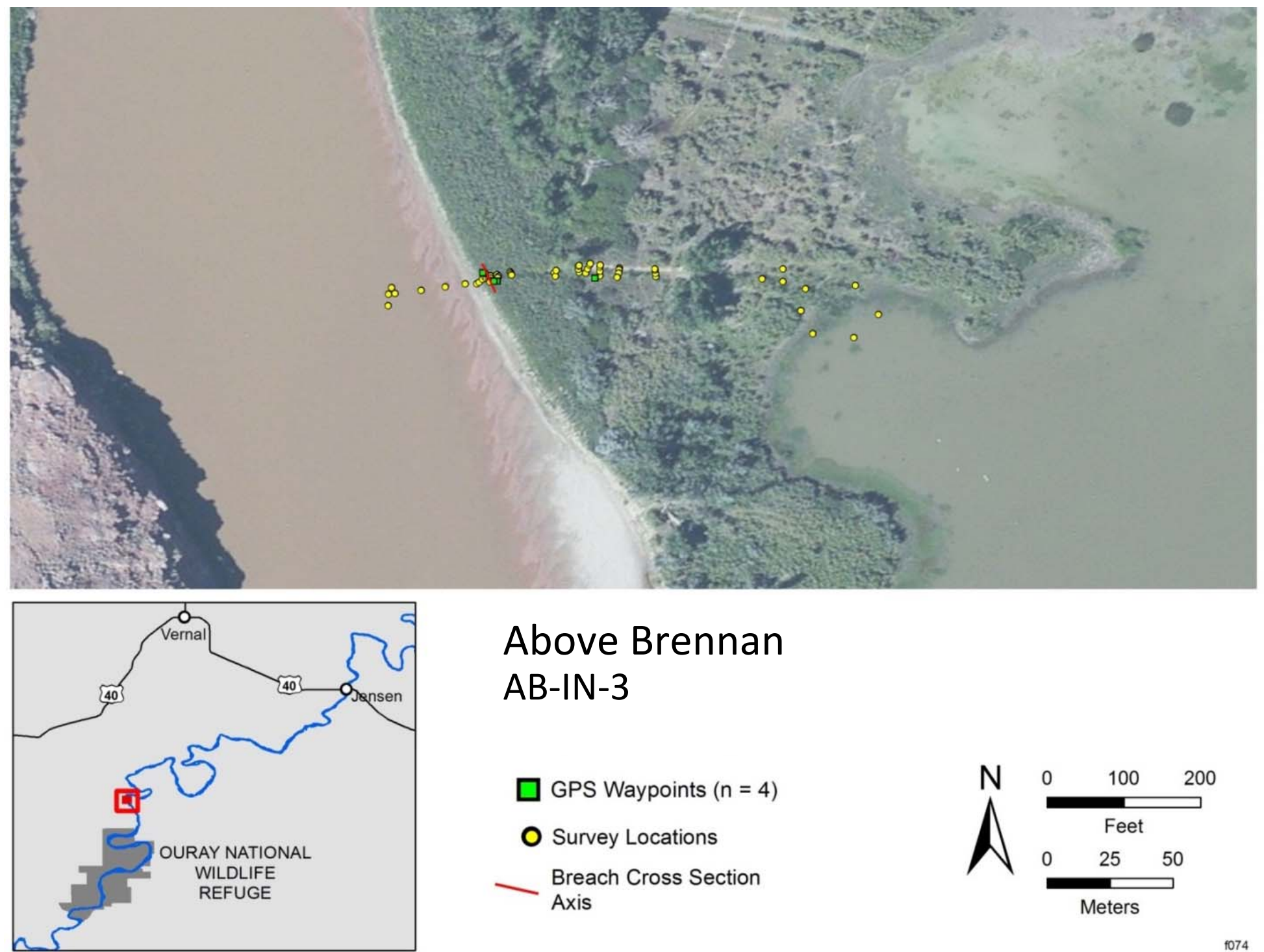

\section{Above Brennan}

\section{AB-IN-3}

$\square$ GPS Waypoints ( $n=4)$

O Survey Locations

Breach Cross Section
Axis

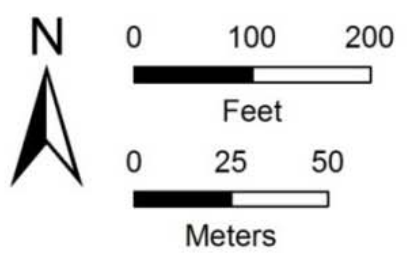

FIGURE 21 AB-IN-3 Survey Locations. The date of the aerial imagery differs from the date of the survey; aerial imagery does not depict exact conditions at the time of the survey. 

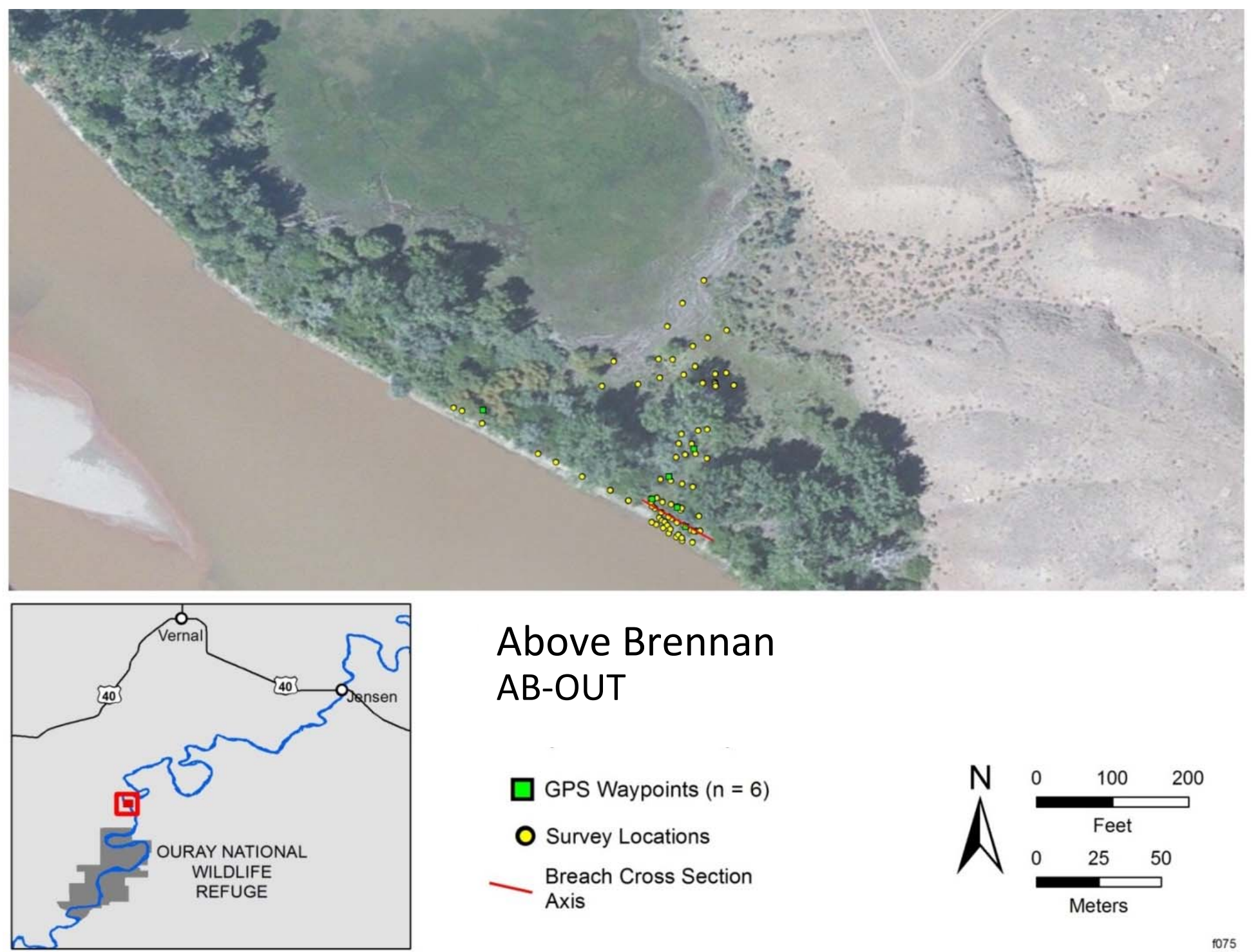

\section{Above Brennan AB-OUT}

$\square$ GPS Waypoints ( $n=6)$

O Survey Locations

Breach Cross Section

Axis

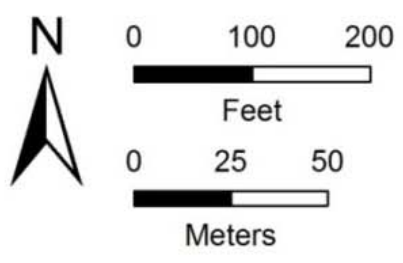

FIGURE 22 AB-OUT Survey Locations. The date of the aerial imagery differs from the date of the survey; aerial imagery does not depict exact conditions at the time of the survey. 

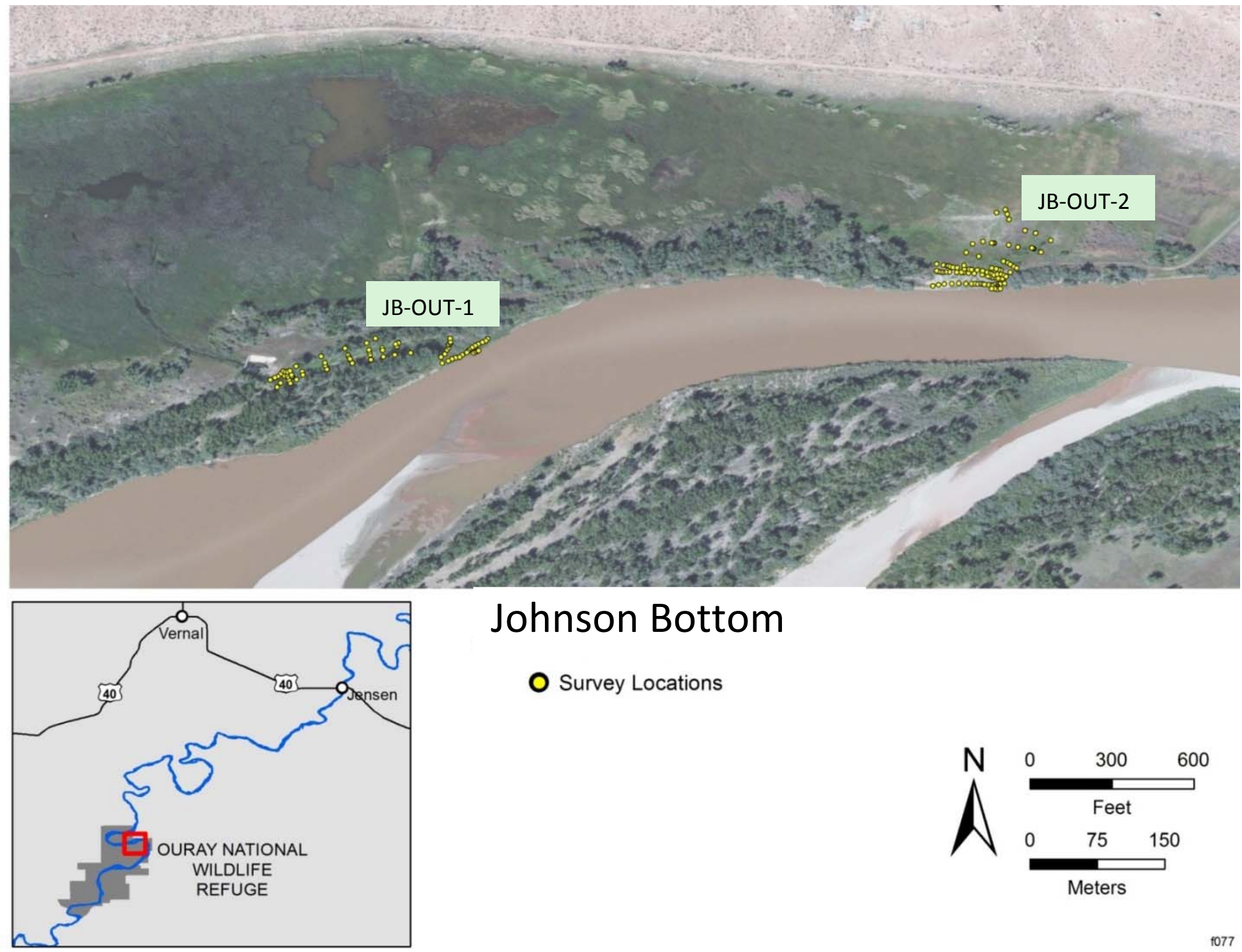

Johnson Bottom

O Survey Locations

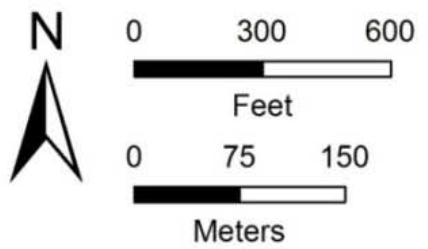

FIGURE 23 Johnson Bottom Survey Locations. The date of the aerial imagery differs from the date of the survey; aerial imagery does not depict exact conditions at the time of the survey. 
JB-OUT-1. JB-OUT-1 is a concrete and metal gated drain structure and fish kettle that was constructed in 1999 (Heitmeyer and Fredrickson 2005). Seventy-five locations were surveyed at the breach and connection channel leading to the JB-OUT-1 structure (Figure 24). The estimated mean river water surface elevation at JB-OUT-1 was 4,663.5 ft. JB-OUT-1 was a fairly narrow breach through hard sand that leads to a well-defined mostly vegetated channel that slopes down toward the gated inlet structure. Based on our survey, the breach and connection flows at JB-OUT-1 in 2012 were both estimated to be 16,100 cfs (Table 4), indicating that the breach represented the highest elevation along the connection channel (Figure B-16). Estimated connection flows in 2012 were approximately 3,100 cfs higher than the connection flows reported by Bestgen et al. (2011). The fish passage flow at JB-OUT-1 was estimated to be $18,700 \mathrm{cfs}$, which is a 3,300 cfs increase from 2005 (Table 6). Tetra Tech (2005) did not evaluate this site.

JB-OUT-2. JB-OUT-2 is a wide channel breach that was created when a $200 \mathrm{ft}$ portion of levee was removed in 1998 (Heitmeyer and Fredrickson 2005). Ninety-eight locations were surveyed at JB-OUT-2 (Figure 25). The estimated mean river water surface elevation at JBOUT-2 was 4,663.5 ft. This very broad low sandy breach led to a complex connection channel and the wetland. A sand road crosses the length of the breach. Based on our survey, the breach and connection flows at JB-OUT-2 in 2012 were estimated to be 11,100 cfs and 16,400 cfs, respectively (Table 4), and the highest portion of the channel that limited connection was located approximately half way up the channel from the breach (Figure B-17). This estimated connection flow was approximately 3,400 cfs higher than the connection flow reported by Bestgen et al. (2011). The increase in connection flow resulted from the accumulation of debris and sand deposits along the connection channel that, based on a review of aerial imagery, was deposited during the high peak flows of 2005 and 2011. The estimated fish passage flow for JB-OUT-2 in 2012 was 19,000 cfs, which is a 3,600 cfs increase from 2005 (Table 6). Tetra Tech (2005) did not evaluate this site.

\subsection{LEOTA BOTTOM}

Leota Bottom is separated into 11 units each with levees and water-control structures (Heitmeyer and Fredrickson 2005). Leota Bottom was surveyed on October 23, 2012. Table 3 summarizes the dates and times of the floodplain surveys with corresponding lag-adjusted local flow conditions at the time of the survey. The local flow at Leota Bottom at the time of the survey was calculated to be 1,190 cfs (Table 3).

Two downstream breach locations were surveyed at Leota Bottom: LB7-IN and LB7A-IN (Figure 26). In 1998, short portions of the levee along the Green River adjacent to units L7 and L7A were breached to allow flood flows of 15,000 to 20,000 cfs to enter Leota Bottom. The approximate distance between LB7-IN and LB7A-IN was 0.3 river mi ( 0.5 river $\mathrm{km})$. Characterizations of levee and floodplain elevations at each of these locations are provided below. As summarized in Table 5, the 2012 minimum connection flow at Leota Bottom was estimated to be 13,400 cfs (LB7A-IN). This wetland was not surveyed by Tetra Tech (2005) or reported in Bestgen et al. (2011); therefore, comparisons to 2005 connection flows could not be 

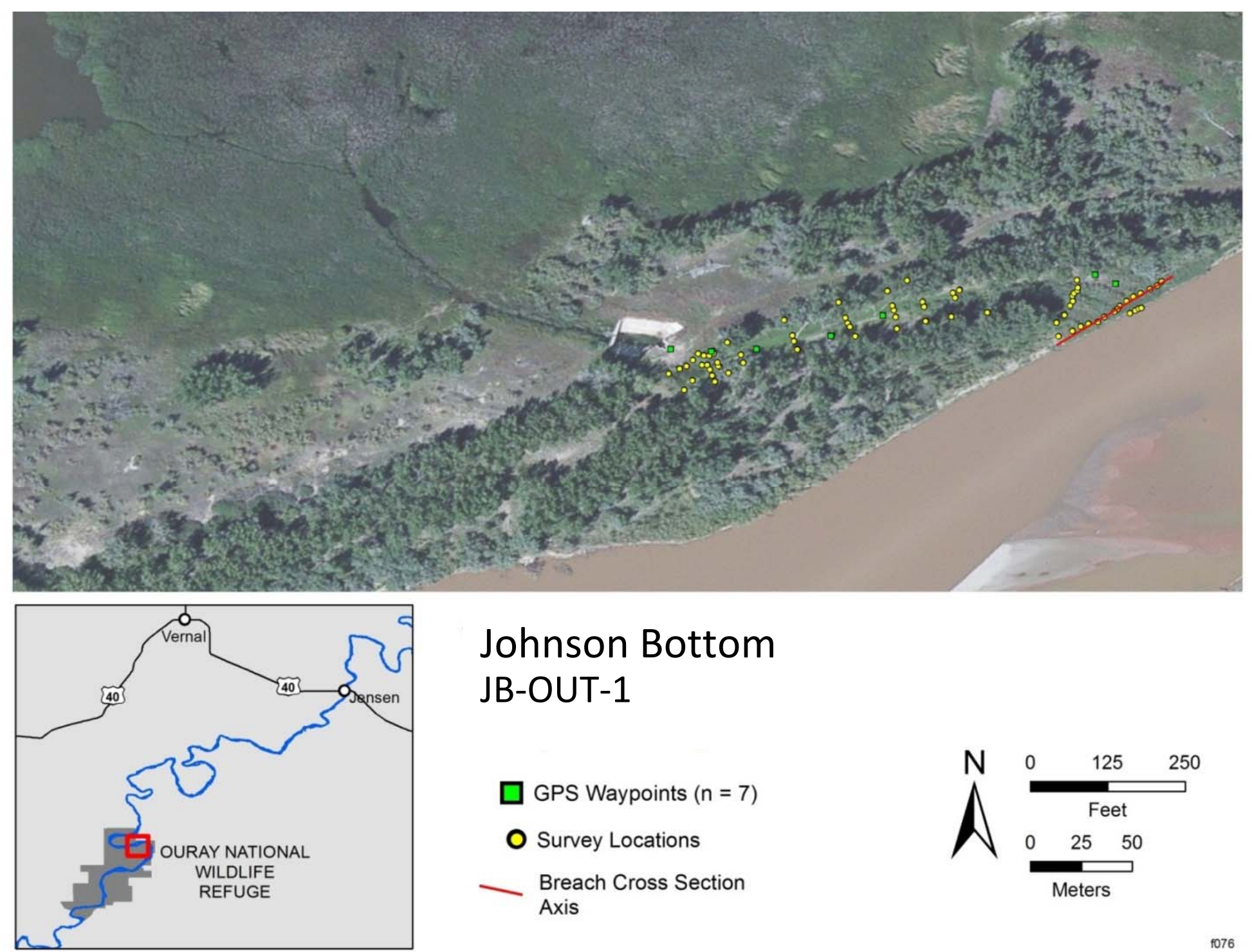

\section{Johnson Bottom} JB-OUT-1

GPS Waypoints $(n=7)$

O Survey Locations

- Breach Cross Section

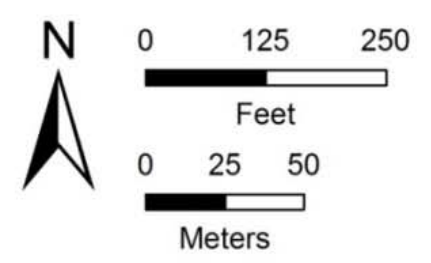

FIGURE 24 JB-OUT-1 Survey Locations. The date of the aerial imagery differs from the date of the survey; aerial imagery does not depict exact conditions at the time of the survey. 

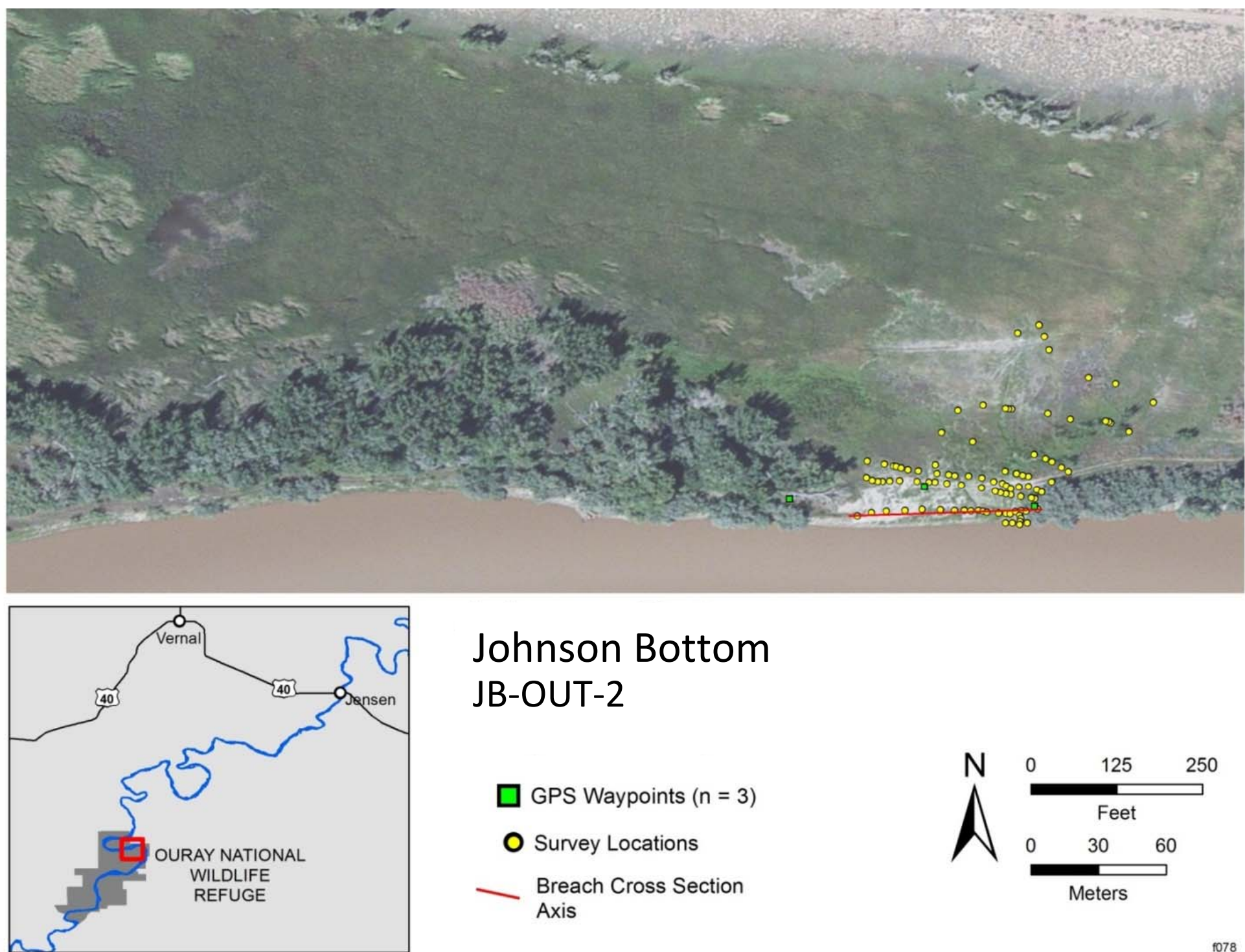

\section{Johnson Bottom} JB-OUT-2

GPS Waypoints $(n=3)$

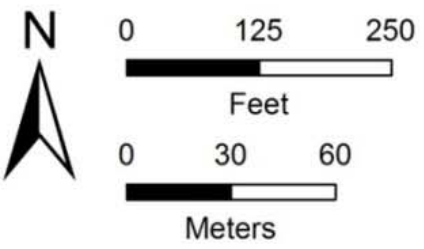

FIGURE 25 JB-OUT-2 Survey Locations. The date of the aerial imagery differs from the date of the survey; aerial imagery does not depict exact conditions at the time of the survey. 

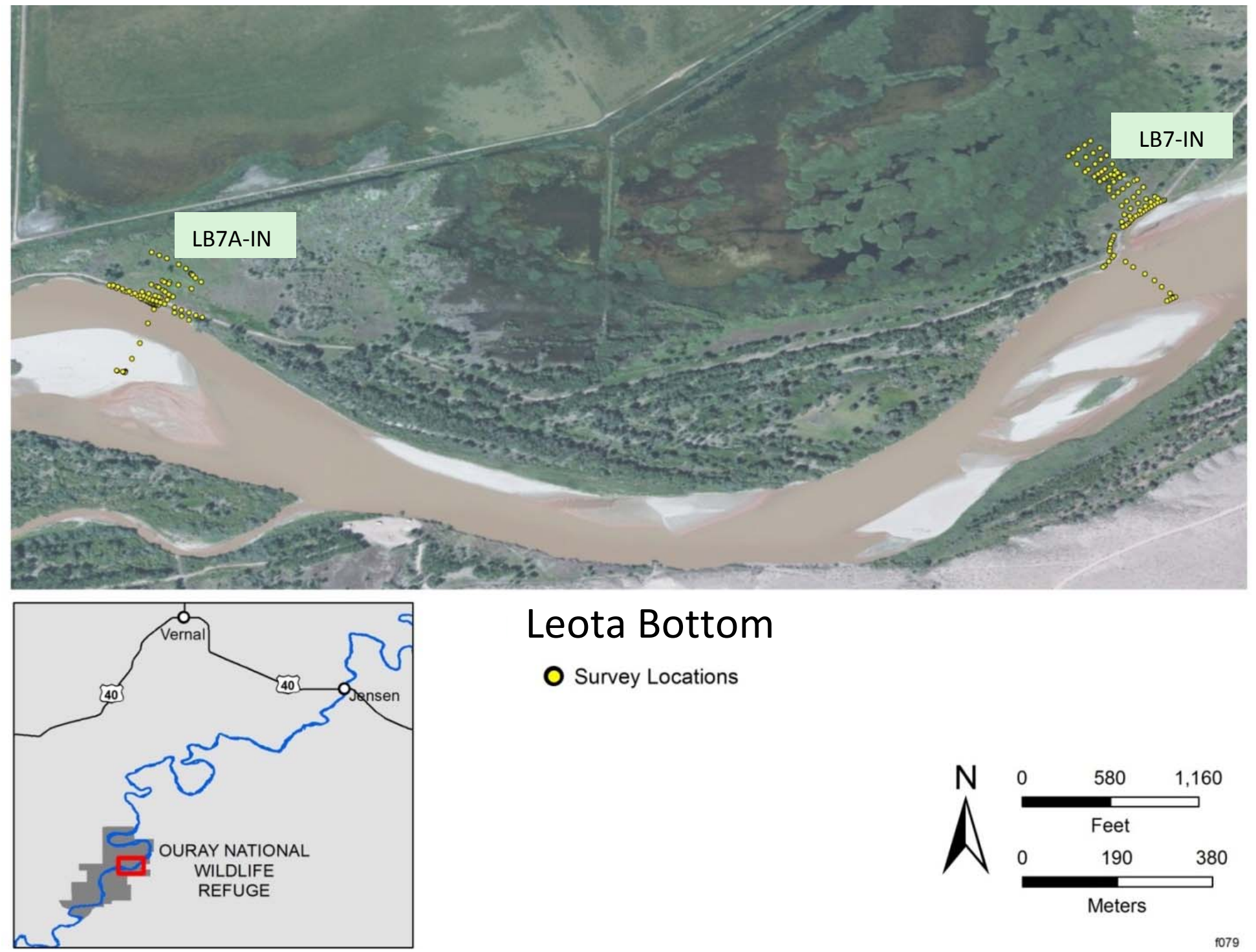

Leota Bottom

O Survey Locations

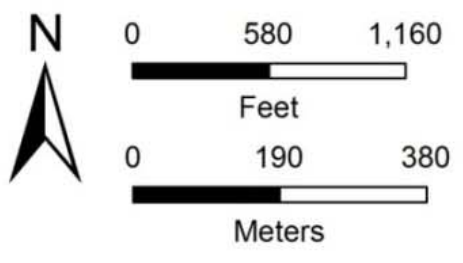

FIGURE 26 Leota Bottom Survey Locations. The date of the aerial imagery differs from the date of the survey; aerial imagery does not depict exact conditions at the time of the survey. 
made. Fish passage flow estimates for Leota Bottom showed the same pattern as connection flow, but were on average 2,550 cfs higher (Table 6).

LB7-IN. Ninety-seven locations were surveyed at LB7-IN (Figure 27). The estimated mean river water surface elevation at LB7-IN was 4,659.9 ft. LB7-IN was a broad breach of loose sand that led to a broad connection channel to the wetland; a sand road traversed the length of the breach. There was a large sandbar between the breach and the river edge. Based on our survey, the breach and connection flows at LB7-IN were estimated to be 17,200 cfs and 17,600 cfs, respectively (Table 4), and the highest portion of the channel that limited connection was located near the wetland edge (Figure B-18). This breach was not surveyed by Tetra Tech (2005) or reported in Bestgen et al. (2011); therefore, comparisons to 2005 connection flows could not be made. In 2012, a large deposit of sand within the connection channel was apparent from the 2011 inflow. The estimated fish passage flow for LB7-IN in 2012 was 20,300 cfs (Table 6).

LB7A-IN. Eighty-two locations were surveyed at LB7A-IN (Figure 28). The estimated mean river water surface elevation at LB7A-IN was 4,658.8 ft. LB7A-IN was a broad breach that led to a broad connection channel to the wetland; a road traversed the length of the breach, part of which was paved concrete with the rest loose sand. There was a large sandbar between the breach and the river edge. Based on our survey, the breach and connection flows at LB7A-IN in 2012 were estimated to be 13,300 cfs and 13,400 cfs, respectively (Table 4), and the highest portion of the channel that limited connection was located near the wetland edge (Figure B-19). This breach was not surveyed by Tetra Tech (2005) or reported in Bestgen et al. (2011); therefore, comparisons to 2005 connection flows could not be made. The estimated fish passage flow for LB7A-IN in 2012 was 15,800 cfs (Table 6).

\subsection{SHEPPARD BOTTOM}

Sheppard Bottom was surveyed on October 24, 2012. Table 3 summarizes the dates and times of the floodplain surveys with corresponding lag-adjusted local flow conditions at the time of the survey. The local flow at Sheppard Bottom at the time of the survey was calculated to be 1,190 cfs (Table 3).

One downstream breach location was surveyed at Sheppard Bottom (Figure 29). Tetra Tech (2005) did not evaluate this site (Table 4). This location was identified by the Ouray National Wildlife Refuge Manager (D. Shaad) as a potential connection recently created by the Refuge to facilitate connection during peak runoff. Twenty-four locations were surveyed at SB-IN (Figure 29). No river water surface elevations were recorded at Sheppard Bottom because of the distance to the river from the breach and the lack of access to the river's edge. Instead, river water surface elevations were interpolated from the nearest upstream survey location (LB7A-IN) and downstream survey location (OC-OUT-1). Based upon this interpolation, the estimated water surface elevation at SB-IN was calculated to be 4,651.74 ft. Based on our survey, the breach flow at SB-IN in 2012 was estimated to be 11,800 cfs. However, because the surveyed breach was far from the river (straight line distance $0.25 \mathrm{mi}$ ), and no clear connection channel led to the river, we did not survey the area between the breach and the river (Figure 29). 

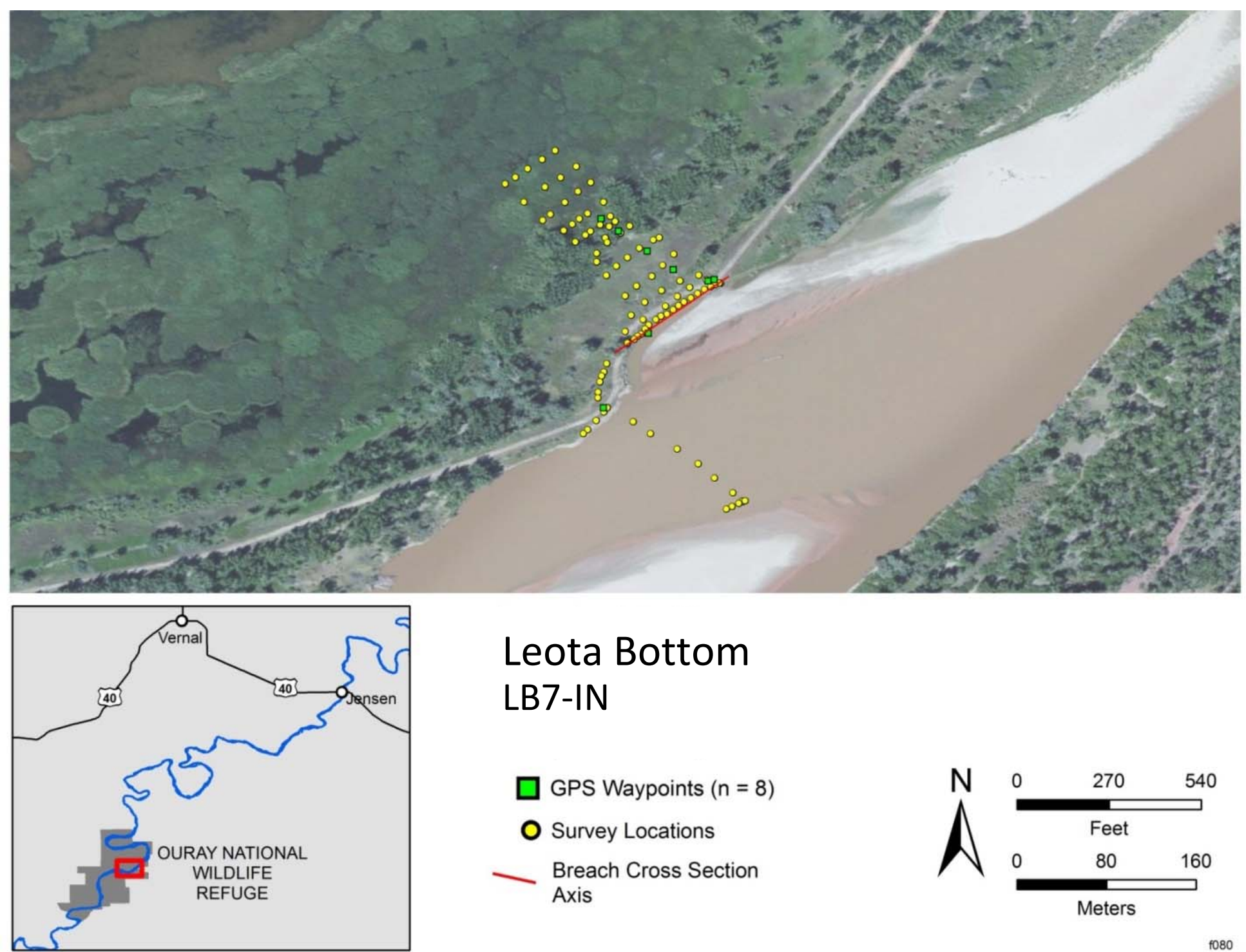

\section{Leota Bottom}

\section{LB7-IN}

$\square$ GPS Waypoints $(n=8)$

O Survey Locations

Breach Cross Section

Axis

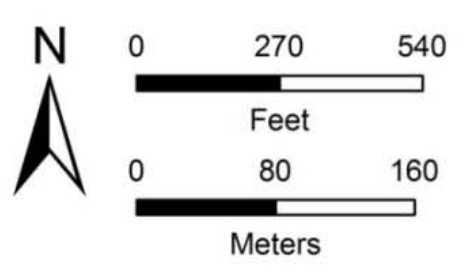

f080

FIGURE 27 LB7-IN Survey Locations. The date of the aerial imagery differs from the date of the survey; aerial imagery does not depict exact conditions at the time of the survey. 

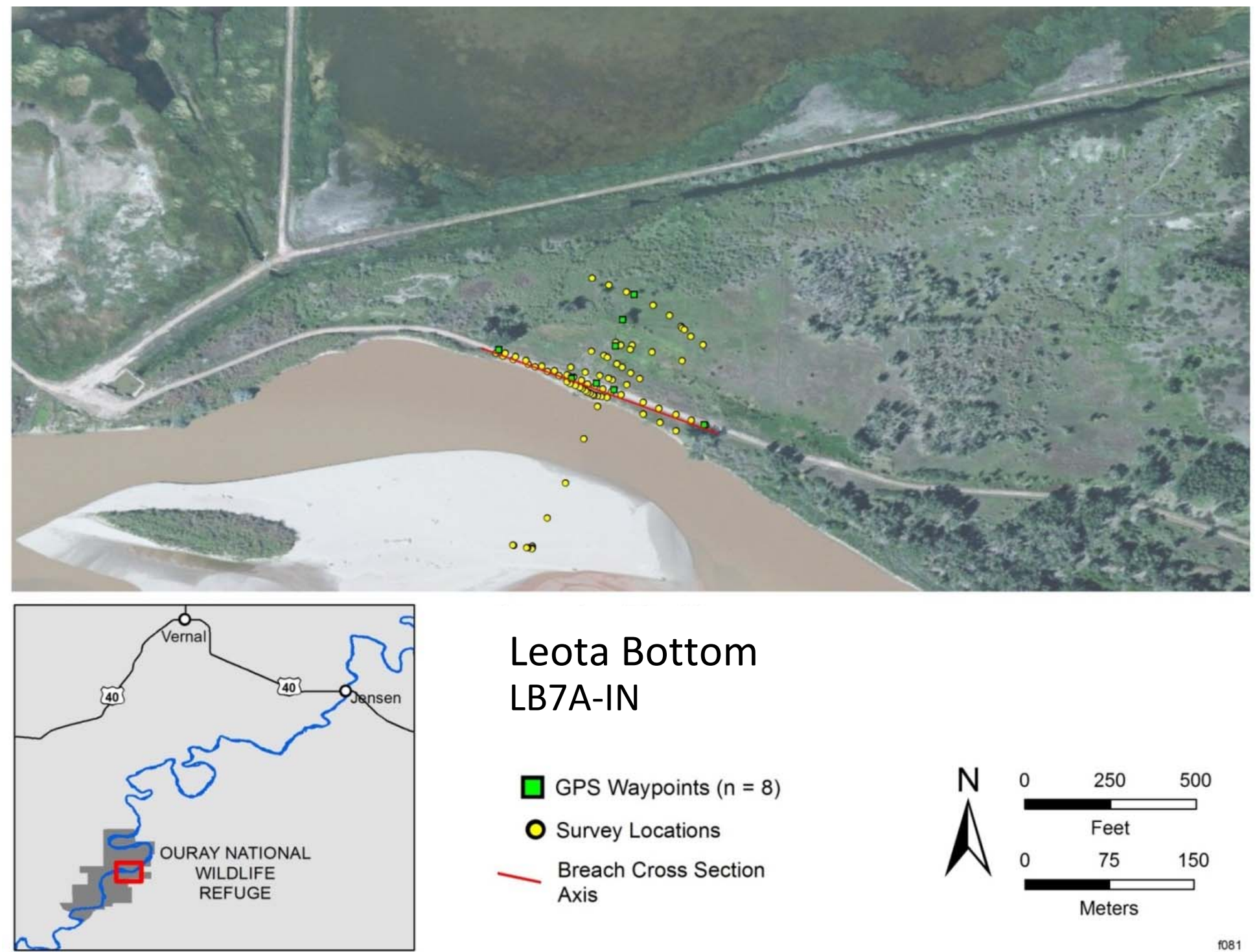

\section{Leota Bottom} LB7A-IN

$\square$ GPS Waypoints $(n=8)$

O Survey Locations

Breach Cross Section Axis

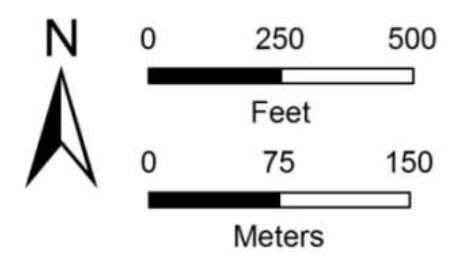

FIGURE 28 LB7A-IN Survey Locations. The date of the aerial imagery differs from the date of the survey; aerial imagery does not depict exact conditions at the time of the survey. 

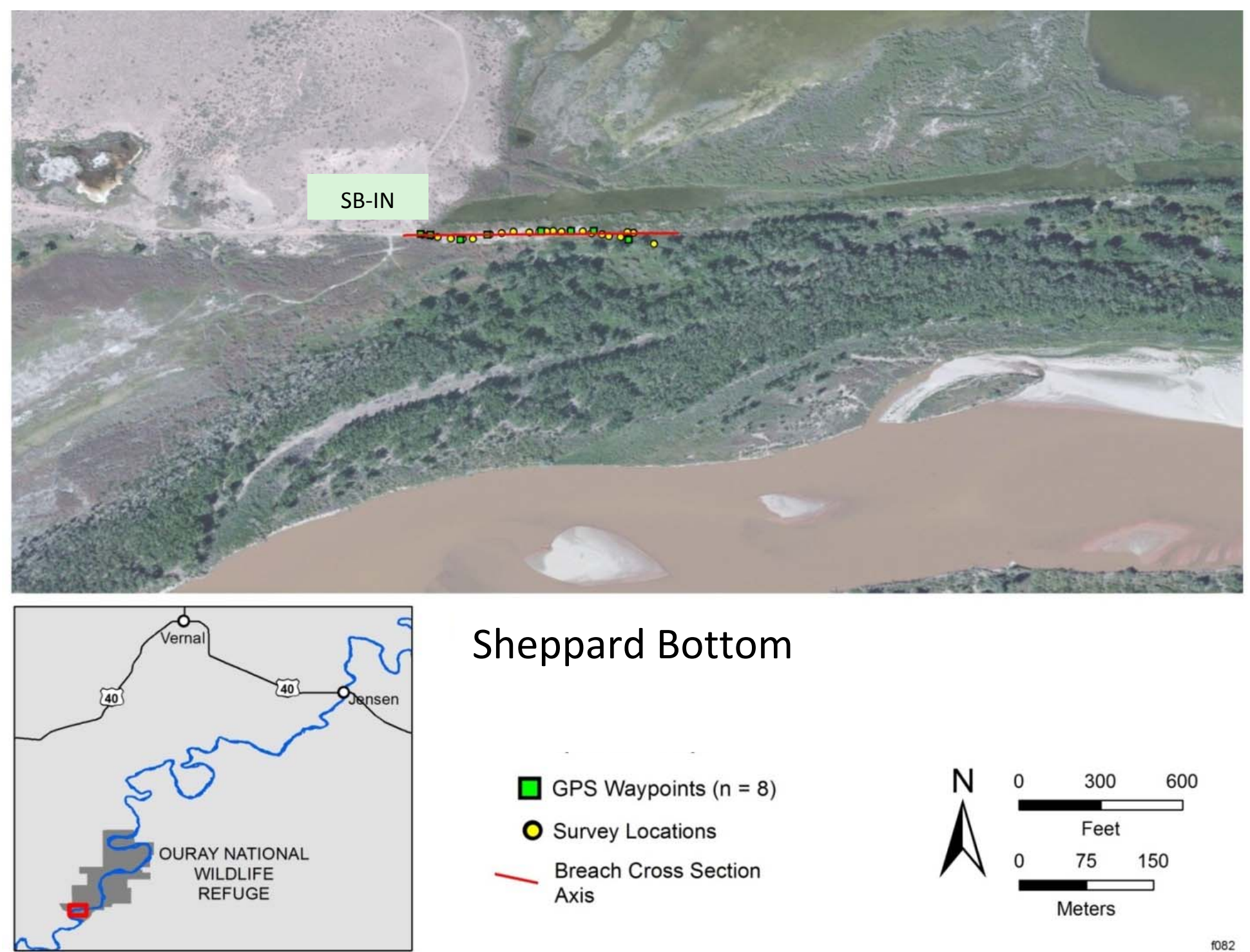

\title{
Sheppard Bottom
}

\author{
$\square$ GPS Waypoints $(n=8)$ \\ O Survey Locations \\ Breach Cross Section \\ Axis
}

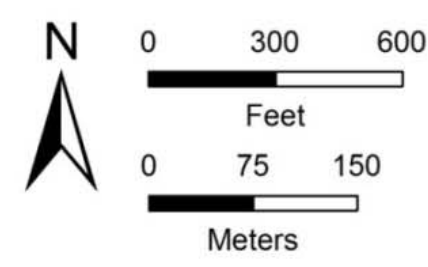

f082

FIGURE 29 Sheppard Bottom Survey Locations. The date of the aerial imagery differs from the date of the survey; aerial imagery does not depict exact conditions at the time of the survey. 
Refuge staff (D. Shaad, personal communication) noted that Sheppard Bottom did not connect through this breach in 2014 when flows reached 17,800 cfs at the Ouray gage on June 9, indicating that obstruction to inflow does occur somewhere between the breach and the river, and that connection flow is considerably higher than the breach flow at this location. A more extensive survey would be needed to identify the most likely connection channel between the river and wetland.

\subsection{OLD CHARLIE WASH}

Old Charlie Wash (referred to as Woods Bottom in Heitmeyer and Fredrickson 2005) was surveyed on October 24, 2012. Table 3 summarizes the dates and times of the floodplain surveys, with corresponding lag-adjusted local flow conditions at the time of the survey. The local flow at Old Charlie Wash at the time of the survey was calculated to be 1,190 cfs (Table 3).

Two downstream breach locations were surveyed at Old Charlie Wash (Figure 30). The approximate distance between OC-OUT-1 and OC-OUT-2 was 0.3 river mi $(0.5$ river km). Characterizations of levee and floodplain elevations at each of these locations are provided below. As summarized in Table 5, the 2012 minimum connection flow at Old Charlie Wash was estimated to be 9,430 cfs (OC-OUT-2), which is 3,570 cfs lower than the connection flow reported in Bestgen et al. (2011). Fish passage flow estimates for Leota Bottom showed the same pattern as connection flow, but were on average 2,285 cfs higher (Table 6).

OC-OUT-1. In 1997, a 100-ft-wide section of the south levee of the backside unit along the Green River was removed to allow overbank flooding at about 13,000 cfs. Fifty-two locations were surveyed at OC-OUT-1 (Figure 31). The estimated mean river water surface elevation at OC-OUT-1 was 4,650.5 ft. Based on our survey, the breach and connection flows at OC-OUT-1 in 2012 was estimated to be $12,400 \mathrm{cfs}$ and 14,300 cfs, respectively (Table 4), and the highest portion of the channel that limited connection was located approximately half way up the channel from the breach (Figure B-20). This estimated connection flow was approximately 1,300 cfs higher than the connection flow reported by Bestgen et al. (2011). The fish passage flow at OC-OUT-1 in 2012 was estimated to be 16,700 cfs, which is a 1,300 cfs increase from 2005 (Table 6).

OC-OUT-2. OC-OUT-2 is a concrete and metal gated drain structure that was modified in 1993 with a fish kettle and a bottom elevation of about 4,000 cfs (Heitmeyer and Fredrickson 2005). This breach to Old Charlie Wash can be opened or closed to allow river water to enter the site or be retained as river flows recede. Forty three locations were surveyed at OC-OUT-2 (Figure 32). The estimated mean river water surface elevation at OC-OUT-2 was 4,650.2 ft. Based on our survey, the estimated breach and connection flows at OC-OUT-2 in 2012 were approximately 3,850 cfs and 9,430 cfs, respectively (Table 4), and the highest portion of the channel that limited connection was about one-third of the distance between the river edge and the gate structure (Figure B-21). This connection flow is 3,570 cfs lower than the connection 


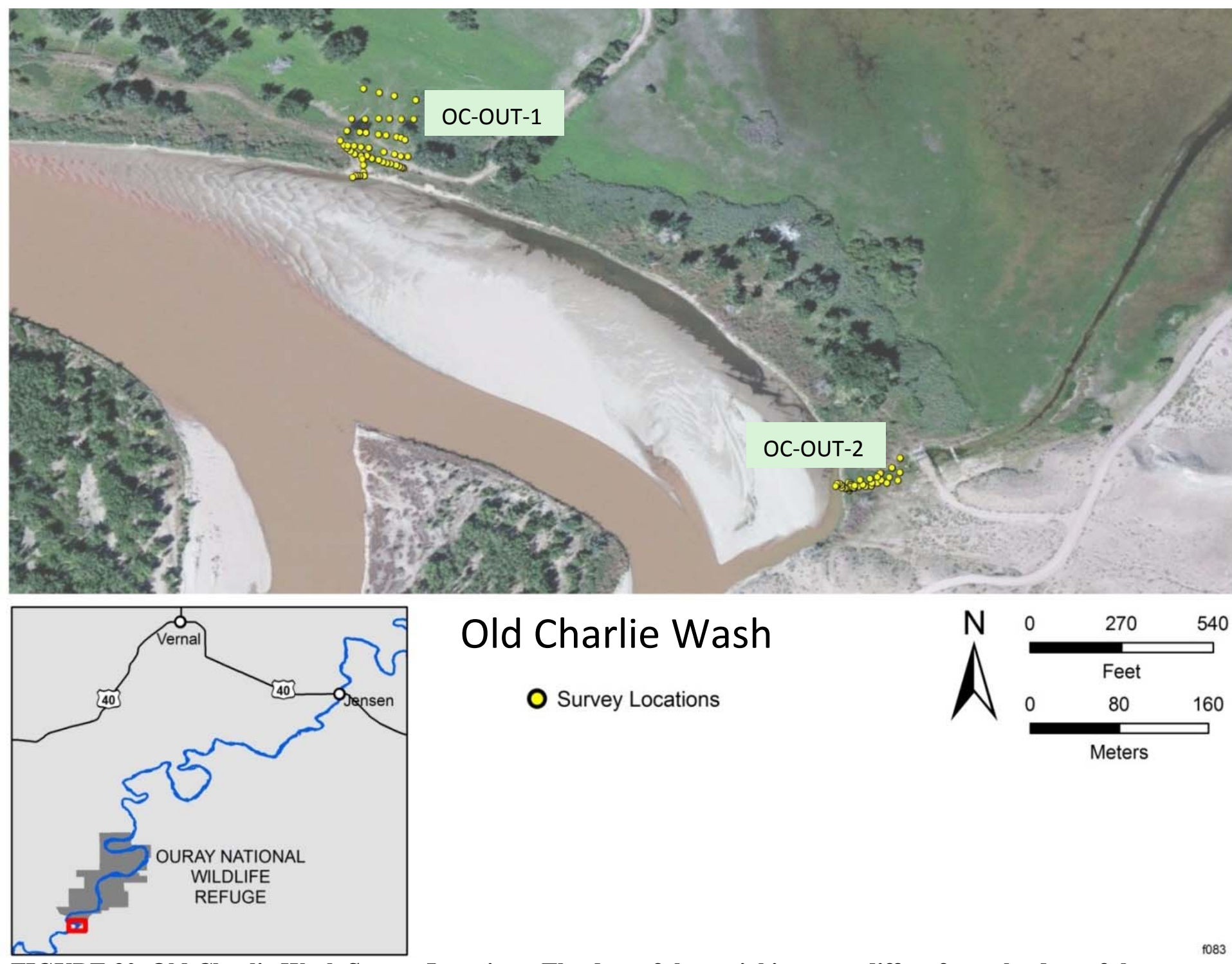

FIGURE 30 Old Charlie Wash Survey Locations. The date of the aerial imagery differs from the date of the survey; aerial imagery does not depict exact conditions at the time of the survey. 

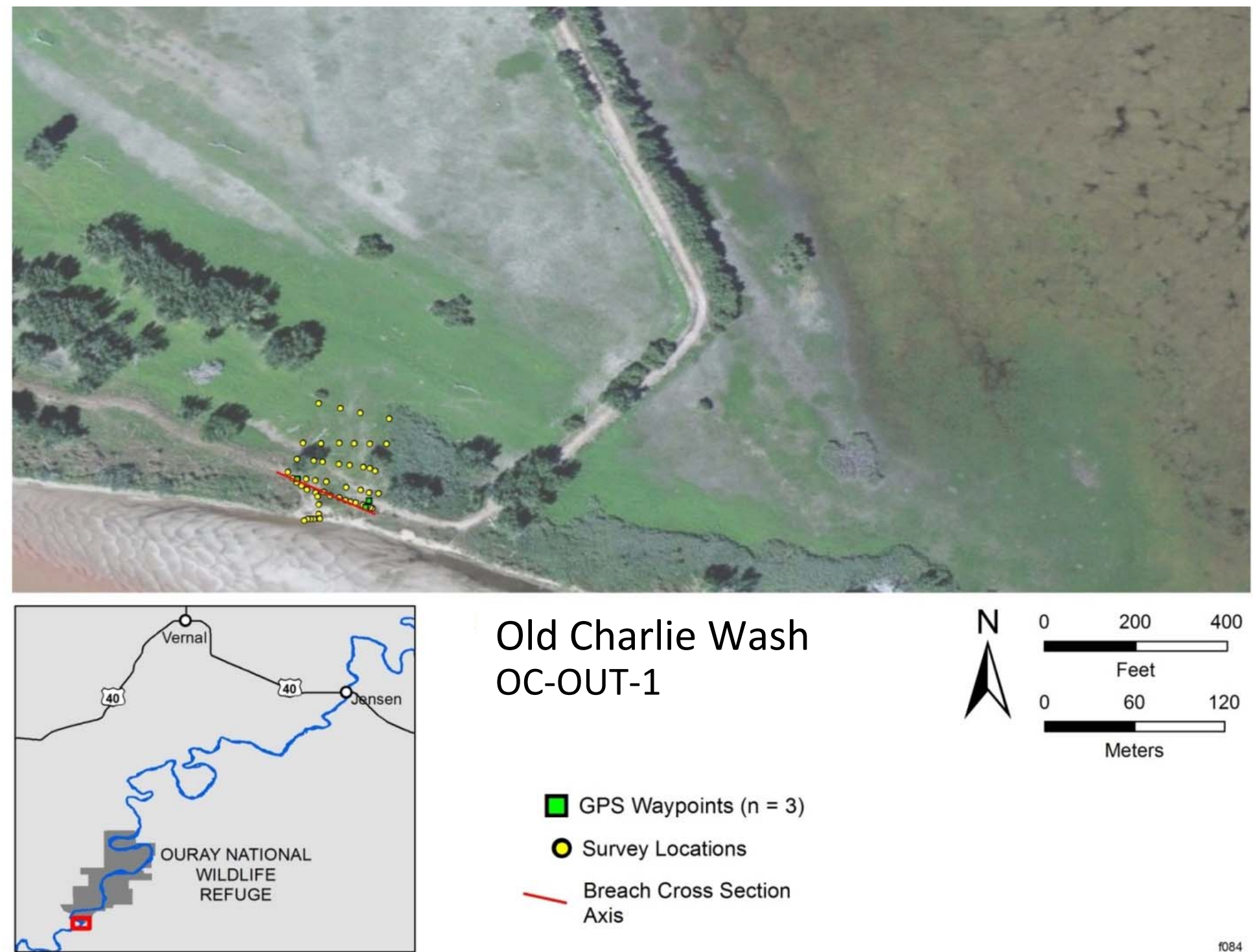

FIGURE 31 OC-OUT-1 Survey Locations. The date of the aerial imagery differs from the date of the survey; aerial imagery does not depict exact conditions at the time of the survey. 

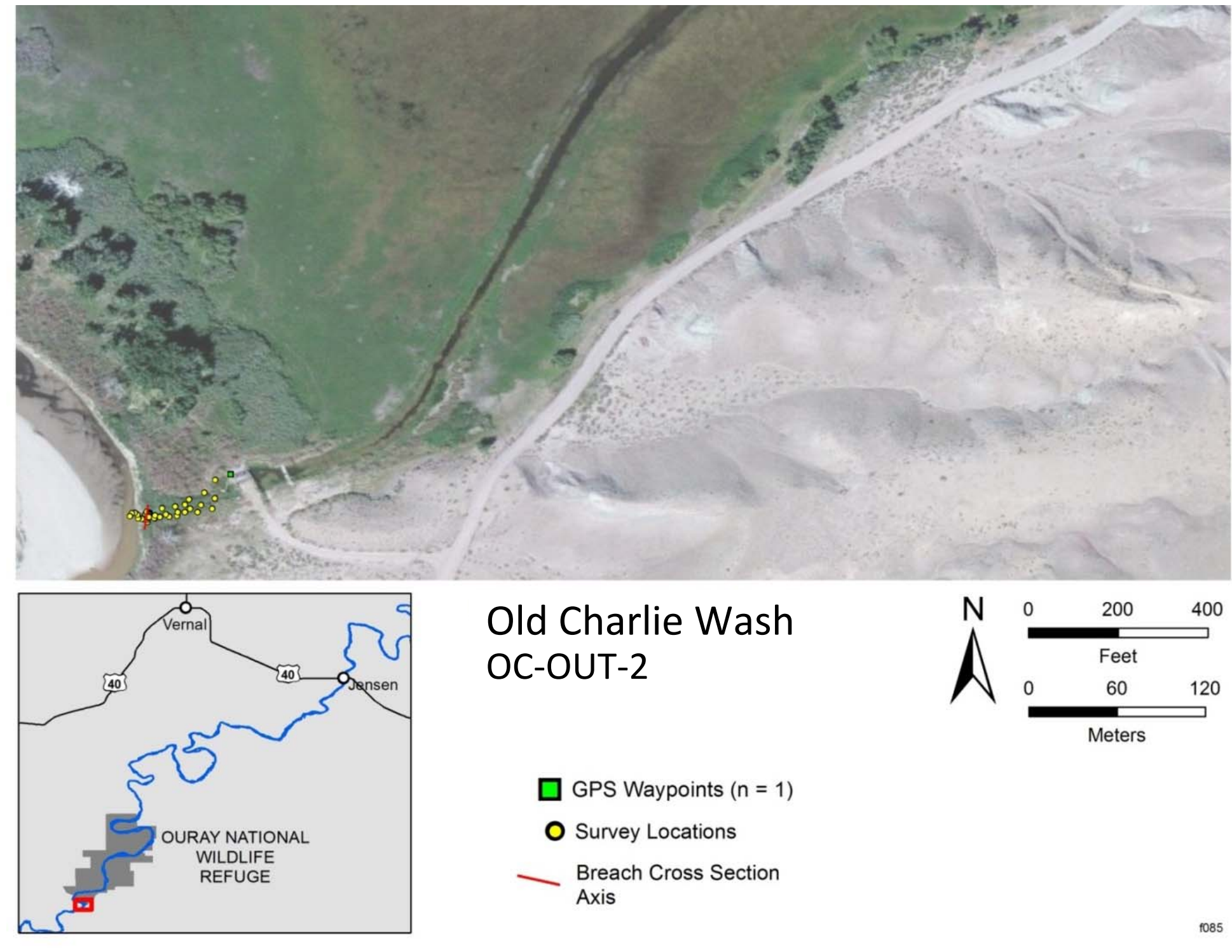

FIGURE 32 OC-OUT-2 Survey Locations. The date of the aerial imagery differs from the date of the survey; aerial imagery does not depict exact conditions at the time of the survey.

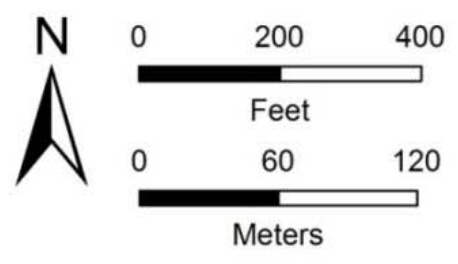

\section{$\square$ GPS Waypoints $(\mathrm{n}=1)$ \\ O Survey Locations}

Breach Cross Section

Axis 
flow reported by Bestgen et al. (2011). The estimated fish passage flow at the gate structure in 2012 was estimated to be $11,600 \mathrm{cfs}$, which is a 3,800 cfs decrease from 2005 (Table 6).

\subsection{RESULTS SUMMARY}

Our 2012 survey identified substantial changes since 2005 at most of the levee breaches and connection channels evaluated (Table 4). Original reported values were largely based on design specifications of levee breaches made to intentionally entrain water at specific high flows. However, as noted by Tetra Tech (2005) during the high flows of 2005, there were inconsistencies in the design connection flow and the actual connection flow at several of the Bonanza Bridge breaches (BB-IN-1, BB-IN-2, BB-OUT); each of these breaches did not connect until flows were higher than the design flow (Table 4).

The average estimated minimum floodplain connection flow (i.e., the lowest connection flow of any breach at a particular wetland) among the seven floodplain wetlands surveyed in 2012 was 13,503 cfs (Table 5). This is a relatively small mean increase ( $826 \mathrm{cfs}$ ) compared to estimated connection flows in 2005. However, there was considerable variation among the wetlands in estimated minimum connection flow, ranging from 9,430 cfs at Old Charlie Wash to $17,400 \mathrm{cfs}$ at Bonanza Bridge. There was much less variation in 2005 (11,166 to 13,000 cfs).

Changes in connection flows differed between upstream and downstream breaches with upstream breaches showing a much larger increase since 2005 compared to downstream breaches (Table 5). The mean connection flow of upstream breaches in 2012 was 17,267 cfs $(15,300$ to $20,100 \mathrm{cfs})$ compared to $12,389 \mathrm{cfs}(11,166$ to $13,000 \mathrm{cfs})$ in 2005 , and represents an increase of $4,878 \mathrm{cfs}(3,400$ to $7,100 \mathrm{cfs})$ for upstream breaches. The mean connection flow of downstream breaches in 2012 was $13,503 \mathrm{cfs}(9,430$ to $17,400 \mathrm{cfs})$ compared to the 2005 mean of $13,056 \mathrm{cfs}$ $(12,433$ to $13,900 \mathrm{cfs})$, and represents an increase of $465 \mathrm{cfs}(-3,570$ to $3,900 \mathrm{cfs})$ for downstream breaches.

Estimated fish passage flows in 2012 were approximately 2,300 to 2,600 cfs higher than connection flows in the Ouray National Wildlife Refuge wetlands (Johnson Bottom, Leota Bottom, and Old Charlie Wash) and 3,300 to 3,600 cfs higher than connection flows in the wetlands further upstream. In 2012, the mean passage flow for the floodplain wetlands surveyed was $19,900 \mathrm{cfs}(11,600$ to $27,900 \mathrm{cfs}$; Table 6$)$. In 2012, the mean minimum passage flow for the floodplain wetlands surveyed (i.e., the lowest of all levee breaches in each wetland) was approximately $16,343 \mathrm{cfs}(11,600$ to $20,800 \mathrm{cfs})$. 
We reassessed floodplain wetland connection of eight priority wetlands in the Middle Green River in 2012 to determine if high magnitude peak flows since 2005 had resulted in changes in the levee breaches and connection channels of the se wetlands. Knowing the actual connection flows in any given year is critical to defining the target peak flows during the runoff season to meet the biological objectives identified in Muth et al. (2000) and in the Larval Trigger Study Plan (Larval Trigger Study Plan Ad Hoc Committee 2012).

Our results indicate that there is a need for periodic reassessments of levee breaches and connection channels especially following very high peak flows. In 2012, there were considerable differences from connection flows measured or estimated in 2005 at most of the levee breaches and connection channels we surveyed. Differences between 2012 and 2005 floodplain connection flows were related to the amount of scour and sediment deposition in levee breaches and the intervening channels that connect the wetlands to the river's main channel at high flows. In general, the flows needed to connect floodplain wetlands at upstream breaches increased, and connection flows for downstream breaches either increased less or decreased since 2005. In the wetlands studied, upstream breaches were topographically higher than the wetland, while downstream breaches were lower than the wetland. This topographic variation likely explains the deposition patterns we observed. Water flowing into an upstream breach would deposit sediment once it encountered the low velocity water of the wetland, and, as a consequence, upstream breaches and channels would accumulate fine sediment. The wetland and connection channels serve as traps for sediment, and water exiting through the downstream breach would have a lower sediment load and would more likely scour during flow-through or as flows recede after the peak.

The configuration and length of the connection channel of upstream inlets can affect where deposition occurs and would likely affect connection in later years. Water flowing into longer channels (i.e., when the wetland is further from the breach) would retain its sediment load in suspension until the low-velocity water of the wetland was encountered. This was apparent at Bonanza Bridge where large sediment deposits formed near the edge of the wetland boundary in 2008 and 2011 (Figures 13 and B-7). These deposits may not restrict future connection because the channel is sufficiently wide to allow water to flow around the deposit. In contrast, and as another example, BB-IN-3 has a much shorter connection channel, and sediment deposition occurred much closer to the breach (Figures 15 and B-9).

Downstream breaches also serve as inlets for flood water. Water depth in downstream connection channels increase as flows rise until connection with the wetland margin occurs, at which time the wetland begins to fill. Downstream breaches can be depositional areas during this filling process, but when peak flows recede, scour of new deposits would occur as water flows out of the wetland and the wetland water surface stabilizes to a lower elevation.

Our observations support those of Heitmeyer and Fredrickson (2005), who stated that high flows may increase sedimentation and debris build up in upstream breaches, resulting in higher subsequent connection flows in these breaches, but would tend to scour downstream 
breaches, resulting in maintenance or reduction of connection flows. Our results suggest that for upstream breaches to remain as viable connections to floodplain wetlands over the long term, regular breach and connection channel inspection and maintenance may be required.

\section{CONCLUSIONS}

- Substantial changes from 2005 in estimated connection flows at levee breaches of seven priority floodplain wetlands in the middle Green River were observed in 2012, and these changes resulted from significant deposition of sediment in breaches and connection channels during intervening high peak flows.

- Mean connection flow for surveyed wetlands in 2012 was 13,503 cfs compared to $12,694 \mathrm{cfs}$ in 2005 , an increase of $826 \mathrm{cfs}$.

- Most individual breaches showed an increase in the flow needed to connect the wetland to the main channel. The mean change was an increase of 3,815 cfs; only three breaches showed a decrease (ER-OUT, AB-OUT, and OC-OUT-2) with decreases of 1,133 cfs, $3,010 \mathrm{cfs}$, and 3,570 cfs, respectively.

- Sediment deposition was apparent in most upstream breaches but not downstream breaches, and this deposition resulted in an increase in estimated connection flows. In 2012 , mean connection flow of upstream breaches was $17,267 \mathrm{cfs}$ compared to $12,389 \mathrm{cfs}$ in 2005, an increase of 4,878 cfs. In 2012, mean minimum connection flow of downstream breaches was 13,503 cfs compared to $13,056 \mathrm{cfs}$ in 2005, an increase of 465 cfs.

- Estimated fish passage flows (those flows needed to allow passage of subadult and adult fish) were approximately 2,300 to 2,600 cfs higher than connection flows in the Ouray National Wildlife Refuge wetlands (Johnson Bottom, Leota Bottom, and Old Charlie Wash) and 3,300 to 3,600 cfs higher than estimated connection flows in the wetlands further upstream. In 2012, the mean estimated fish passage flow for the floodplain wetlands surveyed was $19,900 \mathrm{cfs}(11,600$ to $27,900 \mathrm{cfs})$. The mean estimated minimum fish passage flow for the floodplain wetlands surveyed (i.e., the lowest of all levee breaches in each wetland) was approximately $16,343 \mathrm{cfs}$ (11,600 to 20,800 cfs). 


\section{RECOMMENDATIONS}

- Resurvey floodplain wetland breaches and their connection channels following peak flows that exceed previously determined connection flows to determine if those peak flows have altered connection flows.

- Determine connection of floodplain wetlands annually by direct observation. Ideally, determinations would be made annually of initial connection flows at upstream and downstream breaches and the degree of filling and draining through the peak flow cycle.

- Measure the surface area of floodplain wetlands after peak flows recede and through the summer and winter to determine if floodplain wetlands provide suitable habitat for razorback suckers between flooding events that reconnect the wetlands to the main channel.

- Consider modification of floodplain wetland breaches and connection channels to provide connection to the main channel river at a return frequency of 1.5 years (probability of about $67 \%$ ) to mimic pre-dam flooding frequency.

- Consider modifications of wetlands to prevent sediment deposition from blocking inflow. These modifications could include (1) actively reconfiguring levee breaches, connection channels, and wetland topography to minimize the blockage of connection channels; (2) filling or allowing the filling of upstream breaches; (3) creating control structures such as those that have been successfully deployed at Stewart Lake, Johnson Bottom, and Old Charlie Wash; and (4) managing vegetation encroachment that exacerbates sediment deposition in breaches and channels.

Bestgen, K.R., G.B. Haines, and A.A. Hill, 2011, Synthesis of Flood Plain Wetland Information: Timing of Razorback Sucker Reproduction in the Green River, Utah, Related to Stream Flow, Water Temperature, and Flood Plain Wetland Availability, final report to the Upper Colorado River Endangered Fish Recovery Program, Denver, Colorado, Larval Fish Laboratory Contribution 163.

Burdick, B.D., 1997, Minimum Flow Recommendation for Passage of Colorado Squawfish and Razorback Sucker in the 2.3-mile Reach of the Lower Gunnison River: Redlands Diversion Dam to the Colorado River Confluence, final report to the Upper Colorado River Endangered Fish Recovery Program, Denver, Colorado. 
Flo Engineering, 1997, Green River Floodplain Habitat Restoration Investigations, Bureau of Land Management Sites and Ouray National Wildlife Refuge Sites Near Vernal, Utah, Final Report. Prepared for the Recovery Program for the Endangered Fishes of the Upper Colorado River. Breckenridge, CO.

Heitmeyer, M.E. and L.H. Fredrickson, 2005, An Evaluation of Ecosystem Restoration and Management Options for the Ouray National Wildlife Refuge, Utah, report prepared for the U.S. Fish and Wildlife Service, Region 6, Denver, Colorado.

LaGory, K.E., J.W. Hayse, and D. Tomasko, 2003, Recommended Priorities for Geomorphology Research in Endangered Fish Habitats of the Upper Colorado River Basin, final report to the U.S. Fish and Wildlife Service Upper Colorado River Endangered Fish Recovery Program, Denver, Colorado.

Larval Trigger Study Plan Ad Hoc Committee, 2012, Study Plan to Examine the Effects of Using Larval Razorback Sucker Occurrence in the Green River as a Trigger for Flaming Gorge Dam Peak Releases, final report prepared for the Upper Colorado River Endangered Fish Recovery Program, Denver, March.

Muth, R.T., L.W. Crist, K.E. LaGory, J.W. Hayse, K.R. Bestgen, T.P. Ryan, J.K. Lyons, and R.A. Valdez, 2000, Flow and Temperature Recommendations for Endangered Fishes in the Green River Downstream of Flaming Gorge Dam, final report to the Upper Colorado River Endangered Fish Recovery Program, Denver, Project No. FG-53.

Reclamation. 2006. Record of Decision, Operation of Flaming Gorge Dam, Final Environmental Impact Statement. Bureau of Reclamation, Upper Colorado Region, Salt Lake City, Utah. February.

Tetra Tech, 2005, Floodplain Habitat Restoration, 2005 Monitoring Final Report, Green River, Utah, prepared for the Upper Colorado River Endangered Fish Recovery Program, Denver, Colorado, GSA Contract Tetra Tech Inc., Project No. 0929-004-00.

Valdez, R.A., and P. Nelson, 2004, Green River Subbasin Floodplain Management Plan, Upper Colorado River Endangered Fish Recovery Program, Project Number C-6, Denver, Colorado. 
1

2

3

4

5

6

13

14

15

16

17

18

19

\section{APPENDIX A:}

USGS STAGE-FLOW TABLES FOR THE JENSEN AND OURAY GAGES 
1

2

3

4

5

6

7

8

9

10

11

12

13

14

15

16

17

18

19

This page intentionally left blank. 


\section{APPENDIX A:}

\section{USGS STAGE-FLOW TABLES FOR THE JENSEN AND OURAY GAGES}

This appendix presents the stage-flow tables for the Jensen gage (USGS 09261000) and Ouray gage (USGS 9272400) developed by the U.S. Geological Survey (USGS) (Tables A-1 and A-2, respectively). These tables were used as the basis for determining the flows that would connect wetlands and allow passage of fish at surveyed levee breaches and connection channels. 
1

2

3

4

5

6

7

8

9

10

11

12

13

14

This page intentionally left blank. 
TABLE A-1 USGS Stage-Flow Table for the Jensen Gage (USGS 09261000) in 2005 and 2012

\begin{tabular}{|c|c|c|c|c|c|c|c|c|}
\hline & & & & \\
\hline & 2005 & 2012 & & 2005 & 2012 & & 2005 & 2012 \\
\hline $\begin{array}{c}\text { Stage } \\
(\mathrm{ft})\end{array}$ & $\begin{array}{c}\text { Flow } \\
(\mathrm{cfs})\end{array}$ & $\begin{array}{l}\text { Flow } \\
\text { (cfs) }\end{array}$ & $\begin{array}{c}\text { Stage } \\
(\mathrm{ft})\end{array}$ & $\begin{array}{l}\text { Flow } \\
\text { (cfs) }\end{array}$ & $\begin{array}{l}\text { Flow } \\
\text { (cfs) }\end{array}$ & $\begin{array}{c}\text { Stage } \\
(\mathrm{ft})\end{array}$ & $\begin{array}{l}\text { Flow } \\
\text { (cfs) }\end{array}$ & $\begin{array}{l}\text { Flow } \\
\text { (cfs) }\end{array}$ \\
\hline 1.87 & 795 & 1,080 & 2.35 & 1,210 & 1,620 & 2.83 & 1,720 & 2,260 \\
\hline 1.88 & 803 & 1,090 & 2.36 & 1,220 & 1,630 & 2.84 & 1,730 & 2,270 \\
\hline 1.89 & 811 & 1,100 & 2.37 & 1,230 & 1,640 & 2.85 & 1,740 & 2,290 \\
\hline 1.90 & 818 & 1,110 & 2.38 & 1,240 & 1,650 & 2.86 & 1,750 & 2,300 \\
\hline 1.91 & 826 & 1,120 & 2.39 & 1,250 & 1,670 & 2.87 & 1,760 & 2,320 \\
\hline 1.92 & 834 & 1,130 & 2.40 & 1,260 & 1,680 & 2.88 & 1,780 & 2,330 \\
\hline 1.93 & 842 & 1,140 & 2.41 & 1,270 & 1,690 & 2.89 & 1,790 & 2,350 \\
\hline 1.94 & 850 & 1,150 & 2.42 & 1,280 & 1,700 & 2.90 & 1,800 & 2,360 \\
\hline 1.95 & 858 & 1,160 & 2.43 & 1,290 & 1,720 & 2.91 & 1,810 & 2,380 \\
\hline 1.96 & 865 & 1,170 & 2.44 & 1,290 & 1,730 & 2.92 & 1,820 & 2,390 \\
\hline 1.97 & 873 & 1,180 & 2.45 & 1,300 & 1,740 & 2.93 & 1,840 & 2,410 \\
\hline 1.98 & 881 & 1,190 & 2.46 & 1,310 & 1,750 & 2.94 & 1,850 & 2,420 \\
\hline 1.99 & 889 & 1,200 & 2.47 & 1,330 & 1,770 & 2.95 & 1,860 & 2,440 \\
\hline 2.00 & 898 & 1,210 & 2.48 & 1,340 & 1,780 & 2.96 & 1,870 & 2,450 \\
\hline 2.01 & 906 & 1,220 & 2.49 & 1,350 & 1,790 & 2.97 & 1,880 & 2,470 \\
\hline 2.02 & 914 & 1,230 & 2.50 & 1,360 & 1,810 & 2.98 & 1,900 & 2,480 \\
\hline 2.03 & 922 & 1,240 & 2.51 & 1,370 & 1,820 & 2.99 & 1,910 & 2,500 \\
\hline 2.04 & 930 & 1,260 & 2.52 & 1,380 & 1,830 & 3.00 & 1,920 & 2,510 \\
\hline 2.05 & 939 & 1,270 & 2.53 & 1,390 & 1,850 & 3.01 & 1,930 & 2,530 \\
\hline 2.06 & 947 & 1,280 & 2.54 & 1,400 & 1,860 & 3.02 & 1,950 & 2,540 \\
\hline 2.07 & 955 & 1,290 & 2.55 & 1,410 & 1,870 & 3.03 & 1,960 & 2,560 \\
\hline 2.08 & 964 & 1,300 & 2.56 & 1,420 & 1,890 & 3.04 & 1,970 & 2,570 \\
\hline 2.09 & 972 & 1,310 & 2.57 & 1,430 & 1,900 & 3.05 & 1,980 & 2,590 \\
\hline 2.10 & 981 & 1,320 & 2.58 & 1,440 & 1,910 & 3.06 & 2,000 & 2,600 \\
\hline 2.11 & 989 & 1,330 & 2.59 & 1,450 & 1,930 & 3.07 & 2,010 & 2,620 \\
\hline 2.12 & 998 & 1,340 & 2.60 & 1,460 & 1,940 & 3.08 & 2,020 & 2,630 \\
\hline 2.13 & 1,010 & 1,360 & 2.61 & 1,470 & 1,950 & 3.09 & 2,030 & 2,650 \\
\hline 2.14 & 1,020 & 1,370 & 2.62 & 1,480 & 1,970 & 3.10 & 2,050 & 2,670 \\
\hline 2.15 & 1,020 & 1,380 & 2.63 & 1,490 & 1,980 & 3.11 & 2,060 & 2,680 \\
\hline 2.16 & 1,030 & 1,390 & 2.64 & 1,500 & 1,990 & 3.12 & 2,070 & 2,700 \\
\hline 2.17 & 1,040 & 1,400 & 2.65 & 1,510 & 2,010 & 3.13 & 2,090 & 2,710 \\
\hline 2.18 & 1,050 & 1,410 & 2.66 & 1,520 & 2,020 & 3.14 & 2,100 & 2,730 \\
\hline 2.19 & 1,060 & 1,420 & 2.67 & 1,540 & 2,030 & 3.15 & 2,110 & 2,740 \\
\hline 2.20 & 1,070 & 1,440 & 2.68 & 1,550 & 2,050 & 3.16 & 2,130 & 2,760 \\
\hline 2.21 & 1,080 & 1,450 & 2.69 & 1,560 & 2,060 & 3.17 & 2,140 & 2,780 \\
\hline 2.22 & 1,090 & 1,460 & 2.70 & 1,570 & 2,080 & 3.18 & 2,150 & 2,790 \\
\hline 2.23 & 1,100 & 1,470 & 2.71 & 1,580 & 2,090 & 3.19 & 2,160 & 2,810 \\
\hline 2.24 & 1,100 & 1,480 & 2.72 & 1,590 & 2,100 & 3.20 & 2,180 & 2,820 \\
\hline 2.25 & 1,110 & 1,500 & 2.73 & 1,600 & 2,120 & 3.21 & 2,190 & 2,840 \\
\hline 2.26 & 1,120 & 1,510 & 2.74 & 1,610 & 2,130 & 3.22 & 2,200 & 2,860 \\
\hline 2.27 & 1,130 & 1,520 & 2.75 & 1,620 & 2,150 & 3.23 & 2,220 & 2,870 \\
\hline 2.28 & 1,140 & 1,530 & 2.76 & 1,640 & 2,160 & 3.24 & 2,230 & 2,890 \\
\hline 2.29 & 1,150 & 1,540 & 2.77 & 1,650 & 2,170 & 3.25 & 2,250 & 2,900 \\
\hline 2.30 & 1,160 & 1,560 & 2.78 & 1,660 & 2,190 & 3.26 & 2,260 & 2,920 \\
\hline 2.31 & 1,170 & 1,570 & 2.79 & 1,670 & 2,200 & 3.27 & 2,270 & 2,940 \\
\hline 2.32 & 1,180 & 1,580 & 2.80 & 1,680 & 2,220 & 3.28 & 2,290 & 2,950 \\
\hline 2.33 & 1,190 & 1,590 & 2.81 & 1,690 & 2,230 & 3.29 & 2,300 & 2,970 \\
\hline 2.34 & 1,200 & 1,600 & 2.82 & 1,700 & 2,240 & 3.30 & 2,310 & 2,990 \\
\hline
\end{tabular}




\begin{tabular}{|c|c|c|c|c|c|c|c|c|}
\hline $\begin{array}{l}\text { Stage } \\
(\mathrm{ft})\end{array}$ & $\begin{array}{l}2005 \\
\text { Flow } \\
(\mathrm{cfs})\end{array}$ & $\begin{array}{l}2012 \\
\text { Flow } \\
(\mathrm{cfs})\end{array}$ & $\begin{array}{l}\text { Stage } \\
(\mathrm{ft})\end{array}$ & $\begin{array}{l}2005 \\
\text { Flow } \\
(\mathrm{cfs})\end{array}$ & $\begin{array}{l}2012 \\
\text { Flow } \\
(\mathrm{cfs})\end{array}$ & $\begin{array}{c}\text { Stage } \\
(\mathrm{ft})\end{array}$ & $\begin{array}{l}2005 \\
\text { Flow } \\
(\mathrm{cfs})\end{array}$ & $\begin{array}{l}2012 \\
\text { Flow } \\
(\mathrm{cfs})\end{array}$ \\
\hline 3.31 & 2,330 & 3,000 & 3.81 & 3,080 & 3,860 & 4.31 & 3,940 & 4,790 \\
\hline 3.32 & 2,340 & 3,020 & 3.82 & 3,090 & 3,880 & 4.32 & 3,960 & 4,810 \\
\hline 3.33 & 2,350 & 3,040 & 3.83 & 3,110 & 3,900 & 4.33 & 3,980 & 4,830 \\
\hline 3.34 & 2,370 & 3,050 & 3.84 & 3,120 & 3,920 & 4.34 & 4,000 & 4,850 \\
\hline 3.35 & 2,380 & 3,070 & 3.85 & 3,140 & 3,920 & 4.35 & 4,020 & 4,870 \\
\hline 3.36 & 2,400 & 3,090 & 3.86 & 3,160 & 3,940 & 4.36 & 4,030 & 4,890 \\
\hline 3.37 & 2,410 & 3,100 & 3.87 & 3,170 & 3,960 & 4.37 & 4,050 & 4,910 \\
\hline 3.38 & 2,420 & 3,120 & 3.88 & 3,190 & 3,980 & 4.38 & 4,070 & 4,930 \\
\hline 3.39 & 2,440 & 3,140 & 3.89 & 3,210 & 4,000 & 4.39 & 4,090 & 4,950 \\
\hline 3.40 & 2,450 & 3,150 & 3.90 & 3,220 & 4,010 & 4.40 & 4,110 & 4,970 \\
\hline 3.41 & 2,470 & 3,170 & 3.91 & 3,240 & 4,030 & 4.41 & 4,130 & 4,990 \\
\hline 3.42 & 2,480 & 3,190 & 3.92 & 3,260 & 4,050 & 4.42 & 4,150 & 5,010 \\
\hline 3.43 & 2,500 & 3,200 & 3.93 & 3,270 & 4,070 & 4.43 & 4,170 & 5,040 \\
\hline 3.44 & 2,510 & 3,220 & 3.94 & 3,290 & 4,090 & 4.44 & 4,190 & 5,060 \\
\hline 3.45 & 2,520 & 3,240 & 3.95 & 3,310 & 4,110 & 4.45 & 4,210 & 5,080 \\
\hline 3.46 & 2,540 & 3,260 & 3.96 & 3,320 & 4,130 & 4.46 & 4,230 & 5,100 \\
\hline 3.47 & 2,550 & 3,270 & 3.97 & 3,340 & 4,150 & 4.47 & 4,240 & 5,120 \\
\hline 3.48 & 2,570 & 3,290 & 3.98 & 3,360 & 4,170 & 4.48 & 4,260 & 5,140 \\
\hline 3.49 & 2,580 & 3,310 & 3.99 & 3,370 & 4,190 & 4.49 & 4,280 & 5,160 \\
\hline 3.50 & 2,600 & 3,320 & 4.00 & 3,390 & 4,210 & 4.50 & 4,300 & 5,180 \\
\hline 3.51 & 2,610 & 3,340 & 4.01 & 3,410 & 4,230 & 4.51 & 4,320 & 5,210 \\
\hline 3.52 & 2,630 & 3,360 & 4.02 & 3,420 & 4,240 & 4.52 & 4,340 & 5,230 \\
\hline 3.53 & 2,640 & 3,380 & 4.03 & 3,440 & 4,260 & 4.53 & 4,360 & 5,250 \\
\hline 3.54 & 2,660 & 3,390 & 4.04 & 3,460 & 4,280 & 4.54 & 4,380 & 5,250 \\
\hline 3.55 & 2,670 & 3,410 & 4.05 & 3,480 & 4,300 & 4.55 & 4,400 & 5,270 \\
\hline 3.56 & 2,690 & 3,430 & 4.06 & 3,490 & 4,320 & 4.56 & 4,420 & 5,290 \\
\hline 3.57 & 2,700 & 3,450 & 4.07 & 3,510 & 4,340 & 4.57 & 4,440 & 5,310 \\
\hline 3.58 & 2,720 & 3,460 & 4.08 & 3,530 & 4,340 & 4.58 & 4,460 & 5,330 \\
\hline 3.59 & 2,730 & 3,480 & 4.09 & 3,550 & 4,360 & 4.59 & 4,480 & 5,360 \\
\hline 3.60 & 2,750 & 3,500 & 4.10 & 3,560 & 4,380 & 4.60 & 4,500 & 5,380 \\
\hline 3.61 & 2,760 & 3,520 & 4.11 & 3,580 & 4,400 & 4.61 & 4,520 & 5,400 \\
\hline 3.62 & 2,780 & 3,520 & 4.12 & 3,600 & 4,420 & 4.62 & 4,540 & 5,420 \\
\hline 3.63 & 2,790 & 3,540 & 4.13 & 3,620 & 4,440 & 4.63 & 4,560 & 5,440 \\
\hline 3.64 & 2,810 & 3,550 & 4.14 & 3,630 & 4,460 & 4.64 & 4,580 & 5,470 \\
\hline 3.65 & 2,820 & 3,570 & 4.15 & 3,650 & 4,480 & 4.65 & 4,600 & 5,490 \\
\hline 3.66 & 2,840 & 3,590 & 4.16 & 3,670 & 4,500 & 4.66 & 4,620 & 5,510 \\
\hline 3.67 & 2,850 & 3,610 & 4.17 & 3,690 & 4,520 & 4.67 & 4,640 & 5,530 \\
\hline 3.68 & 2,870 & 3,630 & 4.18 & 3,700 & 4,540 & 4.68 & 4,660 & 5,550 \\
\hline 3.69 & 2,890 & 3,640 & 4.19 & 3,720 & 4,560 & 4.69 & 4,680 & 5,580 \\
\hline 3.70 & 2,900 & 3,660 & 4.20 & 3,740 & 4,580 & 4.70 & 4,700 & 5,600 \\
\hline 3.71 & 2,920 & 3,680 & 4.21 & 3,760 & 4,600 & 4.71 & 4,720 & 5,620 \\
\hline 3.72 & 2,930 & 3,700 & 4.22 & 3,780 & 4,620 & 4.72 & 4,740 & 5,640 \\
\hline 3.73 & 2,950 & 3,720 & 4.23 & 3,790 & 4,640 & 4.73 & 4,760 & 5,660 \\
\hline 3.74 & 2,960 & 3,730 & 4.24 & 3,810 & 4,660 & 4.74 & 4,780 & 5,690 \\
\hline 3.75 & 2,980 & 3,750 & 4.25 & 3,830 & 4,680 & 4.75 & 4,810 & 5,710 \\
\hline 3.76 & 3,000 & 3,770 & 4.26 & 3,850 & 4,700 & 4.76 & 4,830 & 5,730 \\
\hline 3.77 & 3,010 & 3,790 & 4.27 & 3,870 & 4,720 & 4.77 & 4,850 & 5,730 \\
\hline 3.78 & 3,030 & 3,810 & 4.28 & 3,890 & 4,740 & 4.78 & 4,870 & 5,750 \\
\hline 3.79 & 3,040 & 3,830 & 4.29 & 3,900 & 4,760 & 4.79 & 4,890 & 5,780 \\
\hline 3.80 & 3,060 & 3,850 & 4.30 & 3,920 & 4,790 & 4.80 & 4,920 & 5,800 \\
\hline
\end{tabular}




\begin{tabular}{|c|c|c|c|c|c|c|c|c|}
\hline $\begin{array}{l}\text { Stage } \\
(\mathrm{ft})\end{array}$ & $\begin{array}{l}2005 \\
\text { Flow } \\
(\mathrm{cfs})\end{array}$ & $\begin{array}{l}2012 \\
\text { Flow } \\
(\mathrm{cfs})\end{array}$ & $\begin{array}{l}\text { Stage } \\
(\mathrm{ft})\end{array}$ & $\begin{array}{l}2005 \\
\text { Flow } \\
(\mathrm{cfs})\end{array}$ & $\begin{array}{l}2012 \\
\text { Flow } \\
(\mathrm{cfs})\end{array}$ & $\begin{array}{c}\text { Stage } \\
(\mathrm{ft})\end{array}$ & $\begin{array}{l}2005 \\
\text { Flow } \\
(\mathrm{cfs})\end{array}$ & $\begin{array}{l}2012 \\
\text { Flow } \\
(\mathrm{cfs})\end{array}$ \\
\hline 4.81 & 4,940 & 5,820 & 5.31 & 6,110 & 6,950 & 5.81 & 7,410 & 8,180 \\
\hline 4.82 & 4,960 & 5,840 & 5.32 & 6,130 & 6,980 & 5.82 & 7,440 & 8,210 \\
\hline 4.83 & 4,980 & 5,870 & 5.33 & 6,160 & 7,000 & 5.83 & 7,470 & 8,230 \\
\hline 4.84 & 5,000 & 5,890 & 5.34 & 6,180 & 7,030 & 5.84 & 7,490 & 8,260 \\
\hline 4.85 & 5,030 & 5,910 & 5.35 & 6,210 & 7,050 & 5.85 & 7,520 & 8,290 \\
\hline 4.86 & 5,050 & 5,940 & 5.36 & 6,230 & 7,080 & 5.86 & 7,550 & 8,310 \\
\hline 4.87 & 5,070 & 5,960 & 5.37 & 6,260 & 7,100 & 5.87 & 7,580 & 8,340 \\
\hline 4.88 & 5,090 & 5,980 & 5.38 & 6,280 & 7,130 & 5.88 & 7,610 & 8,370 \\
\hline 4.89 & 5,120 & 6,000 & 5.39 & 6,310 & 7,150 & 5.89 & 7,630 & 8,390 \\
\hline 4.9 & 5,140 & 6,030 & 5.40 & 6,330 & 7,180 & 5.90 & 7,660 & 8,420 \\
\hline 4.91 & 5,160 & 6,050 & 5.41 & 6,360 & 7,200 & 5.91 & 7,690 & 8,450 \\
\hline 4.92 & 5,180 & 6,070 & 5.42 & 6,380 & 7,230 & 5.92 & 7,720 & 8,470 \\
\hline 4.93 & 5,210 & 6,100 & 5.43 & 6,410 & 7,250 & 5.93 & 7,750 & 8,470 \\
\hline 4.94 & 5,230 & 6,120 & 5.44 & 6,430 & 7,280 & 5.94 & 7,770 & 8,500 \\
\hline 4.95 & 5,250 & 6,140 & 5.45 & 6,460 & 7,300 & 5.95 & 7,800 & 8,530 \\
\hline 4.96 & 5,280 & 6,170 & 5.46 & 6,490 & 7,330 & 5.96 & 7,830 & 8,550 \\
\hline 4.97 & 5,300 & 6,190 & 5.47 & 6,510 & 7,330 & 5.97 & 7,860 & 8,580 \\
\hline 4.98 & 5,320 & 6,210 & 5.48 & 6,540 & 7,350 & 5.98 & 7,890 & 8,610 \\
\hline 4.99 & 5,340 & 6,230 & 5.49 & 6,560 & 7,380 & 5.99 & 7,920 & 8,640 \\
\hline 5.00 & 5,370 & 6,230 & 5.50 & 6,590 & 7,400 & 6.00 & 7,940 & 8,660 \\
\hline 5.01 & 5,390 & 6,260 & 5.51 & 6,610 & 7,430 & 6.01 & 7,970 & 8,690 \\
\hline 5.02 & 5,410 & 6,280 & 5.52 & 6,640 & 7,450 & 6.02 & 8,000 & 8,720 \\
\hline 5.03 & 5,440 & 6,300 & 5.53 & 6,670 & 7,480 & 6.03 & 8,030 & 8,740 \\
\hline 5.04 & 5,460 & 6,330 & 5.54 & 6,690 & 7,500 & 6.04 & 8,060 & 8,770 \\
\hline 5.05 & 5,480 & 6,350 & 5.55 & 6,720 & 7,530 & 6.05 & 8,090 & 8,800 \\
\hline 5.06 & 5,510 & 6,380 & 5.56 & 6,740 & 7,550 & 6.06 & 8,120 & 8,830 \\
\hline 5.07 & 5,530 & 6,400 & 5.57 & 6,770 & 7,580 & 6.07 & 8,140 & 8,850 \\
\hline 5.08 & 5,550 & 6,420 & 5.58 & 6,800 & 7,610 & 6.08 & 8,170 & 8,880 \\
\hline 5.09 & 5,580 & 6,450 & 5.59 & 6,820 & 7,630 & 6.09 & 8,200 & 8,910 \\
\hline 5.10 & 5,600 & 6,470 & 5.60 & 6,850 & 7,660 & 6.10 & 8,230 & 8,940 \\
\hline 5.11 & 5,620 & 6,490 & 5.61 & 6,870 & 7,680 & 6.11 & 8,260 & 8,970 \\
\hline 5.12 & 5,650 & 6,520 & 5.62 & 6,900 & 7,710 & 6.12 & 8,290 & 8,990 \\
\hline 5.13 & 5,670 & 6,540 & 5.63 & 6,930 & 7,730 & 6.13 & 8,320 & 9,020 \\
\hline 5.14 & 5,700 & 6,570 & 5.64 & 6,950 & 7,760 & 6.14 & 8,350 & 9,050 \\
\hline 5.15 & 5,720 & 6,590 & 5.65 & 6,980 & 7,790 & 6.15 & 8,380 & 9,080 \\
\hline 5.16 & 5,740 & 6,610 & 5.66 & 7,010 & 7,810 & 6.16 & 8,410 & 9,080 \\
\hline 5.17 & 5,770 & 6,640 & 5.67 & 7,030 & 7,840 & 6.17 & 8,440 & 9,100 \\
\hline 5.18 & 5,790 & 6,660 & 5.68 & 7,060 & 7,860 & 6.18 & 8,460 & 9,130 \\
\hline 5.19 & 5,820 & 6,690 & 5.69 & 7,090 & 7,890 & 6.19 & 8,490 & 9,160 \\
\hline 5.20 & 5,840 & 6,710 & 5.70 & 7,110 & 7,890 & 6.20 & 8,520 & 9,190 \\
\hline 5.21 & 5,860 & 6,730 & 5.71 & 7,140 & 7,920 & 6.21 & 8,550 & 9,220 \\
\hline 5.22 & 5,890 & 6,760 & 5.72 & 7,170 & 7,940 & 6.22 & 8,580 & 9,240 \\
\hline 5.23 & 5,910 & 6,780 & 5.73 & 7,190 & 7,970 & 6.23 & 8,610 & 9,270 \\
\hline 5.24 & 5,940 & 6,780 & 5.74 & 7,220 & 7,990 & 6.24 & 8,640 & 9,300 \\
\hline 5.25 & 5,960 & 6,810 & 5.75 & 7,250 & 8,020 & 6.25 & 8,670 & 9,330 \\
\hline 5.26 & 5,990 & 6,830 & 5.76 & 7,280 & 8,050 & 6.26 & 8,700 & 9,360 \\
\hline 5.27 & 6,010 & 6,860 & 5.77 & 7,300 & 8,070 & 6.27 & 8,730 & 9,380 \\
\hline 5.28 & 6,030 & 6,880 & 5.78 & 7,330 & 8,100 & 6.28 & 8,760 & 9,410 \\
\hline 5.29 & 6,060 & 6,900 & 5.79 & 7,360 & 8,130 & 6.29 & 8,790 & 9,440 \\
\hline 5.30 & 6,080 & 6,930 & 5.80 & 7,380 & 8,150 & 6.30 & 8,820 & 9,470 \\
\hline
\end{tabular}




\begin{tabular}{|c|c|c|c|c|c|c|c|c|}
\hline & & & & \\
\hline & 2005 & 2012 & & 2005 & 2012 & & 2005 & 2012 \\
\hline $\begin{array}{l}\text { Stage } \\
(\mathrm{ft})\end{array}$ & $\begin{array}{l}\text { Flow } \\
\text { (cfs) }\end{array}$ & $\begin{array}{l}\text { Flow } \\
\text { (cfs) }\end{array}$ & $\begin{array}{c}\text { Stage } \\
(\mathrm{ft})\end{array}$ & $\begin{array}{l}\text { Flow } \\
\text { (cfs) }\end{array}$ & $\begin{array}{l}\text { Flow } \\
\text { (cfs) }\end{array}$ & $\begin{array}{l}\text { Stage } \\
(\mathrm{ft})\end{array}$ & $\begin{array}{l}\text { Flow } \\
\text { (cfs) }\end{array}$ & $\begin{array}{l}\text { Flow } \\
\text { (cfs) }\end{array}$ \\
\hline 6.31 & 8,850 & 9,500 & 6.81 & 10,200 & 10,900 & 7.31 & 11,700 & 12,400 \\
\hline 6.32 & 8,880 & 9,530 & 6.82 & 10,300 & 11,000 & 7.32 & 11,700 & 12,500 \\
\hline 6.33 & 8,910 & 9,560 & 6.83 & 10,300 & 11,000 & 7.33 & 11,700 & 12,500 \\
\hline 6.34 & 8,940 & 9,580 & 6.84 & 10,300 & 11,000 & 7.34 & 11,700 & 12,500 \\
\hline 6.35 & 8,970 & 9,610 & 6.85 & 10,300 & 11,100 & 7.35 & 11,800 & 12,600 \\
\hline 6.36 & 9,000 & 9,640 & 6.86 & 10,400 & 11,100 & 7.36 & 11,800 & 12,600 \\
\hline 6.37 & 9,030 & 9,670 & 6.87 & 10,400 & 11,100 & 7.37 & 11,800 & 12,600 \\
\hline 6.38 & 9,060 & 9,700 & 6.88 & 10,400 & 11,100 & 7.38 & 11,900 & 12,600 \\
\hline 6.39 & 9,090 & 9,700 & 6.89 & 10,500 & 11,200 & 7.39 & 11,900 & 12,700 \\
\hline 6.40 & 9,120 & 9,730 & 6.90 & 10,500 & 11,200 & 7.40 & 11,900 & 12,700 \\
\hline 6.41 & 9,140 & 9,760 & 6.91 & 10,500 & 11,200 & 7.41 & 12,000 & 12,700 \\
\hline 6.42 & 9,170 & 9,780 & 6.92 & 10,500 & 11,300 & 7.42 & 12,000 & 12,800 \\
\hline 6.43 & 9,200 & 9,810 & 6.93 & 10,600 & 11,300 & 7.43 & 12,000 & 12,800 \\
\hline 6.44 & 9,220 & 9,840 & 6.94 & 10,600 & 11,300 & 7.44 & 12,000 & 12,800 \\
\hline 6.45 & 9,250 & 9,870 & 6.95 & 10,600 & 11,400 & 7.45 & 12,100 & 12,900 \\
\hline 6.46 & 9,280 & 9,900 & 6.96 & 10,600 & 11,400 & 7.46 & 12,100 & 12,900 \\
\hline 6.47 & 9,300 & 9,930 & 6.97 & 10,700 & 11,400 & 7.47 & 12,100 & 12,900 \\
\hline 6.48 & 9,330 & 9,960 & 6.98 & 10,700 & 11,400 & 7.48 & 12,200 & 12,900 \\
\hline 6.49 & 9,360 & 9,990 & 6.99 & 10,700 & 11,500 & 7.49 & 12,200 & 13,000 \\
\hline 6.50 & 9,380 & 10,000 & 7.00 & 10,800 & 11,500 & 7.50 & 12,200 & 13,000 \\
\hline 6.51 & 9,410 & 10,000 & 7.01 & 10,800 & 11,500 & 7.51 & 12,300 & 13,000 \\
\hline 6.52 & 9,440 & 10,100 & 7.02 & 10,800 & 11,600 & 7.52 & 12,300 & 13,100 \\
\hline 6.53 & 9,460 & 10,100 & 7.03 & 10,800 & 11,600 & 7.53 & 12,300 & 13,100 \\
\hline 6.54 & 9,490 & 10,100 & 7.04 & 10,900 & 11,600 & 7.54 & 12,300 & 13,100 \\
\hline 6.55 & 9,520 & 10,200 & 7.05 & 10,900 & 11,700 & 7.55 & 12,400 & 13,100 \\
\hline 6.56 & 9,540 & 10,200 & 7.06 & 10,900 & 11,700 & 7.56 & 12,400 & 13,200 \\
\hline 6.57 & 9,570 & 10,200 & 7.07 & 11,000 & 11,700 & 7.57 & 12,400 & 13,200 \\
\hline 6.58 & 9,600 & 10,300 & 7.08 & 11,000 & 11,700 & 7.58 & 12,500 & 13,200 \\
\hline 6.59 & 9,620 & 10,300 & 7.09 & 11,000 & 11,800 & 7.59 & 12,500 & 13,300 \\
\hline 6.60 & 9,650 & 10,300 & 7.1 & 11,000 & 11,800 & 7.60 & 12,500 & 13,300 \\
\hline 6.61 & 9,680 & 10,300 & 7.11 & 11,100 & 11,800 & 7.61 & 12,600 & 13,300 \\
\hline 6.62 & 9,710 & 10,400 & 7.12 & 11,100 & 11,900 & 7.62 & 12,600 & 13,300 \\
\hline 6.63 & 9,730 & 10,400 & 7.13 & 11,100 & 11,900 & 7.63 & 12,600 & 13,400 \\
\hline 6.64 & 9,760 & 10,400 & 7.14 & 11,200 & 11,900 & 7.64 & 12,700 & 13,400 \\
\hline 6.65 & 9,790 & 10,500 & 7.15 & 11,200 & 12,000 & 7.65 & 12,700 & 13,400 \\
\hline 6.66 & 9,810 & 10,500 & 7.16 & 11,200 & 12,000 & 7.66 & 12,700 & 13,500 \\
\hline 6.67 & 9,840 & 10,500 & 7.17 & 11,200 & 12,000 & 7.67 & 12,700 & 13,500 \\
\hline 6.68 & 9,870 & 10,500 & 7.18 & 11,300 & 12,000 & 7.68 & 12,800 & 13,500 \\
\hline 6.69 & 9,900 & 10,600 & 7.19 & 11,300 & 12,100 & 7.69 & 12,800 & 13,500 \\
\hline 6.70 & 9,920 & 10,600 & 7.20 & 11,300 & 12,100 & 7.70 & 12,800 & 13,600 \\
\hline 6.71 & 9,950 & 10,600 & 7.21 & 11,400 & 12,100 & 7.71 & 12,900 & 13,600 \\
\hline 6.72 & 9,980 & 10,700 & 7.22 & 11,400 & 12,200 & 7.72 & 12,900 & 13,600 \\
\hline 6.73 & 10,000 & 10,700 & 7.23 & 11,400 & 12,200 & 7.73 & 12,900 & 13,700 \\
\hline 6.74 & 10,000 & 10,700 & 7.24 & 11,500 & 12,200 & 7.74 & 13,000 & 13,700 \\
\hline 6.75 & 10,100 & 10,800 & 7.25 & 11,500 & 12,300 & 7.75 & 13,000 & 13,700 \\
\hline 6.76 & 10,100 & 10,800 & 7.26 & 11,500 & 12,300 & 7.76 & 13,000 & 13,800 \\
\hline 6.77 & 10,100 & 10,800 & 7.27 & 11,500 & 12,300 & 7.77 & 13,100 & 13,800 \\
\hline 6.78 & 10,100 & 10,800 & 7.28 & 11,600 & 12,300 & 7.78 & 13,100 & 13,800 \\
\hline 6.79 & 10,200 & 10,900 & 7.29 & 11,600 & 12,400 & 7.79 & 13,100 & 13,800 \\
\hline 6.80 & 10,200 & 10,900 & 7.30 & 11,600 & 12,400 & 7.80 & 13,100 & 13,900 \\
\hline
\end{tabular}




\begin{tabular}{|c|c|c|c|c|c|c|c|c|}
\hline & & & & \\
\hline & 2005 & 2012 & & 2005 & 2012 & & 2005 & 2012 \\
\hline $\begin{array}{l}\text { Stage } \\
(\mathrm{ft})\end{array}$ & $\begin{array}{l}\text { Flow } \\
\text { (cfs) }\end{array}$ & $\begin{array}{l}\text { Flow } \\
\text { (cfs) }\end{array}$ & $\begin{array}{c}\text { Stage } \\
(\mathrm{ft})\end{array}$ & $\begin{array}{l}\text { Flow } \\
\text { (cfs) }\end{array}$ & $\begin{array}{l}\text { Flow } \\
\text { (cfs) }\end{array}$ & $\begin{array}{c}\text { Stage } \\
(\mathrm{ft})\end{array}$ & $\begin{array}{l}\text { Flow } \\
\text { (cfs) }\end{array}$ & $\begin{array}{l}\text { Flow } \\
\text { (cfs) }\end{array}$ \\
\hline 7.81 & 13,200 & 13,900 & 8.31 & 14,800 & 15,400 & 8.81 & 16,500 & 17,000 \\
\hline 7.82 & 13,200 & 13,900 & 8.32 & 14,800 & 15,400 & 8.82 & 16,500 & 17,000 \\
\hline 7.83 & 13,200 & 14,000 & 8.33 & 14,800 & 15,500 & 8.83 & 16,500 & 17,100 \\
\hline 7.84 & 13,300 & 14,000 & 8.34 & 14,900 & 15,500 & 8.84 & 16,600 & 17,100 \\
\hline 7.85 & 13,300 & 14,000 & 8.35 & 14,900 & 15,500 & 8.85 & 16,600 & 17,100 \\
\hline 7.86 & 13,300 & 14,000 & 8.36 & 14,900 & 15,600 & 8.86 & 16,600 & 17,100 \\
\hline 7.87 & 13,400 & 14,100 & 8.37 & 15,000 & 15,600 & 8.87 & 16,700 & 17,200 \\
\hline 7.88 & 13,400 & 14,100 & 8.38 & 15,000 & 15,600 & 8.88 & 16,700 & 17,200 \\
\hline 7.89 & 13,400 & 14,100 & 8.39 & 15,000 & 15,700 & 8.89 & 16,700 & 17,200 \\
\hline 7.90 & 13,500 & 14,200 & 8.40 & 15,100 & 15,700 & 8.90 & 16,800 & 17,300 \\
\hline 7.91 & 13,500 & 14,200 & 8.41 & 15,100 & 15,700 & 8.91 & 16,800 & 17,300 \\
\hline 7.92 & 13,500 & 14,200 & 8.42 & 15,100 & 15,800 & 8.92 & 16,800 & 17,300 \\
\hline 7.93 & 13,600 & 14,300 & 8.43 & 15,200 & 15,800 & 8.93 & 16,900 & 17,400 \\
\hline 7.94 & 13,600 & 14,300 & 8.44 & 15,200 & 15,800 & 8.94 & 16,900 & 17,400 \\
\hline 7.95 & 13,600 & 14,300 & 8.45 & 15,200 & 15,800 & 8.95 & 17,000 & 17,400 \\
\hline 7.96 & 13,600 & 14,300 & 8.46 & 15,300 & 15,900 & 8.96 & 17,000 & 17,500 \\
\hline 7.97 & 13,700 & 14,400 & 8.47 & 15,300 & 15,900 & 8.97 & 17,000 & 17,500 \\
\hline 7.98 & 13,700 & 14,400 & 8.48 & 15,300 & 15,900 & 8.98 & 17,100 & 17,500 \\
\hline 7.99 & 13,700 & 14,400 & 8.49 & 15,400 & 16,000 & 8.99 & 17,100 & 17,600 \\
\hline 8.00 & 13,800 & 14,500 & 8.50 & 15,400 & 16,000 & 9.00 & 17,100 & 17,600 \\
\hline 8.01 & 13,800 & 14,500 & 8.51 & 15,400 & 16,000 & 9.01 & 17,200 & 17,600 \\
\hline 8.02 & 13,800 & 14,500 & 8.52 & 15,500 & 16,100 & 9.02 & 17,200 & 17,700 \\
\hline 8.03 & 13,900 & 14,600 & 8.53 & 15,500 & 16,100 & 9.03 & 17,200 & 17,700 \\
\hline 8.04 & 13,900 & 14,600 & 8.54 & 15,500 & 16,100 & 9.04 & 17,300 & 17,700 \\
\hline 8.05 & 13,900 & 14,600 & 8.55 & 15,600 & 16,200 & 9.05 & 17,300 & 17,800 \\
\hline 8.06 & 14,000 & 14,600 & 8.56 & 15,600 & 16,200 & 9.06 & 17,300 & 17,800 \\
\hline 8.07 & 14,000 & 14,700 & 8.57 & 15,600 & 16,200 & 9.07 & 17,400 & 17,800 \\
\hline 8.08 & 14,000 & 14,700 & 8.58 & 15,700 & 16,300 & 9.08 & 17,400 & 17,900 \\
\hline 8.09 & 14,100 & 14,700 & 8.59 & 15,700 & 16,300 & 9.09 & 17,400 & 17,900 \\
\hline 8.10 & 14,100 & 14,800 & 8.60 & 15,700 & 16,300 & 9.10 & 17,500 & 17,900 \\
\hline 8.11 & 14,100 & 14,800 & 8.61 & 15,800 & 16,300 & 9.11 & 17,500 & 18,000 \\
\hline 8.12 & 14,200 & 14,800 & 8.62 & 15,800 & 16,400 & 9.12 & 17,600 & 18,000 \\
\hline 8.13 & 14,200 & 14,900 & 8.63 & 15,800 & 16,400 & 9.13 & 17,600 & 18,000 \\
\hline 8.14 & 14,200 & 14,900 & 8.64 & 15,900 & 16,400 & 9.14 & 17,600 & 18,100 \\
\hline 8.15 & 14,300 & 14,900 & 8.65 & 15,900 & 16,500 & 9.15 & 17,700 & 18,100 \\
\hline 8.16 & 14,300 & 15,000 & 8.66 & 16,000 & 16,500 & 9.16 & 17,700 & 18,100 \\
\hline 8.17 & 14,300 & 15,000 & 8.67 & 16,000 & 16,500 & 9.17 & 17,700 & 18,200 \\
\hline 8.18 & 14,400 & 15,000 & 8.68 & 16,000 & 16,600 & 9.18 & 17,800 & 18,200 \\
\hline 8.19 & 14,400 & 15,000 & 8.69 & 16,100 & 16,600 & 9.19 & 17,800 & 18,200 \\
\hline 8.20 & 14,400 & 15,100 & 8.70 & 16,100 & 16,600 & 9.20 & 17,800 & 18,300 \\
\hline 8.21 & 14,500 & 15,100 & 8.71 & 16,100 & 16,700 & 9.21 & 17,900 & 18,300 \\
\hline 8.22 & 14,500 & 15,100 & 8.72 & 16,200 & 16,700 & 9.22 & 17,900 & 18,300 \\
\hline 8.23 & 14,500 & 15,200 & 8.73 & 16,200 & 16,700 & 9.23 & 17,900 & 18,400 \\
\hline 8.24 & 14,600 & 15,200 & 8.74 & 16,200 & 16,800 & 9.24 & 18,000 & 18,400 \\
\hline 8.25 & 14,600 & 15,200 & 8.75 & 16,300 & 16,800 & 9.25 & 18,000 & 18,400 \\
\hline 8.26 & 14,600 & 15,300 & 8.76 & 16,300 & 16,800 & 9.26 & 18,100 & 18,500 \\
\hline 8.27 & 14,600 & 15,300 & 8.77 & 16,300 & 16,900 & 9.27 & 18,100 & 18,500 \\
\hline 8.28 & 14,700 & 15,300 & 8.78 & 16,400 & 16,900 & 9.28 & 18,100 & 18,500 \\
\hline 8.29 & 14,700 & 15,400 & 8.79 & 16,400 & 16,900 & 9.29 & 18,200 & 18,600 \\
\hline 8.30 & 14,700 & 15,400 & 8.80 & 16,400 & 17,000 & 9.30 & 18,200 & 18,600 \\
\hline
\end{tabular}




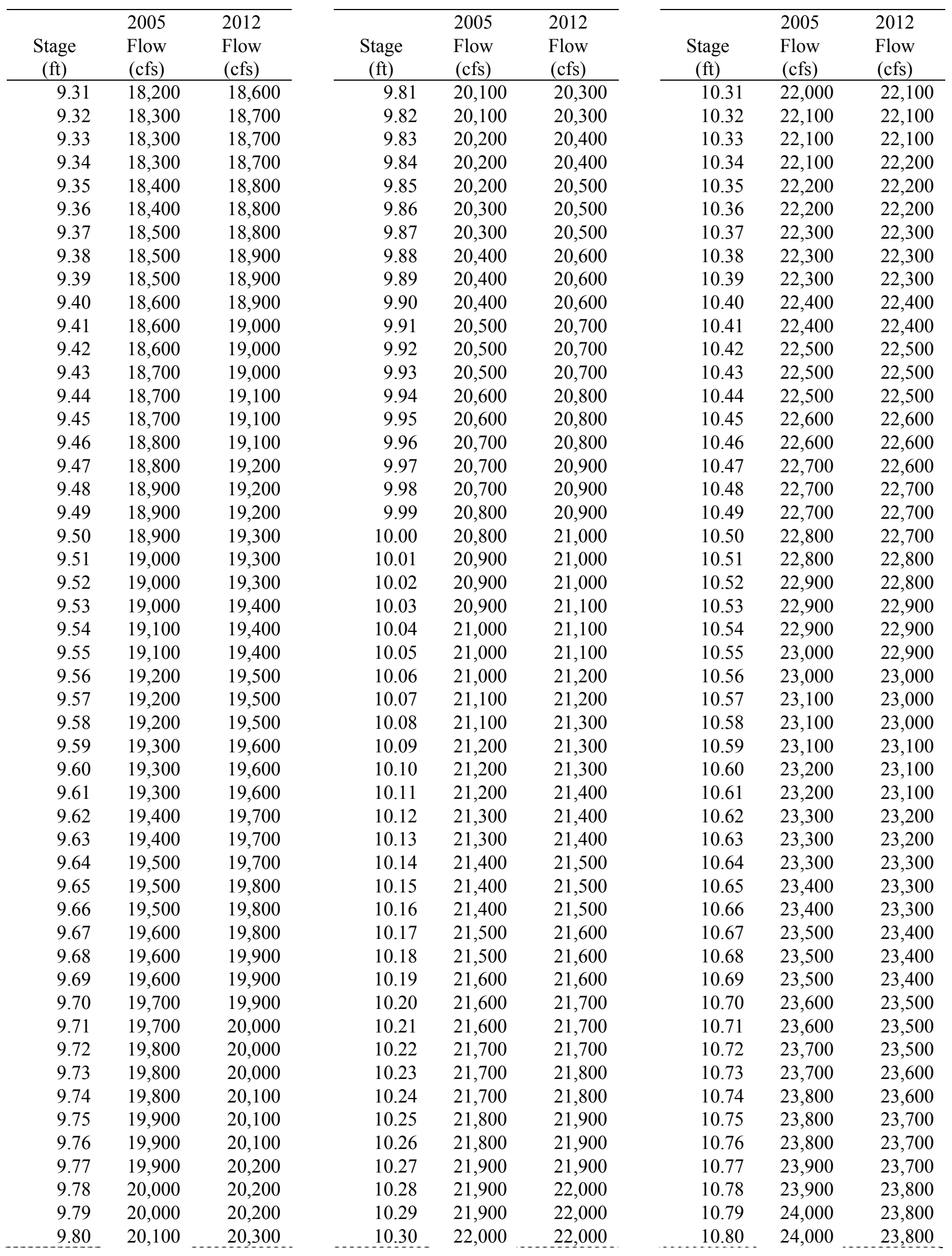




\begin{tabular}{|c|c|c|}
\hline $\begin{array}{c}\text { Stage } \\
(\mathrm{ft})\end{array}$ & $\begin{array}{l}2005 \\
\text { Flow } \\
\text { (cfs) }\end{array}$ & $\begin{array}{l}2012 \\
\text { Flow } \\
\text { (cfs) }\end{array}$ \\
\hline 10.81 & 24,000 & 23,900 \\
\hline 10.82 & 24,100 & 23,900 \\
\hline 10.83 & 24,100 & 23,900 \\
\hline 10.84 & 24,100 & 24,000 \\
\hline 10.85 & 24,200 & 24,000 \\
\hline 10.86 & 24,200 & 24,100 \\
\hline 10.87 & 24,300 & 24,100 \\
\hline 10.88 & 24,300 & 24,100 \\
\hline 10.89 & 24,300 & 24,200 \\
\hline 10.90 & 24,400 & 24,200 \\
\hline 10.91 & 24,400 & 24,200 \\
\hline 10.92 & 24,400 & 24,300 \\
\hline 10.93 & 24,500 & 24,300 \\
\hline 10.94 & 24,500 & 24,400 \\
\hline 10.95 & 24,600 & 24,400 \\
\hline 10.96 & 24,600 & 24,400 \\
\hline 10.97 & 24,600 & 24,500 \\
\hline 10.98 & 24,700 & 24,500 \\
\hline 10.99 & 24,700 & 24,500 \\
\hline 11.00 & 24,700 & 24,600 \\
\hline 11.01 & 24,800 & 24,600 \\
\hline 11.02 & 24,800 & 24,600 \\
\hline 11.03 & 24,900 & 24,700 \\
\hline 11.04 & 24,900 & 24,700 \\
\hline 11.05 & 24,900 & 24,800 \\
\hline 11.06 & 25,000 & 24,800 \\
\hline 11.07 & 25,000 & 24,800 \\
\hline 11.08 & 25,000 & 24,900 \\
\hline 11.09 & 25,100 & 24,900 \\
\hline 11.10 & 25,100 & 24,900 \\
\hline 11.11 & 25,200 & 25,000 \\
\hline 11.12 & 25,200 & 25,000 \\
\hline 11.13 & 25,200 & 25,100 \\
\hline 11.14 & 25,300 & 25,100 \\
\hline 11.15 & 25,300 & 25,100 \\
\hline 11.16 & 25,300 & 25,200 \\
\hline 11.17 & 25,400 & 25,200 \\
\hline 11.18 & 25,400 & 25,200 \\
\hline 11.19 & 25,500 & 25,300 \\
\hline 11.20 & 25,500 & 25,300 \\
\hline 11.21 & 25,500 & 25,400 \\
\hline 11.22 & 25,600 & 25,400 \\
\hline 11.23 & 25,600 & 25,400 \\
\hline 11.24 & 25,700 & 25,500 \\
\hline 11.25 & 25,700 & 25,500 \\
\hline 11.26 & 25,700 & 25,500 \\
\hline 11.27 & 25,800 & 25,600 \\
\hline
\end{tabular}

\begin{tabular}{|c|c|c|}
\hline $\begin{array}{c}\text { Stage } \\
(\mathrm{ft})\end{array}$ & $\begin{array}{l}2005 \\
\text { Flow } \\
\text { (cfs) }\end{array}$ & $\begin{array}{l}2012 \\
\text { Flow } \\
\text { (cfs) }\end{array}$ \\
\hline 11.28 & 25,800 & 25,600 \\
\hline 11.29 & 25,800 & 25,700 \\
\hline 11.30 & 25,900 & 25,700 \\
\hline 11.31 & 25,900 & 25,700 \\
\hline 11.32 & 26,000 & 25,800 \\
\hline 11.33 & 26,000 & 25,800 \\
\hline 11.34 & 26,000 & 25,900 \\
\hline 11.35 & 26,100 & 25,900 \\
\hline 11.36 & 26,100 & 25,900 \\
\hline 11.37 & 26,100 & 26,000 \\
\hline 11.38 & 26,200 & 26,000 \\
\hline 11.39 & 26,200 & 26,000 \\
\hline 11.40 & 26,300 & 26,100 \\
\hline 11.41 & 26,300 & 26,100 \\
\hline 11.42 & 26,300 & 26,200 \\
\hline 11.43 & 26,400 & 26,200 \\
\hline 11.44 & 26,400 & 26,200 \\
\hline 11.45 & 26,500 & 26,300 \\
\hline 11.46 & 26,500 & 26,300 \\
\hline 11.47 & 26,500 & 26,300 \\
\hline 11.48 & 26,600 & 26,400 \\
\hline 11.49 & 26,600 & 26,400 \\
\hline 11.50 & 26,600 & 26,500 \\
\hline 11.51 & 26,700 & 26,500 \\
\hline 11.52 & 26,700 & 26,500 \\
\hline 11.53 & 26,800 & 26,600 \\
\hline 11.54 & 26,800 & 26,600 \\
\hline 11.55 & 26,800 & 26,700 \\
\hline 11.56 & 26,900 & 26,700 \\
\hline 11.57 & 26,900 & 26,700 \\
\hline 11.58 & 27,000 & 26,800 \\
\hline 11.59 & 27,000 & 26,800 \\
\hline 11.60 & 27,000 & 26,800 \\
\hline 11.61 & 27,100 & 26,900 \\
\hline 11.62 & 27,100 & 26,900 \\
\hline 11.63 & 27,200 & 27,000 \\
\hline 11.64 & 27,200 & 27,000 \\
\hline 11.65 & 27,200 & 27,000 \\
\hline 11.66 & 27,300 & 27,100 \\
\hline 11.67 & 27,300 & 27,100 \\
\hline 11.68 & 27,300 & 27,200 \\
\hline 11.69 & 27,400 & 27,200 \\
\hline 11.70 & 27,400 & 27,200 \\
\hline 11.71 & 27,500 & 27,300 \\
\hline 11.72 & 27,500 & 27,300 \\
\hline 11.73 & 27,500 & 27,300 \\
\hline 11.74 & 27,600 & 27,400 \\
\hline
\end{tabular}

\begin{tabular}{|c|c|c|}
\hline $\begin{array}{c}\text { Stage } \\
(\mathrm{ft})\end{array}$ & $\begin{array}{l}2005 \\
\text { Flow } \\
(\mathrm{cfs})\end{array}$ & $\begin{array}{l}2012 \\
\text { Flow } \\
\text { (cfs) }\end{array}$ \\
\hline 11.75 & 27,600 & 27,400 \\
\hline 11.76 & 27,700 & 27,500 \\
\hline 11.77 & 27,700 & 27,500 \\
\hline 11.78 & 27,700 & 27,500 \\
\hline 11.79 & 27,800 & 27,600 \\
\hline 11.80 & 27,800 & 27,600 \\
\hline 11.81 & 27,900 & 27,700 \\
\hline 11.82 & 27,900 & 27,700 \\
\hline 11.83 & 27,900 & 27,700 \\
\hline 11.84 & 28,000 & 27,800 \\
\hline 11.85 & 28,000 & 27,800 \\
\hline 11.86 & 28,100 & 27,900 \\
\hline 11.87 & 28,100 & 27,900 \\
\hline 11.88 & 28,100 & 27,900 \\
\hline 11.89 & 28,200 & 28,000 \\
\hline 11.90 & 28,200 & 28,000 \\
\hline 11.91 & 28,200 & 28,000 \\
\hline 11.92 & 28,300 & 28,100 \\
\hline 11.93 & 28,300 & 28,100 \\
\hline 11.94 & 28,400 & 28,200 \\
\hline 11.95 & 28,400 & 28,200 \\
\hline 11.96 & 28,400 & 28,200 \\
\hline 11.97 & 28,500 & 28,300 \\
\hline 11.98 & 28,500 & 28,300 \\
\hline 11.99 & 28,600 & 28,400 \\
\hline 12.00 & 28,600 & 28,400 \\
\hline 12.01 & 28,600 & 28,400 \\
\hline 12.02 & 28,700 & 28,500 \\
\hline 12.03 & 28,700 & 28,500 \\
\hline 12.04 & 28,800 & 28,600 \\
\hline 12.05 & 28,800 & 28,600 \\
\hline 12.06 & 28,800 & 28,600 \\
\hline 12.07 & 28,900 & 28,700 \\
\hline 12.08 & 28,900 & 28,700 \\
\hline 12.09 & 29,000 & 28,800 \\
\hline 12.10 & 29,000 & 28,800 \\
\hline 12.11 & 29,000 & 28,800 \\
\hline 12.12 & 29,100 & 28,900 \\
\hline 12.13 & 29,100 & 28,900 \\
\hline 12.14 & 29,200 & 29,000 \\
\hline 12.15 & 29,200 & 29,000 \\
\hline 12.16 & 29,200 & 29,000 \\
\hline 12.17 & 29,300 & 29,100 \\
\hline 12.18 & 29,300 & 29,100 \\
\hline 12.19 & 29,400 & 29,200 \\
\hline 12.20 & 29,400 & 29,200 \\
\hline 12.21 & 29,400 & 29,200 \\
\hline
\end{tabular}


TABLE A-2 USGS Stage-Flow Table for the Ouray Gage (USGS 9272400) in 2012

\begin{tabular}{cr} 
Stage & Flow \\
(ft) & (cfs) \\
\hline 14.94 & 930 \\
14.95 & 940 \\
14.96 & 951 \\
14.97 & 961 \\
14.98 & 972 \\
14.99 & 982 \\
15.00 & 992 \\
15.01 & 1,000 \\
15.02 & 1,010 \\
15.03 & 1,020 \\
15.04 & 1,030 \\
15.05 & 1,050 \\
15.06 & 1,060 \\
15.07 & 1,070 \\
15.08 & 1,080 \\
15.09 & 1,090 \\
15.10 & 1,100 \\
15.11 & 1,110 \\
15.12 & 1,120 \\
15.13 & 1,130 \\
15.14 & 1,140 \\
15.15 & 1,150 \\
15.16 & 1,160 \\
15.17 & 1,180 \\
15.18 & 1,190 \\
15.19 & 1,200 \\
15.20 & 1,210 \\
15.21 & 1,220 \\
15.22 & 1,230 \\
15.23 & 1,240 \\
15.24 & 1,250 \\
15.25 & 1,270 \\
15.26 & 1,280 \\
15.27 & 1,290 \\
15.28 & 1,300 \\
15.29 & 1,310 \\
15.30 & 1,320 \\
15.31 & 1,330 \\
15.32 & 1,350 \\
15.33 & 1,360 \\
15.34 & 1,370 \\
15.35 & 1,380 \\
15.36 & 1,390 \\
15.37 & 1,400 \\
15.38 & 1,420 \\
15.39 & 1,430 \\
15.40 & 1,440 \\
15.41 & 1,450 \\
------ \\
&
\end{tabular}

\begin{tabular}{cc} 
Stage & Flow \\
(ft) & (cfs) \\
\hline 15.42 & 1,460 \\
15.43 & 1,470 \\
15.44 & 1,490 \\
15.45 & 1,500 \\
15.46 & 1,510 \\
15.47 & 1,520 \\
15.48 & 1,530 \\
15.49 & 1,550 \\
15.50 & 1,560 \\
15.51 & 1,570 \\
15.52 & 1,580 \\
15.53 & 1,590 \\
15.54 & 1,610 \\
15.55 & 1,620 \\
15.56 & 1,630 \\
15.57 & 1,640 \\
15.58 & 1,660 \\
15.59 & 1,670 \\
15.60 & 1,680 \\
15.61 & 1,690 \\
15.62 & 1,710 \\
15.63 & 1,720 \\
15.64 & 1,730 \\
15.65 & 1,740 \\
15.66 & 1,760 \\
15.67 & 1,770 \\
15.68 & 1,780 \\
15.69 & 1,790 \\
15.70 & 1,810 \\
15.71 & 1,820 \\
15.72 & 1,830 \\
15.73 & 1,840 \\
15.74 & 1,860 \\
15.75 & 1,870 \\
15.76 & 1,880 \\
15.77 & 1,900 \\
15.78 & 1,910 \\
15.79 & 1,920 \\
15.80 & 1,930 \\
15.81 & 1,950 \\
15.82 & 1,960 \\
15.83 & 1,970 \\
15.84 & 1,990 \\
15.85 & 2,000 \\
15.86 & 2,010 \\
15.87 & 2,030 \\
15.88 & 2,040 \\
15.89 & 2,050 \\
...--- \\
& \\
\hline
\end{tabular}

\begin{tabular}{cc} 
Stage & Flow \\
(ft) & (cfs) \\
\hline 15.90 & 2,060 \\
15.91 & 2,080 \\
15.92 & 2,090 \\
15.93 & 2,100 \\
15.94 & 2,120 \\
15.95 & 2,130 \\
15.96 & 2,140 \\
15.97 & 2,160 \\
15.98 & 2,170 \\
15.99 & 2,180 \\
16.00 & 2,200 \\
16.01 & 2,210 \\
16.02 & 2,220 \\
16.03 & 2,240 \\
16.04 & 2,250 \\
16.05 & 2,270 \\
16.06 & 2,280 \\
16.07 & 2,290 \\
16.08 & 2,310 \\
16.09 & 2,320 \\
16.10 & 2,330 \\
16.11 & 2,350 \\
16.12 & 2,360 \\
16.13 & 2,370 \\
16.14 & 2,390 \\
16.15 & 2,400 \\
16.16 & 2,420 \\
16.17 & 2,430 \\
16.18 & 2,440 \\
16.19 & 2,460 \\
16.20 & 2,470 \\
16.21 & 2,490 \\
16.22 & 2,500 \\
16.23 & 2,510 \\
16.24 & 2,530 \\
16.25 & 2,540 \\
16.26 & 2,560 \\
16.27 & 2,570 \\
16.28 & 2,580 \\
16.29 & 2,600 \\
16.30 & 2,610 \\
16.31 & 2,630 \\
16.32 & 2,640 \\
16.33 & 2,660 \\
16.34 & 2,670 \\
16.35 & 2,680 \\
16.36 & 2,700 \\
16.37 & 2,710 \\
\hline... & \\
&
\end{tabular}




\begin{tabular}{cc}
\hline & \\
Stage & Flow \\
(ft) & (cfs) \\
\hline 16.38 & 2,730 \\
16.39 & 2,740 \\
16.40 & 2,760 \\
16.41 & 2,770 \\
16.42 & 2,780 \\
16.43 & 2,800 \\
16.44 & 2,810 \\
16.45 & 2,830 \\
16.46 & 2,840 \\
16.47 & 2,860 \\
16.48 & 2,870 \\
16.49 & 2,890 \\
16.50 & 2,900 \\
16.51 & 2,920 \\
16.52 & 2,930 \\
16.53 & 2,950 \\
16.54 & 2,960 \\
16.55 & 2,970 \\
16.56 & 2,990 \\
16.57 & 3,000 \\
16.58 & 3,020 \\
16.59 & 3,030 \\
16.60 & 3,050 \\
16.61 & 3,060 \\
16.62 & 3,080 \\
16.63 & 3,090 \\
16.64 & 3,110 \\
16.65 & 3,120 \\
16.66 & 3,140 \\
16.67 & 3,150 \\
16.68 & 3,170 \\
16.69 & 3,180 \\
16.70 & 3,200 \\
16.71 & 3,210 \\
16.72 & 3,230 \\
16.73 & 3,240 \\
16.74 & 3,260 \\
16.75 & 3,270 \\
16.76 & 3,290 \\
16.77 & 3,310 \\
16.78 & 3,320 \\
16.79 & 3,340 \\
16.80 & 3,350 \\
16.81 & 3,370 \\
16.82 & 3,380 \\
16.83 & 3,400 \\
16.84 & 3,410 \\
16.85 & 3,430 \\
16.86 & 3,440 \\
16.87 & 3,460 \\
------- \\
1 & \\
\hline
\end{tabular}

\begin{tabular}{cc}
\hline & \\
Stage & Flow \\
(ft) & (cfs) \\
\hline 16.88 & 3,470 \\
16.89 & 3,490 \\
16.90 & 3,510 \\
16.91 & 3,520 \\
16.92 & 3,540 \\
16.93 & 3,550 \\
16.94 & 3,570 \\
16.95 & 3,580 \\
16.96 & 3,600 \\
16.97 & 3,620 \\
16.98 & 3,630 \\
16.99 & 3,650 \\
17.00 & 3,660 \\
17.01 & 3,680 \\
17.02 & 3,690 \\
17.03 & 3,710 \\
17.04 & 3,730 \\
17.05 & 3,740 \\
17.06 & 3,760 \\
17.07 & 3,770 \\
17.08 & 3,790 \\
17.09 & 3,810 \\
17.10 & 3,820 \\
17.11 & 3,840 \\
17.12 & 3,850 \\
17.13 & 3,870 \\
17.14 & 3,890 \\
17.15 & 3,900 \\
17.16 & 3,920 \\
17.17 & 3,930 \\
17.18 & 3,950 \\
17.19 & 3,970 \\
17.20 & 3,980 \\
17.21 & 4,000 \\
17.22 & 4,010 \\
17.23 & 4,030 \\
17.24 & 4,050 \\
17.25 & 4,060 \\
17.26 & 4,080 \\
17.27 & 4,100 \\
17.28 & 4,110 \\
17.29 & 4,130 \\
17.30 & 4,140 \\
17.31 & 4,160 \\
17.32 & 4,180 \\
17.33 & 4,190 \\
17.34 & 4,210 \\
17.35 & 4,230 \\
17.36 & 4,240 \\
17.37 & 4,260 \\
..---- \\
& \\
\hline
\end{tabular}

\begin{tabular}{cc}
\hline Stage & Flow \\
(ft) & (cfs) \\
\hline 17.38 & 4,280 \\
17.39 & 4,290 \\
17.40 & 4,310 \\
17.41 & 4,330 \\
17.42 & 4,340 \\
17.43 & 4,360 \\
17.44 & 4,380 \\
17.45 & 4,390 \\
17.46 & 4,410 \\
17.47 & 4,430 \\
17.48 & 4,440 \\
17.49 & 4,460 \\
17.50 & 4,480 \\
17.51 & 4,490 \\
17.52 & 4,510 \\
17.53 & 4,530 \\
17.54 & 4,540 \\
17.55 & 4,560 \\
17.56 & 4,580 \\
17.57 & 4,590 \\
17.58 & 4,610 \\
17.59 & 4,630 \\
17.60 & 4,640 \\
17.61 & 4,660 \\
17.62 & 4,680 \\
17.63 & 4,700 \\
17.64 & 4,710 \\
17.65 & 4,730 \\
17.66 & 4,750 \\
17.67 & 4,760 \\
17.68 & 4,780 \\
17.69 & 4,800 \\
17.70 & 4,820 \\
17.71 & 4,830 \\
17.72 & 4,850 \\
17.73 & 4,870 \\
17.74 & 4,880 \\
17.75 & 4,900 \\
17.76 & 4,920 \\
17.77 & 4,940 \\
17.78 & 4,950 \\
17.79 & 4,970 \\
17.80 & 4,990 \\
17.81 & 5,010 \\
17.82 & 5,020 \\
17.83 & 5,040 \\
17.84 & 5,060 \\
17.85 & 5,080 \\
17.86 & 5,090 \\
17.87 & 5,110 \\
\hline & \\
& \\
\hline
\end{tabular}




\begin{tabular}{rr}
\hline & \\
Stage & \multicolumn{1}{c}{ Flow } \\
(ft) & \multicolumn{1}{c}{ (cfs) } \\
\hline 17.88 & 5,130 \\
17.89 & 5,150 \\
17.9 & 5,160 \\
17.91 & 5,180 \\
17.92 & 5,200 \\
17.93 & 5,220 \\
17.94 & 5,230 \\
17.95 & 5,250 \\
17.96 & 5,270 \\
17.97 & 5,290 \\
17.98 & 5,300 \\
17.99 & 5,320 \\
18 & $.005,340$ \\
18.01 & 5,360 \\
18.02 & 5,370 \\
18.03 & 5,390 \\
18.04 & 5,410 \\
18.05 & 5,430 \\
18.06 & 5,450 \\
18.07 & 5,460 \\
18.08 & 5,480 \\
18.09 & 5,500 \\
18.10 & 5,520 \\
18.11 & 5,540 \\
18.12 & 5,550 \\
18.13 & 5,570 \\
18.14 & 5,590 \\
18.15 & 5,610 \\
18.16 & 5,620 \\
18.17 & 5,640 \\
18.18 & 5,660 \\
18.19 & 5,680 \\
18.20 & 5,700 \\
18.21 & 5,720 \\
18.22 & 5,730 \\
18.23 & 5,750 \\
18.24 & 5,770 \\
18.25 & 5,790 \\
18.26 & 5,810 \\
18.27 & 5,820 \\
18.28 & 5,840 \\
18.29 & 5,860 \\
18.30 & 5,880 \\
18.31 & 5,900 \\
18.32 & 5,920 \\
18.33 & 5,930 \\
18.34 & 5,950 \\
18.35 & 5,970 \\
18.36 & 5,990 \\
18.37 & 6,010 \\
.------ \\
& \\
\hline
\end{tabular}

\begin{tabular}{cc}
\hline & \\
\hline Stage & Flow \\
(ft) & (cfs) \\
\hline 18.38 & 6,030 \\
18.39 & 6,040 \\
18.40 & 6,060 \\
18.41 & 6,080 \\
18.42 & 6,100 \\
18.43 & 6,120 \\
18.44 & 6,140 \\
18.45 & 6,150 \\
18.46 & 6,170 \\
18.47 & 6,190 \\
18.48 & 6,210 \\
18.49 & 6,230 \\
18.50 & 6,250 \\
18.51 & 6,270 \\
18.52 & 6,280 \\
18.53 & 6,300 \\
18.54 & 6,320 \\
18.55 & 6,340 \\
18.56 & 6,360 \\
18.57 & 6,380 \\
18.58 & 6,400 \\
18.59 & 6,420 \\
18.60 & 6,430 \\
18.61 & 6,450 \\
18.62 & 6,470 \\
18.63 & 6,490 \\
18.64 & 6,510 \\
18.65 & 6,530 \\
18.66 & 6,550 \\
18.67 & 6,570 \\
18.68 & 6,590 \\
18.69 & 6,600 \\
18.70 & 6,620 \\
18.71 & 6,640 \\
18.72 & 6,660 \\
18.73 & 6,680 \\
18.74 & 6,700 \\
18.75 & 6,720 \\
18.76 & 6,740 \\
18.77 & 6,760 \\
18.78 & 6,780 \\
18.79 & 6,790 \\
18.80 & 6,810 \\
18.81 & 6,830 \\
18.82 & 6,850 \\
18.83 & 6,870 \\
18.84 & 6,890 \\
18.85 & 6,910 \\
18.86 & 6,930 \\
18.87 & 6,950 \\
\hline..-- \\
& \\
\hline
\end{tabular}

\begin{tabular}{cc} 
Stage & Flow \\
(ft) & (cfs) \\
\hline 18.88 & 6,970 \\
18.89 & 6,990 \\
18.90 & 7,010 \\
18.91 & 7,020 \\
18.92 & 7,040 \\
18.93 & 7,060 \\
18.94 & 7,080 \\
18.95 & 7,100 \\
18.96 & 7,120 \\
18.97 & 7,140 \\
18.98 & 7,160 \\
18.99 & 7,180 \\
19.00 & 7,200 \\
19.01 & 7,220 \\
19.02 & 7,240 \\
19.03 & 7,260 \\
19.04 & 7,280 \\
19.05 & 7,300 \\
19.06 & 7,320 \\
19.07 & 7,340 \\
19.08 & 7,360 \\
19.09 & 7,370 \\
19.10 & 7,390 \\
19.11 & 7,410 \\
19.12 & 7,430 \\
19.13 & 7,450 \\
19.14 & 7,470 \\
19.15 & 7,490 \\
19.16 & 7,510 \\
19.17 & 7,530 \\
19.18 & 7,550 \\
19.19 & 7,570 \\
19.20 & 7,590 \\
19.21 & 7,610 \\
19.22 & 7,630 \\
19.23 & 7,650 \\
19.24 & 7,670 \\
19.25 & 7,690 \\
19.26 & 7,710 \\
19.27 & 7,730 \\
19.28 & 7,750 \\
19.29 & 7,770 \\
19.30 & 7,790 \\
19.31 & 7,810 \\
19.32 & 7,830 \\
19.33 & 7,850 \\
19.34 & 7,870 \\
19.35 & 7,890 \\
19.36 & 7,910 \\
19.37 & 7,930 \\
\hline & \\
& \\
\hline
\end{tabular}




\begin{tabular}{cc} 
Stage & Flow \\
(ft) & (cfs) \\
\hline 19.38 & 7,950 \\
19.39 & 7,970 \\
19.40 & 7,990 \\
19.41 & 8,010 \\
19.42 & 8,030 \\
19.43 & 8,050 \\
19.44 & 8,070 \\
19.45 & 8,090 \\
19.46 & 8,110 \\
19.47 & 8,130 \\
19.48 & 8,150 \\
19.49 & 8,170 \\
19.50 & 8,190 \\
19.51 & 8,210 \\
19.52 & 8,230 \\
19.53 & 8,250 \\
19.54 & 8,270 \\
19.55 & 8,290 \\
19.56 & 8,310 \\
19.57 & 8,330 \\
19.58 & 8,350 \\
19.59 & 8,370 \\
19.60 & 8,390 \\
19.61 & 8,410 \\
19.62 & 8,440 \\
19.63 & 8,460 \\
19.64 & 8,480 \\
19.65 & 8,500 \\
19.66 & 8,520 \\
19.67 & 8,540 \\
19.68 & 8,560 \\
19.69 & 8,580 \\
19.70 & 8,600 \\
19.71 & 8,620 \\
19.72 & 8,640 \\
19.73 & 8,660 \\
19.74 & 8,680 \\
19.75 & 8,700 \\
19.76 & 8,720 \\
19.77 & 8,740 \\
19.78 & 8,760 \\
19.79 & 8,780 \\
19.80 & 8,810 \\
19.81 & 8,830 \\
19.82 & 8,850 \\
19.83 & 8,870 \\
19.84 & 8,890 \\
19.85 & 8,910 \\
19.86 & 8,930 \\
19.87 & 8,950 \\
.------ \\
& \\
\hline
\end{tabular}

\begin{tabular}{|c|c|c|c|}
\hline $\begin{array}{c}\text { Stage } \\
(\mathrm{ft})\end{array}$ & $\begin{array}{l}\text { Flow } \\
(\mathrm{cfs})\end{array}$ & $\begin{array}{c}\text { Stage } \\
(\mathrm{ft})\end{array}$ & $\begin{array}{l}\text { Flow } \\
\text { (cfs) }\end{array}$ \\
\hline $\begin{array}{l}19.88 \\
\end{array}$ & 8,970 & 20.38 & 10,000 \\
\hline 19.89 & 8,990 & 20.39 & 10,100 \\
\hline 19.90 & 9,010 & 20.40 & 10,100 \\
\hline 19.91 & 9,030 & 20.41 & 10,100 \\
\hline 19.92 & 9,060 & 20.42 & 10,100 \\
\hline 19.93 & 9,080 & 20.43 & 10,100 \\
\hline 19.94 & 9,100 & 20.44 & 10,200 \\
\hline 19.95 & 9,120 & 20.45 & 10,200 \\
\hline 19.96 & 9,140 & 20.46 & 10,200 \\
\hline 19.97 & 9,160 & 20.47 & 10,200 \\
\hline 19.98 & 9,180 & 20.48 & 10,200 \\
\hline 19.99 & 9,200 & 20.49 & 10,300 \\
\hline 20.00 & 9,220 & 20.50 & 10,300 \\
\hline 20.01 & 9,240 & 20.51 & 10,300 \\
\hline 20.02 & 9,260 & 20.52 & 10,300 \\
\hline 20.03 & 9,290 & 20.53 & 10,400 \\
\hline 20.04 & 9,310 & 20.54 & 10,400 \\
\hline 20.05 & 9,330 & 20.55 & 10,400 \\
\hline 20.06 & 9,350 & 20.56 & 10,400 \\
\hline 20.07 & 9,370 & 20.57 & 10,400 \\
\hline 20.08 & 9,390 & 20.58 & 10,500 \\
\hline 20.09 & 9,410 & 20.59 & 10,500 \\
\hline 20.10 & 9,430 & 20.60 & 10,500 \\
\hline 20.11 & 9,450 & 20.61 & 10,500 \\
\hline 20.12 & 9,480 & 20.62 & 10,600 \\
\hline 20.13 & 9,500 & 20.63 & 10,600 \\
\hline 20.14 & 9,520 & 20.64 & 10,600 \\
\hline 20.15 & 9,540 & 20.65 & 10,600 \\
\hline 20.16 & 9,560 & 20.66 & 10,600 \\
\hline 20.17 & 9,580 & 20.67 & 10,700 \\
\hline 20.18 & 9,600 & 20.68 & 10,700 \\
\hline 20.19 & 9,620 & 20.69 & 10,700 \\
\hline 20.20 & 9,650 & 20.70 & 10,700 \\
\hline 20.21 & 9,670 & 20.71 & 10,800 \\
\hline 20.22 & 9,690 & 20.72 & 10,800 \\
\hline 20.23 & 9,710 & 20.73 & 10,800 \\
\hline 20.24 & 9,730 & 20.74 & 10,800 \\
\hline 20.25 & 9,750 & 20.75 & 10,800 \\
\hline 20.26 & 9,770 & 20.76 & 10,900 \\
\hline 20.27 & 9,800 & 20.77 & 10,900 \\
\hline 20.28 & 9,820 & 20.78 & 10,900 \\
\hline 20.29 & 9,840 & 20.79 & 10,900 \\
\hline 20.30 & 9,860 & 20.80 & 10,900 \\
\hline 20.31 & 9,880 & 20.81 & 11,000 \\
\hline 20.32 & 9,900 & 20.82 & 11,000 \\
\hline 20.33 & 9,920 & 20.83 & 11,000 \\
\hline 20.34 & 9,950 & 20.84 & 11,000 \\
\hline 20.35 & 9,970 & 20.85 & 11,100 \\
\hline 20.36 & 9,990 & 20.86 & 11,100 \\
\hline 20.37 & 10,000 & 20.87 & 11,100 \\
\hline
\end{tabular}




\begin{tabular}{cl}
\hline Stage & Flow \\
(ft) & (cfs) \\
\hline 20.88 & 11,100 \\
20.89 & 11,100 \\
20.90 & 11,200 \\
20.91 & 11,200 \\
20.92 & 11,200 \\
20.93 & 11,200 \\
20.94 & 11,300 \\
20.95 & 11,300 \\
20.96 & 11,300 \\
20.97 & 11,300 \\
20.98 & 11,400 \\
20.99 & 11,400 \\
21.00 & 11,400 \\
21.01 & 11,400 \\
21.02 & 11,400 \\
21.03 & 11,500 \\
21.04 & 11,500 \\
21.05 & 11,500 \\
21.06 & 11,500 \\
21.07 & 11,600 \\
21.08 & 11,600 \\
21.09 & 11,600 \\
21.10 & 11,600 \\
21.11 & 11,600 \\
21.12 & 11,700 \\
21.13 & 11,700 \\
21.14 & 11,700 \\
21.15 & 11,700 \\
21.16 & 11,800 \\
21.17 & 11,800 \\
21.18 & 11,800 \\
21.19 & 11,800 \\
21.20 & 11,800 \\
21.21 & 11,900 \\
21.22 & 11,900 \\
21.23 & 11,900 \\
21.24 & 11,900 \\
21.25 & 12,000 \\
21.26 & 12,000 \\
21.27 & 12,000 \\
21.28 & 12,000 \\
21.29 & 12,100 \\
21.30 & 12,100 \\
21.31 & 12,100 \\
21.32 & 12,100 \\
21.33 & 12,100 \\
21.34 & 12,200 \\
21.35 & 12,200 \\
21.36 & 12,200 \\
21.37 & 12,200 \\
..---- \\
& \\
\hline
\end{tabular}

\begin{tabular}{|c|c|c|c|}
\hline $\begin{array}{l}\text { Stage } \\
(\mathrm{ft})\end{array}$ & $\begin{array}{l}\text { Flow } \\
\text { (cfs) }\end{array}$ & $\begin{array}{l}\text { Stage } \\
(\mathrm{ft})\end{array}$ & $\begin{array}{l}\text { Flow } \\
\text { (cfs) }\end{array}$ \\
\hline 21.38 & 12,300 & 21.88 & 13,400 \\
\hline 21.39 & 12,300 & 21.89 & 13,400 \\
\hline 21.40 & 12,300 & 21.90 & 13,500 \\
\hline 21.41 & 12,300 & 21.91 & 13,500 \\
\hline 21.42 & 12,300 & 21.92 & 13,500 \\
\hline 21.43 & 12,400 & 21.93 & 13,500 \\
\hline 21.44 & 12,400 & 21.94 & 13,600 \\
\hline 21.45 & 12,400 & 21.95 & 13,600 \\
\hline 21.46 & 12,400 & 21.96 & 13,600 \\
\hline 21.47 & 12,500 & 21.97 & 13,600 \\
\hline 21.48 & 12,500 & 21.98 & 13,700 \\
\hline 21.49 & 12,500 & 21.99 & 13,700 \\
\hline 21.50 & 12,500 & 22.00 & 13,700 \\
\hline 21.51 & 12,600 & 22.01 & 13,700 \\
\hline 21.52 & 12,600 & 22.02 & 13,800 \\
\hline 21.53 & 12,600 & 22.03 & 13,800 \\
\hline 21.54 & 12,600 & 22.04 & 13,800 \\
\hline 21.55 & 12,600 & 22.05 & 13,800 \\
\hline 21.56 & 12,700 & 22.06 & 13,800 \\
\hline 21.57 & 12,700 & 22.07 & 13,900 \\
\hline 21.58 & 12,700 & 22.08 & 13,900 \\
\hline 21.59 & 12,700 & 22.09 & 13,900 \\
\hline 21.60 & 12,800 & 22.10 & 13,900 \\
\hline 21.61 & 12,800 & 22.11 & 14,000 \\
\hline 21.62 & 12,800 & 22.12 & 14,000 \\
\hline 21.63 & 12,800 & 22.13 & 14,000 \\
\hline 21.64 & 12,900 & 22.14 & 14,000 \\
\hline 21.65 & 12,900 & 22.15 & 14,100 \\
\hline 21.66 & 12,900 & 22.16 & 14,100 \\
\hline 21.67 & 12,900 & 22.17 & 14,100 \\
\hline 21.68 & 13,000 & 22.18 & 14,100 \\
\hline 21.69 & 13,000 & 22.19 & 14,200 \\
\hline 21.70 & 13,000 & 22.20 & 14,200 \\
\hline 21.71 & 13,000 & 22.21 & 14,200 \\
\hline 21.72 & 13,000 & 22.22 & 14,200 \\
\hline 21.73 & 13,100 & 22.23 & 14,300 \\
\hline 21.74 & 13,100 & 22.24 & 14,300 \\
\hline 21.75 & 13,100 & 22.25 & 14,300 \\
\hline 21.76 & 13,100 & 22.26 & 14,300 \\
\hline 21.77 & 13,200 & 22.27 & 14,400 \\
\hline 21.78 & 13,200 & 22.28 & 14,400 \\
\hline 21.79 & 13,200 & 22.29 & 14,400 \\
\hline 21.80 & 13,200 & 22.30 & 14,400 \\
\hline 21.81 & 13,300 & 22.31 & 14,400 \\
\hline 21.82 & 13,300 & 22.32 & 14,500 \\
\hline 21.83 & 13,300 & 22.33 & 14,500 \\
\hline 21.84 & 13,300 & 22.34 & 14,500 \\
\hline 21.85 & 13,300 & 22.35 & 14,500 \\
\hline 21.86 & 13,400 & 22.36 & 14,600 \\
\hline 21.87 & 13,400 & 22.37 & 14,600 \\
\hline
\end{tabular}




\begin{tabular}{cc} 
Stage & Flow \\
(ft) & (cfs) \\
\hline 22.38 & 14,600 \\
22.39 & 14,600 \\
22.40 & 14,700 \\
22.41 & 14,700 \\
22.42 & 14,700 \\
22.43 & 14,700 \\
22.44 & 14,800 \\
22.45 & 14,800 \\
22.46 & 14,800 \\
22.47 & 14,800 \\
22.48 & 14,900 \\
22.49 & 14,900 \\
22.50 & 14,900 \\
22.51 & 14,900 \\
22.52 & 15,000 \\
22.53 & 15,000 \\
22.54 & 15,000 \\
22.55 & 15,000 \\
22.56 & 15,100 \\
22.57 & 15,100 \\
22.58 & 15,100 \\
22.59 & 15,100 \\
22.60 & 15,200 \\
22.61 & 15,200 \\
22.62 & 15,200 \\
22.63 & 15,200 \\
22.64 & 15,300 \\
22.65 & 15,300 \\
22.66 & 15,300 \\
22.67 & 15,300 \\
22.68 & 15,300 \\
22.69 & 15,400 \\
22.70 & 15,400 \\
22.71 & 15,400 \\
22.72 & 15,400 \\
22.73 & 15,500 \\
22.74 & 15,500 \\
22.75 & 15,500 \\
22.76 & 15,500 \\
22.77 & 15,600 \\
22.78 & 15,600 \\
22.79 & 15,600 \\
22.80 & 15,600 \\
22.81 & 15,700 \\
22.82 & 15,700 \\
22.83 & 15,700 \\
--.87 & 15,700 \\
& 15,800 \\
& 15,800 \\
$22 .--$ & \\
$22--$ \\
2.
\end{tabular}

\begin{tabular}{cl}
\hline Stage & Flow \\
(ft) & (cfs) \\
\hline 22.88 & 15,800 \\
22.89 & 15,900 \\
22.90 & 15,900 \\
22.91 & 15,900 \\
22.92 & 15,900 \\
22.93 & 16,000 \\
22.94 & 16,000 \\
22.95 & 16,000 \\
22.96 & 16,000 \\
22.97 & 16,100 \\
22.98 & 16,100 \\
22.99 & 16,100 \\
23.00 & 16,100 \\
23.01 & 16,200 \\
23.02 & 16,200 \\
23.03 & 16,200 \\
23.04 & 16,200 \\
23.05 & 16,300 \\
23.06 & 16,300 \\
23.07 & 16,300 \\
23.08 & 16,300 \\
23.09 & 16,400 \\
23.10 & 16,400 \\
23.11 & 16,400 \\
23.12 & 16,400 \\
23.13 & 16,500 \\
23.14 & 16,500 \\
23.15 & 16,500 \\
23.16 & 16,500 \\
23.17 & 16,600 \\
23.18 & 16,600 \\
23.19 & 16,600 \\
23.20 & 16,600 \\
23.21 & 16,700 \\
23.22 & 16,700 \\
23.23 & 16,700 \\
23.24 & 16,700 \\
23.25 & 16,800 \\
23.26 & 16,800 \\
23.27 & 16,800 \\
23.28 & 16,800 \\
23.29 & 16,900 \\
23.30 & 16,900 \\
23.31 & 16,900 \\
23.32 & 16,900 \\
23.33 & 17,000 \\
23.34 & 17,000 \\
23.35 & 17,000 \\
23.36 & 17,000 \\
23.37 & 17,100 \\
..---- \\
& \\
\hline
\end{tabular}

\begin{tabular}{|c|c|}
\hline $\begin{array}{l}\text { Stage } \\
(\mathrm{ft})\end{array}$ & $\begin{array}{l}\text { Flow } \\
\text { (cfs) }\end{array}$ \\
\hline 23.38 & 17,100 \\
\hline 23.39 & 17,100 \\
\hline 23.40 & 17,200 \\
\hline 23.41 & 17,200 \\
\hline 23.42 & 17,200 \\
\hline 23.43 & 17,200 \\
\hline 23.44 & 17,300 \\
\hline 23.45 & 17,300 \\
\hline 23.46 & 17,300 \\
\hline 23.47 & 17,300 \\
\hline 23.48 & 17,400 \\
\hline 23.49 & 17,400 \\
\hline 23.50 & 17,400 \\
\hline 23.51 & 17,400 \\
\hline 23.52 & 17,500 \\
\hline 23.53 & 17,500 \\
\hline 23.54 & 17,500 \\
\hline 23.55 & 17,500 \\
\hline 23.56 & 17,600 \\
\hline 23.57 & 17,600 \\
\hline 23.58 & 17,600 \\
\hline 23.59 & 17,600 \\
\hline 23.60 & 17,700 \\
\hline 23.61 & 17,700 \\
\hline 23.62 & 17,700 \\
\hline 23.63 & 17,700 \\
\hline 23.64 & 17,800 \\
\hline 23.65 & 17,800 \\
\hline 23.66 & 17,800 \\
\hline 23.67 & 17,800 \\
\hline 23.68 & 17,900 \\
\hline 23.69 & 17,900 \\
\hline 23.70 & 17,900 \\
\hline 23.71 & 17,900 \\
\hline 23.72 & 18,000 \\
\hline 23.73 & 18,000 \\
\hline 23.74 & 18,000 \\
\hline 23.75 & 18,000 \\
\hline 23.76 & 18,100 \\
\hline 23.77 & 18,100 \\
\hline 23.78 & 18,100 \\
\hline 23.79 & 18,200 \\
\hline 23.80 & 18,200 \\
\hline 23.81 & 18,200 \\
\hline 23.82 & 18,200 \\
\hline 23.83 & 18,300 \\
\hline 23.84 & 18,300 \\
\hline 23.85 & 18,300 \\
\hline 23.86 & 18,300 \\
\hline 23.87 & 18,400 \\
\hline
\end{tabular}




\begin{tabular}{cc}
\hline Stage & Flow \\
(ft) & (cfs) \\
\hline 23.88 & 18,400 \\
23.89 & 18,400 \\
23.90 & 18,400 \\
23.91 & 18,500 \\
23.92 & 18,500 \\
23.93 & 18,500 \\
23.94 & 18,500 \\
23.95 & 18,600 \\
23.96 & 18,600 \\
23.97 & 18,600 \\
23.98 & 18,600 \\
23.99 & 18,700 \\
24.00 & 18,700 \\
24.01 & 18,700 \\
24.02 & 18,800 \\
24.03 & 18,800 \\
24.04 & 18,800 \\
24.05 & 18,800 \\
24.06 & 18,900 \\
24.07 & 18,900 \\
24.08 & 18,900 \\
24.09 & 18,900 \\
24.10 & 19,000 \\
24.11 & 19,000 \\
24.12 & 19,000 \\
24.13 & 19,000 \\
24.14 & 19,100 \\
24.15 & 19,100 \\
24.16 & 19,100 \\
24.17 & 19,100 \\
24.18 & 19,200 \\
24.19 & 19,200 \\
24.20 & 19,200 \\
24.21 & 19,300 \\
24.22 & 19,300 \\
24.23 & 19,300 \\
24.24 & 19,300 \\
24.25 & 19,400 \\
24.26 & 19,400 \\
24.27 & 19,400 \\
24.28 & 19,400 \\
24.29 & 19,500 \\
24.30 & 19,500 \\
24.31 & 19,500 \\
24.32 & 19,500 \\
24.33 & 19,600 \\
24.34 & 19,600 \\
24.35 & 19,600 \\
24.36 & 19,600 \\
24.37 & 19,700 \\
------ \\
&
\end{tabular}

\begin{tabular}{|c|c|c|c|}
\hline $\begin{array}{l}\text { Stage } \\
(\mathrm{ft})\end{array}$ & $\begin{array}{l}\text { Flow } \\
\text { (cfs) }\end{array}$ & $\begin{array}{l}\text { Stage } \\
(\mathrm{ft})\end{array}$ & $\begin{array}{l}\text { Flow } \\
\text { (cfs) }\end{array}$ \\
\hline 24.38 & 19,700 & 24.88 & 21,000 \\
\hline 24.39 & 19,700 & 24.89 & 21,100 \\
\hline 24.40 & 19,800 & 24.90 & 21,100 \\
\hline 24.41 & 19,800 & 24.91 & 21,100 \\
\hline 24.42 & 19,800 & 24.92 & 21,200 \\
\hline 24.43 & 19,800 & 24.93 & 21,200 \\
\hline 24.44 & 19,900 & 24.94 & 21,200 \\
\hline 24.45 & 19,900 & 24.95 & 21,200 \\
\hline 24.46 & 19,900 & 24.96 & 21,300 \\
\hline 24.47 & 19,900 & 24.97 & 21,300 \\
\hline 24.48 & 20,000 & 24.98 & 21,300 \\
\hline 24.49 & 20,000 & 24.99 & 21,300 \\
\hline 24.50 & 20,000 & 25.00 & 21,400 \\
\hline 24.51 & 20,000 & 25.01 & 21,400 \\
\hline 24.52 & 20,100 & 25.02 & 21,400 \\
\hline 24.53 & 20,100 & 25.03 & 21,500 \\
\hline 24.54 & 20,100 & 25.04 & 21,500 \\
\hline 24.55 & 20,200 & 25.05 & 21,500 \\
\hline 24.56 & 20,200 & 25.06 & 21,500 \\
\hline 24.57 & 20,200 & 25.07 & 21,600 \\
\hline 24.58 & 20,200 & 25.08 & 21,600 \\
\hline 24.59 & 20,300 & 25.09 & 21,600 \\
\hline 24.60 & 20,300 & 25.10 & 21,600 \\
\hline 24.61 & 20,300 & 25.11 & 21,700 \\
\hline 24.62 & 20,300 & 25.12 & 21,700 \\
\hline 24.63 & 20,400 & 25.13 & 21,700 \\
\hline 24.64 & 20,400 & 25.14 & 21,800 \\
\hline 24.65 & 20,400 & 25.15 & 21,800 \\
\hline 24.66 & 20,500 & 25.16 & 21,800 \\
\hline 24.67 & 20,500 & 25.17 & 21,800 \\
\hline 24.68 & 20,500 & 25.18 & 21,900 \\
\hline 24.69 & 20,500 & 25.19 & 21,900 \\
\hline 24.70 & 20,600 & 25.20 & 21,900 \\
\hline 24.71 & 20,600 & 25.21 & 21,900 \\
\hline 24.72 & 20,600 & 25.22 & 22,000 \\
\hline 24.73 & 20,600 & 25.23 & 22,000 \\
\hline 24.74 & 20,700 & 25.24 & 22,000 \\
\hline 24.75 & 20,700 & 25.25 & 22,100 \\
\hline 24.76 & 20,700 & 25.26 & 22,100 \\
\hline 24.77 & 20,700 & 25.27 & 22,100 \\
\hline 24.78 & 20,800 & 25.28 & 22,100 \\
\hline 24.79 & 20,800 & 25.29 & 22,200 \\
\hline 24.80 & 20,800 & 25.30 & 22,200 \\
\hline 24.81 & 20,900 & 25.31 & 22,200 \\
\hline 24.82 & 20,900 & 25.32 & 22,200 \\
\hline 24.83 & 20,900 & 25.33 & 22,300 \\
\hline 24.84 & 20,900 & 25.34 & 22,300 \\
\hline 24.85 & 21,000 & 25.35 & 22,300 \\
\hline 24.86 & 21,000 & 25.36 & 22,400 \\
\hline 24.87 & 21,000 & 25.37 & 22,400 \\
\hline
\end{tabular}




\begin{tabular}{cl}
\hline & \\
Stage & Flow \\
(ft) & (cfs) \\
\hline 25.38 & 22,400 \\
25.39 & 22,400 \\
25.40 & 22,500 \\
25.41 & 22,500 \\
25.42 & 22,500 \\
25.43 & 22,600 \\
25.44 & 22,600 \\
25.45 & 22,600 \\
25.46 & 22,600 \\
25.47 & 22,700 \\
25.48 & 22,700 \\
25.49 & 22,700 \\
25.50 & 22,700 \\
25.51 & 22,800 \\
25.52 & 22,800 \\
25.53 & 22,800 \\
25.54 & 22,900 \\
25.55 & 22,900 \\
25.56 & 22,900 \\
25.57 & 22,900 \\
25.58 & 23,000 \\
25.59 & 23,000 \\
25.60 & 23,000 \\
25.61 & 23,100 \\
25.62 & 23,100 \\
25.63 & 23,100 \\
25.64 & 23,100 \\
25.65 & 23,200 \\
25.66 & 23,200 \\
25.67 & 23,200 \\
25.68 & 23,300 \\
25.69 & 23,300 \\
25.70 & 23,300 \\
25.71 & 23,400 \\
25.72 & 23,400 \\
25.73 & 23,400 \\
25.74 & 23,400 \\
25.75 & 23,500 \\
25.76 & 23,500 \\
25.77 & 23,500 \\
25.78 & 23,600 \\
25.79 & 23,600 \\
25.80 & 23,600 \\
25.81 & 23,700 \\
25.82 & 23,700 \\
25.83 & 23,700 \\
25.84 & 23,800 \\
25.85 & 23,800 \\
25.86 & 23,800 \\
25.87 & 23,900 \\
..---- \\
& \\
\hline--
\end{tabular}

\begin{tabular}{cl}
\hline & \\
Stage & Flow \\
(ft) & (cfs) \\
\hline 25.88 & 23,900 \\
25.89 & 23,900 \\
25.90 & 24,000 \\
25.91 & 24,000 \\
25.92 & 24,000 \\
25.93 & 24,100 \\
25.94 & 24,100 \\
25.95 & 24,100 \\
25.96 & 24,200 \\
25.97 & 24,200 \\
25.98 & 24,200 \\
25.99 & 24,200 \\
26.00 & 24,300 \\
26.01 & 24,300 \\
26.02 & 24,300 \\
26.03 & 24,400 \\
26.04 & 24,400 \\
26.05 & 24,400 \\
26.06 & 24,500 \\
26.07 & 24,500 \\
26.08 & 24,500 \\
26.09 & 24,600 \\
26.10 & 24,600 \\
26.11 & 24,600 \\
26.12 & 24,700 \\
26.13 & 24,700 \\
26.14 & 24,700 \\
26.15 & 24,800 \\
26.16 & 24,800 \\
26.17 & 24,800 \\
26.18 & 24,900 \\
26.19 & 24,900 \\
26.20 & 24,900 \\
26.21 & 25,000 \\
26.22 & 25,000 \\
26.23 & 25,000 \\
26.24 & 25,100 \\
26.25 & 25,100 \\
26.26 & 25,100 \\
26.27 & 25,200 \\
26.28 & 25,200 \\
26.29 & 25,200 \\
26.30 & 25,300 \\
26.31 & 25,300 \\
26.32 & 25,300 \\
26.33 & 25,300 \\
26.34 & 25,400 \\
26.35 & 25,400 \\
26.36 & 25,400 \\
26.37 & 25,500 \\
..---- \\
& \\
\hline
\end{tabular}

\begin{tabular}{cl}
\hline & \\
Stage & Flow \\
(ft) & (cfs) \\
\hline 26.38 & 25,500 \\
26.39 & 25,500 \\
26.40 & 25,600 \\
26.41 & 25,600 \\
26.42 & 25,600 \\
26.43 & 25,700 \\
26.44 & 25,700 \\
26.45 & 25,700 \\
26.46 & 25,800 \\
26.47 & 25,800 \\
26.48 & 25,800 \\
26.49 & 25,800 \\
26.50 & 25,900 \\
26.51 & 25,900 \\
26.52 & 25,900 \\
26.53 & 26,000 \\
26.54 & 26,000 \\
26.55 & 26,000 \\
26.56 & 26,000 \\
26.57 & 26,100 \\
26.58 & 26,100 \\
26.59 & 26,200 \\
26.60 & 26,200 \\
26.61 & 26,200 \\
26.62 & 26,300 \\
26.63 & 26,300 \\
26.64 & 26,400 \\
26.65 & 26,400 \\
26.66 & 26,500 \\
26.67 & 26,500 \\
26.68 & 26,600 \\
26.69 & 26,600 \\
26.70 & 26,600 \\
26.71 & 26,700 \\
26.72 & 26,700 \\
26.73 & 26,800 \\
26.74 & 26,800 \\
26.75 & 26,900 \\
26.76 & 26,900 \\
26.77 & 26,900 \\
26.78 & 27,000 \\
26.79 & 27,000 \\
26.80 & 27,100 \\
26.81 & 27,100 \\
26.82 & 27,200 \\
26.83 & 27,200 \\
26.84 & 27,300 \\
26.85 & 27,300 \\
26.86 & 27,300 \\
26.87 & 27,400 \\
$2 .--$ \\
& \\
\hline
\end{tabular}




\begin{tabular}{cc}
\hline $\begin{array}{c}\text { Stage } \\
\text { (ft) }\end{array}$ & $\begin{array}{c}\text { Flow } \\
\text { (cfs) }\end{array}$ \\
\hline 26.88 & 27,400 \\
26.89 & 27,500 \\
26.90 & 27,500 \\
26.91 & 27,600 \\
26.92 & 27,600 \\
26.93 & 27,700 \\
26.94 & 27,700 \\
26.95 & 27,700 \\
26.96 & 27,800 \\
26.97 & 27,800 \\
26.98 & 27,900 \\
26.99 & 27,900 \\
27.00 & 28,000 \\
27.01 & 28,000 \\
27.02 & 28,100 \\
\hline.......----
\end{tabular}

\begin{tabular}{cl}
\hline $\begin{array}{c}\text { Stage } \\
\text { (ft) }\end{array}$ & $\begin{array}{c}\text { Flow } \\
\text { (cfs) }\end{array}$ \\
\hline 27.03 & 28,100 \\
27.04 & 28,200 \\
27.05 & 28,200 \\
27.06 & 28,200 \\
27.07 & 28,300 \\
27.08 & 28,300 \\
27.09 & 28,400 \\
27.10 & 28,400 \\
27.11 & 28,500 \\
27.12 & 28,500 \\
27.13 & 28,600 \\
27.14 & 28,600 \\
27.15 & 28,700 \\
27.16 & 28,700 \\
27.17 & 28,700 \\
\hline......
\end{tabular}

\begin{tabular}{cc}
\hline $\begin{array}{c}\text { Stage } \\
\text { (ft) }\end{array}$ & $\begin{array}{c}\text { Flow } \\
\text { (cfs) }\end{array}$ \\
\hline 27.18 & 28,800 \\
27.19 & 28,800 \\
27.20 & 28,900 \\
27.21 & 28,900 \\
27.22 & 29,000 \\
27.23 & 29,000 \\
27.24 & 29,100 \\
27.25 & 29,100 \\
27.26 & 29,200 \\
27.27 & 29,200 \\
27.28 & 29,200 \\
27.29 & 29,300 \\
27.30 & 29,300 \\
27.31 & 29,400 \\
27.32 & 29,400 \\
\hline
\end{tabular}




\section{APPENDIX B:}

MIDDLE GREEN RIVER FLOODPLAIN WETLAND CONNECTION MAPS FOR 2012 
This page intentionally left blank. 


\section{APPENDIX B:}

\section{MIDDLE GREEN RIVER FLOODPLAIN WETLAND CONNECTION MAPS FOR 2012}

This appendix presents overlays of modeled flow connections on aerial imagery of levee breaches and connection channels for floodplain wetlands surveyed in October 2012. The flow and cross section at which connection is estimated to occur is presented on each figure. For all images shown in the following figures, the date of the aerial imagery differs from the date of the survey, and aerial imagery does not depict exact conditions at the time of the survey. 
This page intentionally left blank. 

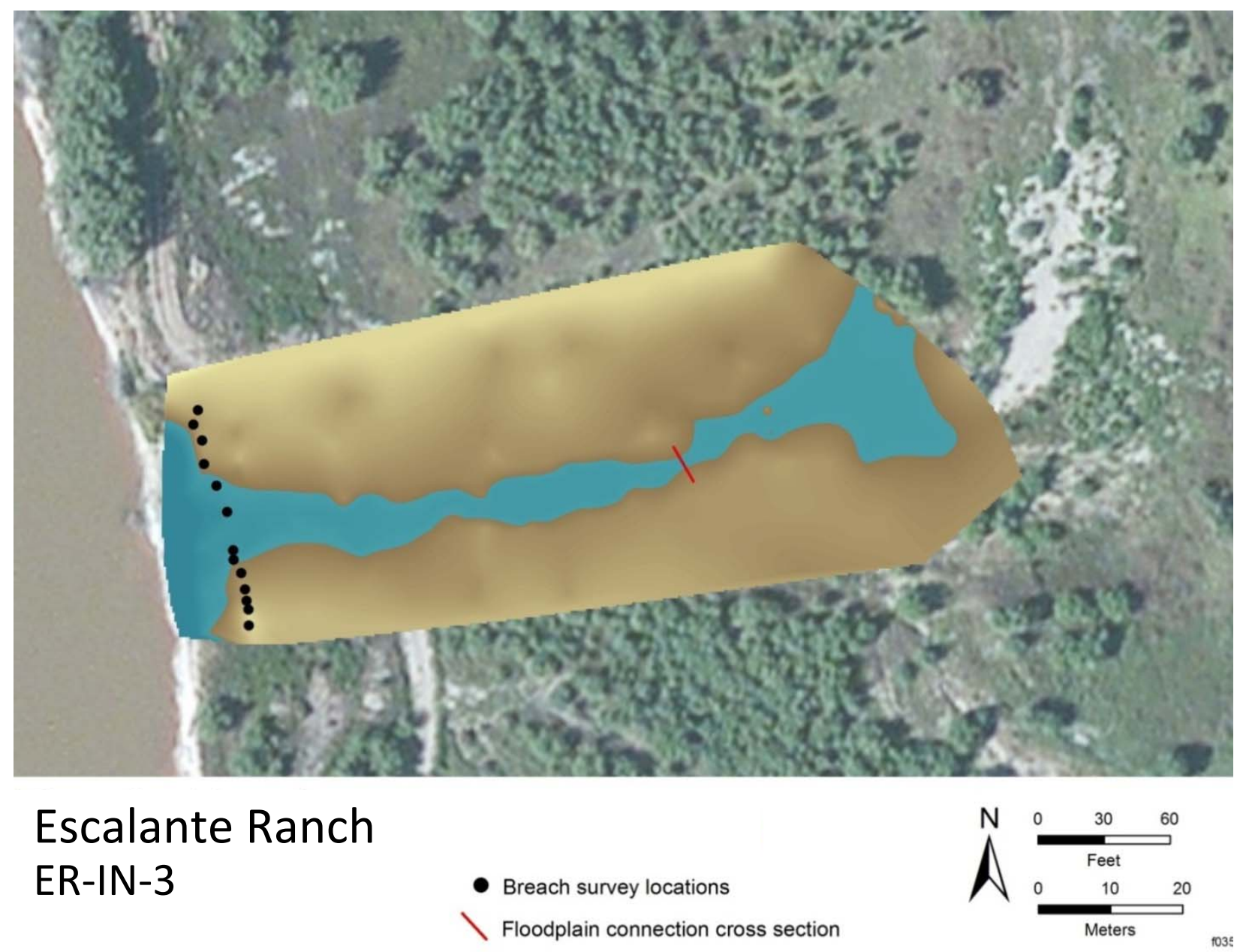

FIGURE B-1 Floodplain Wetland Connection Channel and Minimum Connection Cross Section for ER-IN-3 at 18,100 cfs in 2012 


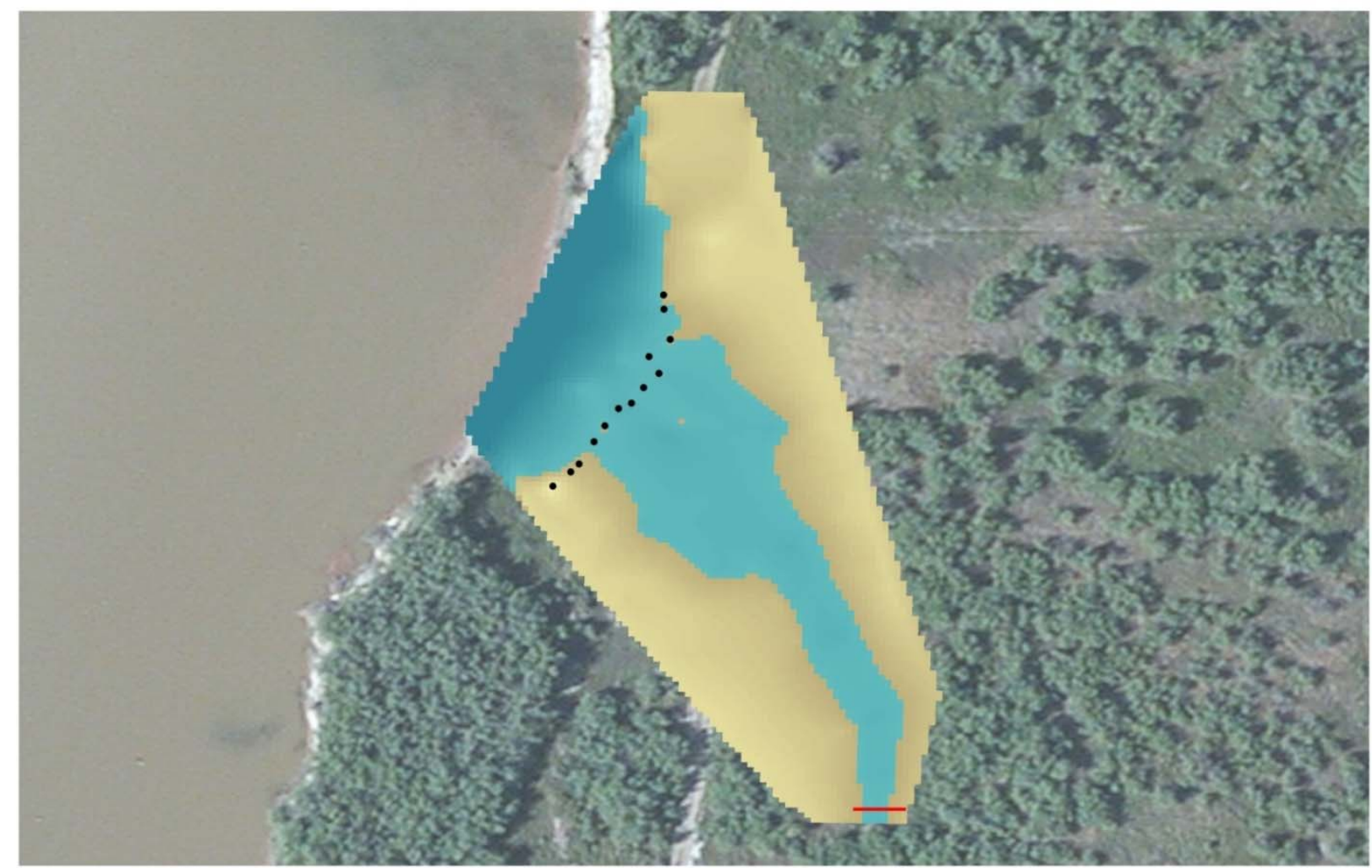

\section{Escalante Ranch} ER-IN-4

- Breach survey locations

Floodplain connection cross section

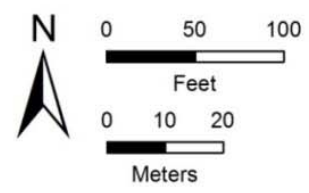

1036

FIGURE B-2 Floodplain Wetland Connection Channel and Minimum Connection Cross Section for ER-IN-4 at 20,300 cfs in 2012 


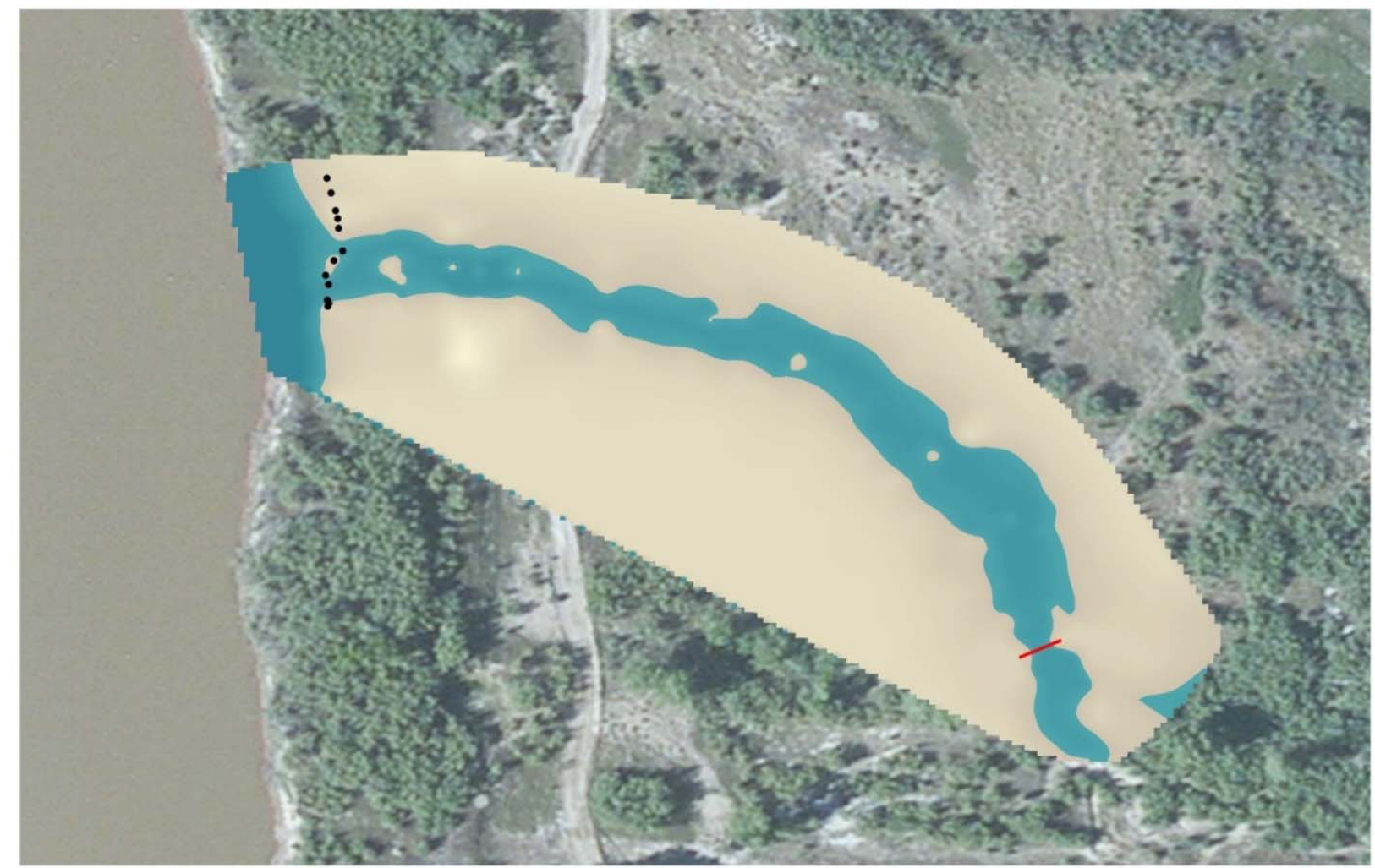

\section{Escalante Ranch} ER-IN-5

- Breach survey locations

Floodplain connection cross section

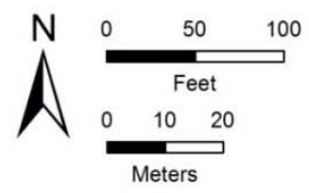

1037

FIGURE B-3 Floodplain Wetland Connection Channel and Minimum Connection Cross Section for ER-IN-5 at 16,800 cfs in 2012 


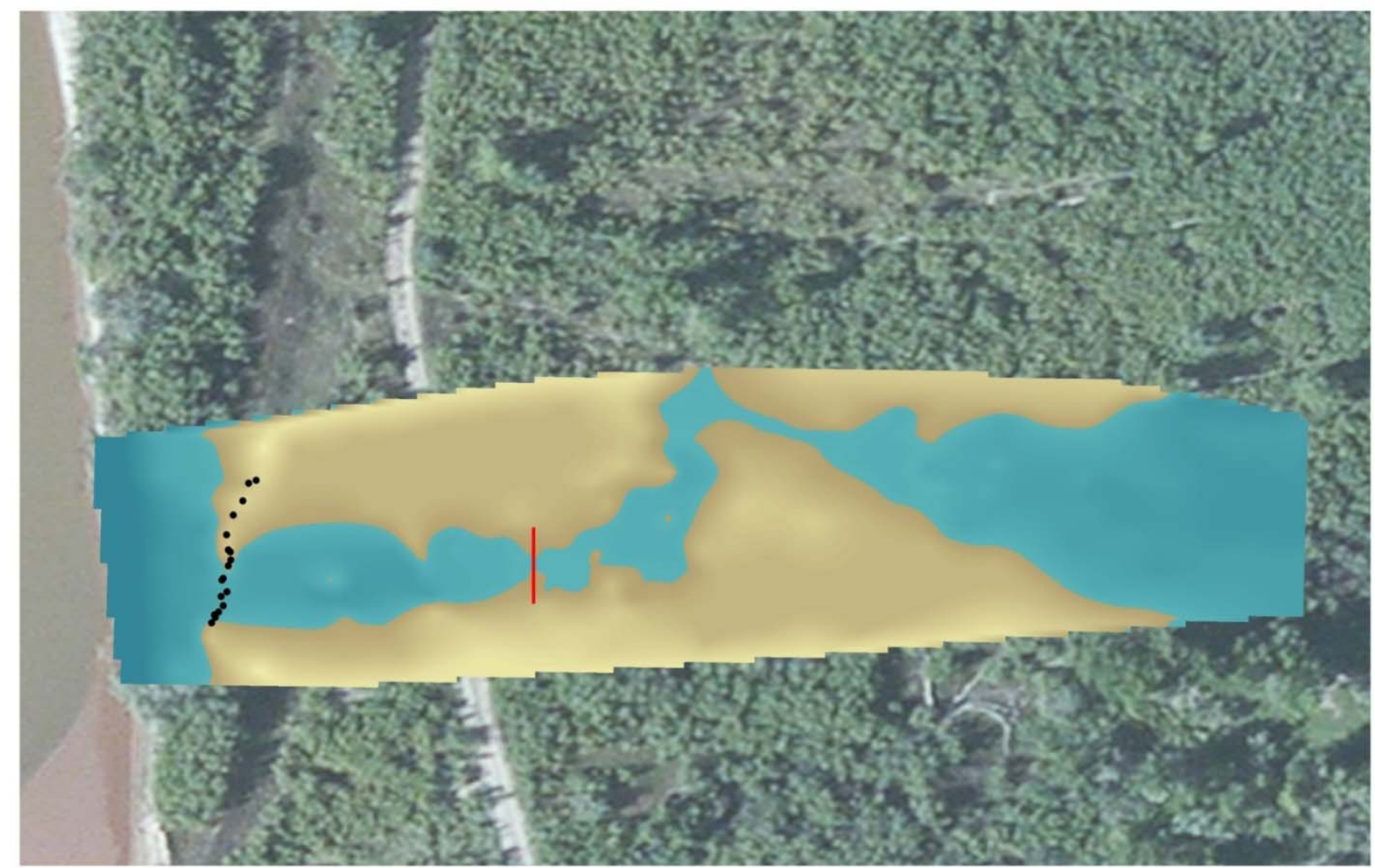

\section{Escalante Ranch ER-IN-6}

- Breach survey locations

| Floodplain connection cross section

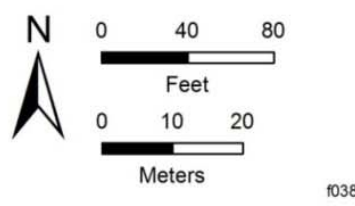

FIGURE B-4 Floodplain Wetland Connection Channel and Minimum Connection Cross Section for ER-IN-6 at 19,200 cfs in 2012 

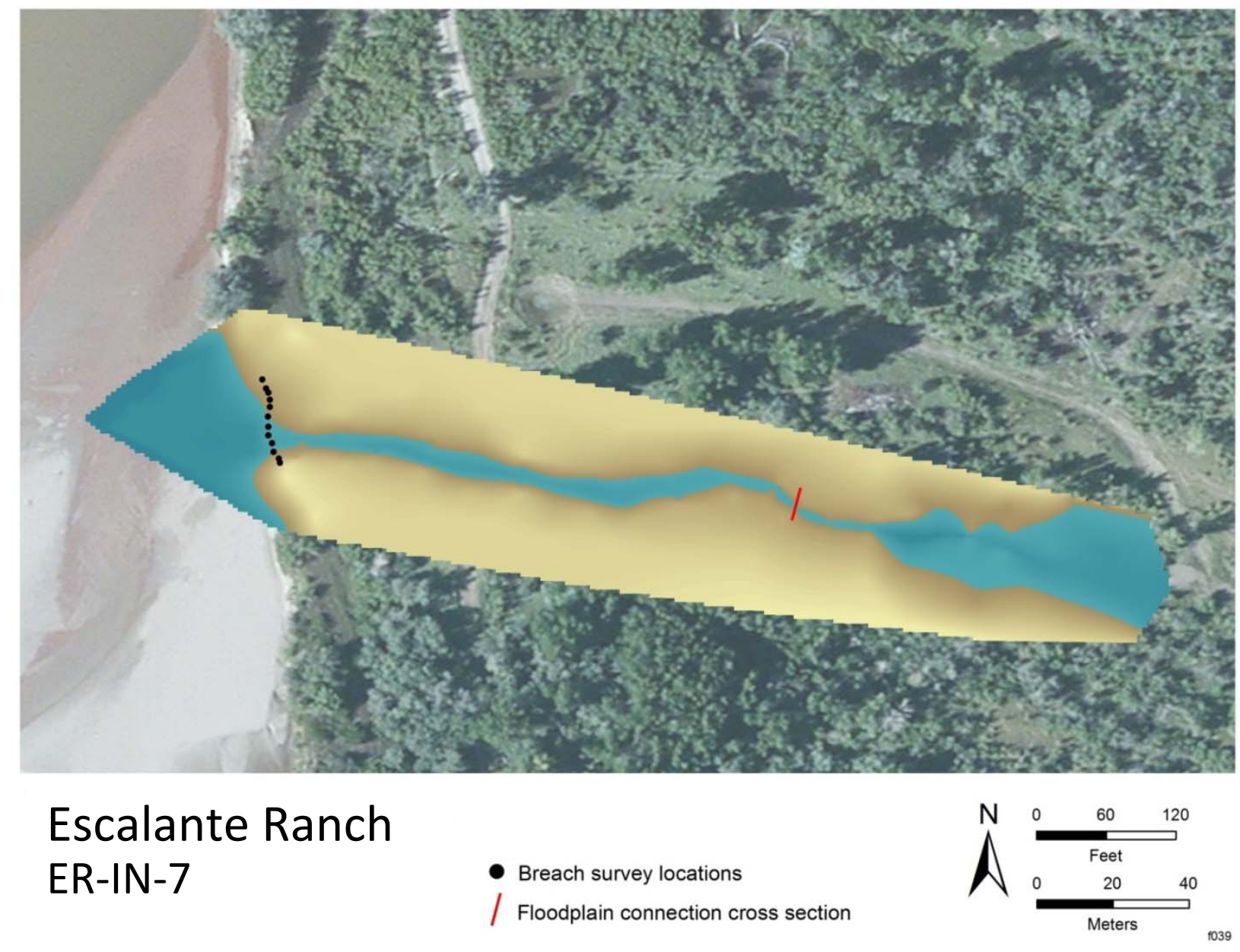

FIGURE B-5 Floodplain Wetland Connection Channel and Minimum Connection Cross Section for ER-IN-7 at 15,300 cfs in 2012 


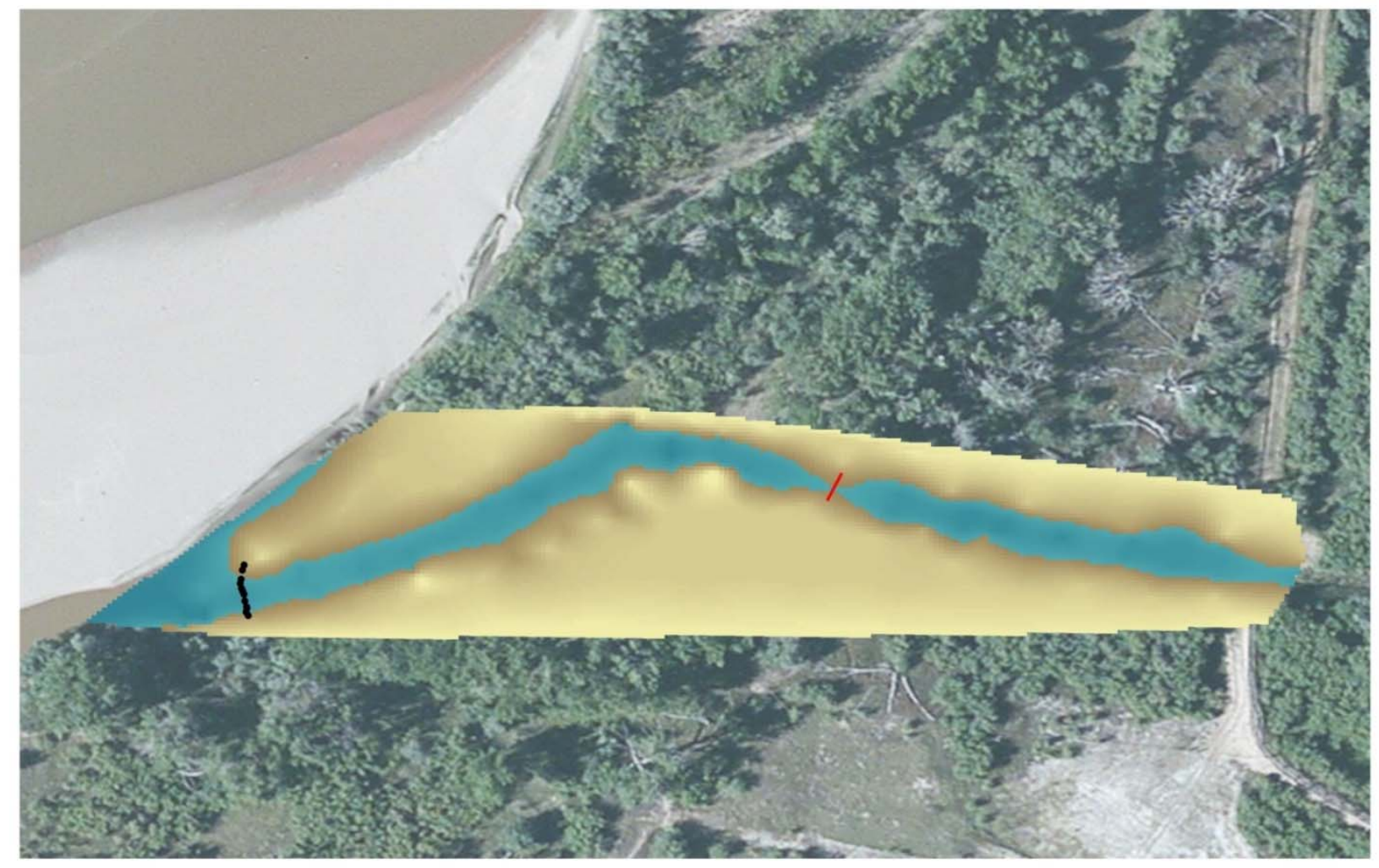

\section{Escalante Ranch ER-OUT}

- Breach survey locations

/ Floodplain connection cross section

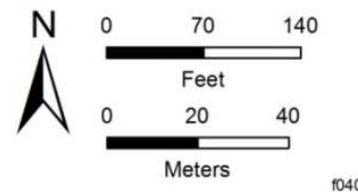

FIGURE B-6 Floodplain Wetland Connection Channel and Minimum Connection Cross Section for ER-OUT at $11,300 \mathrm{cfs}$ in 2012 


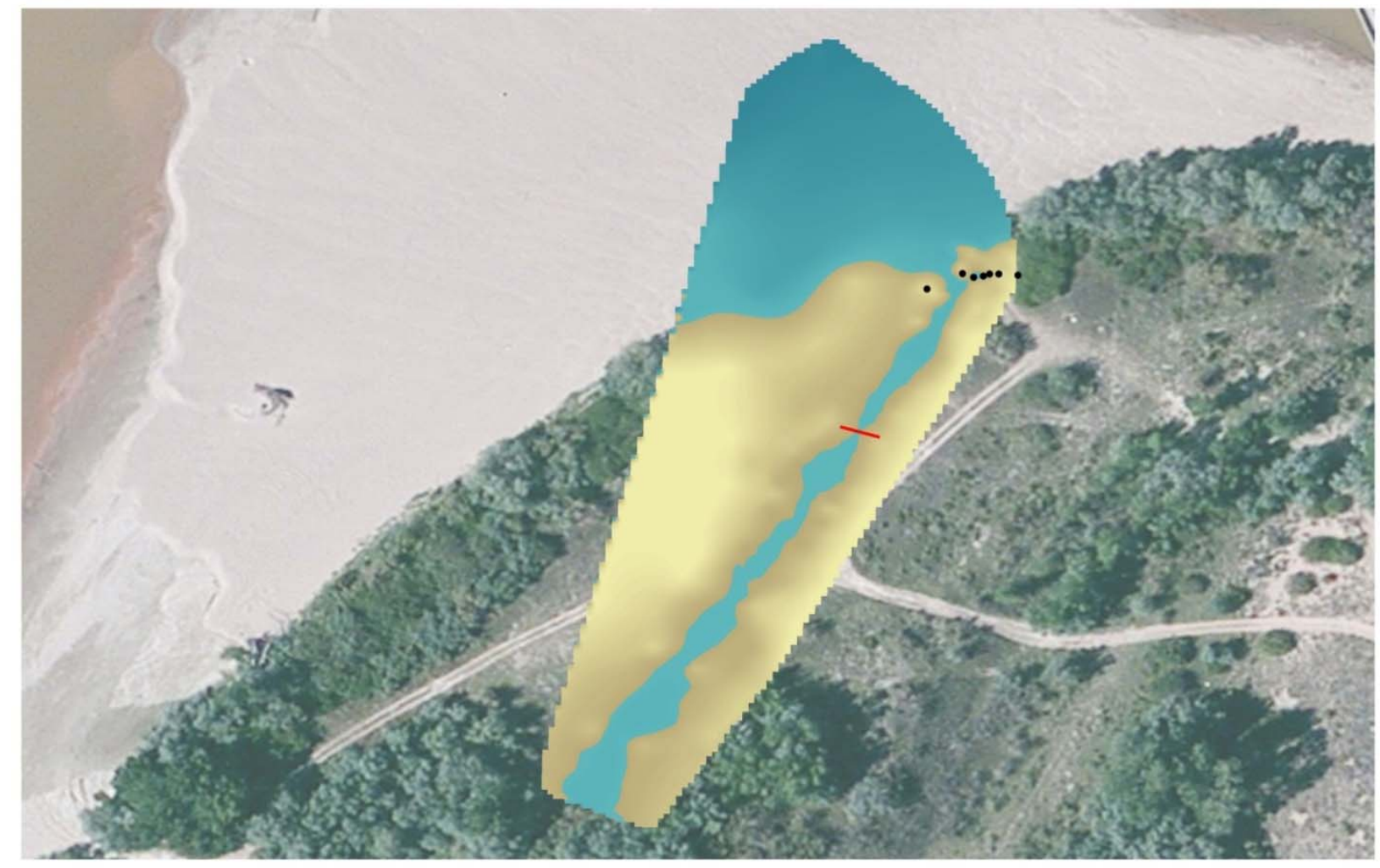

\section{Bonanza Bridge BB-IN-1}

- Breach survey locations

Floodplain connection cross section

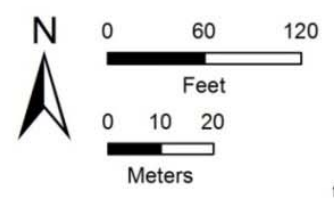

FIGURE B-7 Floodplain Wetland Connection Channel and Minimum Connection Cross Section for BB-IN-1 at 20,100 cfs in 2012 


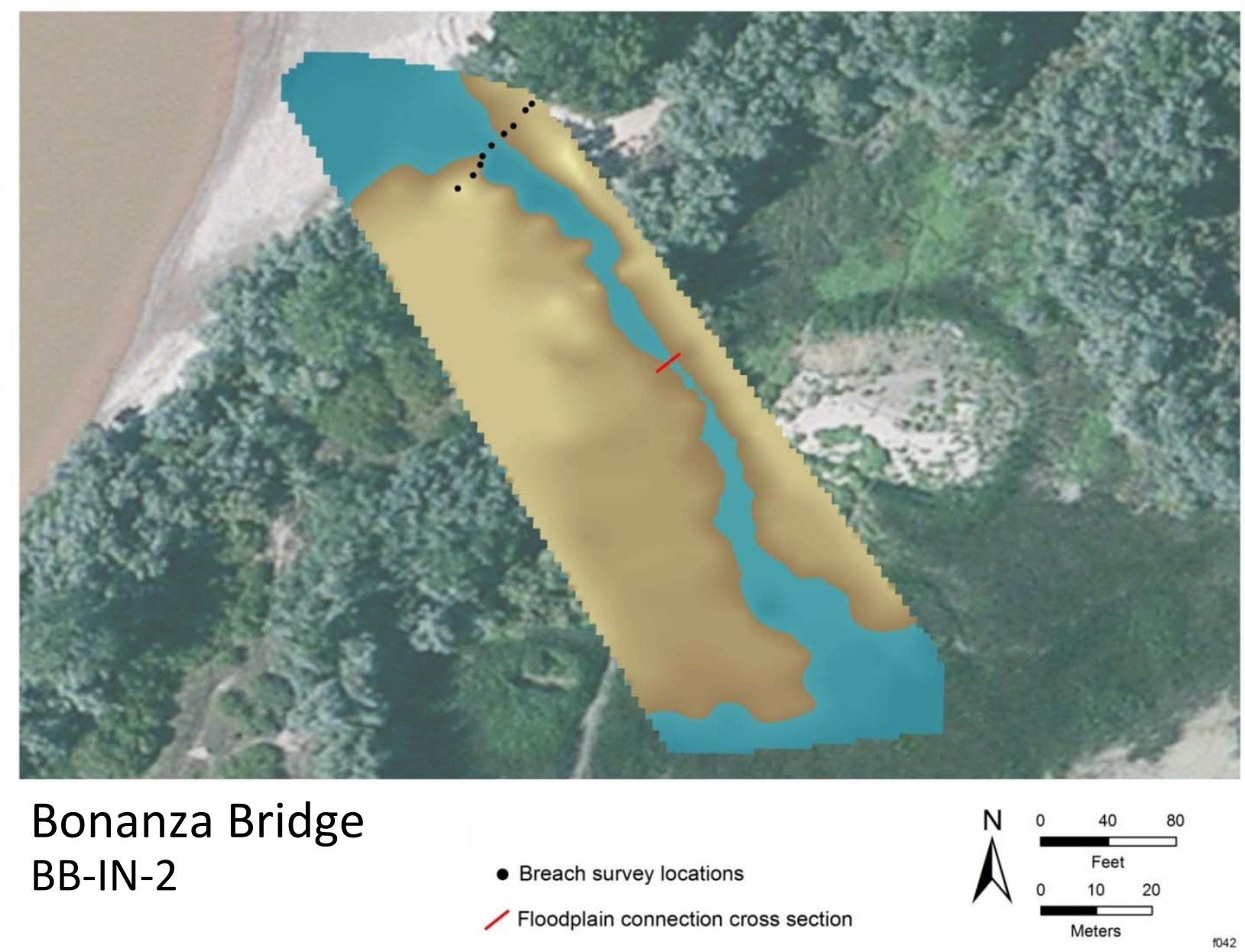

FIGURE B-8 Floodplain Wetland Connection Channel and Minimum Connection Cross Section for BB-IN-2 at 21,100 cfs in 2012 

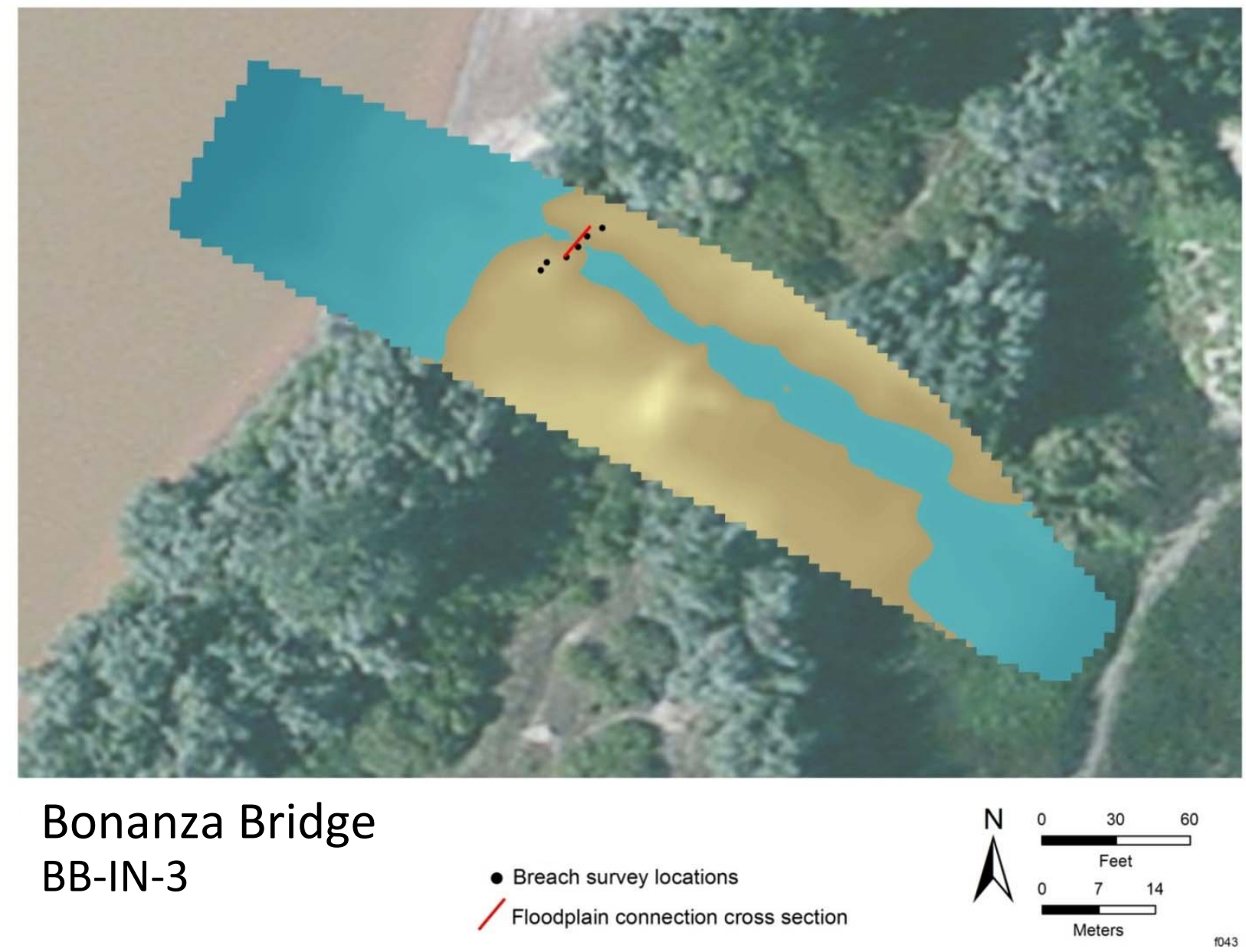

FIGURE B-9 Floodplain Wetland Connection Channel and Minimum Connection Cross Section for BB-IN-3 at 24,100 cfs in 2012 


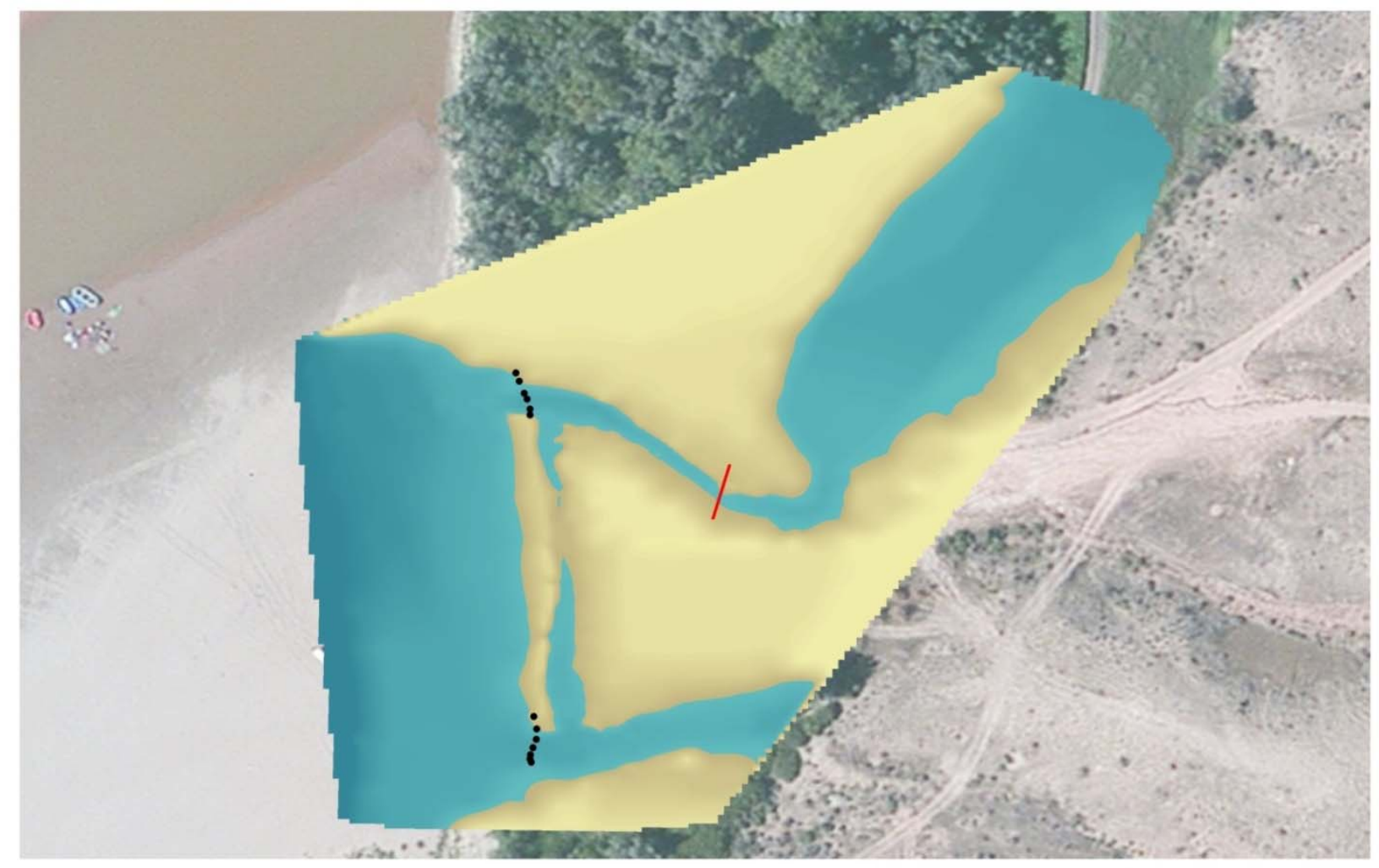

\section{Bonanza Bridge BB-IN-OUT}

- Breach survey locations

/ Floodplain connection cross section

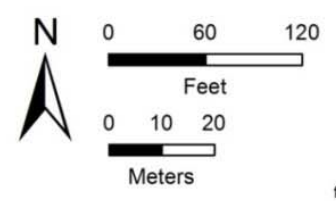

FIGURE B-10 Floodplain Wetland Connection Channel and Minimum Connection Cross Section for BB-OUT at 17,400 cfs in 2012 


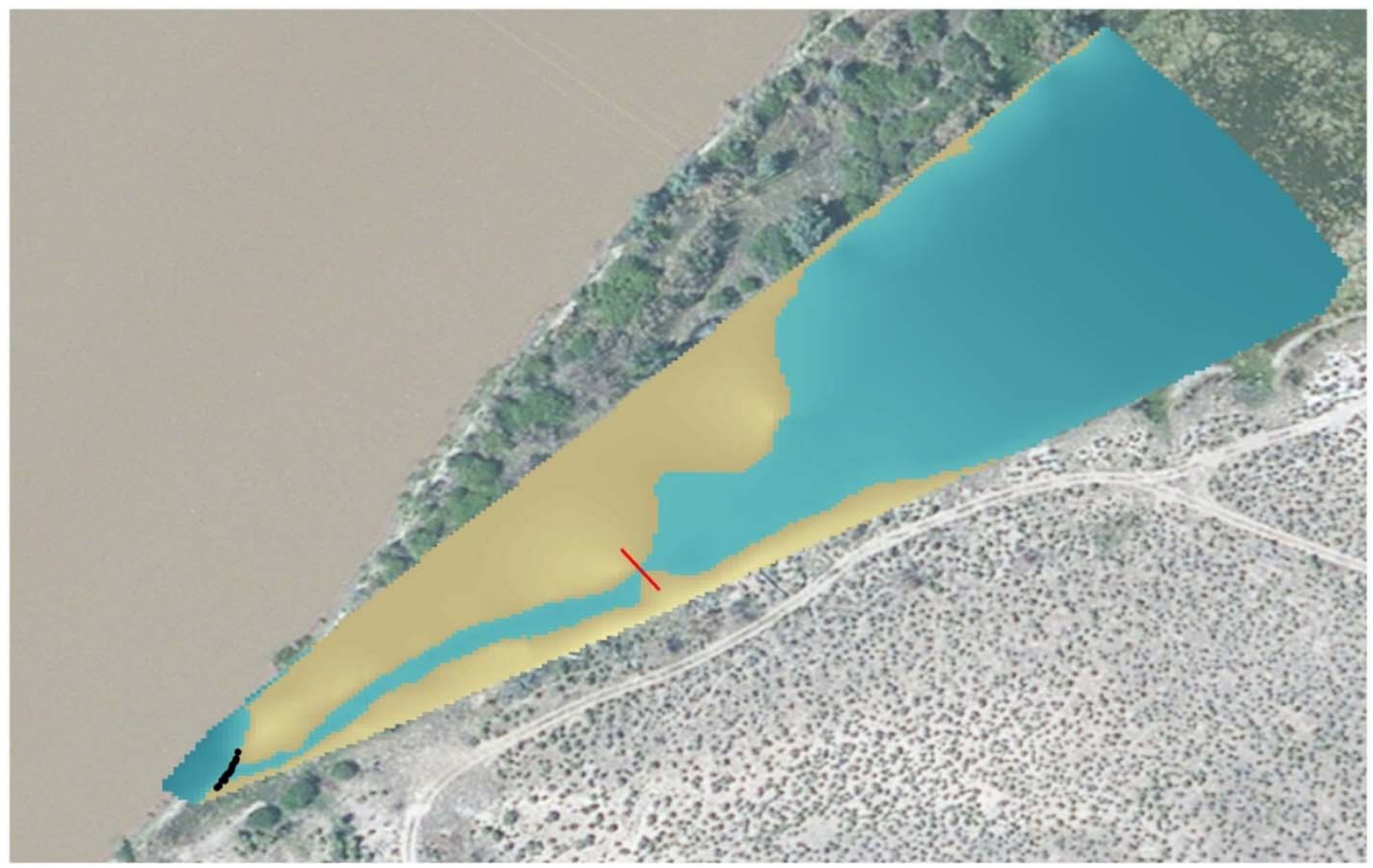

\section{Stirrup ST-OUT}

- Breach survey locations

Floodplain connection cross section

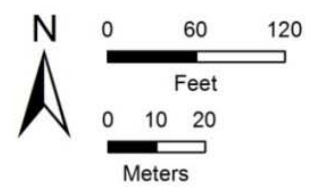

FIGURE B-11 Floodplain Wetland Connection Channel and Minimum Connection Cross Section for ST-OUT at 16,900 cfs in 2012 


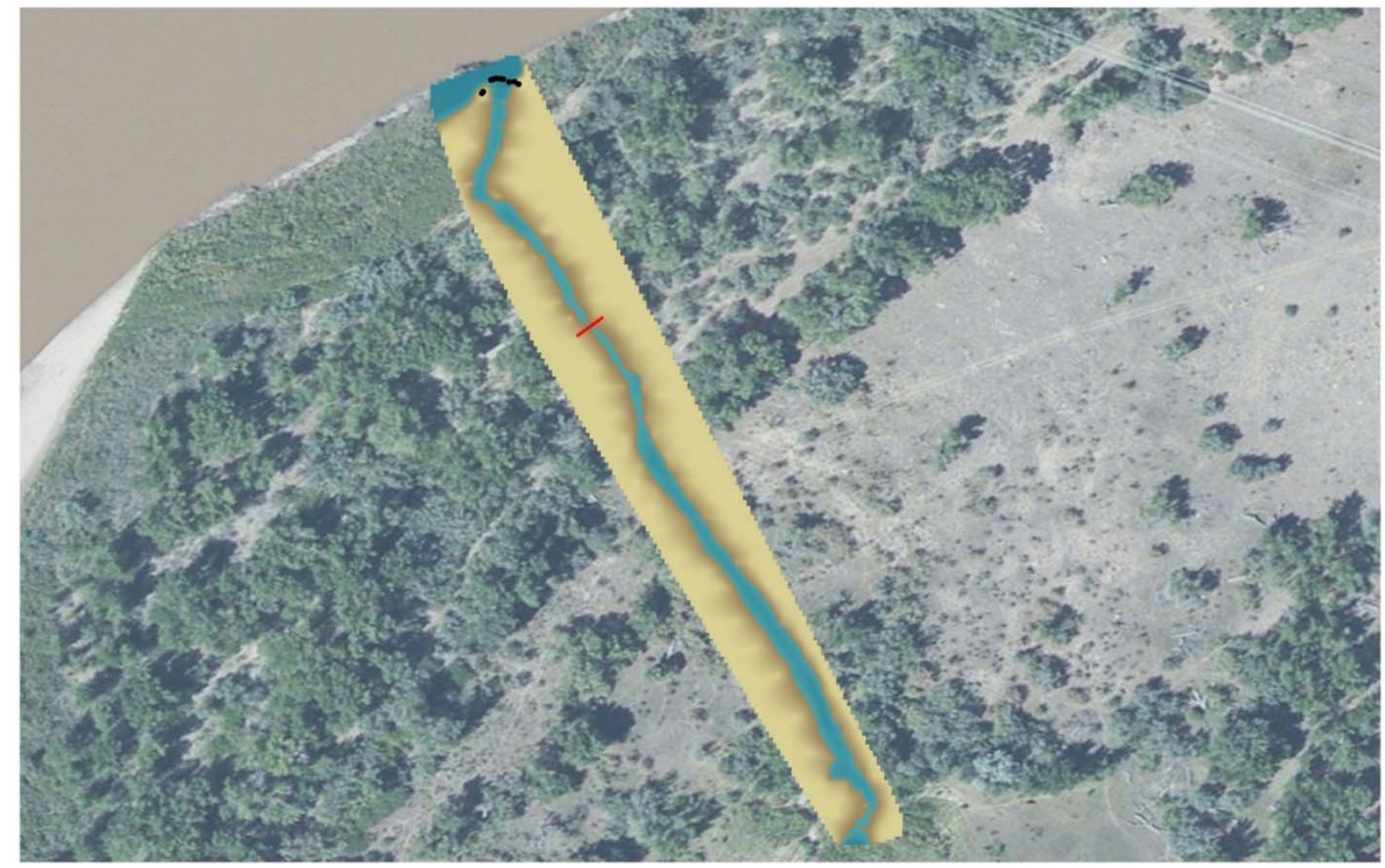

\section{Above Brennan} AB-IN-1
- Breach survey locations

Flooplain connection cross section

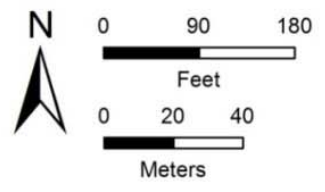

1047

FIGURE B-12 Floodplain Wetland Connection Channel and Minimum Connection Cross Section for AB-IN-1 at 16,400 cfs in 2012 


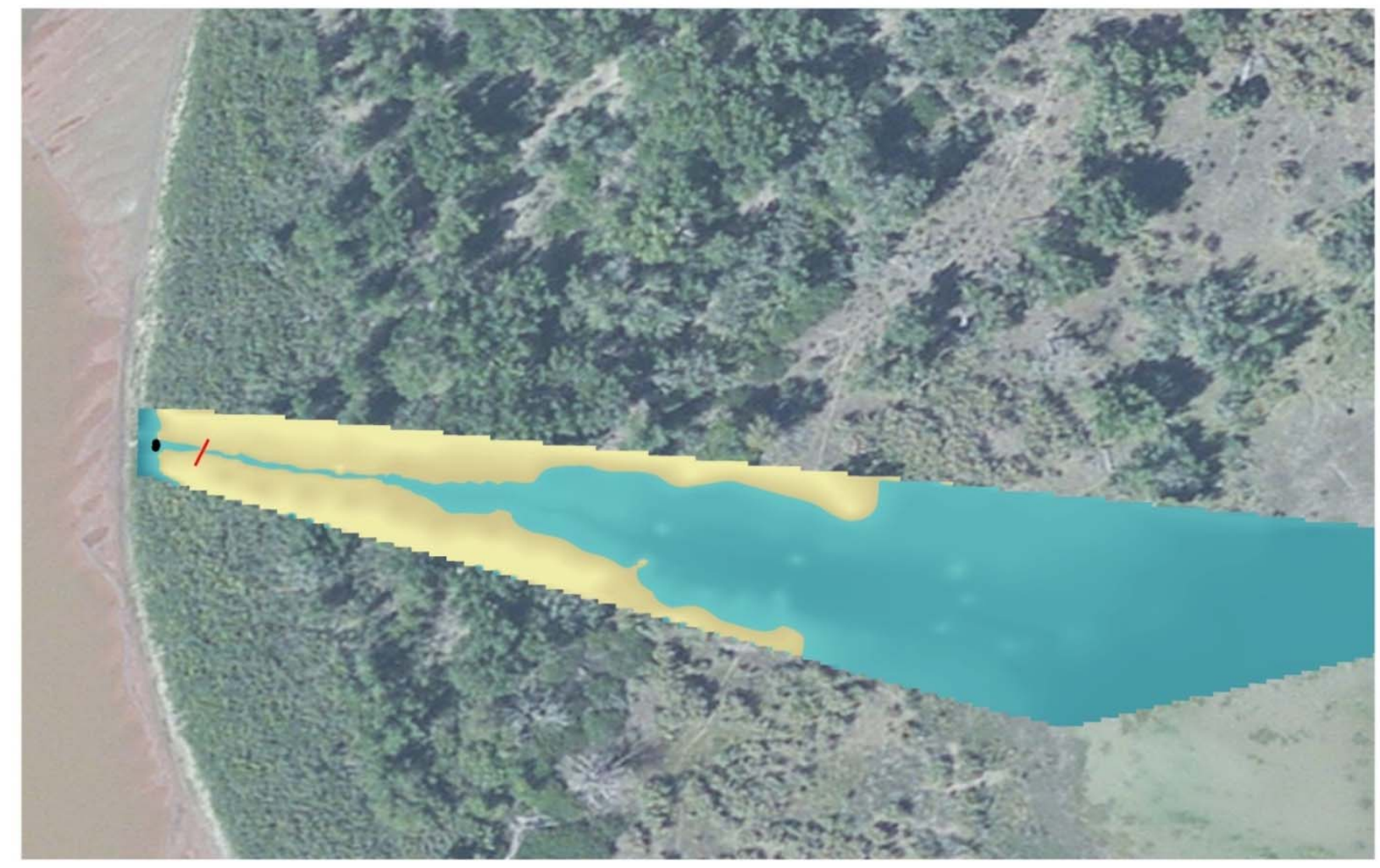

\section{Above Brennan} $A B-I N-2$
- Breach survey locations

/ Floodplain connection cross section

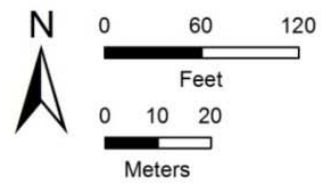

104

FIGURE B-13 Floodplain Wetland Connection Channel and Minimum Connection Cross Section for AB-IN-2 at 19,500 cfs in 2012 


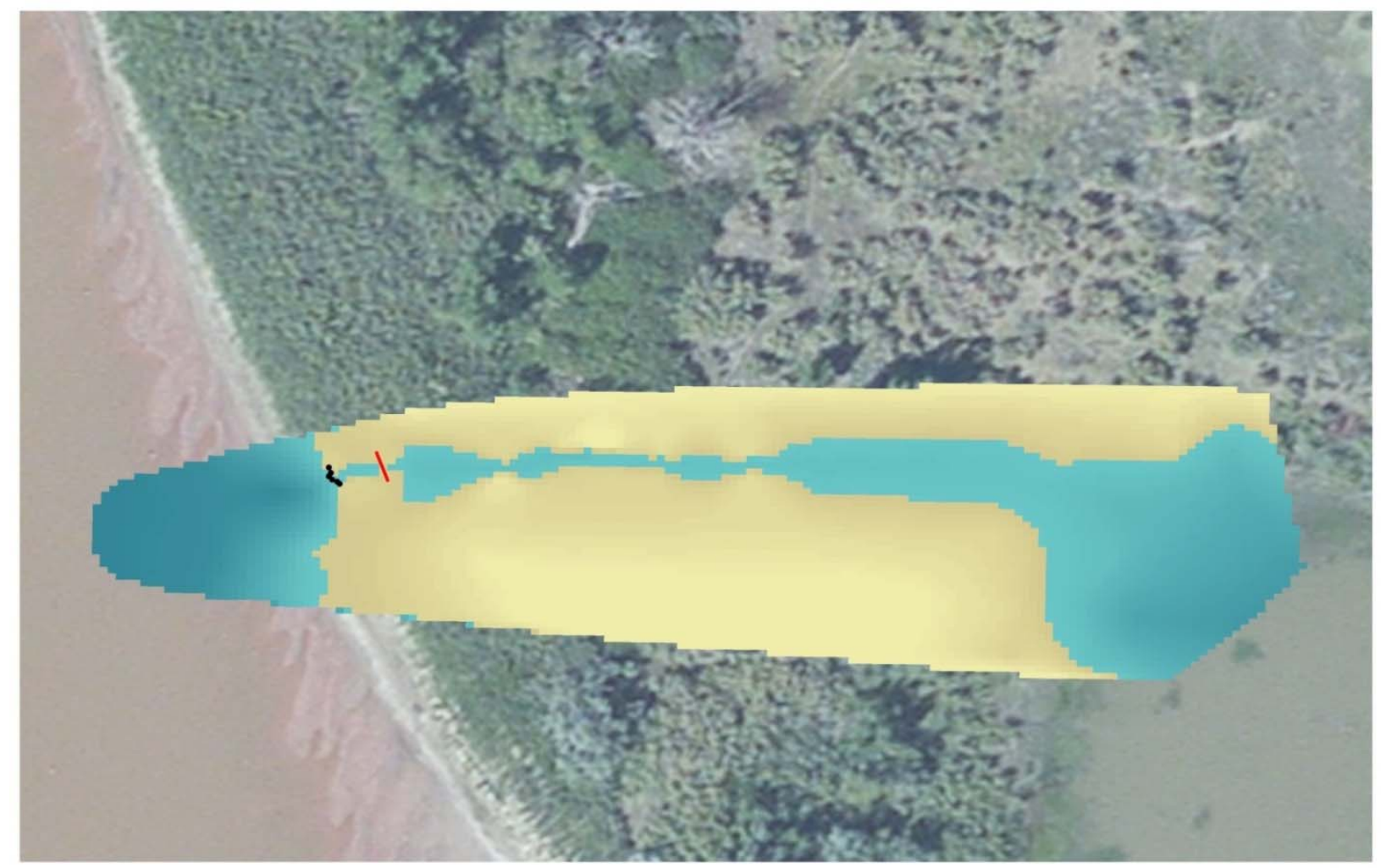

Above Brennan AB-IN-3
- Breach survey locations

$\backslash$ Floodplain connection cross section

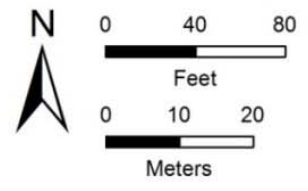

1049

FIGURE B-14 Floodplain Wetland Connection Channel and Minimum Connection Cross Section for $A B-I N-3$ at 18,500 cfs in 2012 


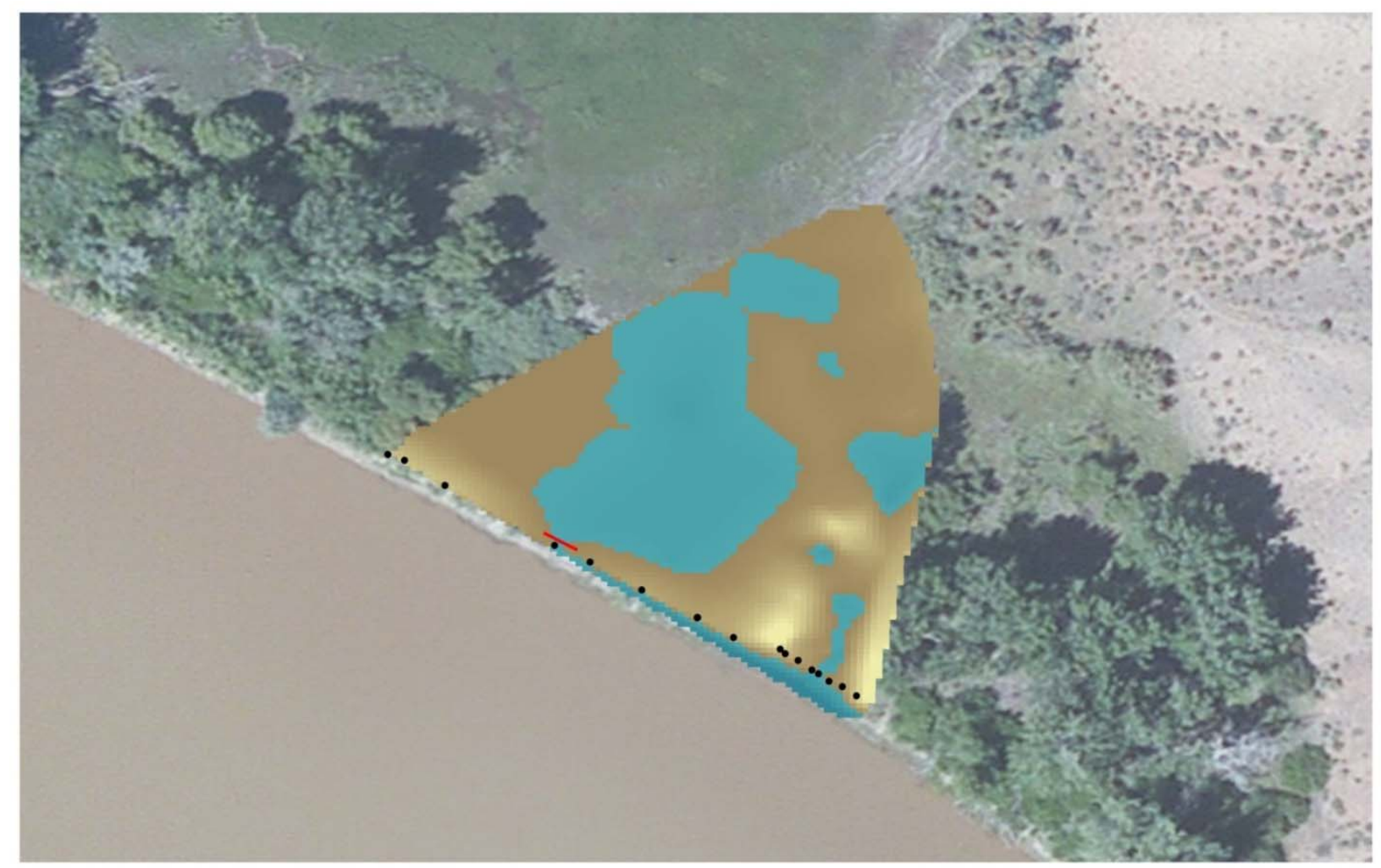

\section{Above Brennan AB-OUT}

- Breach survey locations

$\checkmark$ Floodplain connection cross section

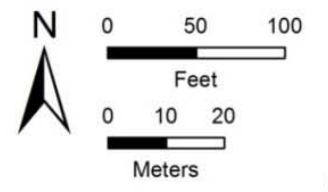

1050

FIGURE B-15 Floodplain Wetland Connection Channel and Minimum Connection Cross Section for $A B-O U T$ at $9,990 \mathrm{cfs}$ in 2012 


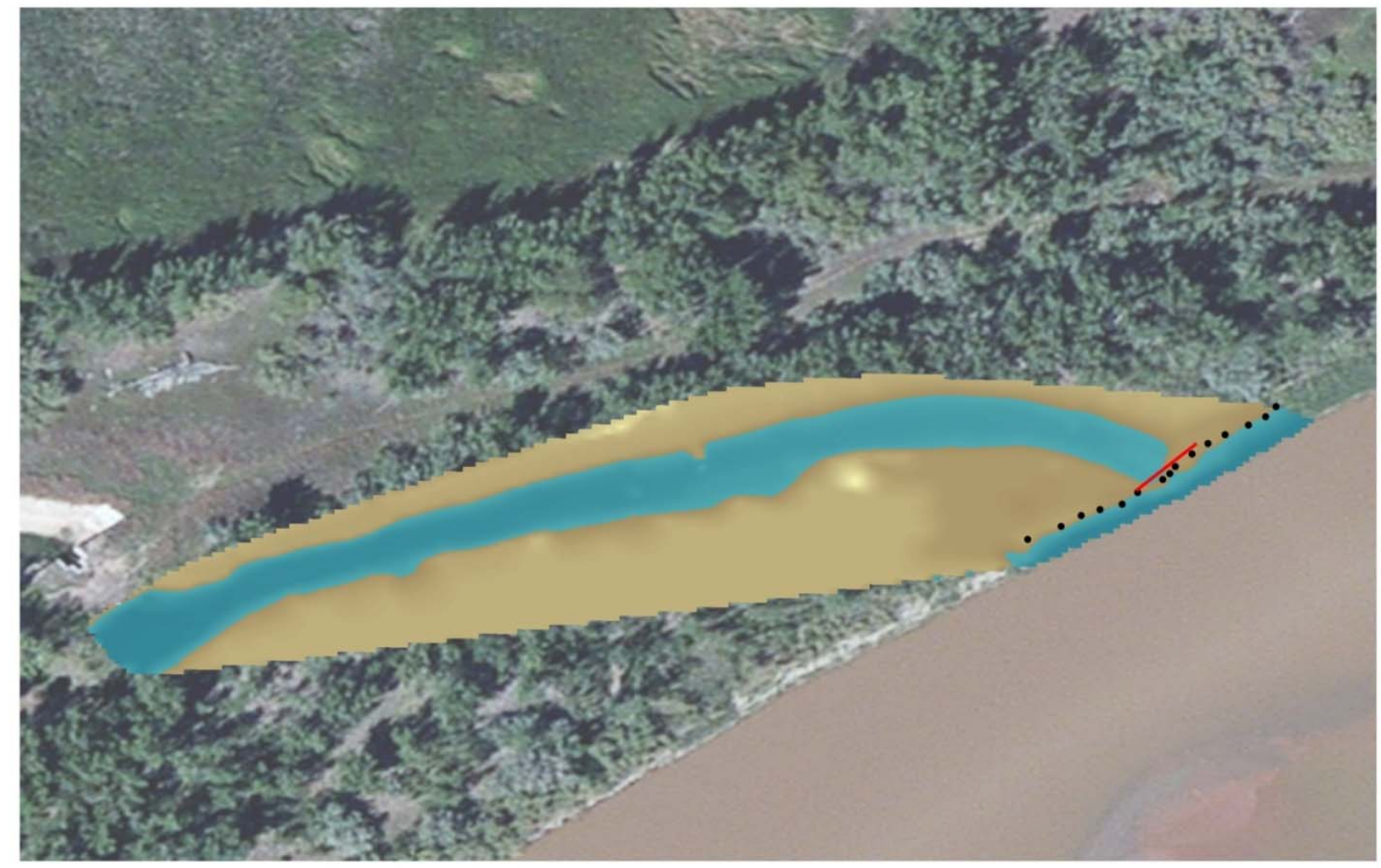

\section{Johnson Bottom JB-OUT-1}

- Breach survey locations

Floodplain connection cross section

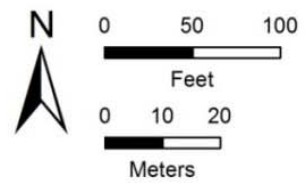

1051

FIGURE B-16 Floodplain Wetland Connection Channel and Minimum Connection Cross Section for JB-OUT-1 at 16,100 cfs in 2012 


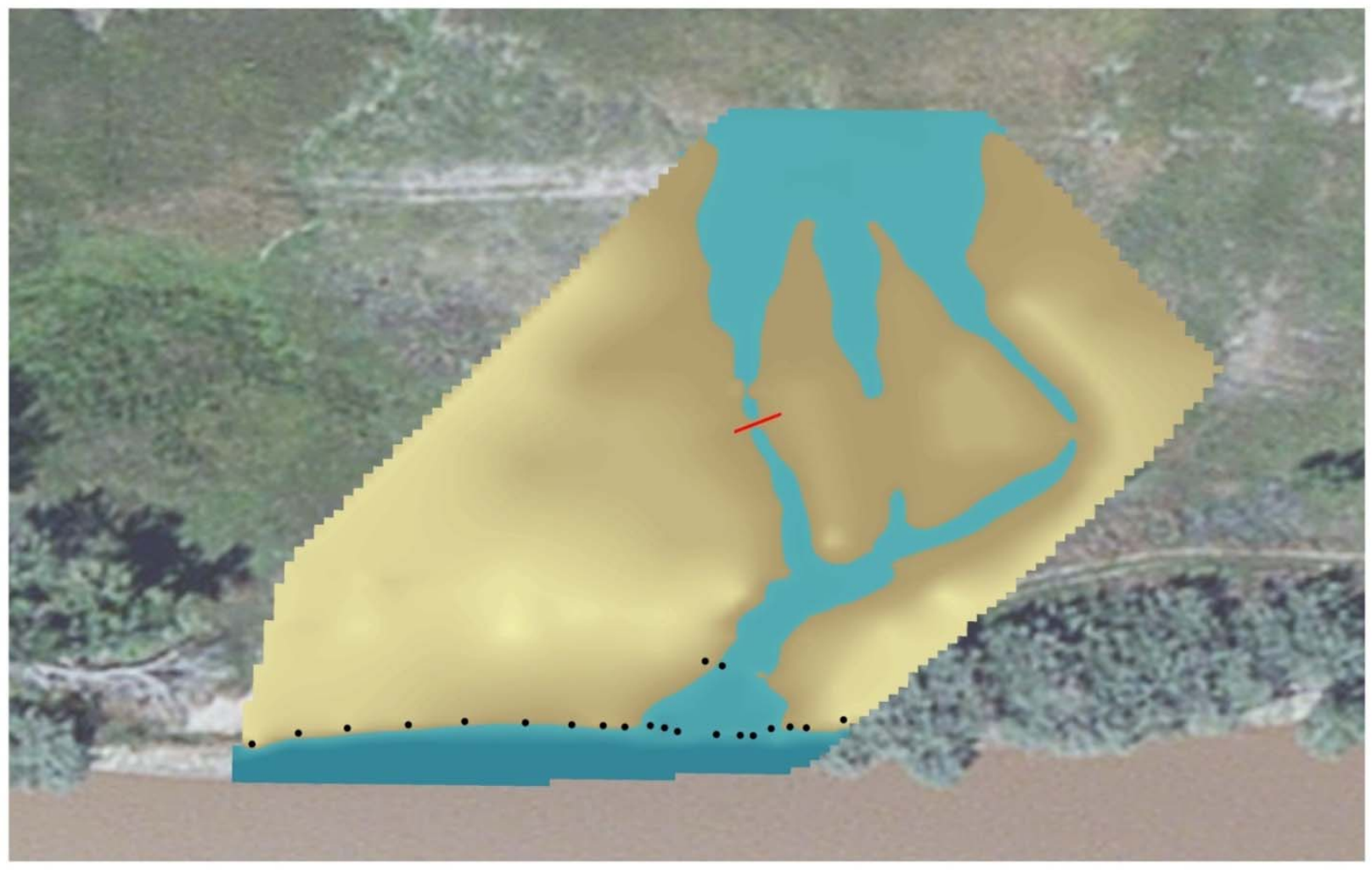

\section{Johnson Bottom JB-OUT-2}

- Breach survey locations

Floodplain connection cross section

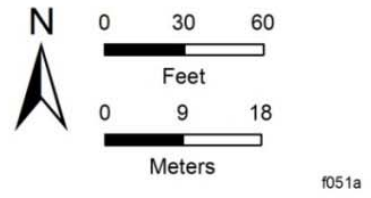

FIGURE B-17 Floodplain Wetland Connection Channel and Minimum Connection Cross Section for JB-OUT-2 at 16,400 cfs in 2012 


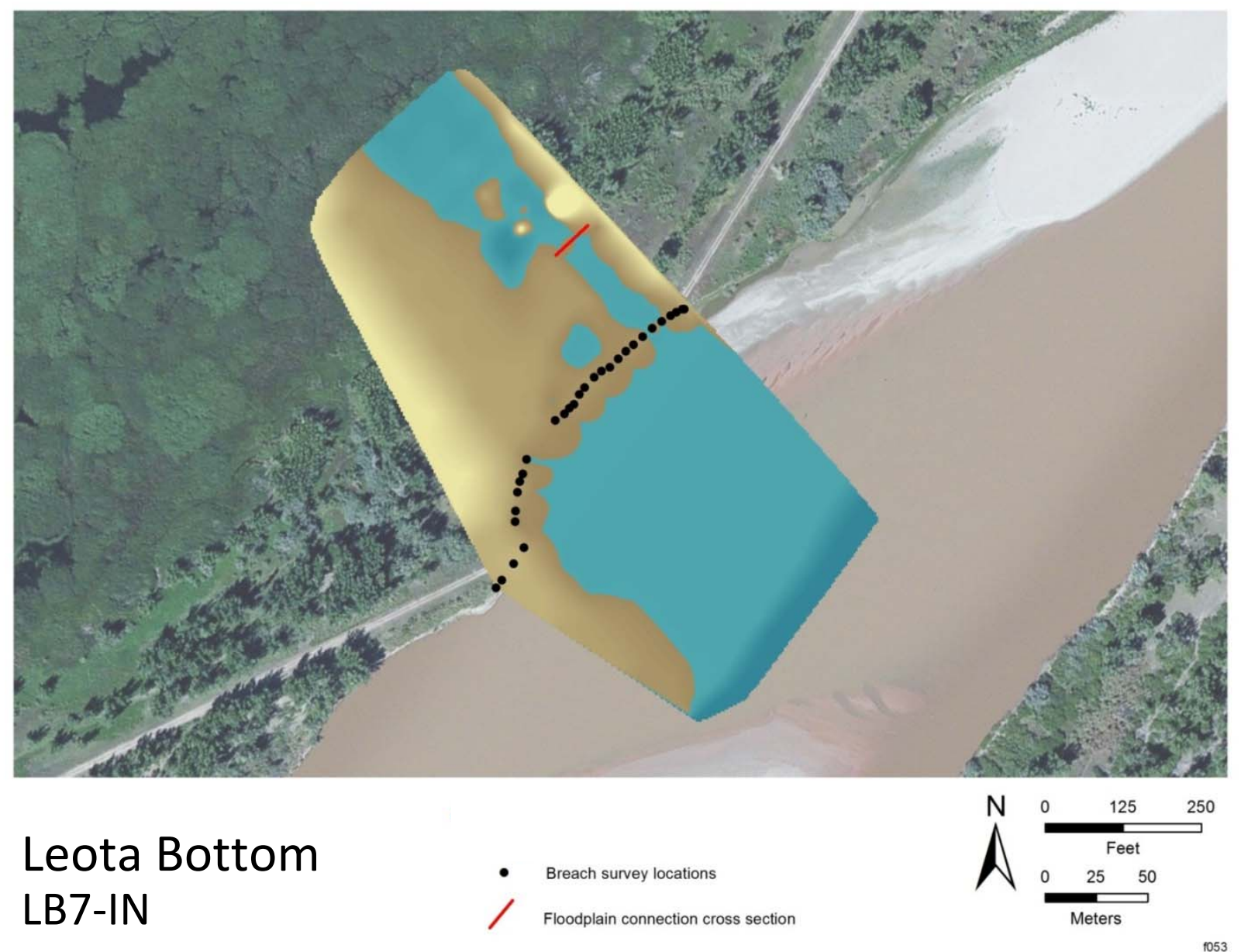

FIGURE B-18 Floodplain Wetland Connection Channel and Minimum Connection Cross Section for LB7-IN at 17,600 cfs in 2012 


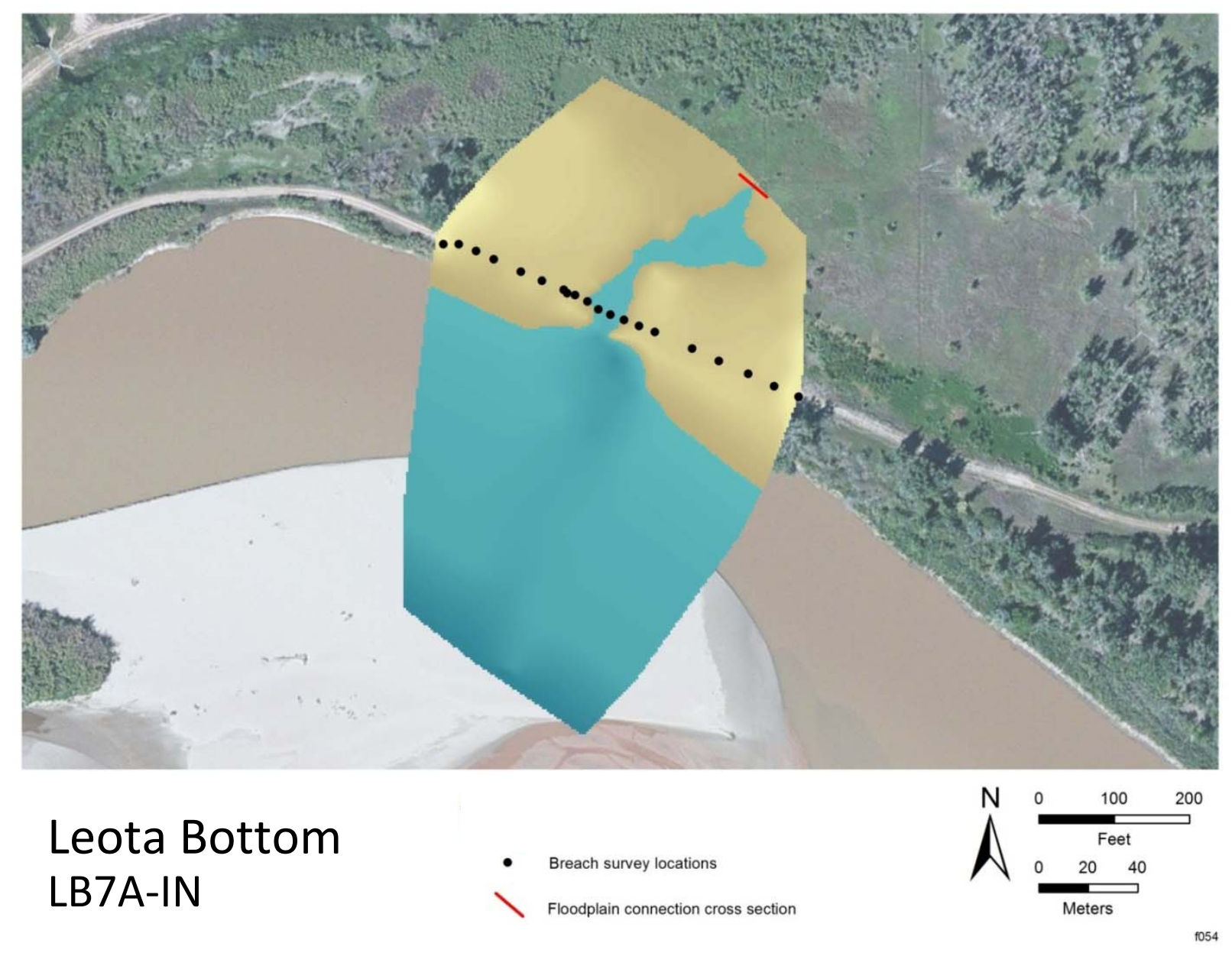

FIGURE B-19 Floodplain Wetland Connection Channel and Minimum Connection Cross Section for LB7A-IN at 13,400 cfs in 2012 


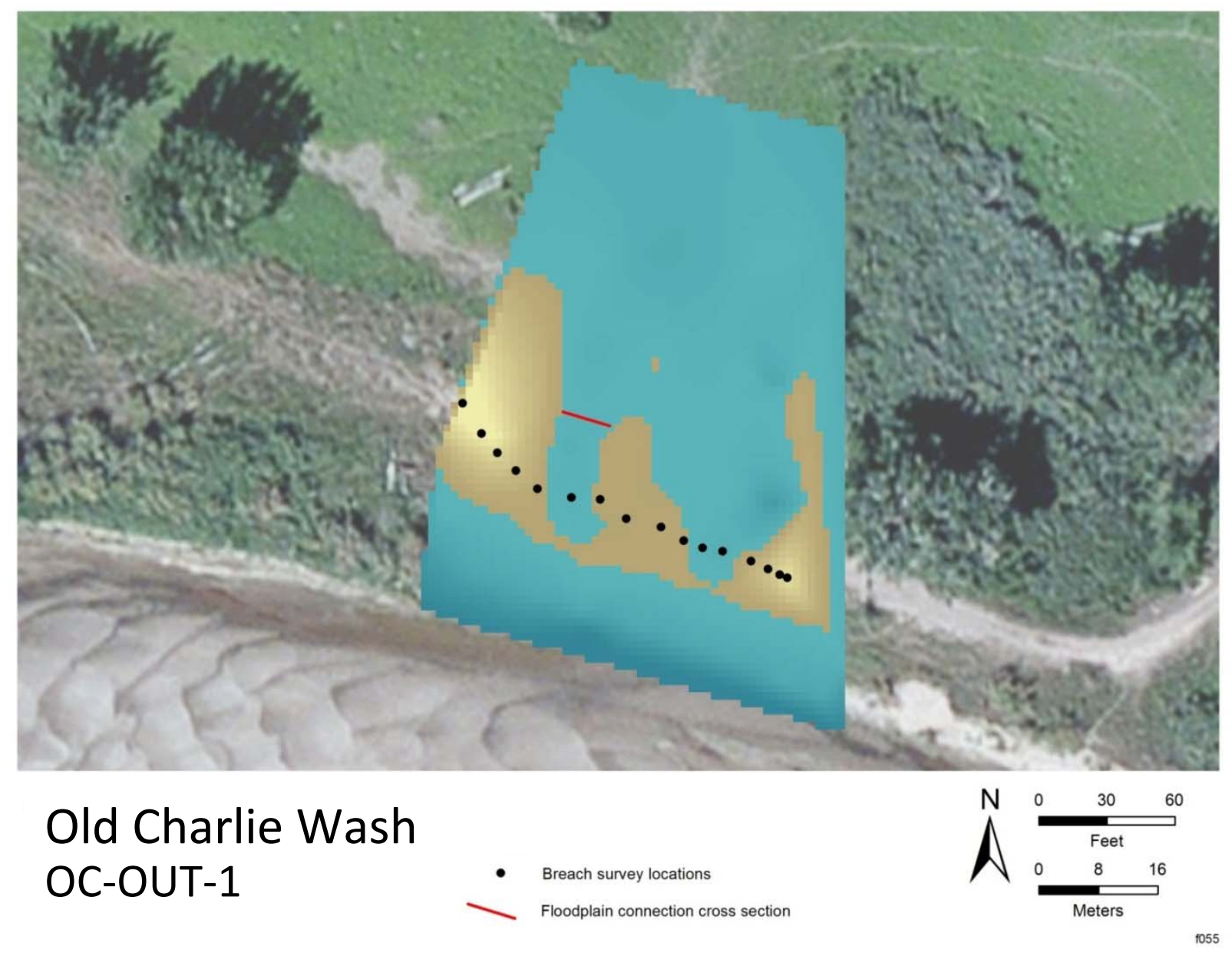

FIGURE B-20 Floodplain Wetland Connection Channel and Minimum Connection Cross Section for OC-OUT-1 at 14,300 cfs in 2012 


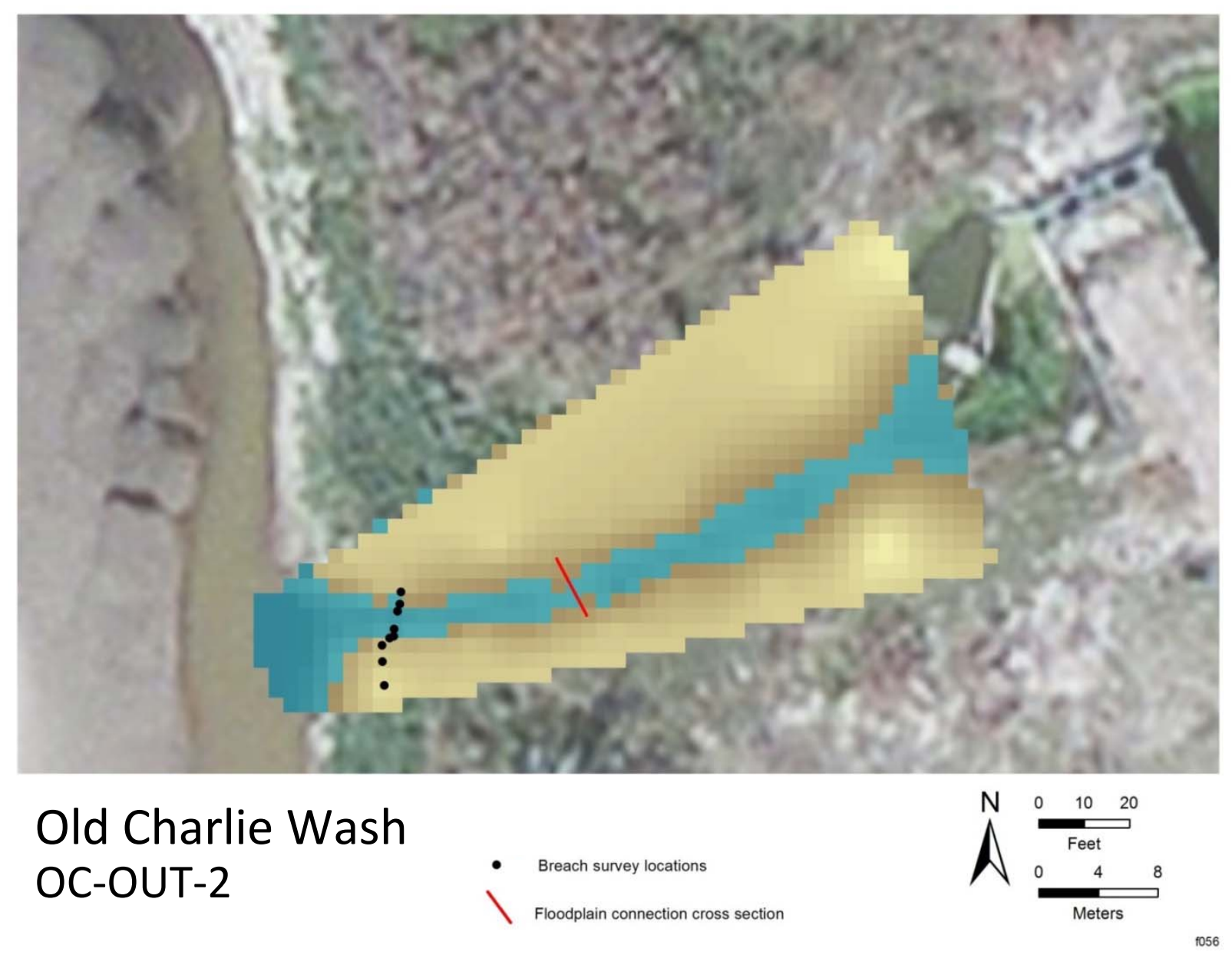

FIGURE B-21 Floodplain Wetland Connection Channel and Minimum Connection Cross Section for OC-OUT-2 at 9,430 cfs in 2012. 


\section{Argonne}

\section{Environmental Science Division}

Argonne National Laboratory

9700 South Cass Avenue, Bldg. 240

Argonne, IL 60439-4847

www.anl.gov 